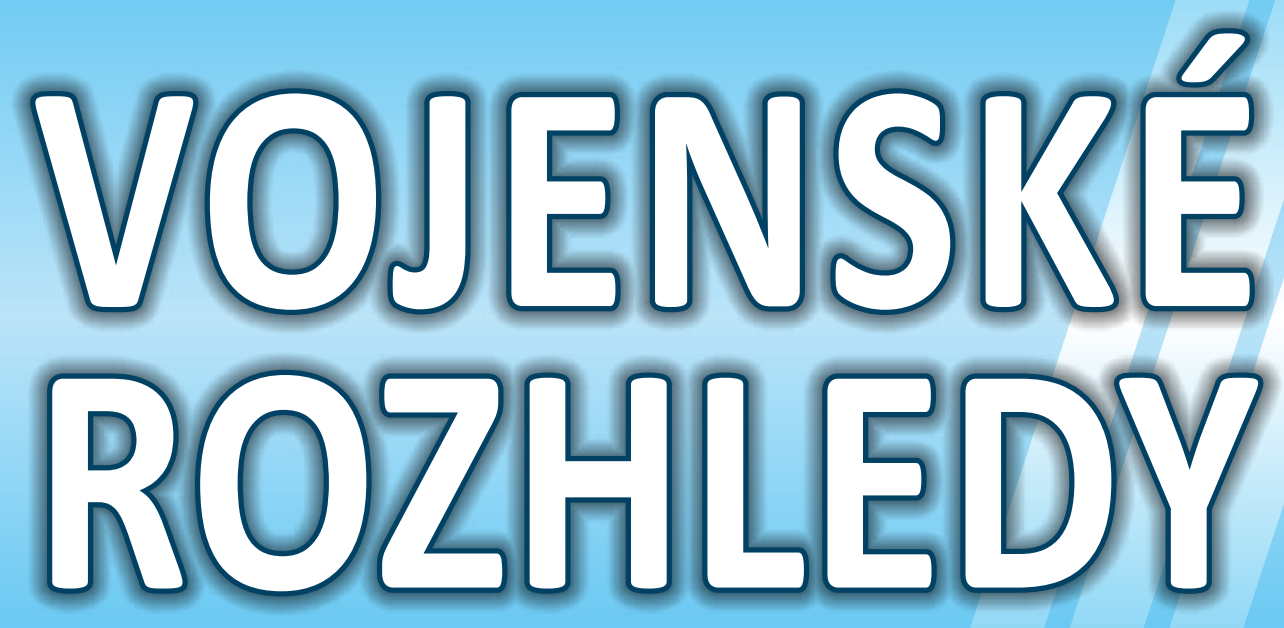

Czesh Mililitarsy Review

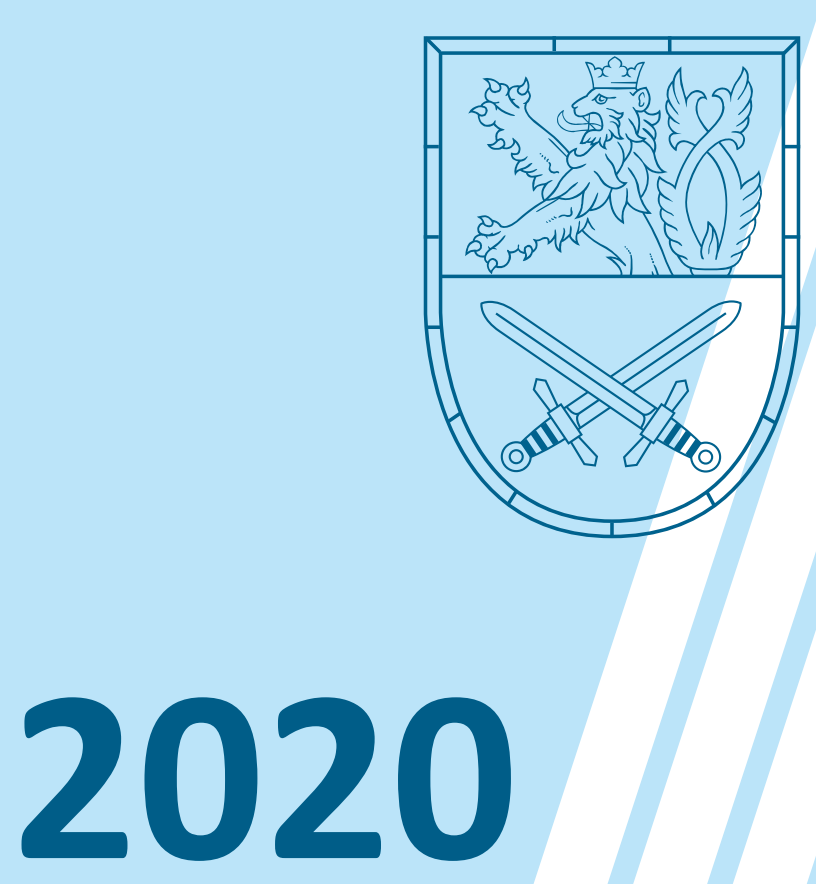




\section{VOJENSKOTEORETICKÝ ČASOPIS}
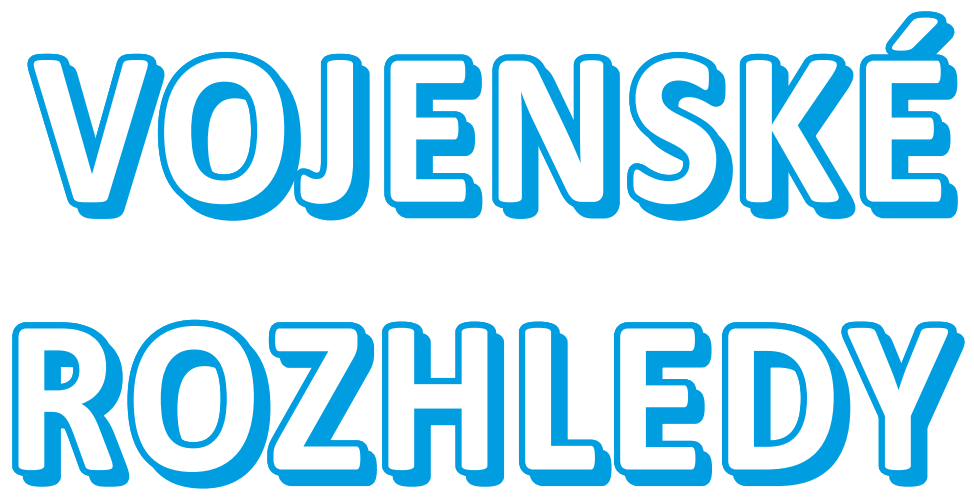

ROČNÍK 29 (61) 



\section{Přistěhovalectví ve Francii a jeho bezpečnostní dopady}

\section{Immigration in France and its security consequences}

\section{Jan Eichler}

Abstrakt: Článek pojednává o přistěhovalectví do Francie a o jeho bezpečnostních dopadech. Začíná historickým kontextem a pak přechází k hodnocení posledních dvaceti let. Zabývá se procesem islamizace a jeho nejvýraznějšími projevy v kulturní, sociální, bezpečnostní a politické rovině. Dále analyzuje vnitrofrancouzskou debatu, ve které se střetávají dva protikladné př́stupy: politická korektnost vs. kritičnost. Tato debata se vede o stanovení počtů přistěhovalců v zemi a především pak o otázce, zda je možné dávat rovnítko mezi přistěhovalectví a nárůst počtu a brutality teroristických útoků (tzv. amalgam). Závěrečná část textu je věnována postavení a úloze přistěhovalců ve francouzských ozbrojených silách. Stat́ jako celek přináší původní periodizaci vývoje přistěhovalectví ve Francii od prvních poválečných let až do současnosti. Hodnotí nejen kvantitativní vývoj tohoto problému, ale také jeho kvalitativní proměny.

Abstract: The article is about the immigration in France and its consequences on the security field. It starts by the historical context and pays a big attention to the development during last two decades. It analyses the process of the islamisation on the cultural, social, security, and political levels. It continues by the French debate which reflects the clash of two contrasting approaches: political correctness vs. critical attitudes. The French experts dispute about two key subjects: the numbers of the immigrants and, namely, the correlations between the immigration and the growing numbers and brutality of the terrorist attacks (the so-called amalgam). The last part analyses the place and the role the immigrants in the French armed forces. This text offers an original periodisation of the phenomena of the immigration in France since the first post WW II years until today. It examines not only its quantitative aspects, but also its qualitative changes.

Klíčová slova: Francie; přistěhovalectví; násilí; konflikty; terorismus; bezpečnost; armáda.

Key words: France; Immigration; Violence; Conflicts; Terrorism; Security; Armed Forces. 


\section{ÚVOD}

Francie je v rámci celé EU zemí s nejdelší tradicí přijímání přistěhovalců, byla přistěhovalcům vždy velice otevřená a přijímala je v několika vlnách. Dnes na svém území má velké množství přistěhovaleckých oblastí, které se nacházejí na okrajích velkých měst, ale dostaly se už do samého centra politické pozornosti. ${ }^{1}$ Její zkušenosti mají celoevropský význam. ${ }^{2}$

V minulém století do Francie přicházeli zejména Belgičané, po nich Italové, Portugalci a Poláci. Ti všichni se nakonec bez problémů nejprve integrovali a posléze i asimilovali. Integrace ve francouzském pojetí znamená, že přistěhovalci přijmou všechna pravidla a zásady společnosti, do které přišli, ale mohou si uchovat své vlastní charakteristiky, včetně krajanských sdružení. O pojmu asimilace se ve Francii vedou rozsáhlé a v podstatě nekončíi debaty. Podle sociologů se jedná o sociální proces konvergence chování lidí, kteři přicházejí do jiné země. Zdrcující většina Francouzů (94\%) přitom očekává, 3 že ti, kdo přicházejí do jejich země, se přizpůsobí francouzskému životnímu způsobu. ${ }^{4}$ Zároveň $s$ tím je asimilace považována za vyšší stupeň, ${ }^{5}$ na němž se přistěhovalci v nové společnosti zcela rozplynou a stanou se její součástí. ${ }^{6}$

O masovém pozvání přistěhovalců ze severní Afriky začal jako první hovořit už Charles de Gaulle, ${ }^{7}$ a to hned v březnu 1945, protože si byl vědom, že nebylo v silách jeho země napravit těžké válečné škody v průmyslu, zemědělství a infrastruktuře, zvláště když země měla přes 600 tisíc obětí na životech, a to převážně mužů. ${ }^{8}$ Jeho vláda se rozhodla, že na pomoc národnímu hospodářství pozve desítky tisíc mužů ze severní Afriky, a těm se začalo říkat „pozvaní pracující.“ 9 Počítalo se, že se po několika letech budou vracet domů. Nejsilnější vlna přišla na samém počátku 60. let, kdy do Francie proudilo až 70000 přistěhovalců týdně. ${ }^{10}$ Jenomže vše skončilo zcela jinak, než jak si francouzští ekonomové a politici představovali. Alžírané, Maročané, Tunisané a další se domů nevrátili, naopak do Francie začali zvát své rodiny a další příbuzné. ${ }^{11}$ Ve Francii tak začala vznikat

1 Boniface, Pascal: Comprendre le monde: les relations internationales expliquées à tous. Malakoff: Armand Colin, 2019, s. 231-239.

2 Gomart, Thomas: L' Affolement du monde: 10 enjeux géopolitiques. Paris: Tallandier, 2019, s. 258-260.

3 "Rapport Racisme 2011 CNCDH » La lutte contre le racisme, I' antisémitisme et la xénophobie.

4 Michèle Tribalat, Assimilation : La fin du modèle français, Paris, Éditions de Toucan, 2013

5 Wihtol de Wenden, Catherine: Géopolitique des migrations: 40 fiches illustrées pour comprendre le monde, Paris: Eyrolles, 2019, s. 66.

6 Michèle Tribalat: Assimilation: La fin du modèle français. Paris, Éditions de Toucan, 2013.

7 Funkci premiéra, v té době hlavy státu, zastával od 3. 6. 1944-20. 1. 1946.

8 La deuxième guerre mondiale en Première - Les morts de la ... www.cndp.fr > ... > La $2^{\circ} G M$ en Première.

9 Weil, Patrick: La France et ses étrangers; L'aventure d'une politique d'immigration, 1938-1991. Paris, Calmann-Lévy, 1991, s. 68-69.

10 L'Institut national de la statistique et des études économiques, Insee, Première, n. 1098, aout 2006.

11 La France, un vieux pays d'immigration | Ihistoire.fr www.lhistoire.fr , la-france-un-vieux-pays-dimmigration. 
přistěhovalecká komunita, která je stále početnější a dnes čítá dnes již několik milionů lidí - další části textu ukáží, že o jejich přesném počtu se vedou nekonečné a také hodně vyrocené diskuse.

\section{METODOLOGICKÁ VÝCHODISKA}

Z hlediska metodologického se tento text pohybuje na rozhraní dvou typů textů, kterými jsou policy - evaluative a historical explanatory. ${ }^{12}$ Konkrétně to znamená, že text se zaměřuje na hodnocení politických programů, řešení a postupů vztahujících se k problematice přistěhovalectví ve Francii. Hledá odpověd' na otázku, zda tyto politiky vedly k takovým výsledkům, jaké slibovali jednotliví politikové. Nedílně s tím se text snaží vysvětlit přičiny historického vývoje tohoto problému během posledních dvou desetiletí, kdy se v čele země vystřídali čtyři prezidenti ${ }^{13}$, a zabývá se fungováním a důsledky dosavadních přístupů a koncepcí. ${ }^{14}$ Text je napsán historickou metodou, vysvětluje vývoj přistěhovalectví do Francie od prvních poválečných let až do současnosti. V tomto rámci stat́ přináší původní periodizaci poválečného přistěhovalectví do Francie, která dává do souvislostí tři vzájemně propojené fenomény: př́liv lidí ze severní Afriky, reakce politiků a odborné debaty o přistěhovalectví a o jeho dopadech na budoucnost země. Tato periodizace ukazuje, jak se měnily nejen kvantitativní, ale především kvalitativní parametry tohoto kontroverzního fenoménu.

\section{OD PRVNÍCH NO GO ZONES PO VYPUKNUTÍ GERILOVÉHO NÁSILÍ VE VELKÝCH MĚSTECH}

Již v polovině 70. let začaly ve Francii vznikat první oblasti, ve kterých se rychle hromadily sociální nerovnosti a přestávaly $v$ nich platit francouzské zákony. Těmto oblastem se říká „non - droit“ (ne - právo), což znamená, že v nich neplatí právo dané země, ale zákony tamních gangů a jejich samozvaných vůdců. První z nich se stala obec Chanteloup - les - Vignes, 30 km na sever od Paříže, která původně měla pouhých 2000 obyvatel, ale v roce 1975 tam tehdejší president Valéry Giscard d'Estaing ${ }^{15}$ otevíral nové železobetonové sídliště pro 20000 obyvatel, přičemž všichni z nich byli přistěhovalci. Tamní ulice byly pojmenovány podle významných francouzských básníků, ale synové přistěhovalců je

12 Van Evera, Stephen: Guide to methods for students of political science. Ithaca: Cornell University, 1997.

13 Byli jimi: Jacques Chirac (1995-2007), Nicolas Sarkozy (2007-2012), Francois Hollande (2012-2017) a Emmanuel Macron (2017- současnost).

14 V tomto prípadě je typické, že každý francouzský prezident měl svůj osobitý přístup, svoji vlastní koncepci.

15 Funkci zastával v letech 1974-1981, předtím byl ministrem financí. 
hned přejmenovali podle svého, např. „Prostor pro šelmy“, „Dostižiště“ a podobně. Celý prostor si mezi sebou rozdělily gangy mladých násilníků, kteří začali terorizovat celé sídliště. ${ }^{16}$ Později byl o této „adrese“ natočen film Nenávist, který v plné nahotě ukázal tamní násilí, včetně ozbrojených útoků na policisty. ${ }^{17}$ Byl natočen tak působivě, že tehdejší premiér Alain Juppé ${ }^{18}$ nařídil všem ministrům, aby jej shlédli, ${ }^{19}$ přičemž hlavní důraz se položil na oboustrannou brutalitu. ${ }^{20}$

Oblast Chanteloup - les - Vignes se velmi rychle stala inspirací pro chuligánské party po celé Francii. K velkému výbuchu jejich řádění došlo v listopadu 2005, kdy hořely stovky aut a obchodů na severních předměstích Paříže. ${ }^{21}$ Tento vývoj silně umocňuje obavy z budoucnosti,22 především proto, že počet mladých obyvatel $v$ těchto velice problémových čtvrtích velmi rychle narůstá, a tak se tam i hromadí napětí, které se pak stále častěji ventiluje násilím. ${ }^{23} Z$ těchto čtvrtí se posléze stávají ghetta, přičemž mladí islamisté se v nich uzavírají sami ze svého vlastního přesvědčení. ${ }^{24} \mathrm{~V}$ nich pak vytvářejí tzv. kriminogenní infrastrukturu, ${ }^{25}$ což je výstižný výraz, se kterým přišel Pierre Cardo, dlouholetý starosta (1993 - 2010) výše vzpomínaného problémového města Chanteloup-les-Vignes. ${ }^{26}$ Přitom se ukazuje, že druhá generace těchto mladých násilníků je horší, nežli byla ta první a třetí je ještě horší, než byla ta druhá. ${ }^{27}$

\section{SOUČASNÁ SITUACE}

Pokud jde o současný podíl přistěhovalců z islámského světa na celkovém počtu všech obyvatel Francie, neexistují žádné přesné údaje, na kterých by se všichni shodli.

16 Christophe Dubois: Des groupes de combattants se constituent en France. Le Parisien, 19. 9. 2005.

17 "La Haine», Cahiers du Cinéma, juin 1995, s. 32-35.

18 Jeden z matadorů francouzské politiky, dlouholetý starost města Bordeaux (2006 -2019), ministr zahraničí, ministr obrany, funkci premiéra zastával v době od 17. 5. 1995 do 2.6. 1997, když prezidentem byl Jacques Chirac.

19 Quinze ans après La Haine : l'important ce n'est toujours pas la chute, c'est l'atterrissage [archive], Julien Bordier, Variations, 2011.

20 "Why the prime minister had to see La Haine», The Independent, \19 octobre 1995.

21 Raphaël Draï et Jean-François Mattéi (dir.): La république brûle-t-elle ? Essai sur les violences urbaines françaises [archive]. Éd. Michalon, 2006.

22 Jean de Maillard: Dans les banlieues, le pire reste à venir. Le Nouvel Observateur, 22. 11. 2016.

23 Raphaël Draï et Jean-François Mattéi (dir.) : La république brûle-t-elle ?: Essai sur les violences urbaines françaises [archive]. Éd. Michalon, 2006

24 Ian Johnson: Islam and Europe: a Volatile Mix. Wall Street Journal, 11. 7. 2005.

25 Deux maires courage; dialogue sur la crise des banlieues» [archive], avec Claude Dizain, maire de Clichy-sous-Bois (93), Ed. Autrement, 2008.

26 Chanteloup-les-Vignes: Pierre Cardo quitte la vie politique » [archive], sur versailles.cci.fr, 10 décembre 2012.

27 Christopher Caldwell: Une révolution sous nos yeux, préface de Michèle Tribalat, Traduction de l'anglais de Johan Frederik Hel Guedj, édition du Toucan, collection Adultes. Paris 2010, s. 187. 
Dostupné jsou pouze odhady, a ty se pohybují v rozmezí od 4 do 8 milionů. Rozdíl vyplývá z toho, že stoupenci nižšího čísla za Francouze považují každého, kdo má alespoň jednoho rodiče, který se narodil ve Francii. Děti přistěhovalců podle nich už jsou „Francouzi stejní jako ostatní.“ Naproti tomu jejich oponenti ${ }^{\mathbf{2 8}}$ trvají na pojmu „Francouzi po mnoho pokolení,“ což znamená, že ve Francii musí být narozeni i jejich praprarodiče. $\mathrm{O}$ potomcích přistěhovalců hovoří jako o těch, kteři jsou Francouzi jenom podle osobních dokladů, ale jinak jsou „viditelně odlišní.“

$S$ počtem Francouzů narozených do rodin přistěhovalců souvisí další problém, a tím je porodnost. $V$ současné době na jednu Francouzku připadá 1,7 dítěte, ale ženy přistěhovalců rodí v průměru 2,8 dítěte. ${ }^{29}$ Ale během posledních deseti let natalita poklesla z hodnoty 2,03 na $1,88 .{ }^{30}$ Nejvyšší koncentrace přistěhovalců je na chudých předměstích velkých průmyslových metropolí. Nejznámějším z nich je departement Seine Saint-Denis na sever od Paříže, kde dřive byly dělnické byty, což bývala voličská bašta Francouzské komunistické strany. Dnes tam žije 600000 přistěhovalců, jejichž velká většina během posledních dvaceti let nechodila k volbám, protože neuznávala zastupitelskou demokracii jako takovou. ${ }^{31}$ Ale v posledních letech nastává změna, a ta bude vysvětlena na závěr této stati. Další velmi početné přistěhovalecké komunity žijí ve městě Blois a v jeho okolí (oblast řeky Loiry se spoustou krásných zámků na seznamu UNESCO), v jižní Francii (Provence-Alpes-Côte d'Azur) a stále více také v Alsasku, ${ }^{32}$ v Lyonu, v Grenoblu, v Bretani a v dalších vyspělých a bohatých oblastech. ${ }^{33}$

Přistěhovalecké oblasti se stále výrazněji odlišují od země, v níž se nacházejí. Jsou to jevy převážně kontroverzního charakteru, a to zejména v rovině náboženské, vzdělávací, kulturní, bezpečností a politické. Nosným společným jmenovatelem všech těchto rovin je sílící islamizace, která stále více rozšiřuje pomyslný příkop mezi oběma břehy. Hybnou silou procesu islamizace ve Francii jsou sami přistěhovalci, kteří se cílevědomě odlišují a oddělují od hodnot, uspořádání a životního způsobu společnosti, do které přišli nebo do níž se dokonce narodili. ${ }^{34}$

28 Michele Tribalat: Les Yeux grands fermés: L'Immigration en France. Paris, Denoël, 2010

29 Legros, Françoise: La fécondité des étrangères en France: une stabilisation entre 1990 et 1999, Insee, 2003-05, Numéro 898.

30 L'Express z 18. 7. 2018.

31 Gilles Kepel avec la collaboration de Leyla Arslan et Sarah Zouheir:Banlieue de la République (Institut Montaigne, oct. 11 ... www.laicite-republique.org > Think tanks", 30 sept. 2011 p. 29.

$32 V$ tomto historickém kraji se už dávno nediskutuje o tom, kdo má více předků z Francie nebo z Německa. Nastoupila nová dělící linie: kdo je evropského původu a kdo je přistěhovalec.

33 Jean-Marc Zaninetti: L'immigration en France : quelle géographie? Population \& Avenir 2010/2 $\left(n^{\circ} 697\right)$, pages 4 à 8.

34 Davet Gérard, Lhomme Fabrice : INCH'ALLAH - L'islamisation à visage découvert. Une enquête spotlight en Seine-Saint-Denis. Paris, Fayard, 2018. 


\subsection{Náboženská islamizace zdola}

Problematikou islamizace $v$ celoevropském měřítku se dlouhodobě zabývá americký specialista Christopher Caldwell. ${ }^{35}$ Ten ve své rozsáhlé monografii uzavírá, že chování pristěhovalců z muslimského světa má v evropských zemích dynamiku, která prochází celkem čtyřmi etapami. Nejprve se požaduje, aby se všichni muslimové rídili zásadami a přikázáními islámu. Ve druhé etapě už se zákony islámu musí rídit všichni příslušníci „muslimského společenství.“ V následující etapě se zákony islámu mají ř́dit i nemuslimové a v poslední, čtvrté etapě už se i nemuslimové mají chovat tak, aby nevzbuzovali podež̌ení, že se neř́dí zákony islámu. ${ }^{36}$ Tato jeho diagnóza byla svého času považována dokonce za skandální. ${ }^{37}$ Tento mechanismus velice zdařile popsal také francouzský spisovatel a novináŕ Michel Houellebecq ve své knize nazvané Soumission, ${ }^{38}$ která se stala celosvětovým bestsellerem, byla přeložena do mnoha jazyků, včetně českého.

$\checkmark$ náboženské rovině se islamizace projevuje trvalým nárůstem počtu mešit, je jich již přes 2000 a každý měsíc pribývají desítky dalších. $V$ důsledku toho se trvale rozrůstá počet a rozloha uzavřených a samovolně separovaných společenství, která se od země, do níž prišli, cílevědomě výrazně odlišují. Nemluví se v nich francouzsky, de facto tam neplatí tam zákony republiky, ale islám a šaría. Ústředním pilírem jejich vnitřního života je Halal, ${ }^{39}$ tedy věrnost manželovi, rodině, ale hlavně islámu. Př́sně se prosazuje tzv. endogamie, tedy uzavírání sňatků výlučně mezi členy těchto společenství. ${ }^{40}$ Velice symbolickým a záměrně zvýrazňovaným projevem islamizace se stal šátek, který nosí všechny muslimky. ${ }^{41}$

Rok 2003 se nesl ve znamení vyhrocených debat o nošení šátků. Tehdejší president Jacques Chirac nezastával názor, že by bylo nutné príijímat $v$ této věci zvláštní zákon, ale presto rozhodl o ustavení zvláštní komise, která to měla na starost. ${ }^{42}$ Ta nakonec text zákona připravila a předložila ho Národnímu shromáždění, a to jej nakonec dne 10. 2. 2004 schválilo pod názvem Zákon o náboženských symbolech ve veřejných školách. ${ }^{43}$ Dodnes

35 Absolvent Harvardovy univerzity, specialista na evropské politické záležitosti. Píše pravidelné úvodníky pro Financial Times, pro Weekly Standard a pro New York Times Magazine.

36 Christopher Caldwell, Une révolution sous nos yeux, préface de Michèle Tribalat, Traduction de l'anglais de Johan Frederik Hel Guedj, édition du Toucan, collection Adultes. Paris 2010, s. 343.

37 Alain Besançon: Un livre qui devrait faire scandale. Polémia, 23 Janvier 2010.

38 Houellebecq, Michel: Soumission. French, Flammarion, 2015. Autor velice poutavě popisuje, jak se $v$ akademickém prostředí, dokonce na pařižské Sorbonně, bude postupně prosazovat islamizace každodenního života.

39 François Gauthier : L'extension du domaine du halal. L'Homme 2019/2 (n² 230), pages 153 à 179

40 Gilles Kepel avec la collaboration de Leyla Arslan et Sarah Zouheir: Banlieue de la République (Institut Montaigne, oct. 11 ... www.laicite-republique.org > Think tanks", 30 sept. 2011 p. 14.

41 Farhad Khosrokhavar: "Une laïcité frileuse," Le Monde, November 20, 2003.

42 Françoise Lorcerie : La politisation du voile : l'affaire en France, en Europe et dans le monde arabe. L'Harmattan, 2005,

43 La loi sur les signes religieux dans les écoles publiques. 
se mu běžně ř́ká „zákon o nošení náboženských symbolů. “44 Tento zákon vyvolal ostré protesty vyznavačů islámu a dodnes je na mnoha místech okázale ignorován.

Na počátku tohoto století ve Francii nastala nevynucená, dobrovolná ghetoizace přistěhovalcủ $z$ islámského světa. $V$ těchto oblastech je i zcela jiná stravovací a stolovací kultura nežli ve většinové společnosti, ženy chodí zahalené, neuznávají se Vánoce, drží se půst $\mathrm{v}$ době ramadánu a silí tlak, aby se školní prázdniny přizpůsobovaly islámským svátkům i na celostátní úrovni a ve školních jídelnách už musí být i nabídka jídel vyhovujících vyznavačům islámu. Je tam mnohem nižší kvalita výuky na základních školách a také kázeň žákư. ${ }^{45}$ To je základní úroveň náboženské islamizace současné francouzské společnosti, v jejímž rámci je islám druhým nejrozšǐřenějším náboženstvím.

\subsection{Kulturní islamizace zdola}

Na náboženskou islamizaci navazuje islamizace ve školství a v kultuře. Významným kulturním a vzdělávacím nástrojem se stal systém nazývaný ELCO, tedy „výuka původního jazyka a kultury. ${ }^{46}$ Tu zajištují tzv. detašovaní imámové, což jsou znalci koránu, které do Francie vysílají muslimské země ze severní Afriky, ale také Turecko. Přitom mnozí $z$ nich vůbec nemluví francouzsky, komunikují pouze $v$ arabštině, poprípadě v turečtině. Situace je natolik vážná, že se $k$ ní v únoru tohoto roku veřejně vyjádřil i prezident Macron. Vysílání imámů v rámci systému ELCO označil výrazem „konzulární islám“ a vyhlásil odhodlání s tím skoncovat. ${ }^{47}$

Francouzské politiky stále více znepokojuje to, že imámové vysílaní z arabských zemí dětem a vnoučatům původních přistěhovalců, narozeným již ve Francii, tendenčním způsobem vykládají dějiny islámské civilizace a důkladně je seznamují $s$ islámem. Ten prezentují jako nejdokonalejší náboženství světa, které je nadřazené všem ostatním. Základní inspirací tohoto přístupu je džihádistická doktrína The Global Islamic Resistance Call (GIRC), která vyzvala k dalším teroristickým útokům proti Západu a zejména k přenesení války na území západní Evropy. ${ }^{48}$

Jako platforma pro násilný džihád mečem klade GIRC velký důraz na předstihující (preemptivní) teroristické útoky proti Západu kdekoliv na světě, a to jak na civilní, tak i na vojenské cíle. Cílem těchto útoků má být odradit Západ od vojenských intervencí

44 La Documentation française, La laïcité et l'école in "La laïcité: débats 100 ans après la loi de 1905», 2005.

45 Caroline Politi et Julie Saulnier: Ce qu'il faut retenir de Banlieue de la République. L'Express, 5. 10. 2011.

46 Oficiální název zní: Enseignement des Langues et Cultures d’Origines (ELCO). Je to systém výuky "původního jazyka» určený pro děti přistěhovalců. Tento systém byl zaveden na konci 90 . let minulého století.

47 Alexandre Lemarié: Contre le « séparatisme islamiste », Macron veut se positionner entre répression et intégration. Le Monde, le 19 février 2020.

48 M.W. Zackie Masoud: An Analysis of Abu Mus'ab al-Suri's "Call to Global Islamic Resistance" Journal of Strategic Security Volume 6 Number 1 Volume 6, No. 1: Spring 2013 Article 4 
v islámském světě. GIRC se obrací především na mladé muslimy žijící na okraji západoevropských společností a vyzývá je, aby bojovali jako samozvaní pachatelé teroristických útoků proti společnostem, ve kterých žijí. Jejím hlavním smyslem je co nejvíce podlamovat psychiku západní civilizace, nahlodávat její sebedůvěru a tím jí dávat najevo, že je jen otázkou času, kdy prohraje.

Západ je označován za bezbožný, zkažený, slabý, zbabělý, pokrytecký a dožívající bez pořádného smyslu pro vlastní život. $V$ tomto binárním hodnocení je Západ vykreslován jako těžká a vleklá choroba, zatímco islám je vydáván za léčbu. Západní vojenské operace v islámském světě, včetně francouzských, jsou odsuzovány jako třetí křižácká výprava, která je vedena s cílem dalšího drancování prírodního bohatství arabského světa. ${ }^{49}$

V oblasti školství a kultury se tedy cílevědomě prosazuje islamizace „zdola“, v jejímž důsledku narůstá podíl takových přistěhovalců, kteří své děti posílají jen do škol v rámci programu ELCO a zcela ignoruji školy francouzské. Řízená islamizace má vážné dopady na chování přistěhovalců od nejútlejšího věku. Na závažnost tohoto vývoje poukázal i sám prezident Macron a označil jej slovy „nepřijatelná deskolarizace," což je jev, který stále negativněji ovlivňuje celospolečenskou atmosféru. 50

Přistěhovalci a jejich synové nedodržují francouzská pravidla, odmítají podat ruku ženám, a to i ve školách, na úřadech, v nemocnicích, na policejních stanicích. Stále více sílí volání po zavádění dívčích škol a po stanovení časů, po které budou veřejné plovárny otevřeny jen pro ženy, které přeci mají právo být ušetřeny tzv. šarmérskému chování francouzských mužů, protože ho přeci považují za zcela neslučitelné s islámem. S tím úzce souvisí i jedno velice extremistické opatření - zabíjení těch islámských dívek, které se zamilují do Francouze a chtějí odejít od své původní rodiny. Je to typické hlavně pro Kurdy a občas se dokonce stává, že tohoto úkolu se z rozhodnutí rodin ujímají nezletilí bratři, kteří pak dostávají mnohem nižší tresty, než kdyby to vykonali otcové. ${ }^{51}$

Výše zmiňované skutečnosti ukazují, že ve Francii se nedaří ani integrace, natož pak asimilace přistěhovalců z islámského světa a dokonce ani jejich potomků, kteří už se narodili ve Francii. ${ }^{52}$ Lidé z přistěhovaleckého prostředí si stěžují, že Francouzi je nechtějí přijmout mezi sebe, rodilí Francouzi namítají, že se stále více cítí jako cizinci ve vlastní zemi. Stále více se zvýrazňuje vzájemné odcizení a nevraživost. Zvláště markantním projevem neúspěchu francouzského integračního modelu se stalo školství, kde se vůbec nepodařilo naplnit očekávání z poslední čtvrtiny 20. století. V oblastech s vysokou koncentrací přistěhovalců se namísto integrace reprodukují a umocňují nerovnosti, je v nich nejnižší úroveň vzdělanosti.

49 M.W. Zackie Masoud: "An Analysis of Abu Mus'ab al-Suri's 'Call to Global Islamic Resistance'". Journal of Strategic Security, Vol. 6, No.1 (2013).

50 Macron entame à Mulhouse une séquence dédiée à la lutte contre le communautarisme. LEXPRESS.fr avec AFP, publié le 18/02/2020.

51 Christopher Caldwell : Une révolution sous nos yeux, s. 322.

52 Camille Magnard : L'intégration des enfants d'immigrés à l'épreuve de l'école. France Inter, 15 septembre 2016 à $19 \mathrm{~h} 29$ 


\subsection{Sociální důsledky islamizace}

V oblastech s vysokou koncentrací přistěhovalců se projevuje řada vážných problémů také v sociální rovině. Především tam je dvojnásobná nezaměstnanost než v celostátním průměru. Lidé $z$ těchto ghett mají velké problémy už se sháněním jakékoliv práce, $v$ mnoha prípadech samotná adresa trvalého pobytu znamená konec nadějím. Pokud lidé $z$ těchto oblastí nějaké zaměstnání seženou, tak jsou to krátké a dočasné úvazky, přičemž vykonávají podřadnější a méně placené práce s únavným dojížděním na velké vzdálenosti.

Zvláště prekérní situace je u mladých, kteří už se narodili ve Francii. Ti vyrůstají a dospívají v prostředí, ve kterém již neplatí hodnoty a životní vzorce severoafrických společností, z nichž pocházejí jejich rodiče a prarodiče. A oni sami ještě nepatří do nové společnosti, nepřijali její hodnoty a způsoby a velmi těžko se do ní začleňují. Ve velkých přistěhovaleckých sídlištích nejsou nijak sociálně ukotveni, a navíc tam čelí velké kumulaci handicapů, v jejichž rámci se rychle stávají obětí gangů pouličního násilí a snadným cílem pro extremistické a teroristické organizace. Pro ně se islám stal ideologickou kompenzací a zároveň s tím je také velice účinným nástrojem pro jejich další radikalizaci.

Došlo dokonce k roztržce mezi dvěma předními francouzskými specialisty na islám. Gilles Kepel věnuje velkou pozornost teroristickým útokům ${ }^{53}$ a říká, že ve Francii dochází k radikalizaci politického islámu, ${ }^{54}$ jejímž základem je radikalizace desperátů. ${ }^{55}$ Naproti tomu Olivier Roy ${ }^{56}$ namítá, že probíhá islamizace politického radikalismu. ${ }^{57}$ Jejich nesho$d y^{58}$ jsou velice vyostřené a odrážejí, že v přístupu $k$ přistěhovalectví je rozpolcena celá Francie. ${ }^{59}$

\subsection{Bezpečnostní důsledky islamizace}

Dalším projevem neúspěchu integrace přistěhovalců ve Francii se stala bezpečnost. Výbušnost přistěhovaleckých oblastí se poprvé výrazně projevila již na podzim 2005, kdy na severních předměstích Paříže hořely automobily, byly rabovány obchody a přišly první

53 Kepel, Gilles, Jardin, Antoine: Terror in France: the rise of Jihad in the West. Princeton; Oxford: Princeton University Press, 2017.

54 Gilles Kepel, Antoine Jardin: Terreur dans l'Hexagone, Genèse du djihad français- Paris: Gallimard, 2015. Khosrokhavar, F:. Le nouveau jihad en Occident. Paris, Robert Laffont. 2018.

56 Wihtol de Wenden, Catherine: Géopolitique des migrations: 40 fiches illustrées pour comprendre le monde. Paris: Eyrolles, 2019, s. 69. Olivier Roy: Le Djihad et la Mort. Paris: Le Seuil, 2016.

58 Frédéric Boily: Le débat entre Gilles Kepel et Olivier Roy. Anatomie d’un désaccord.

59 "Gilles Kepel vs Olivier Roy, la guerre secrète des experts en terrorisme". Vanity Fair, January 28, 2019, https://www.vanityfair.fr/pouvoir/medias/story/ article-mag-gilles-kepel-vs-olivier-roy-la-guerre-secrete-des-experts-en-terrorisme/5209. 
brutální útoky na policisty. A od té doby se situace neustále zhoršuje, protože v místech s vysokou koncentrací pristěhovalců vládnou pouliční gangy organizovaného zločinu, jež řídí náctiletí násilníci, kteří se už narodili ve Francii. V roce 2015 zločinci z těchto vrstev připravovali i útoky na Stade de France během prátelského fotbalového zápasu Francie - Německo ${ }^{60}$, což navázalo na tragickou tradici podlých útoků během olympijských her v Mnichově $1972^{61}$ a maratónu v Bostonu 2013.62 Zároveň se vytvořila atmosféra strachu před olympijskými hrami, které bude $v$ roce 2024 pořádat Paříz.

Další rodáci z těchto předměstí se stali fanatickými džihádisty a odjeli bojovat do Iráku a do Sýrie. ${ }^{63}$ Podle policejních odhadů jich bylo několik stovek. Po návratu ze syrských bojišt' se stávají vážnou hrozbou pro bezpečnost Francie. ${ }^{64}$ Všechny tyto patologické jevy na jedné straně posilují komunitární soudržnost přistěhovaleckých předměstí, ale na druhé straně dále zvýrazňují rozdělení země.

$\checkmark$ neposlední řadě je $v$ přistěhovaleckých sídlištích nejnižší úroveň každodenní bezpečnosti, policisté do mnoha těchto míst nejprve odmítali jezdit v noci a dnes už tam nechtějí jezdit ani ve dne. Byli tam totiž mnohokrát zákeřně napadeni, několik jich bylo i smrtelně zraněno. ${ }^{65}$ Jejich odboroví předáci hovoří doslova o občanské válce, která probíhá v přistěhovaleckých předměstích v režii a podle pravidel džihádistických předáků. ${ }^{66}$

\subsection{Nástup politické islamizace zdola}

Řízená islamizace se stále silněji projevuje i na poli vnitřní politiky. Ve Francii působící imámové frontálně odsuzují francouzské politiky pro jejich zkorumpovanost, prolhanost, omílání povýšeneckých frází, krytí velkých podvodů a rozkrádání státního majetku. Na poli zahraniční politiky Francii vyčítají podporu zkorumpovaných režimů v arabském světě, drancování jeho surovinového bohatství, vojenské intervence a následné okupace. Francouzskou politiku označují za prohnilou, islamizaci vydávají za její léčbu.

Velká pozornost se $v$ rámci politické islamizace soustřed'uje na volby do obecních zastupitelstev. Čelní představitelé muslimských sdružení připravují své kandidátní listiny do obecních voleb ve všech oblastech, kde je silné zastoupení přistěhovalců. Stále

60 Les attentats du 13 novembre 2015 à Paris et à Saint-Denis. L'Express, 14. 11. 2015.

61 Groussard, Serge (New York, 1975), The Blood of Israel: the massacre of the Israeli athletes, the Olympics, 1972.

62 Boston Marathon Bombing - Victims, Suspects \& Facts ...www. history.com > topics > boston...28. 3. 2014.

63 David Thomson, Les Français jihadistes, Paris, Les Arènes, 2014.

64 Farhad Khosrokhavar: Qui sont les jeunes Jihadistes français? Rhizome 2016/1 (N59), pages 69 à 73.

65 Policiers, gendarmes, militaires: les attaques se ...https://www.ouest-france.fr/faits-divers/ attentat/...

66 Yves Mamou: France: la Guerre contre les Pompiers et la Police, 12 janvier 2018, https:// fr.gatestoneinstitute.org/11735/france-guerre-pompiers-police. 
výrazněji se na jejich sestavování a na prípravě vybraných kandidátů podílejí výše vzpomínaní konzulární imámové. Cílem tohoto tažení je získat co největší vliv na řízení obcí a pak i kantonů. Je to politická islamizace zdola, která cílevědomě umocňuje náboženskou islamizaci zdola a je pojímána jako základ pozdějších bojů za získání politických funkcí na vyšší úrovni. Úspěchy na obecní úrovni se mají stát odrazovým můstkem pro pronikání do vyšších politických pater.

Politická islamizace ve Francii však má i významný mezinárodní aspekt. Sílí v době, kdy se tento fenomén rozvijí i v dalších zemích západní Evropy, zejména v sousedním Německu. Tam důležitou úlohu sehrává současný turecký prezident Erdogan, který zcela kategoricky odmítá asimilaci a podporuje islamizaci přistěhovaleckých komunit. Jeho militantní vyjádření nakonec vedla k vážné eskalaci mezi oběma zeměmi. ${ }^{67}$

\section{DEBATY O PŘıstĚHOVALECTVÍ}

Od počátků tohoto století se ve Francii vedou rozsáhlé a velice vyhrocené debaty o podstatě a príčinách problémů s přistěhovalci a o možnostech jejich řešení. Diskutuje se především o následujících hlavních otázkách: kdo je a kdo není Francouz? Kdo je a kdo není přistěhovalec? Kolik je ve Francii přistěhovalců, prijímá jich Francie hodně nebo málo? Jsou přistěhovalci hrozbou? Jaké jsou náboženské souvislosti a důsledky přistěhovalectví, jakou politiku by měla Francie uplatňovat?

Dosavadní debata o přistěhovalectví měla dvě etapy. První probíhala v prvním desetiletí tohoto století, druhá vrcholí v právě končícím desetiletí. $V$ debatách se vyprofilovaly dva protikladné názorové proudy. První proud vyznává politickou korektnost, druhý ji otevřeně odmítá.

\subsection{První debata v letech 2000 - 2010}

Během této etapy Francii vládli dva prezidenti - Jacques Chirac a Nicolas Sarkozy. První z nich na začátku svého druhého mandátu prosadil zákon o zákazu náboženských ve státních školách, což mírilo především na šátky, kterými si své obličeje zakrývaly žákyně a studentky islámského vyznání. Prezident to zdůvodnil slovy, že šátky, stejně jako ostatní okázalé náboženské symboly v sobě mají cosi útočného, cosi co směřuje proti laickému charakteru státu a školství. ${ }^{68}$ Následující reakce muslimů byly velice odmítavé a ukázaly, jak vysoký byl stupeň radikalizace muslimů ve Francii. ${ }^{69}$

67 France-Turquie : I'inquiétante escalade entre Macron et Erdogan. www.jeuneafrique.com , politiquewww.jeuneafrique.com > politique. 30.6. 2020 lefigaro.fr > Actualité > Société, 26. 7. 2018. 
A když se funkce ujímal jeho nástupce Sarkozy, vyznačovala se situace dvěma hlavními rysy: proud přistěhovalcủ neslábl a navíc se snižovala jejich kvalita. ${ }^{70}$ Sarkozy proto, ještě před nástupem do funkce prezidenta, dospěl k závěru, že Francie by si měla vybírat, koho přijme a koho naopak odmítne. ${ }^{71}$ Výrazně zaujal v roce 2005 , když byla vážně ohrožena bezpečnost na předměstích - byla zapalována auta a děly se další nepřístojnosti (dnes už se všeobecně uznává, že to byla reakce na OIF 2003) a Sarkozy dokonce vyhlásil, že ti,

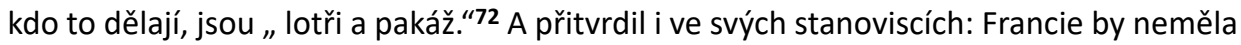
trpět, že tam prijide každý, komu se zachce (une immigration choisie et non subie).

\subsubsection{Hlavní argumenty politické korektnosti}

Hlavní autoritou tohoto názorového proudu se stal přední francouzský demograf Hervé le $\operatorname{Bras}^{73}$. Zastává názor, že Francouzem je každý, kdo může prokázat, že alespoň jeden $z$ jeho rodičů se narodil ve Francii, a tak dochází $k$ závěru, že počet přistěhovalců ve Francii nepřesahuje 4 milióny. On sám $v$ rámci politické korektnosti nepoužívá pojem přistěhovalci, ale volí výraz „lidé vzešlí z diverzity“. Odmítá názor, že by jich Francie přijímala hodně. ${ }^{74}$ Proces príchodu pristěhovalců označuje pojmem „infuze“ a tvrdí, že počty príchozích jsou přiměřené možnostem Francie. ${ }^{75}$ Klady spatřuje $v$ tom, že se zlepšuje vzdělanost a kvalita lidí, kteří přicházejí z MENAP. ${ }^{76}$

LE BRAS, Hervé, Le démon des origines. Démographie et extrême droite, La Tour-d'Aigues : Éd. de l'Aube, 1998, 260 p.Ve veřejných debatách argumentuje, že jiné země (např. SRN a Švédsko) přijímají na počet svých obyvatel ještě více přistěhovalců nežli Francie. Odmítá názor, že přistěhovalci by znamenali hrozbu pro bezpečnost Francie a zcela kategoricky se vymezuje proti př́stupu zvanému „amalgam." Pod tímto pojmem se myslí velice rozšířená asociace mezi přistěhovalci, organizovaným zločinem a terorismem. Hervé le Bras tvrdí, že zdaleka ne všichni přistěhovalci se zapojují do činnosti organizovaného zločinu a že teroristické útoky nepáchají přistěhovalci, ale již lidé, kteří ve Francii vyrostli. ${ }^{77}$ Pokud jde o př́stup státu $\mathrm{k}$ přistěhovalcům, Hervé le Bras se přimlouvá za určitou kontrolu migrace, jejímž cílem by bylo, aby Francie prijímala jen takové cizince, které

70 Fallaci, Oriana: La rage et l'orgueil, Paris: Plon, 2002.

71 Au Mali, Sarkozy prône un «partenariat rénové» et justifie sa loi sur l'immigration. Le Figaro, le 18 mai 2006.

72 Nicolas Sarkozy continue de vilipender "racailles et voyous" www.lemonde.fr > Société 11 nov. 2005.

73 Le Bras, Hervé: Le démon des origines. Démographie et extrême droite, La Tour-d'Aigues. Éd. de I'Aube, 1998.LE BRAS, Hervé, Le démon des origines. Démographie et extrême droite, La Tour-d'Aigues: Éd. de l'Aube, 1998LE BRAS, Hervé, Le démon des origines. Démographie et extrême droite, La Tourd'Aigues : Éd. de l'Aube, 1998, 260 p.

74 Les statistiques ethniques, un sujet tabou. Libération, 19 novembre 2005.

75

76 Le Bras, Hervé: "Se plaindre de la diversité, c'est méconnaître l'histoire de France ». www.cairn.info , revue-migrations-societe-2010-5-page-...

77 Hervé Le Bras: "La ruée migratoire vers l'Europe, c'est un grand fantasme", www.lecho.be > Opinions , Carte Blanche, 27. 4. 2019. 
sama chce a potřebuje. A před nebezpečím tohoto zjednodušujícího přirovnání varuji i další autoři. ${ }^{78}$

\subsubsection{Hlavní argumenty kritického prístupu}

Pozici na opačném pólu francouzských debat o přistěhovalectví zaujala demografka Michele Tribalat. ${ }^{79}$ Ta si stojí za svým pojmem Francouzi po mnoho pokolení, kterými jsou pouze ti, kteři maji i prarodiče a praprarodiče narozené ve Francii. Pro jiné obyvatele své země používá výraz přistěhovalci z Magrebu a subsaharské Afriky a tvrdí, že ve Francii jich je 8 milionů, což je 12 \% veškerého obyvatelstva země. Na základě toho shrnuje, že přistěhovalců do Francie přichází hodně a že to je doslova invaze, přičemž jejich ekonomický př́inos je podstatně menší, než se v zemi tvrdí.

Již na samém počátku tohoto století psala, že přistěhovalci jsou bezpečnostní hrozbou, a to hlavně kvưli tomu, že jejich druhá a nyní už i třetí generace je v př́stupu k Francii a k jejím hodnotám negativistická, kontroverzní a neprátelská. ${ }^{80} \mathrm{~A}$ ve své nejznámější knize nazvané „Oči dokořán zavřené“ varuje, že přistěhovalci soustavně stupňují svoje politické a náboženské požadavky, ${ }^{81}$ a tím etnické Francouze dostávají pod stále silnější tlak. ${ }^{82}$

V pojetí Michele Tribalat je islám náboženstvím vzpoury, radikalismu a násilných protestů včetně terorismu. Varuje před tím, že čím nižší je věk přistěhovalců, tím silnější je $v$ jejich řadách vliv radikálního islámu, zatímco mladí Francouzi mají ke křestanství stále vlažnější př́stup, a tak se situace vychyluje stále více ve prospěch radikálního islámu a $v$ neprospěch křest́anství. Zvlášt velké nebezpečí spatřuje $v$ tom, že potomci přistěhovalců francouzskou společnost zastrašují a páchají proti ní teroristické útoky. ${ }^{83}$ Jejich chování dává do protikladu s Free Muslim Coalition Against Terrorism (FMCAT) ${ }^{84}$ v USA, která je mnohem sebekritičtější do vlastních řad.

Za vážnou hrozbu pro blízkou budoucnost považuje pronikání džihádistů do policie a výhledově i do armády. Připomíná, že $v$ době povinné vojenské služby bylo mezi vojáky přistěhovaleckého původu a muslimského vyznání mnohem více neposlušnosti a kázeňských prohřešku nežli mezi vojáky francouzského původu. ${ }^{85}$ Volá po striktním omezení přijímání přistěhovalců a zcela odmítá politikou korektnost. Od svých oponentů si

78 Emmanuelle Santelli: Immigrés et descendants d'immigrés entre ressemblances et spécificités : les dangers des amalgames. Migrations Société 2007/3-4 (N¹11-112), pages 189 à 200.

79 Pierre Cassen: Michèle Tribalat, démographe, auteur de "La République et l'islam. ripostelaique.com Michele-Tribalat-demographe-auteur.

80 Michèle Tribalat, Jeanne-Hélène Kaltenbach: La République et I'Islam: Entre crainte et aveuglement. Paris: Gallimard, 2002.

81 Michèle Tribalat: Les Yeux grands fermés : L'Immigration en France. Paris, Denoël, mars 2010.

Michèle Tribalat: "L'islam reste une menace", Le Monde, www.lemonde.fr > Idées, 13 oct. 2011.

Michèle Tribalat: "Les pouvoirs publics relativisent l'immigration". L'Express, 18. 2. 2010.

84 Tato nevládní organizace byla založena s cílem potlačovat islamistický extremismus a terorismus a posilovat sekulární demokratické instituce na Blízkém východě a v celém muslimském světě. Velice tvrdě kritizuje teroristické útoky a jejich pachatele. Ve Francii něco takové vůbec neexistuje.

Osobní rozhovor, 17. 11. 2019. 
vysloužila obvinění, že pracuje ve prospěch krajně pravicové Národní fronty, což samo o sobě svědči o politické vyhrocenosti debaty o přistěhovalectví. ${ }^{86}$ Ona odpovídá slovy, že politická korektnost je ve své podstatě alchymií a svým kritikům vytýká, že vědomě zavírají oči před tím, co je již dávno evidentní.

\subsection{Druhá debata v letech 2010 - 2020}

Na nejvyšší politické úrovni byla debata o přistěhovalectví ovlivněna výrokem tehdejšího prezident Francois Hollanda, který veřejně vyhlásil optimistický názor, že demokracie a islám jsou kompatibilní. ${ }^{87}$ Jenomže následující roky přinesly sérii krutých teroristických útoků, které Hollandovým optimismem hodně otřásly.

\subsubsection{Teroristické útoky jako silný katalyzátor}

Francie se nezúčastnila operace Irácká svoboda, a tak byla na rozdíl od Španělska a Velké Británie ušetřena velkých teroristických útoků, které páchali synové přistěhovalců, tzv. home grown terrorists. ${ }^{88}$ Docházelo $\mathrm{k}$ relativně malým útokům, které cílily predevším na Francouze židovského původu a vyznání. Konkrétně to byly cílené útoky na židovské vojáky a policisty, na židovské košer obchody. ${ }^{89}$ Nejohavnější podobu měly útoky na židovské školy a školky. ${ }^{90}$

Zásadní zlom nastal až poté, co Francie začala vojensky intervenovat v islámských zemích, v Mali, ve Středoafrické republice a zejména v Sýrii. Jako pomsta pak přišly útoky, kterým se ř́ká "conlict generated terror, ${ }^{91}$ tedy terorismus vyvolaný vojenským konfliktem. Velmi kontroverzním faktorem jsou vojenské intervence Západu v zemích islámského světa a následující vojenské okupace. Ty jsou velice často zmiňovány jako hlavní pohnutka nenávisti, radikalizace a touhy po pomstě. Začal s tím už Usáma bin Ládin a dodnes v tom pokračují jeho následovníci. Ti všichni svorně vyhlašují, že nejvíce trpícími zeměmi dnešního světa jsou Palestina, Irák a Afghánistán.92

A konkrétně ve Francii se to projevilo tak, že roku 2015 nastoupila vina velice brutálních útoků, jejichž smyslem byla msta za vojenské intervence a při kterých byly cíleně

86 Immigration : qui est Michèle Tribalat, la démographe adulée par le FN? www.nouvelobs.com > ... , Politique 28. 10. 2013.

87 François Hollande: „L'islam et la démocratie sont compatibles ...fr.le360.ma > politique > francois-h...14. 7. 2013

88 Yener Altunbas, John Thornton: Are Homegrown Islamic Terrorists Different? Some UK Evidence. Southern Economic Journal, Vol. 78, No. 2 (October 2011), s. 262-272.

89 Attaque du supermarché Hyper Cacher: un otage raconte ...https://www.liberation.fr/ societe/2015/01/11/hyper...

90 "Rapport Obin": Les signes et manifestations d'appartenance religieuse dans les établissements scolaires (juin 04). Comité Laïcité République, s. 22.

91 Stepanova, Ekaterina (2003): Anti-terrorism and Peace-building During and After Conflict. Stockholm: SIPRI, 2003.

92

Christopher Caldwell: Une révolution sous nos yeux, s. 229. 
zabíjeny desítky lidí. Především to byl útok v Bataclanu dne 13. 11. 2015.93 pak následoval útoky v Nice, ${ }^{94}$ který byl záměrně spáchán v den státního svátku, 14. 7. 2016, kdy jeden přistěhovalecký desperát najel kamionem do davů lidí. Tento útok měl doslova devastující politické dopady, ztrátou svého kreditu za ně zaplatili tehdejší socialistická vlády a především jejího premiér Manuel Valls. Další šokující úder přišel dne 26. 7. 2016, kdy byl, v den svátku svaté Anny, babičky Ježíše Krista, v malém bretaňském městě Saint-Étienne-du-Rouvray popraven šestaosmdesátiletý katolický kněz. ${ }^{95}$ Také tento útok spáchali synové přistěhovalců, vykřikovali při něm, že se mstí za Sýrii. A další krutý útok se odehrál ve Štrasburku, kde další syn přistěhovalců zastřelil pět lidí na vánočním trhu.96

\subsubsection{Hlavní argumenty politické korektnosti}

Výše zmiňované teroristické vedly $\mathrm{k}$ dalšímu vyhrocení střetů mezi tzv. korektními a kritickými autory. Hlavním představitelem politické korektnosti je Francois Héran, ${ }^{97}$ který v mnohém navazuje na stanoviska, která předtím vyjádřil Hervé le Bras. Týká se to hlavně kritérii pro posouzení toho, kdo je a kdo není Francouz, kolik je v zemi přistěhovalců, zda jich je hodně nebo málo. Zdůrazňuje, že přistěhovalectví je celosvětová realita a že je nesmysIné proti ní bojovat. Zdưrazňuje, že to není hrozba a že přistěhovalci jsou přínosem pro vzájemné mísení a obohacování („,brassage“, pojem odvození od vaření piva). A především odmítá tzv. amalgam, tedy rovnítko mezi teroristickými útoky a přistěhovalci.

\subsubsection{Hlavní argumenty kritického prístupu}

Místo v jeho čele zaujal Stephen Smith a ten je ještě kritičtější, než byla Michele Tribalat. Jeho monografie nazvaná Nával do Evropy ${ }^{98}$ vyvolala velkou pozornost a spoustu protichůdných reakcí. Obdržela několik velkých cen, včetně Velké ceny Francouzské akademie. Stephen Smith píše, že ve Francii je celkem 8 milionů přistěhovalců, což představuje 12 \% všeho obyvatelstva. Tvrdí, že jich je mnoho, a to nejen ve Francii, ale v celé Evropě. Jeho ústřední argument zní, že nastává „velké přemístění z Afriky do Evropy a že do roku 2050 bude na Afričany připadat $25 \%$ obyvatelstva EU, tedy až 200 milionů.

Píše o prílivu „,hord přistěhovalců a nových barbarů," kteří podle něho budou vytvářet diaspory jakožto předmostí pro další pronikání, $v$ důsledku čehož budou přistěhovalci rodilým Francouzům stále více vadit. Varuje, že se vytvoří Euroafrika, což bude konec evropského sociálního modelu a evropské bezpečnosti. Islám považuje za vážnou bezpečnostní hrozbu, která s sebou přinese radikálnost, nesnášenlivost a nenávist a v důsledku

93 "Paris Attacks: Hollande Blames Islamic State for 'Act of War'," BBC News, November 14, 2015, https:// www.bbc.com/news/world-europe-34820016.

94 Vincent Vantighem, Olivier Aballain: "Attentat de Nice: Comment un camion de location est devenu une arme meurtrière". 20 Minutes, July 15, 2016,

95 "Prêtre tué à Saint-Étienne-du-Rouvray: ce que l'on sait," Le Monde,|July 27, 2016,

96 "Fusillade à Strasbourg: deux morts et plusieurs blessés, la piste terroriste évoquée," L'Orient-Le Jour, December 11, 2018, https://www.lorientlejour.com/article/1147886/fusillade-a-strasbourg-deuxmort-et-onze-blesses-la-piste-terroriste-evoquee.html.

97 François Héran: Avec l'immigration. Mesurer, débattre, agir. La Découverte, 2017.

98 Stephen Smith: La Ruée vers l'Europe. La Jeune Afrique en route pour le Vieux Continent. Paris : Éditions Grasset, 2018. 
toho se podle něho z Evropanů se stanou troglodyti, kteří se zcela uzavřou do sebe. Proto volá po striktním omezení přistěhovalectví.

Jeho stoupenci píší o pilírové knize, kterou si musí přečíst každý, kdo se touto problematikou chce zabývat. ${ }^{99}$ Odpůrci mu vytýkají, že vyznává komplotistickou doktrínu, že je otevřeně xenofobní a že šírí strach. ${ }^{100}$ Mají mu za zlé, že je jednoznačným stoupencem tzv. amalgamu, který považuje nárůst terorismu za výsledek narůstajícího počtu přistěhovalců a že okázale odmítá politickou korektnost. At' tak či onak, tuto knihu s uznáním citoval i sám prezident Macron. ${ }^{101}$

Tabulka č. 1: Hlavní témata názorových rozepří

\begin{tabular}{|c|c|c|}
\hline & Politicky korektní autoři & Kritičtí autoři \\
\hline $\begin{array}{l}\text { Kdo je a kdo není } \\
\text { Francouz }\end{array}$ & $\begin{array}{l}\text { On/ ona a alespoň jeden ro- } \\
\text { dič se narodili ve Francii }\end{array}$ & Francouzi po mnoho pokolení \\
\hline $\begin{array}{l}\text { Kdo je a kdo není } \\
\text { přistěhovalec }\end{array}$ & Lidé vzešlí z diverzity & Přistěhovalci \\
\hline $\begin{array}{l}\text { Kolik je ve Francii } \\
\text { přistěhovalců }\end{array}$ & $\begin{array}{l}4 \text { mln (6\%) } \\
\text { Přicházejí hl. z Magrebu a } \\
\text { subsaharské Afriky }\end{array}$ & $\begin{array}{l}8 \mathrm{~m} \ln (12 \%) \\
\text { Přicházejí hl. z Magrebu a subsaharské Afriky }\end{array}$ \\
\hline $\begin{array}{l}\text { Přijímá jich Francie } \\
\text { hodně nebo málo? }\end{array}$ & $\begin{array}{l}\text { Přiměřeně, je to infúze, zlepšu- } \\
\text { je se jejich vzdělanost a kvalita } \\
\text { Jiné země jich přijímají více } \\
\text { (např. SRN a Švédsko) }\end{array}$ & $\begin{array}{l}\text { Hodně, je to invaze, která Fran- } \\
\text { cii stále více oslabuje }\end{array}$ \\
\hline $\begin{array}{l}\text { Bezpečnostní stránka } \\
\text { věci: Jsou přistěho- } \\
\text { valci hrozbou? }\end{array}$ & $\mathrm{Ne}$, nejsou & $\begin{array}{l}\text { Ano, jsou, a to hl. islamismus a jeho po- } \\
\text { liticko - náboženské požadavky, } \\
\text { Je to typické hlavně pro } 2 \text {. generaci přistěhovalců, } \\
\text { která je negativistická, kontroverzní, nepřátelská, } \\
\text { Zastrašování a teroristické útoky, } \\
\text { pronikání džihádistů do poli- } \\
\text { cie a výhledově i do armády }\end{array}$ \\
\hline $\begin{array}{l}\text { Amalgam }{ }^{102} \text { jakožto } \\
\text { etická stránka věci: }\end{array}$ & Jednoznačně jej odmítá & Nezř́iká se ho \\
\hline $\begin{array}{l}\text { Náboženská } \\
\text { stránka věci }\end{array}$ & & $\begin{array}{l}\text { Islám je náboženstvím vzpoury a radikalismu, } \\
\text { Čím nižší je věk, tím silnější je } \\
\text { vliv radikálního islámu } \\
\text { Naproti tomu mladí Francouzi mají ke křes- } \\
\text { tanství stále vlažnější přístup, a tak se situace } \\
\text { vychyluje stále více ve prospěch islámu }\end{array}$ \\
\hline
\end{tabular}

99 Eugénie Bastié : « Tribalat, Guilluy, Smith, victimes de l'universitairement correct ? », Le Figaro, 22.-23. décembre 2018, s. 13.

100 François Héran: «Comment se fabrique un oracle ", La Vie des Idées,|' 18 septembre 2018 (lire en ligne [archive], consulté le 23 janvier 2019.

101 Immigration: les thèses à rebours de Stephen Smith, l'africaniste cité par Macron » [archive]. Figaro, 16 avril 2018.

102 Jedná se o velice rozšířenou asociaci mezi přistěhovalci, organizovaným zločinem a terorismem. 


\section{PŘ̆ISTĚHOVALECTVÍ A ARMÁDA}

Z hlediska ozbrojených sil se potomci přistěhovalců dělí do dvou základních skupin. Tu první tvoří ti, kteři se uzavírají do sebe a do svých vyloučených čtvrtí a vůči Francii zaujímají nepřátelské stanovisko. Ale ve druhé skupině jsou ti, kteří chtějí něco dokázat a chtějí se integrovat. Ti projevují nárůst důvěry v demokracii, v republikánské uspořádání a hodnoty. Váží si rovných př́ležitostí, které jim republika nabízí a stále méně se váží na zemi, ze které přišli jejich rodiče nebo prarodiče. ${ }^{103}$ | když jejich rodiče ještě udržují kontakty s príbuznými v rodné zemi, oni sami jsou již více orientováni na Francii, a tak pro ni nepředstavují žádnou zásadní bezpečnostní hrozbu. ${ }^{104}$

A pokud jde konkrétně o armádu, vstupují do ní ti potomci přistěhovalců, kteří k ní mají pozitivní vztah, a to hned z několika důvodů. Především jim dává možnost vymanit se z determinismů, které je silně limitují v jejich rodném prostředí. Dalším důvodem je, že v genech mají úctu $\mathrm{k}$ otcům a dědům a respekt $\mathrm{k}$ jejich rozhodnutím. Proto uznávají vojenskou hierarchii, autoritu nadřizených a také profesionalizaci, která jim dává možnosti dalšího osobnostního rozvoje, včetně dobrého př́ijmu a dovolených. A za třetí je to možnost kariérního postupu, hrdost na uniformu, dosaženou hodnost a funkci. ${ }^{105}$ Služba $v$ armádě se pro ně stává obdobím, během kterého se více sžívají s republikánskými a demokratickými hodnotami a zvyklostmi.

Tabulka č. 2: Islám v ozbrojených silách

\begin{tabular}{|l|l|}
\hline $\begin{array}{l}\text { Vojenská služba pohle- } \\
\text { dem přistěhovalců }\end{array}$ & $\begin{array}{l}\text { Možnost vymanit se z limitů daných komunitním prostředím } \\
\text { Možnosti osobnostního rozvoje } \\
\text { Možnosti kariérního postupu, hrdost na uniformu, dosaženou hodnost a funkci }\end{array}$ \\
\hline $\begin{array}{l}\text { Př́nos přistěhovalců } \\
\text { pro ozbrojené síly }\end{array}$ & Mise v zámoří, zejména v islámském světě, kde se Francie stává jejich referenční zemí \\
\hline Konfliktní aspekty & $\begin{array}{l}\text { Výhrady vojáků francouzského původu vůči vymoženostem vojá- } \\
\text { ků islámského vyznání (ramadán, strava, časté modlitby) }\end{array}$ \\
\hline
\end{tabular}

Vojáci vzešlí z islámského prostředí jsou použitelní zejména při misích $v$ islámském světě, kde mohou dobře působit na tamní obyvatelstvo. Právě mise $v$ zahraničí vedou k tomu, že pro tyto vojáky se Francie stává zemí, na kterou se odvolávají a která jim dává príležitost, aby se angažovali za všeobecné hodnoty a za jejich prosazování v zahraničí nebo dokonce $v$ jiném civilizačním okruhu. Ale na druhou jsou mise i určitým úskalím. $\checkmark$ nich se prolínají náboženské motivy i obyčejná nesnášenlivost, která může narušovat kohezi vojenských jednotek.

103 Sylvain Brouard, Vincent Tiberj: Français comme les autres? Enquête sur les citoyens d'origine maghrébine, africaine et turque. Paris: Presses de Sciences Po, 2005.

104 Evelyne Ribert: Liberté, égalité, carte d'identité: les jeunes issus de l'immigration et l'appartenance nationale. Paris: La Découverte, 2006.

105 Christophe Bertossi, Catherine Wihtol de Wenden: Les couleurs du drapeau: l'armée française face aux discriminations. Robert Laffont, 2007. 
Vojáci francouzského původu těžce nesou, že jejich kolegové nejedí vepřové maso a místo něho dostávají bifteky, že si vyhrazují místnosti a doby pro modlitby. Nejvíc jim vadí doba ramadánu, během nich věříci muslimové vyžadují delší čas na modlení a sníženou fyzickou zátěž. V důsledku pak dochází k šikanování. To má nejčastěji slovní podobu, která je však dost urážlivá. Projevuje se to zejména po teroristických útocích a po výbuchu násilností na předměstích velkých francouzských měst. Tyto skutečnosti někdy i narušují kohezi základních jednotek. Celkově však v přijímání potomků přistěhovalců do ozbrojených sil převládají kladné stránky.

\section{ZÁVĚR}

Francouzská zkušenost ukazuje, že přistěhovalecké čtvrti se z hlediska zeměpisného nacházejí na okrajích velkých měst, ale z hlediska politického se stále více dostávají do centra vyhrocených debat. $V$ jejich průběhu se vyhrotilo předpojaté dělení na politicky korektní vs. nekorektní přístupy. Problémem politicky korektního proudu je to, že si z něj berou silnou inspiraci nejvyšší představitelé muslimských obcí v zemích EU: po každém útoku opakují, že takové násilí je v rozporu s islámem a že ti, kdo útočili, vlastně nejsou muslimové. Nikdy se neomlouvají, vždy jen obecně odsuzují spáchané násilí, což dále rozvíjí a stupňuje islamizaci zdola. Úskalím kritického, politicky nekorektního proudu je to, že se na něj odvolávají krajně pravicové, xenofobní a protipřistěhovalecké strany, které posilují nejen ve Francii, ale ve všech zemích s velkými přistěhovaleckými oblastmi, jimž se přezdívá No Go Zones. A tato skutečnost vede $k$ další vnitropolitické bipolarizaci mezi tzv. politicky korektními a nekorektními autory, což je vlastně nová podoba tolik kritizovaného amalgamu, která $v$ evropských společnostech brání tolik potřebným věcným debatám.

Na vyhrocenost problematiky vztahu mezi přistěhovalectvím a zhoršováním vnitrostátní bezpečnosti velice důrazně poukázala i senátorka Jacqueline Eustache-Brinio ${ }^{106}$ ve své zprávě ze dne 7. 7. 2020.107 Ta za ústřední problém označila „politický islám,,"108 tedy frontální pronikání radikálního islámu do všech oblastí francouzského života, včetně politiky. Dále uvedla, že hlavními hybateli tohoto asertivního postupu jsou Muslimské bratrstvo a Celostátní výbor muslimského náboženství (CCIF), který má velmi silný vliv na všechny muslimy v zemi. Varovala i před hlavní vývojovou tendencí: muslimští vưdcové před 15 lety chtěli, aby se ve Francii stavěly mešity, ale dnes už tlačí na to, aby se stavěly

106 Původním povoláním středoškolská profesorka, která se už 40 let plně angažuje v politice, v klasické neoliberální a gaullistické pravicové straně UMP, která se před pěti lety přejmenovala na Republikány. V letech 2001 à 2017 byla starostkou města Saint-Gratien v pařížské oblasti a byla jeho. Funkci opustila až potom, když byla před třemi lety zvolena do Senátu a šla př́kladem v tom, že nechtěla hromadit placené funkce ve státní správě.

107 Jacqueline Eustache-Brinio : radicalisation islamiste " Être dans le déni serait irresponsable. "www. lesrepublicains-senat.fr > spip. 10. 7. 2020

108 Jacqueline Eustache-Brinio : "La France est confrontée à une pression de I'Islam Politique.» www.atlantico.fr > decryptage > jac...10. 7. 2020 
i muslimské školy. Řešení spatřuje ve zpřísnění především na poli soudnictví a policejních prístupů.

Celoevropský význam mají stanoviska současného prezidenta a nedávného premiéra. ${ }^{109} \mathrm{Ti}$ zdůrazňují, že je nutné skoncovat $\mathrm{s}$ islamistickým separatismem ve Francii ${ }^{110} \mathrm{a}$ zároveň s tím obnovit kontrolu nad migrační politikou, kladou důraz na rovnováhu mezi právy a povinnostmi, na návrat ke státní suverenitě a ke kvótám, na zpřísnění přistupu ke zdravotní péči, na navýšení počtů personálu Frontexu z 1000 na 10.000, a to do roku 2027 a na selekci, aby si země vybíraly jen takové přistěhovalce, jejichž profese Francie potřebuje. ${ }^{111}$

U prezidenta Macrona dokonce sílí kritický přístup $\mathrm{k}$ islámskému radikalismu. Ve významném projevu dne 4. 9. $2020^{112}$ velmi důrazně odsoudil snahy „separovat se ve jménu náboženství od republiky, neřídit se jejími zákony a mařit vzájemné soužiti. “113 Proto prezident klade důraz na zrušení vzdělávání dětí přistěhovalců doma, na kontrolu náboženských škol a na konec imámů, kteří do Francie príjiždějí ze zahraničí. ${ }^{114}$

A ještě př́ikřejší stanoviska prezident Macron vyjádřil dne 16. 10. 2020, potom, co jeden džihádista na pařížském předměstí dvěma řeznickými noži podřezal středoškolského profesora dějepisu a zeměpisu jen proto, že $v$ rámci kurzu o svobodě projevu svým studentům ukázal karikatury Charlie Hebdo. Rituální ohavnost svého zločinu vystupňoval tím, že nakonec odřezal hlavu od těla. Tento 18letý zločinec nepocházel ze severní Afriky, byl to Čečenec narozený v Moskvě, ${ }^{115}$ který měl statut uprchlíka. Ale jeho čin byl vyhodnocen jako zvláště odporný teroristický útok $s$ jasným džihádistickým motivem.

Proto prezident Macron ještě $v$ den bestiální vraždy zdůraznil dvě hlavní myšlenky. Především je to důraz na laický charakter státu, tedy oddělení náboženství od politiky. A za druhé je to odhodlání všemožně čelit džihádistickému obskurantismu, ${ }^{116}$ čímž se v rámci probíhající francouzské debaty zcela vymkl z rámce politicky korektních přístupů a ještě více se posunul na pozice kritických autorů.

109 Byl to velice uznávaný a oblíbený premiér, funkci opustil dne 3.7. 2020 a vrátil se na post starosty města Le Havre. Předpokládá se, že $v$ dohledné budoucnosti se bude ucházet a funkci prezidenta republikya bude opravdu silným kandidátem.

110 Protéger les libertés en luttant contre le séparatisme islamiste ...www.elysee.fr > emmanuel-macron , 2020/02/18 > pro... Retrouvez la conférence de presse du Président Emmanuel Macron à Mulhouse. 18 février 2020.

111 Edouard Philippe détaille son plan pour une immigration ...www.liberation.fr > france , 2019/11/06 , edouard-phi...

112 Emmanuel Macron, « le séparatisme islamiste » et les crispations de la Turquie, Le Monde, 12. 10. 2020..

113 Grégoire Poussielgue : Emmanuel Macron affiche sa fermeté sur la sécurité. Les Echos, 2 oct. 2020

114 Jean-Christophe Laurence : Le "séparatisme » dans le collimateur de Macron. La Presse, 11. 10. 2020.

115 Attentat de Conflans : neuf personnes en garde à vue, dont des parents d'élèves et des proches du meurtrier. Le Monde 17. 10. 2020.

116 Professeur décapité : «l'obscurantisme ne gagnera pas», dit Emmanuel Macron. www.vosgesmatin.fr , 2020/10/16 
Autor: Doc. PhDr. Jan Eichler, CSc., nar. 1952, po absolvování VA pracoval na MNO $\checkmark$ Praze, 1979-82 československé velvyslanectví v Pařiži. V 80. letech se zabýval vyhodnocováním vojenské politiky a ozbrojených sil Francie, 1991-94 Institut pro strategická studia. $V$ současné době pracuje v Ústavu mezinárodních vztahů v Praze, působí i na Fakultě mezinárodních vztahů VŠE Praha. Je autorem r̆ady učebnich textů a knih: War, Peace and International Security. From Sarajevo to Crimea, Palgrave, 2017, Od Hirošimy po Bělehrad; válka a mír v druhé polovině 20. století. Praha: Karolinum, 2014, Terorismus a války na počátku 21. století (Karolinum 2007). Mezinárodní bezpečnost $v$ době globalizace (Portál 2009), Bezpečnostní a strategická kultura USA, EU a ČR (Karolinum 2011), spoluautor publikace USA a Ruská federace - komparace z pohledu bezpečnostní a strategické kultury (ÚMV 2013). Vystupuje v rozhlase a televizi, publikuje vodborných časopisech, mj. Mezinárodní vztahy, Défense nationale, Relations Internationales et Stratégiques, Défense et stratégie (všechny tři Francie), OstEuropa (SRN), International Peacekeeping (Velká Británie), Studies in Conflict \& Terrorism, Communist and Post-Communist Studies (USA). Člen redakční rady Vojenských rozhledü. Člen vědecké rady FBMI ČVUT a oborové rady FBMI ČVUT, FSV UK a MUP.

Jak citovat: EICHLER Jan. Přistěhovalectví ve Francii a jeho bezpečnostní dopady. Vojenské rozhledy. 2020, 29 (4), 003-022. ISSN 1210-3292 (print), 2336-2995 (on-line). Available at: www.vojenskerozhledy.cz. 
Peer-reviewed

\title{
Defence strategies of the smaller NATO states - a comparative study
}

\section{Obranné strategie malých států NATO - komparativní studie}

\author{
Lukáš Dyčka, Taivo Rõkk, Zdzisław Śliwa
}

Abstract: Defence strategies of smaller NATO states represent interesting source of information about defence policies of this pool of countries. Definition of what constitutes "small state" is discussed in first step. In second step, this study compares 10 selected NATO countries Defence Strategies in terms of identified risks and threats, future military capabilities to counter threats, processes of drafting defence papers, level of details and approving authorities. Outlining these indicators and characteristics provide useful overview for future draft of National defence strategies within countries of similar size.

Abstrakt: Obranné strategie malých států NATO představují důležitý zdroj informací o obranné politice. Definice "malého státu" je však nejasná a její zpřesnění představuje první část článku. Ve druhé části pak text srovnává Obranné strategie deseti vybraných malých států NATO z pohledu hrozeb, budoucích vojenských schopností, procesu tvorby dokumentů, úrovně detailu a úrovně, na které je dokument schvalován. Přehledné seřazení těchto poznatků pak potenciálně může sloužit jako vhodný základ a inspirace při tvorbě obranných strategií menších států.

Key words: Defence; strategy; strategic documents; small states; military capabilities; NATO.

Klíčová slova: Obranná strategie; koncepční dokumenty; malý stat; vojenské schopnosti; NATO. 


\section{INTRODUCTION}

The re-emergence of the use of military power in the Eastern Europe after annexation of Crimea has again created a dilemma of making choices within defence policy of small states. It may be argued that this dilemma differs substantially from dilemmas faced by great powers and smaller states are often limited in their options. Obviously, small states are usually not powerful enough to be able to cope with their security environment by themselves. Therefore, their choices depend on geography, geopolitical setting, economic development, domestic conditions, membership of international organizations and even social cohesion ${ }^{1}$. Thus it often seems that their only possible survival strategy is for them is to resort to diplomacy, desirably in cooperation with other actors in order to avoid the risk of possible armed conflict ${ }^{2}$.

\section{Approaches and structure}

The authors of this paper focus on the defence strategies and required military capabilities for coming years in the context of threats as they are reflected in already existing strategic documents. Therefore, this paper is a comparative study of the National Defence Strategies of selected states in which indicators such as: threat perception, security environment, military challenges, capability development, defence budget etc. are assessed.

Within that framework, the aim of the paper is to recognize what is the smaller states' approach to defence strategies and their perception of development of armed forces capabilities. It is analysing the content and format of the defence strategy papers of the selected countries in the following research questions:

1. What are the identified risks and threats in selected nations defence strategy papers?

2. What are the characteristics of the future military capabilities to counter threats?

3. Do the respective state authorities use the non-governmental expertise (e.g. think tanks) during the process of drafting their defence papers?

4. On what defence strategy documents are based and what is level of details?

5. What national authorities are approving strategic documents?

6. The "Small NATO countries" for this analysis were chosen based on the criterion of population in the range between 1 million and below 10 million. That criterion refers specifically to Estonia, Latvia, Lithuania, Slovakia, Slovenia, Norway, Denmark, Bulgaria, Albania and Croatia. Some states such as Hungary, Czech Republic,

1 Vaicekauskaité, Živilè Marija. 2017. Security Strategies of Small States. Journal on Baltic Security. 0006, 2017, Vol. III, 2, pp. 7-15.

2 Gashi, Bejtush. 2016. Small States and National Security. SSRN. [Online] 6 August 2016. Available at: https://papers.ssrn.com/sol3/papers.cfm?abstract_id=2818984. 
Portugal or Greece are only slightly above the threshold of 10 million inhabitants, but comparing their military capabilities and postures, it may be argued, that within NATO context they no longer constitute "small state". Similarly, NATO states with less than 1 million inhabitants such as Montenegro, Luxembourg or Iceland may be for similar reason considered negligible. However, for the sake of better comparison, the term "small state" and the associate criteria will be elaborated more in depth in one of the subsequent chapter 1.

It is often complicated to understand to which document plays the role of "Defence strategy" in different states. For example, within the selected sample in this paper different countries are using the different names of their respective national defence papers: four countries use "defence strategies" $3,4,5,6$, three countries use the term "strategic defence review" 7,8,9 one country uses "military strategy"10, one country uses "defence agreement"11, and one country uses the term "defence concept"12. Most of the documents are available in English, but Slovak and Bulgarian are only in their national languages. For those two the translation program and native speakers' expertise was used. Moreover, Slovak strategy analysed in this paper is a draft which was not yet approved in Parliament. In addition, Estonian Defence strategy was adopted in 2010, although the security strategy was updated 2017. Despite that, the Defence strategy was still considered relevant in $2019^{13}$ and thus not renewed on purpose as it still describes the situation sufficiently. In addition to strategies, the relevant academic articles and specific questionnaires were used.

3 EESTI VABARIIGI KAITSEMINISTEERIUM. 2010. Riigikaitse strateegia.[National Defence Strategy]. Tallinn : Eesti Vabariigi kaitseministeerium, 2010.

4 MINISTRY OF DEFENSE OF THE REPUBLIC OF BULGARIA. 2016. National Defence Strategy. Sofia : Ministry of Defense of the Republic of Bulgaria, 2016.

5 MINISTRY OF DEFENCE OF THE REPUBLIC OF SLOVENIA. 2013. Defence Strategy of the Republic of Slovenia. Ljubljana : Ministry of Defence of the Republic of Slovenia, 2013.

6 MINISTRY OF DEFENCE OF THE REPUBLIC OF SLOVAKIA. 2019. National Defence Strategy of the Republic of Slovakia (draft version). Bratislava : Ministry of Defence of the Republic of Slovakia, 2019.

7 MINISTRY OF DEFENCE OF THE REPUBLIC OF ALBANIA. 2013. Strategic Defence Review of the Republic of Albania. Tirana : Ministry of Defence of the Republic of Albania, 2013.

8 MINISTRY OF DEFENCE OF THE REPUBLIC OF CROATIA. 2018. Strategic Defence Review. Zagreb : Ministry of Defence of the Republic of Croatia, 2018.

9 CHIEF OF DEFENCE. 2015. Strategic Defence Review. Oslo : Norwegian Armed Forces, 2015.

10 MINISTRY OF DEFENCE OF THE REPUBLIC OF LITHUANIA. 2016. The Military Strategy of the Republic of Lithuania. Vilnius : Ministry of Defence of the Republic of Lithuania, 2016.

11 THE DANISH GOVERNMENT (VENSTRE (THE LIBERAL PARTY), THE LIBERAL ALLIANCE AND THE CONSERVATIVES), THE SOCIAL DEMOCRATS, THE DANISH PEOPLE'S PARTY, THE SOCIAL-LIBERAL PARTY. 2018. Defence Agreement 2018-2023. Kopenhagen : The Goverment of the Kingdom of Denmark, 2018.

12 MINISTRY OF DEFENCE OF THE REPUBLIC OF LATVIA. 2012. The State Defence Concept. Riga : Ministry of Defence of the Republic of Latvia, 2012.

13 HEINSAR, Tarmo. 2019. Questionnaire. 1 December 2019. 
The study consists of four chapters. The first one discusses "what small states are", how to define them and what kind of approaches and dilemmas they usually face in international security environment. Second chapter analyses the different threats and risks identified in Defence strategies of small states and provides answer to the first research question. Identified threats naturally varied and were thus aggregated into the list of sixteen of them. With several of the most common, more detailed analysis is provided. Only the results are included within this chapter. For full list of threats, further methodology and scales see Table 2 at the end of the chapter 2 .

The third chapter analyses the challenges to development of military capabilities of the respective nations and provides comprehensive answer to the research question $n$. 2. The 1 to 5-point scale was used to analyse the states. Again, aggregating the (often very wide) approaches within respective states altogether eight different criteria were created.

Fourth paragraph then assesses the process of the formulation of the different strategies and thus focuses more on formal and procedural characteristics. By doing so it provides answers to the research questions n. 3, 4 and 5.

The reason for selecting aforementioned categories and criteria is twofold. Firstly, the idea to assess not only content but also the form of the documents was found to be important, because while content may change over time and is heavily case specific, it is the form, that arguably stays relevant in longer period. Secondly the criteria were selected based on extensive overview of relevant literature on similar topics ${ }^{14}, 15,16,17$. Presented list of categories could thus be considered as the usual set of characteristics that should be assessed during drafting of the future Defence Strategies.

\section{SMALL STATES - DEFINITIONS AND CRITERIA VS. CHALLENGES AND DILEMMAS}

The term 'small state' as such does not possess commonly recognized definition as it varies significantly in differing sciences or disciplines and it is described based on variety of criteria linked with specific focus of an area of studies. As such, the perception of what is small state is not stable and could evolve though years as some indicators could change significantly, e.g. GDP (compare Norway before oil boom and after); population

14 VUCETIC, Srdjan, et al. 2017. A Comparative analysis of Defence Review papers. Eidgenössische Technische Hochschule Zürich. [online] 2017. [cit. 2019-10-08] Available at: https://css.ethz.ch/en/services/digitallibrary/publications/publication.html/a8135eef-e0d3-4a43-b45e-d45509995963.

15 MCKEON, Celia. 2018. Contrasting Narratives. A comparative Study of European and North American National Security Strategies. [online] 2018. [cit. 2019-10-08] Available at: https://rethinkingsecurityorguk. files.wordpress.com/2018/03/contrasting-narratives-march-2018.pdf.

16 STOLBERG, Alan G. 2012. How Nation states craft National Security Strategy Documents. Army War College. [online] 2012. [cit. 2019-10-08] Available at: https://publications.armywarcollege.edu/pubs/2201.pdf

17 RICHTER, Jiří and Miroslav MAŠLEJ. Realizace strategické analýzy z pohledu zpracovatelů strategických dokumentů v AČR. Vojenské rozhledy. 2019, 28 (1), 016-029. 
(effect of aging or immigration/emigration) or size (mid-size Yugoslavia division into small nations; collapse of Soviet Union etc.). It was recognized by Mathias Maass as "despite the existence of a substantial specialized literature on small states and the existence of small states in large numbers, the phenomenon of the small state remains vaguely defined, by scholars as well as practitioners." ${ }^{18}$ Authors often mention the size and population as an indicator. The World Bank has organized a platform known as The Small States Forum (SSF) with some 50 nations characterized by small population, limited human capital, and a confined land area. It is recognizing microstates with population less than 200000 people and small states as those with population below $1.5 \mathrm{mln}^{19}$. The small are seen also as nations having between 1000,000 and $1.5 \mathrm{~m} / \mathrm{n}$ inhabitants ${ }^{20}$. The SSF nations (Figure 1) are very different in nature as of their population size, they are coming from different continents, they are possessing different size, some are islands or are landlocked but they see themselves within the category of small nations. Moreover, they differ as of their political system, GDP, economy and even some are fragile or failing countries. The American Heritage Dictionary is also recognizing the term 'microstate', also called 'ministate', as "an independent country that is very small in area and population" ${ }^{\mathbf{2 1}}$. There is debated straightforward way to define threshold between big and small states "for example, a population size of 15 million people, and a €GDP of 500 billion" and it is enabling "creating a clear and easily applicable definition of small states" 22 . Within the research related to small states Thorhallsson has recognized them as countries with "resident populations below 10 or 15 million" but even between 1 or 1,5 million ${ }^{\mathbf{2 3}}$. In that context, the term small state is very relative as e.g. Nepal $(28 \mathrm{mln})$ is small state in Asia, especially when compared to close neighbourhood, but in Europe it would be recognized as midsize if population is used as decisive criteria. It is worth mentioning, that population is not only limited to sheer numbers but it is also linked to demographic structure, number of representatives in international organizations, minorities, social cohesion, GDP per capita, size of armed forces and many other indicators impacting the position of the country, especially regionally. Among advantages of being 'small' is that the cohesion of society could be stronger, innovation among society and business could

18 Maass, Matthias. 2009. The elusive definition of the small state. International Politics Vol. 46, No 1, 2009.

19 The World Bank. 2019. Small States Home. Overview, The World Bank in Small States. [online] 2019. [cit. 2019-10-08] Available at: http://www.worldbank.org/en/country/smallstates/overview.

20 WIVEL, Anders; Bailes, Alyson; Archer, Clive. 2014. Setting the scene: small states and international security, in: Archer, Clive et al (eds). Small States and International Security. Europe and beyond. London : Routledge, 2014.

21 HOUGHTON MIFFLIN HARCOURT. 2016. American Heritage Dictionary of the English Language, Fifth Edition, Houghton Mifflin Harcourt Publishing Company. Houghton Mifflin Harcourt Publishing Company. [online] 2016. [cit. 2019-10-08] Available at: https://ahdictionary.com/word/search.html?q=microstate\&submit. $x=35 \&$ submit. $y=19$.

22 WIVEL, Anders; Bailes, Alyson; Archer, Clive. 2014. Setting the scene: small states and international security, in: Archer, Clive et al (eds). Small States and International Security. Europe and beyond. London : Routledge, 2014.

23 THORHALLSSON, Baldur. 2018. Studying small states: A review. Small States \& Territories, Vol. 1, No 1. 2018. 
be encouraged, during elections there is better knowledge about candidates within the population etc.

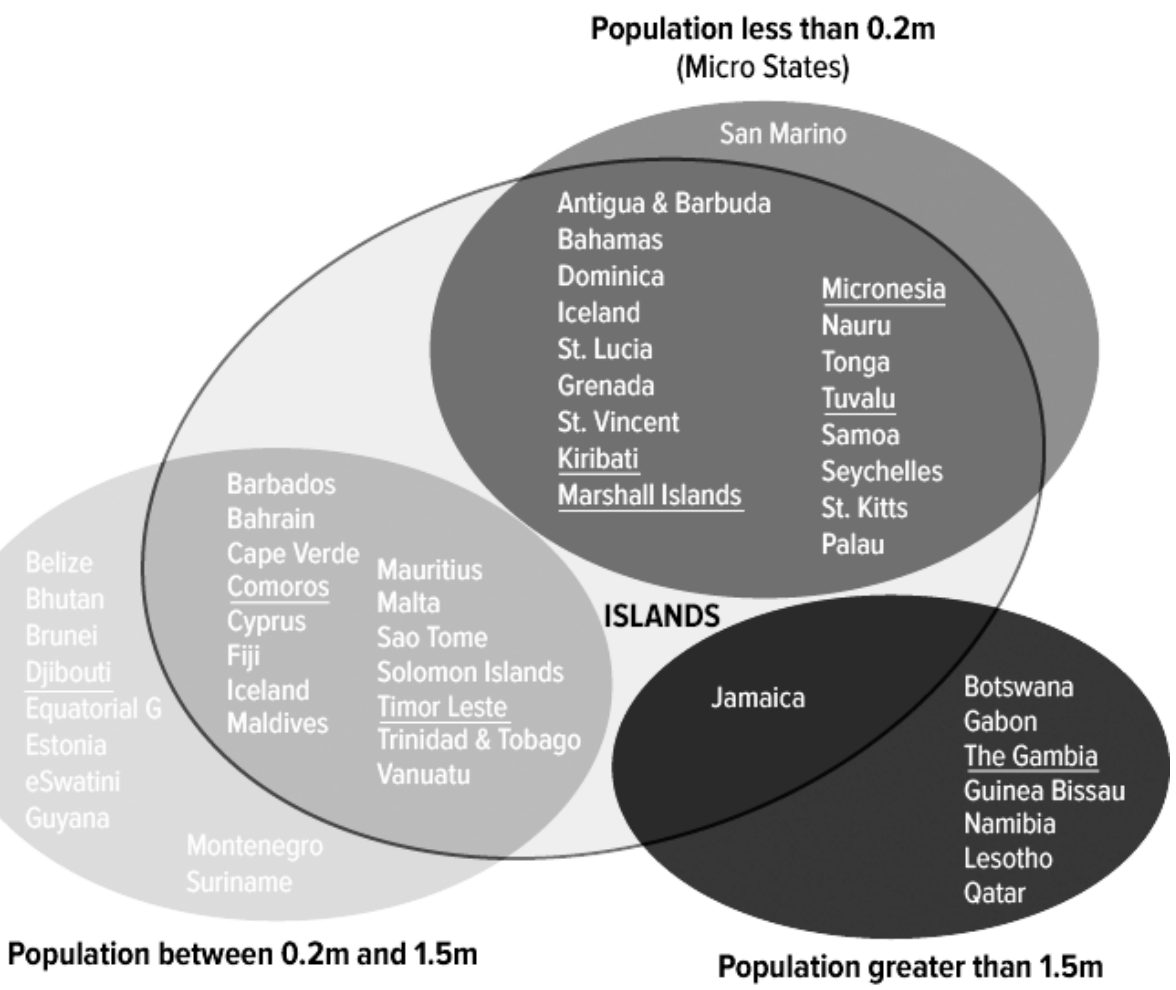

Note: Small States consist of Islands, land-locked states and coastal states. Those countries outside the inner circle for Islands are land-locked or coastal.

${ }^{* *}$ Countries underlined indicate FCVs that are classified as fragile according to the Harmonized List of Fragile Situations

Table 1: The nations of the Small States Forum ${ }^{24}$

As of genuine limitations, small nations tend to look into merging their political, economy or military capabilities to face potential threats. An example could the decisive drive of Estonia, Latvia and Lithuania, after their re-independence, to join a military alliance (NATO) and a political-economic federation (European Union) as guarantors of

24 THE WORLD BANK, 2019. Small States Home. Overview, The World Bank in Small States. [online] 2019. [cit. 2019-10-08] Available at: http://www.worldbank.org/en/country/smallstates/overview. 
their security ${ }^{25}$. The major reason was shared recognition of threat coming from Russian Federation based on their historical experiences. It is linked with regional identity of states. Another example in Europe is Visegrad Four or in Asia as Association of Southeast Asian Nations (ASEAN). Such approach is linked with nations' decision to use alliances for either balancing, bandwagoning or networking. The first option is joining an alliance with dominant power like USA "to avoid domination by stronger powers" to balance too strong influences posed by regional countries like Russia or China ${ }^{26}$. The bandwagoning is based on belief that "states will tend to ally with rather than against the dominant side"27 and it could be case of e.g. Belarus being united with Russia in Collective Security Treaty Organization. The networking is based on building joint international bodies by smaller nations creating synergy effect by synchronizing security efforts, to strengthen their voice on international fora, to coordinate military programs, and exchange information, etc. In this context, it could be argued, that the case of ASEAN, Visegrad Four or some common initiatives of three Baltic nations are based on strong desire "not to be bullied just because we're small"28.

Nevertheless, small state alone could have visible impact within some specific domain e.g. Switzerland on banking system ( $8.5 \mathrm{mln}$ people), Kuwait on oil market $(4.5 \mathrm{mln}$ citizens) or on regional security like Israel impact on the whole Middle East (9mln citizens). Such situation is causing a shift of discussion from just absolute numbers towards what is the real power small nations are exercising within specific domains of modern societies. It is a proof that even small nations being weak in specific aspects could be parallel powerful actors in other domains. Small nations could, alone or jointly, impact bigger organizations and EU can serve as solid example. It was recognized already in 2003, when facing 2004 enlargement, EU would "soon be dominated by states with populations of less than 10 million" 29 . As recognized by Geurts "small member states enjoy substantially more representation in all EU institutions that mere criteria of population entitle them to" ${ }^{\prime 30}$. The same is applicable towards NATO as decisions must be agreed by all the member states, allowing small nations to use that for their advantage ${ }^{31}$.

25 JURKYNAS, Mindaugas. 2014. Security concerns of the Baltic States in the twenty-first century, in: Archer, Clive et al (eds). Small States and International Security. Europe and beyond. London : Routledge, 2014.

26 WALT, Stephen. 1985. Alliance Formation and the Balance of World Power. International Security. Vol. 9, No. 4 Spring, the MIT Press, 1985.pp. 3-43.

27 Ibid.

28 HARDY, James. 2014. Analysis: ASEAN finds voice over South China Sea dispute. IHS Jane's Defence Weekly. London. [online] 14 August 2014. [cit. 2019-10-08] Available at: http://www.janes.com/article/42006/ analysis-asean-finds-voice-over-south-china-sea-dispute?utm_campaign=[PMP]_PC6110_E14\%20 DF\%20NL\%20SECURITY\%2008_19_2014_DW_Deployment\&utm_medium=email\&utm_source=Eloqua.

29 HEY, Jeanne. 2003. Introducing Small State Foreign Policy, in: Hey, Jeanne (ed.) Small States in World Politics. Explaining Foreign Policy Behaviour. London : Boulder, 2003.

30 GEURTS, Charles-Michel. 1998. The European Commission: A Naturally Ally of Small States in the EU Institutional Framework?, in: Goetschel, Laurent. Small States inside and outside the European Union. Interests and Policies. Boston, London : Kluwer Academic Publishers, 1998.

31 Vike-FREIBERGA, Vaira. 2018. Preface. Baltic Security at the Centenary: Democracies and Modernities, in: Spruds, Andris; Andzans, Maris, Security of the Baltic Sea Region Revisited amid the Baltic Centenary, The Riga Conference papers., Latvian Institute of International Affairs, 2018. 
The studies related to small states differ in criteria used, but small states are nevertheless important subject of international relations. One of the reasons it that as the global environment is evolving, processes such as globalization, internationalization, technological innovations, market economies, hybrid warfare, cyber warfare and informational pressure are making smaller states vulnerable ${ }^{32}$. This vulnerability could be enhanced even more by great powers who possess significant capabilities allowing them to pressure 'small states'. Thus, researching smaller nations' position in security environment is necessary for better understanding of the challenges they could face and also to understand how to use their limited capabilities and resources, to share their experiences coming from their history, to facilitate regional alliances based on shared threats and interests in many domains.

As has been already mentioned in the introduction, for the purpose of this study the concept of the small states is grounded solely on the population as a factor. This approach is linked with Europe as the focus continent as it is dominated by small states and the size of population to be considered is ranging between $1 \mathrm{mln}$. and $10 \mathrm{mln}$. Such approach is in line with other researches recognizing that "population size is the most common single variable in defining the size of states" and although GDP and territory are used the "territory and economy are not particularly useful on their own"33. The Authors are recognizing the complexity of defining the term 'small states' but the purpose is not to solve that terminology related aspect and it is rather aiming to have more practical value by looking into selected nations in the context of their defence strategies when facing commonly recognized challenges for their independence, territorial integrity and self-governance.

\section{THE POTENTIAL RISKS AND THREATS}

The most often mentioned threats within the selected list of small countries are asymmetric/hybrid threats (such as cyber-attacks, propaganda, etc) and a threat from military potential of non-state actors (including terrorism, extremism, and piracy). Hybrid threats were touched upon in all ten defence papers and threats coming from non-state actors were emphasized eight times. The first one indicates the Russian hybrid warfare in Ukraine ${ }^{34}$ and asymmetric actions in NATO's eastern border states ${ }^{35}$. Non-state threat may refer to fight with ISIS. The only country, which does not specifically mention terrori$\mathrm{sm}$ as a threat, is Estonia. These two threats are otherwise the only common categories.

32 THORHALLSSON, Baldur. 2018. Studying small states: A review. Small States \& Territories. Vol. 1, No 1. 2018. THORHALLSSON, Baldur. 2018. Studying small states: A review. Small States \& Territories. Vol. 1, No 1. 2018. RUKOMEDA, Roman. 2018. Russia's Hybrid War Against Ukraine: The Lates
Oslo : the Center for Integrity in the Defence Sector (CIDS Norway), 2018. 
Next categories indicate the differences between Baltic states and the rest of the group. Thus while Slovakia, Bulgaria, Slovenia and Croatia see threat of migration from the South as important, the Baltic States are more concerned with threat from Russia. Only Denmark is an exception, putting both of these threats forward. It is also interesting that Latvia is describing the Russian's threat in very detailed and straightforward way. Meanwhile Norway slightly surprisingly does not consider Russia as a direct threat, but indicates the possibility that country may end up in a conflict only because of geographical position near Russia's strategic nuclear weapons bases or in support of Allied forces according NATO Article $5^{36}$.

The other states are rather modest by their statements. Although Balkan countries do not see Russia as a direct threat, most of them still touch upon a conventional military threat. It makes sense, because some of the Balkan countries are afraid of threat from neighbouring countries, because of the historical legacy ${ }^{37}$.

Moreover, most of the Balkan countries as well as for example Slovakia considers proliferation of weapons of mass destruction (WMD) to be a serious threat. At the same time, Baltic States and Denmark do not mention this topic at all. The same applies to threats of natural and industrial disasters, and threat to energy security. Only Lithuania finds those two as a risk. Meanwhile, Estonia and Latvia should be much worried about the energy security because they are very dependant of Russia's gas. Could it be the case, that Tallinn and Riga are too much concentrated-on Russia and a hybrid warfare threats and because of that omit energy security?

In addition, there were several different threats and risks mentioned by single or couple of states. Such as: international organised crime by Latvia and Bulgaria; less effective armament treaties by Slovakia and Bulgaria; adversary states possessing much more advanced technology (mentioned by Slovakia and Croatia); regional crises by Lithuania and Albania; violation of international law by Slovakia; Arctic climate change and increased activity in High North by Denmark and Norway. This last threat is of growing importance in the future because of the large amount of raw materials: minerals, oil and gas. That could cause a world largest trade war ${ }^{38}$; and finally, health and epidemic threats were explicitly mentioned only by Slovenia. However, as bulk of this article has been written before Covid-19 pandemic in 2020, there is high chance, that this threat will increase in importance in next revision of strategic documents.

Overall the threat perception as reflected in the Defence Strategies is summarized in following Table 2.

36 CHIEF OF DEFENCE. 2015. Strategic Defence Review. Oslo : Norwegian Armed Forces, 2015.

37 NATION, Craig R. 2003. War in the Balkans, 1991-2002. Carlisle : U.S. Army War College, 2003.

38 NORD UNIVERSITET. 2018. An American Threat to the High North. High North News. [online] 2018. [cit. 2019-10-08] Available at: https://www.highnorthnews.com/en/american-threat-high-north. 


\begin{tabular}{|c|c|c|c|}
\hline No. & Category & Which countries see it as a risk/threat? & $\begin{array}{l}\text { Number } \\
\text { of states }\end{array}$ \\
\hline 1 & Threat from Russia & Estonia, Lithuania, Denmark, Latvia, Norway & 5 \\
\hline 2 & Threat from conventional military power & Slovakia, Latvia, Albania, Slovenia & 4 \\
\hline 3 & Threat from South - Migration/Refugees & $\begin{array}{l}\text { Slovakia, Bulgaria, Slovenia, Bul- } \\
\text { garia, Denmark, Norway }\end{array}$ & 6 \\
\hline 4 & Violation of International Law & Slovakia & 1 \\
\hline 5 & $\begin{array}{l}\text { Non-state actors military potential/ } \\
\text { Terrorism/Extremism }\end{array}$ & $\begin{array}{l}\text { Slovakia, Latvia, Lithuania, Bulgaria, Albania, } \\
\text { Slovenia, Croatia, Denmark, Norway }\end{array}$ & 9 \\
\hline 6 & International organised crime & Latvia, Bulgaria & 2 \\
\hline 7 & $\begin{array}{l}\text { Asymmetric and hybrid threats (cyber- } \\
\text {-attacks, propaganda, piracy etc.) }\end{array}$ & $\begin{array}{l}\text { Slovakia, Estonia, Latvia, Lithuania, Bulgaria, } \\
\text { Albania, Slovenia, Croatia, Denmark, Norway }\end{array}$ & 10 \\
\hline 8 & Less effective armament treaties & Slovakia, Bulgaria & 2 \\
\hline 9 & Adversary states are more advanced in technology & Slovakia, Croatia & 2 \\
\hline 10 & Proliferation of WMD & Slovakia, Bulgaria, Albania, Slovenia & 4 \\
\hline 11 & $\begin{array}{l}\text { Threat to the sovereignty of ne- } \\
\text { ighbouring countries }\end{array}$ & Slovakia & 1 \\
\hline 12 & Regional crises & Lithuania, Albania & 2 \\
\hline 13 & Threat to energy security/economic crises & Lithuania, Bulgaria, Albania, Latvia & 4 \\
\hline 14 & Natural and industrial disasters. & Lithuania, Bulgaria, Albania, Slovenia & 4 \\
\hline 15 & Health and epidemic threats & Slovenia & 1 \\
\hline 16 & $\begin{array}{l}\text { Arctic climate change and inc- } \\
\text { reased activity in High North }\end{array}$ & Denmark, Norway & 2 \\
\hline
\end{tabular}

Table 2: Threat perception in selected NATO countries

\section{CHARACTERISTICS OF THE FUTURE MILITARY CAPABILITIES}

To assess how small states perceive their future military capabilities, it was necessary to develop matrix for grading this vast sphere (see Table 3 below). Altogether following 8 different categories have been identified as relevant and assessed: 1) Conscription vs Regular forces/active duty, 2) Balanced development of armed forces services, 3) Territorial or Expeditionary forces, 4) Modernization of forces: conventional or innovative, 5) Decrease or increase of size of armed force, 6) Totally independent or Collective Defence (NATO), 7) Decrease or increase of defence budget: $2 \%$ in next decade, 8 ) Use of only military means or comprehensive approach to defence.

The 1 to 5-point scale was used (see Table 4 in Annex for detailed grading) to assess each of these categories for each state. Scale however do not have normative value. Instead, the value is given by using the approach where at one end the grade " 1 " is a more traditional approach and at the other end " 5 " is more progressive and innovative approach. 


\begin{tabular}{|c|c|c|c|c|c|}
\hline CRITERIA & 1 & 2 & 3 & 4 & 5 \\
\hline $\begin{array}{l}\text { Conscription vs Regu- } \\
\text { lar forces/active duty }\end{array}$ & $\begin{array}{l}100 \% \text { of } \\
\text { conscription }\end{array}$ & $\begin{array}{l}\text { Majority of } \\
\text { conscription } \\
\text { and minor of } \\
\text { regular forces }\end{array}$ & $\begin{array}{l}\text { Almost half } \\
\text { and half }\end{array}$ & $\begin{array}{l}\text { Majority of } \\
\text { regular and minor } \\
\text { conscription }\end{array}$ & $\begin{array}{l}100 \% \text { of } \\
\text { regular forces }\end{array}$ \\
\hline $\begin{array}{l}\text { Balanced develo- } \\
\text { pment of armed } \\
\text { forces services }\end{array}$ & $\begin{array}{l}100 \% \text { balanced: } \\
\text { navy, air, land } \\
\text { components }\end{array}$ & $\begin{array}{l}\text { Majority is } \\
\text { balanced and mi- } \\
\text { nor specialized }\end{array}$ & $\begin{array}{l}\text { Almost half } \\
\text { and half }\end{array}$ & $\begin{array}{l}\text { Majority is } \\
\text { specialized and } \\
\text { minor balanced }\end{array}$ & $\begin{array}{l}100 \% \text { of spe- } \\
\text { cialized in one } \\
\text { services only }\end{array}$ \\
\hline $\begin{array}{l}\text { Territorial or Expe- } \\
\text { ditionary forces }\end{array}$ & $100 \%$ territorial & $\begin{array}{l}\text { Majority is terri- } \\
\text { torial and minor } \\
\text { expeditionary }\end{array}$ & $\begin{array}{l}\text { Almost half } \\
\text { and half }\end{array}$ & $\begin{array}{l}\text { Majority is } \\
\text { expeditionary and } \\
\text { minor territorial }\end{array}$ & $\begin{array}{l}100 \% \text { of } \\
\text { expeditionary }\end{array}$ \\
\hline $\begin{array}{l}\text { Modernization of } \\
\text { forces: conventio- } \\
\text { nal or innovative }\end{array}$ & $\begin{array}{l}100 \% \\
\text { conventional }\end{array}$ & $\begin{array}{l}\text { Majority is } \\
\text { conventional and } \\
\text { minor innovative }\end{array}$ & $\begin{array}{l}\text { Almost half } \\
\text { and half }\end{array}$ & $\begin{array}{l}\text { Majority is inno- } \\
\text { vative and minor } \\
\text { conventional }\end{array}$ & $100 \%$ innovative \\
\hline $\begin{array}{l}\text { Decrease or increase } \\
\text { of size of armed force }\end{array}$ & $\begin{array}{l}\text { Major } \\
\text { Decrease }\end{array}$ & Decrease & $\begin{array}{l}\text { Maintaining } \\
\text { the same level }\end{array}$ & Increase & Major increase \\
\hline $\begin{array}{l}\text { Totally indepen- } \\
\text { dent or Collective } \\
\text { Defence (NATO) }\end{array}$ & $\begin{array}{l}100 \% \\
\text { independent }\end{array}$ & $\begin{array}{l}\text { Mainly } \\
\text { independent }\end{array}$ & Both & Mainly collective & $100 \%$ collective \\
\hline $\begin{array}{l}\text { Decrease or increase } \\
\text { of defence budget: } \\
2 \% \text { in next decade }\end{array}$ & No increase at all & $\begin{array}{l}\text { Increase, but } \\
\text { year not known }\end{array}$ & $\begin{array}{l}\text { Increase } \\
\text { planned in } \\
\text { next decade }\end{array}$ & Already $2 \%$ & More than $2 \%$ \\
\hline $\begin{array}{l}\text { Use of only military } \\
\text { means or compre- } \\
\text { hensive approach } \\
\text { to defence }\end{array}$ & $\begin{array}{l}100 \% \text { military } \\
\text { means }\end{array}$ & $\begin{array}{l}\text { Mainly military } \\
\text { means comple- } \\
\text { mented some } \\
\text { other officials }\end{array}$ & $\begin{array}{l}\text { Military + } \\
\text { certain state } \\
\text { institutions }\end{array}$ & $\begin{array}{l}\text { Military + all state } \\
\text { institutions }\end{array}$ & $\begin{array}{l}100 \% \\
\text { comprehensive }\end{array}$ \\
\hline
\end{tabular}

Table 3: Characteristics of the future military capabilities

\subsection{Conscription or regular forces}

As a first characteristics, "conscription versus regular forces" nexus was analysed. Six countries out of ten have abolished conscription altogether, therefore they rely on professional armed forces ${ }^{39}$. Compulsory service is still exercised in Estonia, Denmark, Norway and Lithuania. In addition, since 2013 it is mandatory also for female in Norway ${ }^{\mathbf{4 0}}$. Meanwhile, Lithuania re-established conscription in 2015 partially for the fear of Russian behaviour in Ukraine but also because of the need to fill the depleted ranks of professional units and at least initially due to inability to attract sufficient number of volunteers ${ }^{41}$. Es-

39 SOMMER, Theo. 2012. NATO no Longer Fits the Bill: We Need a More European Alliance. Hamburg : Edition Körber Stiftung, 2012.

40 THE STRAIT TIMES. 2016. Norway introduces compulsory military service for women, bunking them in mixed dorms with men. [online] 2016. [cit. 2019-10-08] Available at: https://www.straitstimes.com/world/ europe/norway-introduces-compulsory-military-service-for-women-bunking-them-in-mixed-dorms.

41 PALOWSKI, Jakub. 2015. Lithuania Reintroduces The Compulsory Military Service - Consent Of The Parliament. Defence24.com. [online] 20March2015. [cit.2019-10-08] Availableat:https://www.defence24. com/armed-forces/lithuania-reintroduces-the-compulsory-military-service-consent-of-the-parliament. 
tonia has a biggest conscription rate compared to active duty, while Denmark has minor compulsory service number ${ }^{42}$. However, all of the selected countries in their respective defence papers declare the use of reserve component. Either through mobilization (e.g. Baltic States, Norway and Denmark) or contracted reserve (e.g. Slovenia, Croatia).

At the same time, Baltic States have significant volunteer based military organizations. For instance, Latvia has one regular mechanized brigade and four voluntary infantry brigades. In addition, Estonia and Lithuania have significant number of volunteer-based units. Denmark uses their volunteers mostly for compulsory service ${ }^{\mathbf{4 3}}$ and Norway has rapid response Home Guard. Meanwhile, the Balkan States do not emphasize so much of the voluntary based military organization in their defence documents.

\subsection{Force package}

Secondly, the force package was analysed in a sense of balanced or specialized armed forces' services. Which means, either country has equally developed the different arms or some arms are better developed than the others are or some of the branches are missing completely. The result is that Estonia and Latvia are more specialized than the rest of the states by putting a lot of effort to army, while the navy and air force play a modest role. Lithuania is quite similar, but still tries to develop navy and air force more than other Baltic States. However, the Balkan States, Denmark and Norway are rather balanced by developing each service and different arms in their regular armed forces. In addition, Denmark and Norway put a lot of effort of developing their maritime domains.

Therefore, it appeared the states with larger regular forces are more balanced than the countries who rely on conscription and voluntary based organization. The improper balance of services or lack of some of them is causing significant shortcoming as of lack ability to plan and conduct joint operations. That shortcoming is requiring reliance on other NATO nations to deliver e.g. air force or navy capabilities. That is not to overcome as of limited military budget not allowing e.g. three Baltic nations to build any reasonable air force or navy.

\subsection{Territorial or expeditionary forces}

Thirdly, the territorial forces and expeditionary forces of the respective states were analysed. In a sense that either country develops more homeland defence forces or more expeditionary forces. It turned out that most of the countries have a same approach.

42 JÄRVENPÄÄ, Pauli. 2016. Preparing forn the Worst: Conscription and Reserve Forces in the Nordics. Tallinn: International Centre for Defence and Security, 2016.

43 JÄRVENPÄÄ, Pauli. 2016. Preparing forn the Worst: Conscription and Reserve Forces in the Nordics. Tallinn: International Centre for Defence and Security, 2016. 
Which is a majority of territorial units and minor expeditionary units. Denmark is the only exception by declaring most of their units to be deployable. Of course, all the other states have deployable units as well, but not bigger than up to battalion size unit. While Baltics and Balkans see the biggest threat to their sovereignty, the Denmark puts a lot of effort to contribute to Alliance and fighting abroad ${ }^{44}$. When Crown Prince Frederik visited Estonia on 12 April 2018, he said to Danish Enhanced Forward Presence (eFP) soldiers': 'The protection of the Kingdom of Denmark starts here, at the border of the NATO eastern flank ${ }^{45}$. Of course, it is clear the NATO eastern flank countries cannot deploy significant portion of forces abroad while the biggest threat is at their doorsteps. In 2008, Georgia had a bad experience when their infantry brigade was deployed to Iraq while Russia invaded their country ${ }^{46}$.

Meanwhile Norway sees itself as a contributor to international operations but concentrates geographically to their mainland and High North.

\subsection{Modernization of the armed forces}

Furthermore, modernization of the armed forces was analysed. Whether it is a conventional (e.g. procurement of battle tanks, fighting vehicles, heavy armament) or more innovative (e.g. development of cyber domain, drones, hi-tech capabilities). Most of the selected countries are rather conventional in their modernization projects. Regardless of the development of cyber defence domain, the majority of the project are conventional. The exceptions are Denmark, Norway and Slovenia who are in between of conventional and innovative modernization.

\subsection{Increase or decrease of the forces}

The next category is the foreseen increase or decrease of forces. It appears, that the majority of the countries ( 7 of them) will be maintaining the same level of the size of their force. Instead of increasing the size, they are investing in the quality: better training, more sophisticated equipment, and more sufficient command and control system. Meanwhile, three states have decided to increase the size of at least some elements of

44 MINISTRY OF FOREIGN AFFAIRS OF DENMARK. 2018. Denmark in Estonia. Ministry of Foreign Affairs of Denmark. Embassy of Denmark in Tallinn. [online] 2018. [cit. 2019-10-08] Available at: http://estland. um.dk/en/about-us/news/newsdisplaypage/?newsid=c5ca4452-5e4f-4166-9c90-b11443c3add5.

45 Shlapak, David A. and Johnson, Michael. 2016. Reinforcing Deterrence on NATO's Eastern Flank: Wargaming the Defense of the Baltics. Santa Monica, CA: RAND Corporation [online] 2016. [cit. 2019-1008] Available at: https://www.rand.org/pubs/research_reports/RR1253.html.

46 Ühtegi, Riho. 2013. Vene-Gruusia 2008. aasta sõjast viis aastat hiljem.[Of Russia-Georgian 2008 War Five Years Later] Diplomaatia. Rahvusvaheline Kaitseuuringute Keskus. [online] 2013. [cit. 2019-10-08] Available at: https://diplomaatia.ee/vene-gruusia-2008-aasta-sojast-viis-aastat-hiljem/. 
their armed forces: Croatia, Denmark and Estonia. Croatia has decided to increase its mobilised reserve force up to 20000 troops $^{47}$. Denmark is planning to establish 4000 reserve troops in high readiness who are in short notice are able to strengthen the standing forces. Moreover, up to 20000 troops can be mobilized from conscripts of Total Defence Force and from volunteers of the Home Guard ${ }^{48}$. Estonia has decided to increase annual size of conscripts from 3200 up to 4000 and mobilized reserve troops from 21 000 up to $25000^{49}$.

On the contrary, to others, Norway has decided to downsize their force package. For instance, cancellation of one brigade-unit, procurement and upgrade of tanks and abandoning of one Army camp. Moreover, fewer F-35 fighter-jets and navy assets will be procured compare to previous plan.

\subsection{Independent defence or collective defence}

Sixth criteria are total independent defence or NATO collective defence. Only the approach and principles were considered, not the size and credibility of the armed forces. All of the states declare to contribute to Alliance and use it as a defence pillar. Majority of states see their defence quite balanced having both, independent and collective, as a one whole. However, there are some exceptions as well. Croatia sees their defence mainly independent than collective. At the same time, Slovakia declares their defence mainly collective.

\subsection{Decrease or increase of the defence budget}

Seventh criteria are decrease or increase of the defence budget. The $2 \%$ target of GDP was agreed already in $2005^{50}$ and confirmed in Wales Summit 2014 to continue to reach the aim in 202451. It turned out, only Albania do not increase the defence expenditure. In addition, Norway's position is terms of percentage is unclear. In their defence review,

47 Croatia Week. 2014. Croatian Army to Send Out Call-Ups Again - 20,000 Reserves Wanted. [Online] 22 July 2014. [cit. 2019-10-08] Available at: https://www.croatiaweek.com/ croatian-army-to-send-out-call-ups-again-20000-reserves-wanted/.

48 The Danish Government, the Social Democrats, the Danish People's Party, the Social-Liberal Party. 2018. Defence Agreement 2018-2023. Kopenhagen : The Goverment of the Kingdom of Denmark, 2018.

49 Eesti kaitseministeerium. 2018. Eesti sõjaline kaitse 2026. Tallinn : Eesti kaitseministeerium, 2018.

50 Appathurai, James. 2006. Defence Ministers' Meeting 8 June 2006. NATO. [Online] 30 October 2006. . [cit. 2019-10-08] Available at: https://www.nato.int/docu/speech/2006/s060608m.htm.

51 NATO. Wales Summit Declaration Press Release . NATO. [Online] 2014. [cit. 2019-10-08] Available at: https://www.nato.int/cps/ic/natohq/official_texts_112964.htm. 
they estimate next 20-year period need of growth over 90 billion of NOK (Norwegian crown).

Meanwhile, Denmark and Slovenia will increase to $2 \%$, but the exact time is not stated. Bulgaria, Croatia and Slovakia will increase by year 2024. Lithuania already has $2 \%$, Estonia and Latvia more than $2 \%{ }^{52}$.

\subsection{Military means or comprehensive approach}

Finally, preference of using only military means or rather comprehensive approach to defence was analysed. It appeared that Norway, Slovenia and all Baltic States use $100 \%$ comprehensive approach according their defence papers. This means that all society is involved in defence and contributing while also involving seemingly non-military sectors of economy such as education, transportation etc. In addition, these countries plan to use all country's resources - either state owned or private ones for the defence of the sovereignty. On the other hand Albania, Slovakia, Bulgaria, Croatia and Denmark rely mostly on military means and capacities in their National Defence Strategies.

In addition, all Baltic States emphasize the important role of the host nation support (HNS) system in order to receive allied troops and provide sufficient logistic support. No others mention HNS at all.

\section{PROCESS OF FORMULATING STRATEGY PAPERS}

\subsection{The use of non-governmental organizations}

Firstly, the following question was answered: do the state authorities use the non-governmental organizations (NGOs) expertise (e.g. think tanks) or input to draft their defence strategies? Short questionnaire was used to get the answers from respective experts. Seven answers were received out of nine questioned countries. The approach of Bulgaria and Denmark remain unknown. Estonia ${ }^{53}$, Latvia ${ }^{54}$, Lithuania ${ }^{55}$ and Croatia ${ }^{56}$ do not use non-governmental agencies directly. Although Estonia has an expertise of think

52 NATO Public Diplomacy Division. Defence Expenditure of NATO Countries (2011-2018). Brussels : NATO HQ, 2019.

53 Heinsar, Tarmo. 2019. Questionnaire . 01 April 2019.

54 Kuda, Maris. 2019. Questionnaire. Tartu, 15 March 2019.

55 Koroliovas, Paulius. 2019. Questionnaire. Tartu, 11 March 2019.

56 Baric, Robert. 2019. Questionnaire. 28 March 2019. 
tank, such as International Centre for Defence and Security Studies, it has been never used for drafting strategies. Lithuania does not use NGOs directly, but emphasizes the influence of different defence related studies by the think tanks. For instance, the RAND Corporation study called 'Reinforcing Deterrence on NATO's Eastern Flank: Wargaming the Defence of the Baltics' ${ }^{57}$. Croatia admits the absence of national non-governmental expertise. The government relies on the state institutions and agencies as all above named countries ${ }^{58}$.

On the other hand Albania ${ }^{59}$, Slovenia ${ }^{60}$, Norway ${ }^{61}$ and Slovakia ${ }^{62}$ use a NGOs input and expertise while drafting and developing their defence strategies.

Albania, while drafting the strategy, used the input of Albanian Institute for International Studies and Institute of Democracy and Meditation. In Slovenia, the defence strategy was drafted in the Ministry of Defence, but by a broad civil-military expert working group. The designated experts in various fields used analysis of NGOs, such as: climate change, migration issues, public opinion on security, demographic trends etc. Once the draft document was ready, it was sent to the public: universities, interest groups, military veterans and so on. The document proposal was publicly accessible on the government portal and accessible to all (including NGOs) to respond to it and give their views. The next step was to gather all these opinions at the Ministry of Defence and to define them and prepare the final (harmonized) version of the defence strategy for consideration and acceptance. $^{63}$

In Norway, the Defence Forces are responsible of drafting the strategic defence review. Also, the Defence Research Establishment is involved, although it is not NGO. Norsk Utenrikspolitisk Institutt (NUPI) is one of the most important NGOs, which has been used for drafting defence papers. ${ }^{64}$

Finally, Slovaks have pushed it even further. Non-governmental and the academic community was widely used. For instance, Association of Security and Defence Industries and several independent experts. Public discussions were held, including negotiations with selected representatives of the non-governmental professional community. More than four dozen non-governmental and academic actors were addressed in this debate. ${ }^{65}$ The full and exact overview is presented in Annex Table 5.

57 Koroliovas, Paulius. 2019. Questionnaire. Tartu, 11 March 2019.

Baric, Robert. 2019. Questionnaire. 28 March 2019.

Toci, Çlirim. 2019. Questionnaire. 18 February 2019.

Vuk, Pavel. 2019. Questionnaire. 15 February 2019.

Helseth, Hans. 2019. Questionnaire. Tartu, 17 April 2019.

Dovhun, Ladislav. 2019. Questionnaire. 31 March 2019.

Vuk, Pavel. 2019. Questionnaire. 15 February 2019.

64

Dovhun, Ladislav. 2019. Questionnaire. 31 March 2019. 


\subsection{Basis and the level of details of the defence strategy documents}

Most of the defence strategy papers are based on national security strategies, seven out of ten: Estonia, Bulgaria, Croatia, Denmark, Slovenia, Slovakia and Lithuania. In addition to security strategy, Bulgaria and Lithuania mention also the National Constitution. Albanian defence paper also touches upon Constitution, but the main basis is National Strategic Concept. Croatia and Latvia are the only countries whose defence papers are derived by national law. Meanwhile, Norway do not have so called security strategy. They use a white paper called "Setting the course for Norwegian foreign and security policy".

Moreover, all of the countries mention NATO for several times, but only two countries clearly declare their defence papers are in line of NATO Strategic Concept. Full list is presented in Annex Table 6.

Next, the level of details was analysed. One to five scale was used to assess different defence papers. Grade 1 is the very general and on the other end, 5 is very detailed (see Annex Table 7). It appeared the most detailed is Albanian paper and received the highest grade. It describes the whole process of developing defence review. Provides planning assumptions and parameters, national interests, strategic threat assessment and level of ambition. It also touches upon the budget areas and estimates the economic development and support of the armed forces for years 2013-2020. The paper also gives detailed overview of budgetary requirements, operational capabilities and resource allocation to support the force. One whole chapter is dedicated to future force capabilities: defence planning methodology, armed forces planning scenarios and situations, capabilities and requirements of the future force, future structure and future force calendar implementation.

The next ones were Latvia and Denmark, which both had rather detailed papers, which were well structured, and most of the defence related figures were introduced. Latvian paper provides the following: security environment, basis of national defence, state's capacities, armed forces tasks and capabilities, defence budget, personnel plan and the role of military industry. Denmark's defence agreement adds the areas such as: contribution to NATO and activities against terror attacks.

Five countries received average result. Croatian, Slovenian, Slovakian, Norwegian and Lithuanian papers are in average detail level, providing the basic structure and basic figures. Furthermore, the most general papers belong to Bulgaria and Estonia. Their papers provide basic principles and little figures. The summary of the results is provided in Annex Table 8.

\subsection{The adaptation level of the defence strategy papers}

The current study looked on which level the different papers are adopted (for summary see Table 9 in Annex). It turned out the majority of the strategies are adopted by Government or Council of Ministers, that both are considered the same level. These 
countries are Albania, Bulgaria, Croatia, Slovenia, and Estonia. Two of the strategies, Latvian and Slovak, are adopted by the Parliament. In Lithuanian case, the minister of defence approves their national military strategy. Furthermore, Denmark is the exception because they have defence agreement, which is adopted by all political parties in Parliament. But still, the paper itself is drafted in Ministries of Defence.

Moreover, Norway's defence review is also exception, because it is drafted in Armed Forces and approved by Chief of Defence.

However, Denmark and Norway are the only kingdoms while the other eight states are parliamentary republics. Despite that, all ten states have rather similar political system where heads of the states (including a king) have mostly ceremonial role, parliament is legislative and government (led by a prime minister) executive body.

In addition, adoption is the final stage of the drafting hierarchy. There are usually lot of work and interaction between different officials and in some cases in society as well. For instance, in Slovenia, when the draft defence strategy was carried out, it was forwarded to the government for consideration, and at the same time, it was sent to the public (universities, interest groups, military veterans' associations, etc.). The document proposal was publicly accessible on the government portal and accessible to all to respond it and give their views. The next step was to gather all these opinions at the Ministry of Defence and to define them (or harmonize) and prepare the final (harmonized) version of the defence strategy for consideration and acceptance by the Government of the Republic of Slovenia. Prior to adoption, the government also briefed the parliamentary defence committee on the document. ${ }^{66}$

\section{CONCLUSION}

If aggregating the findings from comparison of Defence strategies of ten small NATO states, it appears that the most common threats are asymmetric and hybrid threats such as: cyber-attacks, propaganda, terrorism, extremism, and piracy. All ten countries also see state-based hybrid activity as a threat. It is because of the Russian hybrid warfare in Ukraine and asymmetric actions in NATO's eastern flank. Russian threat is biggest concern to Estonia, Latvia and Lithuania, while Slovakia, Bulgaria, Slovenia and Croatia consider migration from South riskier than Russia question. Denmark, as an exception, considers both threats equally.

Furthermore, The Balkans are worried of the conventional military threat from neighbouring countries because of the history of Balkan Wars. The Balkans also consider the proliferation of weapons of mass destruction as a threat as well. Meanwhile, Baltics, Denmark and Norway do not mention that at all. Energy security is also an issue for Balkans and Lithuania, but not for Estonia and Latvia. It seems that Tallinn and Riga are much more concerned about Russia's conventional threat and it is linked with their Russian speaking minorities. In addition, Norway is highly concerned about High North

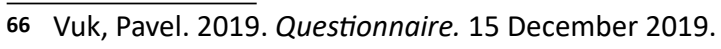


resources and Russia's activity in that region. Arctic possess a variety of natural minerals and raw materials and this can easily launch large-scale trade war.

It turns out the risks and threats are not driven by size, culture or military capabilities. It is a geopolitical situation. Those who share border with Russia, consider it as a threat and those who face the refugees, consider migration as an imminent threat.

Interestingly pandemics were seen as rather minor threat and were mentioned only in single case. How this perception will change in post-2020 revisions of strategic documents remains to be seen, but it may be expected, that priority of health-related issues will rise in prominence significantly.

However, countries try to counter the threat and risks by developing military capabilities. Different characteristics were analysed. Such as, developing conscription or regular forces; force package; territorial or expeditionary forces; modernization of the armed forces; increase or decrease of the forces; totally independent or collective defence-oriented forces; decrease or increase of the defence budget and comprehensive approach to defence.

It appeared the six countries out of ten have abolished conscription. Compulsory service is still in place in four of them. However, all of the selected ten countries in their respective defence papers declare the use of reserve component.

When it comes to force package, then it turned out, Estonia and Latvia are more specialized, putting a lot of effort to land component of armed forces. While the Balkans, Denmark and Norway are more balanced. It may be the case that Baltic States cannot afford balanced approach and putting the effort to land domain, because they cannot compete with Russia's Anti-Access/Area Denial (A2/AD) capabilities anyway. Instead, they are investing to land forces in order to avoid countries' annexation as long as the Allies will arrive and introduce the enablers what Baltic States are missing, such as: air power, sea control, air defence, rocket artillery etc. Meanwhile, Balkans do not face the imminent threat from Russia and they look for more balanced options in order to be ready for terrorism, migration, piracy or perhaps threat from neighbouring countries (e.g. Croatia vs Serbia).

Furthermore, most of the countries develop homeland defence forces rather than expeditionary forces. The only exception is Denmark which declares most of its units to be deployable. Also, majority of armed forces modernization is rather conventional than innovative. The exceptions are Denmark, Norway and Slovenia, which are in between of conventional and innovative modernization. For small and not very rich countries, it is not so easy to be innovative because usually the budget is rather limited. Moreover, in a changed security situation everybody wants to be sure they have first of all initial self-defence capability. On the other hand, all of the countries declared asymmetric and hybrid warfare the threat. It may be expected to put more effort to hi-tech and innovative developments. Of course, it could be also the case that public defence papers do not reflect all the modernization projects. Especially the hi-tech developments are usually restricted.

It may be expected, that in a changing security environment, most of the countries look for increase of the forces, but actually majority maintaining the same level. Only Croatia, Denmark and Estonia are increasing the force. Croatia because of the threat from neighbouring countries and their war history, Estonia because of the threat of 
Russia and increasing defence budget, and Denmark because of seeing itself as a contributor of NATO's eastern flank as part of their forward national defence. Norway is the only state increasing their forces because of the defence budget issues. Instead, they are trying to increase the quality of the force.

In addition of their own forces, all of the selected countries rely in NATO collective defence and Article 5 of the Washington Treaty. Majority of the countries defence capabilities are quite balanced, having independent armed forces being ready to contribute to collective defence as one of core tasks of NATO. There are some exceptions, such as Croatia could be perceived as focusing more on independent approach and Slovaks more on collective defence. All of them are recognizing the importance of Article 3 requiring building national and collective capabilities of armed forces to resist any attack against their sovereignty.

In order to maintain the force each nation needs a credible defence budget. Baltic States have already reached to 2\%, Bulgaria, Croatia and Slovakia will increase by year 2024 . Meanwhile Denmark and Slovenia will increase to $2 \%$, but the exact time is not known. Albania is not going to do so and Norway's position remains unclear. The $2 \%$ of the GDP has been an issue for a long time, becoming more and more important, and having a direct political impact. The US has clearly stated that there must be shared burden and everybody has to reach at least $2 \%$. The question is, would it be enough or should we look more of amount of money and capabilities available instead of pure math.

In the process of formulation of their defence strategy papers, only Albania, Slovenia, Norway and Slovakia use the input of non-governmental organizations, such as different think-tanks and research organizations. Some countries do not have that expertise at all (e.g. Croatia) and some have, but do not use (e.g. Estonia). Also, some countries even ask a public and academic opinion (e.g. Slovakia).

Mostly, the respective defence papers are based on national security strategies and security concepts. In some countries (Albania, Croatia, Latvia) it is mandatory by law. The level of details varies from very detailed to rather general. The most detailed are Albanian, Latvian, Denmark's and most general Estonian and Bulgarian. Rest of the countries were average.

Lastly, it turned out most of the defence papers are adopted at Government level. Some by Parliament and some by Ministry of Defence. Interesting exception is Norway where adoption is carried out in Armed Forces, not in political level. It also appeared that defence papers are divided between different documents and their position in the document hierarchy is not always the same. 


\section{ANNEX}

Table 4: Results of Challenges to Military Capabilities in 1-5 scale

\begin{tabular}{|c|c|c|c|c|c|c|c|c|c|c|c|}
\hline No & CRITERIA & ALB & BUL & CRO & DNK & SVN & SVK & EST & LVA & LTU & NOR \\
\hline 1 & $\begin{array}{l}\text { Conscription vs Regular } \\
\text { forces/active duty }\end{array}$ & 5 & 5 & 5 & 4 & 5 & 5 & 2 & 5 & 4 & 3 \\
\hline 2 & $\begin{array}{l}\text { Balanced or Spe- } \\
\text { cialized forces }\end{array}$ & 1 & 1 & 1 & 1 & 3 & 2 & 4 & 4 & 3 & 1 \\
\hline 3 & $\begin{array}{l}\text { Territorial or Expe- } \\
\text { ditionary forces }\end{array}$ & 2 & 2 & 2 & 4 & 2 & 2 & 2 & 2 & 2 & 4 \\
\hline 4 & $\begin{array}{l}\text { Modernization of } \\
\text { forces: conventio- } \\
\text { nal or innovative }\end{array}$ & 2 & 2 & 2 & 3 & 3 & 2 & 2 & 2 & 2 & 3 \\
\hline 5 & $\begin{array}{l}\text { Increase or dec- } \\
\text { rease of force }\end{array}$ & 3 & 3 & 3 & 4 & 3 & 3 & 4 & 3 & 3 & 4 \\
\hline 6 & $\begin{array}{l}\text { Totally indepen- } \\
\text { dent or Collective } \\
\text { defence (NATO) }\end{array}$ & 3 & 3 & 2 & 3 & 3 & 4 & 3 & 3 & 3 & 3 \\
\hline 7 & $\begin{array}{l}\text { Decrease or increase } \\
\text { of defence budget }\end{array}$ & 1 & 3 & 3 & 2 & 2 & 3 & 5 & 4 & 4 & 2 \\
\hline 8 & $\begin{array}{l}\text { Use of only military me- } \\
\text { ans or comprehensive } \\
\text { approach to defence }\end{array}$ & 2 & 4 & 3 & 3 & 5 & 3 & 5 & 5 & 5 & 5 \\
\hline 9 & $\begin{array}{l}\text { HNS system inclu- } \\
\text { ded or not }\end{array}$ & 1 & 1 & 1 & 1 & 1 & 1 & 5 & 5 & 5 & 1 \\
\hline & TOTAL & 20 & 24 & 22 & 25 & 27 & 25 & 32 & 34 & 31 & 26 \\
\hline
\end{tabular}

Table 5: Utilization of the non-governmental expertise (e.g. think-tanks) to draft defence strategies

\begin{tabular}{|c|c|c|c|c|c|c|c|c|c|}
\hline ALB & BUL & CRO & DNK & SVN & SVK & EST & LVA & LTU & NOR \\
\hline Yes & - & No & - & Yes & Yes & No & No & No & Yes \\
\hline
\end{tabular}

Table 6: The basis of national defence papers

\begin{tabular}{|c|c|c|c|c|c|c|}
\hline State & $\begin{array}{c}\text { Security } \\
\text { Strategy/Policy }\end{array}$ & $\begin{array}{c}\text { Law of National } \\
\text { Security }\end{array}$ & $\begin{array}{c}\text { National } \\
\text { Constitution }\end{array}$ & $\begin{array}{c}\text { NATO Strategic } \\
\text { Concept }\end{array}$ & $\begin{array}{c}\text { National Stra- } \\
\text { tegic Concept }\end{array}$ & Defence Law \\
\hline ALB & & & $\mathrm{x}$ & & $\mathrm{x}$ & \\
\hline BUL & $\mathrm{X}$ & & $\mathrm{x}$ & $\mathrm{X}$ & & $\mathrm{x}$ \\
\hline CRO & $\mathrm{X}$ & & & & & \\
\hline DNK & $\mathrm{X}$ & & & & & \\
\hline SVN & $\mathrm{X}$ & & & & & \\
\hline
\end{tabular}




\begin{tabular}{|c|c|c|c|c|}
\hline SVK & $x$ & & & \\
\hline LVA & & $x$ & & \\
\hline LTU & $x$ & & $x$ & $x$ \\
\hline EST & $x$ & & & \\
\hline NOR & $x$ & & & \\
\hline
\end{tabular}

Table 7: The level of details of the respective defence papers in 1-5 scale

\begin{tabular}{|l|l|l|l|l|}
\hline \multicolumn{1}{|c|}{1} & \multicolumn{1}{|c|}{$\mathbf{2}$} & $\mathbf{3}$ & \multicolumn{1}{c|}{$\mathbf{4}$} & \multicolumn{1}{c|}{$\mathbf{5}$} \\
\hline $\begin{array}{l}\text { Very general, only } \\
\text { basic principles. No } \\
\text { specific figures }\end{array}$ & $\begin{array}{l}\text { General, basic } \\
\text { principles, some } \\
\text { specific figures }\end{array}$ & $\begin{array}{l}\text { Average, between } \\
\text { general and detailed }\end{array}$ & $\begin{array}{l}\text { Detailed, structu- } \\
\text { red, most of the } \\
\text { figures introduced }\end{array}$ & $\begin{array}{l}\text { Very detailed, } \\
\text { a lot of specific } \\
\text { figures: budget, } \\
\text { deadlines, force sizes, } \\
\text { procurement plan, } \\
\text { development plan }\end{array}$ \\
\hline
\end{tabular}

Table 8: The results of the level of details in 1-5 scale

\begin{tabular}{|c|c|c|c|c|c|c|c|c|c|}
\hline ALB & BUL & CRO & DNK & SVN & SVK & LVA & LTU & EST & NOR \\
\hline 5 & 2 & 3 & 4 & 3 & 3 & 4 & 3 & 2 & 3 \\
\hline
\end{tabular}

Table 9: Level of adoption of the defence strategy papers

\begin{tabular}{|c|c|c|c|c|c|}
\hline State & $\begin{array}{l}\text { Ministry of } \\
\text { Defence }\end{array}$ & $\begin{array}{l}\text { Political } \\
\text { Parties }\end{array}$ & $\begin{array}{l}\text { Government/ } \\
\text { Council of } \\
\text { Ministers }\end{array}$ & Parliament & Chief of Defence \\
\hline ALB & & & $x$ & & \\
\hline BUL & & & $x$ & & \\
\hline CRO & & & $x$ & & \\
\hline DNK & & $x$ & & & \\
\hline SVN & & & $x$ & & \\
\hline SVK & & & & $x$ & \\
\hline LVA & & & & $x$ & \\
\hline LTU & $x$ & & & & \\
\hline EST & & & $x$ & & \\
\hline NOR & & & & & $x$ \\
\hline
\end{tabular}


Author: $\quad$ Lukáš Dyčka, PhD, holds PhD in political science with specialization on security and strategy studies from Masaryk University in Brno. In April 2013 he started working at the Centre for Security and Military Strategic Studies, University of Defence, in the Czech Republic where he specialized in Czech Defence Policy and Armed Conflict Research. Between 2014 - 2016 he also worked as an Advisor at the Czech MoD. In June and July 2017 he was posted to the Defence Planning Department of the Hungarian MoD. In 2017 he received the Eisenhower Fellowship from the NATO Defence College in Rome. Currently, besides other positions, he also lectures at the Baltic Defence College in Estonia.

LTC Taivo Rõkk, MA., has studied in Estonian Military Academy officers' bachelor course in 1998-2001 and masters course in 2008-2010. He has also graduated Baltic Defence College's Joint Command and General Staff Course in 2014 and Higher Command Studies Course in 2019. He has served in different positions in Estonian Defence Forces, such as a battalion commander, brigade 54 and different staff officers positions in Joint HQ. As of now, LTC Rõkk holds the position of Head of the Logistic Department in HQ of Estonian Defence Forces.

Zdzisław Śliwa, PhD, is dean of the Baltic Defence College, and a visiting professor of Latvian National Defence Academy. He completed his education among others in: the Polish National Defense University in Warsaw (1996), the US Army Command and General Staff College, Fort Leavenworth, Kansas (2000), USA and in the Center of Strategic Studies of the People's Liberation Army National Defense University, Beijing, China (2008). He served as the Chief of Operational Branch J-3 in KFOR Headquarter in Kosovo and the Chief of Operational Planning Branch J-5, Polish Armed Forces Operational Command in Warsaw. He was working for Polish military educational institutions, including the National Defense University in Warsaw. He has published books and papers related to regional and international security.

How to cite:DYČKA, Lukáš, Taivo RÕKK and Zdzisław ŚLIWA. Defence strategies of the smaller NATO states - a comparative study. Vojenské rozhledy. 2020, 29 (4), 023-045. ISSN 1210-3292 (print), 2336-2995 (online). Available at: www.vojenskerozhledy.cz 
Recenzovaný článek

\title{
Analýza dynamiky konfliktu v Mali - využití databáze ACLED
}

\section{Analysis of the Malian conflict dynamics \\ - exploiting ACLED database}

\author{
Jan Kofroň, Michal Opletal, Matyáš Zrno
}

Abstrakt:_ Cílem článku je demonstrovat možnosti využití databáze „Armed Conflict Location \& Event Data Project" pro analýzu vnitrostátních konfliktů na př́kladu současného Mali. Na makro-úrovni článek zejména analyzuje geografické šíření konfliktu a jeho základní kvantitativní charakteristiky (počty obětí různých typů incidentů). Na mikro-úrovni se pak zaměřuje na region Mopti a kromě základní geografické distribuce analyzuje interakce jednotlivých ozbrojených skupin působících v oblasti.

Abstract: Focusing on current Malian conflict, the aim of the article is to demonstrate usefulness of the "Armed Conflict Location \& Event Data Project" database for the analysis of intra-state conflicts. At the macrolevel the paper analyzes geographical spread of the conflict and its key quantitative characteristics (numbers of fatalities stemming from different types of incidents). At the micro-level it focuses on Malian region Mopti. At this level the paper analyzes geographical distribution of various incidents and the interaction of the key armed groups operating within the region.

Klíčová slova: Mali; Islamistické milice; ACLED; konflikt; kvantitativní analýza.

Key words: Mali; Islamist militias; ACLED; Conflict; Quantitative analysis. 


\section{ÚVOD}

AČR letos převzala velení výcvikové mise v Mali ${ }^{1}$ a Ize čekat, že i v dalších letech bude $v$ této oblasti působit. Konflikt v Mali je svým charakterem konfliktem přeshraničním, nebot' do velké míry zasahuje i Burkinu Faso a zčásti i Niger. Byl-li dříve konflikt tažen zejména rozpory mezi Tuaregy a vládou, v současnosti se posunul i do roviny náboženské, kdy hlavní protivládní síly akcentují islamistickou ideologii. ${ }^{2}$ Působení v takto komplexním prostředí vyžaduje mimo jiné i kvalitní analytické podklady.

Text řeší dva související cíle. Na obecné rovině ukazuje možnosti (a omezení) databáze „Armed Conflict Location \& Event Data Project“ (ACLED) 3 jakožto jedné z hlavních databází pokrývajících násilné incidenty nejen v Africe. Přitom průběžná aktualizace databáze umožňuje její využití i pro tvorbu např. čtvrtletních či měsíčních přehledů vývoje bezpečnostní situace. Na substantivní rovině - jakožto praktickou ilustraci možností a limitů ACLED - text analyzuje základní trendy bezpečnostní situace v Mali (sekundárně i Burkině Faso a Nigeru) od roku 2015.

Na své substantivní rovině text řeší tři hlavní otázky: (i) jaký je kvantitativní vývoj různých typů násilných událostí v průběhu posledních pěti let, (ii) kteři aktéři se dostávají do konfliktu, (iii) a jak se jeví taktické kompetence Malijské armády a jejích hlavních protivníků ve vybraných střetech. První dvě otázky budou řešeny jednak na celkové úrovni všech tři států a jednak pro vybraný regionu Mopti (region s největším počtem násilných událostí). Poslední otázku budeme řešit podrobnější analýzou vybraných větších střetů povstalců s armádou.

$K$ datové analýze využíváme RStudio a zejména balíček ggplot $2^{4}$. Tento volně dostupný software pro datovou analýzu nabízí tisíce baličků pro různé typy statistických analýz, grafické komunikace výsledků atd. ${ }^{5}$ Oproti tradičním produktům (SPSS, či MS EXCEL) nefunguje na principu „klikání“ v grafickém rozhraní, nýbrž přes kódování. Kódování sice staví překážku pro nováčky, umožňuje však mimořádnou replikovatelnost analýz. $\checkmark$ prípadě aktualizace dat (či řešení typově podobné situace) netřeba psát kód znovu.

1 ŠIMÍČEK,Jakub.ČešipřevzaliveleníevropskýmsilámvýcvikovémisevMali.In:Ministerstvoobrany, informační servis[online].Jun12,2020[cit.2020-08-01]. Dostupnéz:http://www.mise.army.cz/informacni-servis/ zpravodajstvi/cesi-prevzali-veleni-evropskym-silam-vycvikove-mise-v-mali-221930/

2 TOBIE, Aurélien. Central Mali: Violence, Local Perspectives and Diverging Narratives. SIPRI Insights on Peace and Security [online]. 2017, No. 5. [cit. 2020-08-01]. Dostupné z: https://www.sipri.org/sites/ default/files/2018-02/sipriinsight_1713_mali_3_eng.pdf

3 ACLED. Dashboard. [online]. C2020 [cit. 2020-08-01]. Dostupné z: https://acleddata.com/\#/ dashboard

4 WICKHAM, Hedley (2016). ggplot2: Elegant Graphics for Data Analysis. Springer-Verlag New York. ISBN 978-3-319-24277-4, https://ggplot2.tidyverse.org.

5 Rozsah článku neumožňuje hlouběji diskutovat R. Základní vhled do vizualizace dat v R nabízí HEALY, Kieran. Data visualization: a practical introduction. New Jersey: Princeton University Press, [2019]. ISBN 978-0-691-18162-2. Pro širší úvod do R vizí WICKHAM, Hadley a Garrett GROLEMUND. R for data science: import, tidy, transform, visualize and model data. Sebastopol: O'Reilly Media, [2017]. ISBN 1491910399. 
Stačí spustit kód s novými daty a program vygeneruje všechny kódem předdefinované výstupy.

Krom úvodu a závěru má text tři části. V první části je představena databáze ACLED, v druhé je provedena základní deskriptivní kvantitativní analýza konfliktu a ve třetí jsou prezentovány možnosti vytěžení informací databáze ACLED pro získání informací stran taktické situace. V př́lohách jsou k dispozici výchozí data, R kód, který Ize použít pro replikaci našich výstupů (např. kdykoliv po aktualizaci ACLEDu) a reaktivní HTML tabulku s jedenácti největšími střety mezi vládními silami a povstalci. Př́lohy jsou k dispozici pouze ve webové verzi článku.

\section{DATABÁZE ACLED, STRUKTURA, POKRYTí A OMEZENÍ}

ACLED je v jedno až dvoutýdenních intervalech aktualizovaná databáze, shromažd'ující údaje o politickém násilí, protestních událostech, a důležitých politicko-strategických aktech jednotlivých aktérů. Informace sahají až k roku 1997. Původně se databáze zaměřovala jen na Afriku, nyní pokrývá přes 100 zemí. Následující řádky, není-li řečeno jinak, vycházejí z codebooku ACLED. 6

Politické násilí je v rámci databáze definováno jako užití síly určitou skupinou/aktérem za účelem dosažení politických cílů a motivací. Aktér/účastník politického násilí je definován jako koherentní organizovaná skupina, jejíž akce nejsou nahodilé a oddělené, ale tvoří ucelený celek sledující určitý politický cíl (změna režimu, získání území aj.). Tato definice umožňuje dlouhodobě trasovat jednotlivé operace, ale i vývoj a charakteristiku aktérů. Výjimku (stran organizovanosti) představují demonstranti a civilisté. Demonstranti jsou chápáni jako spontánní skupina v rámci jedné události, jejiž organizovanost může a nemusí přetrvat. Civilisté jsou chápáni jako neorganizovaní a nedobrovolní účastníci konfliktní události.

Informace o událostech jsou sbírány z různého typu médií - od tradičních médií jako tiskové agentury, národní a lokální média, přes sociální sítě a zprávy mezinárodních institucí či neziskových organizací - až po lokální spolupracovníky v konfliktní zóně. Preferovanými zdroji jsou zejména lokální média a místní spolupracovníci. Proces ověření informací je trojstupňový, kdy je informace nejprve dekódována do standardního systému atributů, poté ověřována a porovnána s dalšími událostmi, a v posledním kroku validována. Každý krok provádí nezávislý výzkumník. Informace o konfliktní události publikované médii mohou být ze své povahy v okamžiku vzniku jednostranné a nepřesné. Odhady obětí se mohou posléze měnit ve světle nových informací. Databáze ACLED je tedy živou databází, kde veškeré informace uložené v databázi jsou revidovány, ověřovány a zpřesňovány objeví-li se nové informace. Upozorněme však, že ani to nezaručuje

6 ACLED, (2019). "Armed Conflict Location \& Event Data Project (ACLED) Codebook." Dostupné z: $\quad$ https://www.acleddata.com/wp-content/uploads/dlm_uploads/2017/10/ACLED_ Codebook_2019FINAL_pbl.pdf 
přesnost údajů. I jinak důvěryhodné instituce mohou vykazovat (např. politické) zaujetí v reportování, či důrazu na ověřování průběhu incidentů.

Základní atomickou jednotkou databáze je jedna konfliktní událost, která je ohraničena v prostoru a čase. Základní časovou jednotkou je právě jeden den. Trvá-li nějaká událost více dní, je tato v rámci databáze rozdělena na jednotlivé dny, kdy docházelo ke střetům. Obdobně, dochází-li v určité širší oblasti k více událostem najednou (např. série bombových útoků) pak je tato množina rozdělena do jednotlivých dílčích událostí. Jediným případem, kdy dochází k agregaci událostí, je pokud dílčí událost vznikla v důsledku hlavní události, např. "collateral damage" (v průběhu bojů dojde k zabití civilistů). Tato událost není kódována jako samostatný akt násilí na civilistech, ale oběti jsou zahrnuty do hlavní události kódující ozbrojený střet mezi dvěma bojujícími stranami. Ve srovnání s obdobnými databázemi jako je „Uppsala Conflict Data Program - Georeferenced Event Dataset (UCDP-GED), Social Conflict Analysis Database (SCAD) a Global Terrorism Database (GTD), ACLED obsahuje největší množství unikátních záznamů. Dle analýzy Dunforda a kol. ${ }^{7}$ se záznamy ACLED oproti ostatním databázím liší s variabilním objemem překryvu, který se liší dle států a let. ACLED neobsahuje značné množství ozbrojených konfliktů uvedených v UCDP a GTD, stejně tak neobsahuje nenásilné konflikty uvedené $v$ databázi SCAD. Totéž platí i obráceně, kdy uvedené databáze neobsahují záznamy uvedené v ACLED. Rozdíl je dán odlišnou metodologií, sběrem dat a zaměřením dílčích databází. SCAD mapuje nenásilné konflikty s vyšší granularitou než ACLED (zahrnuje i stávky apod.). GTD mapuje události definované jako teroristický akt. UCDP mapuje ozbrojené střety, kdy došlo ke zraněním či ztrátám na životě a událost je definována jako ucelená perioda, nikoliv disagregovaná na jednotlivé dny (jak činí ACLED). Analýza Dunforda a kol. všech záznamů pro Afriku v letech 1997-2016 (cca 133000 pozorování) ukazuje, že ACLED trpí cca 5\% duplicitou záznamů.

Hlavními proměnnými sledovanými databází ACLED je typ konfliktní události, aktéři události a vztah mezi nimi, místo a čas události a počet obětí. S cílem zachytit charakteristiky politického násilí konaného jednotlivými aktéry v dané oblasti, ACLED sleduje jak násilné konflikty, tak i občanské nepokoje a demonstrace. Jednotlivé kategorie se dále člení na nižší subkategorie $\mathrm{k}$ postřehnutí dílčích charakteristik. K zachycení důležitých strategických momentů ve vývoji konfliktu je politické násilí doplněno o důležité nenásilné momenty jako uzavírání smluv a aliancí.

Další sledovanou proměnou jsou aktéři. Databáze eviduje tisíce individuálních aktéru od ozbrojených a teroristický skupin přes státní či privátní složky po různé etnicko-politické skupiny. U každé události jsou (ideálně) uvedeni oba hlavní aktéři a jejich typ. Databáze rozlišuje pomocí číslovek 1-8 základní typy aktérů: 1 = státní složky, 2 = povstalecké skupiny, 3= politické milice, 4=etnické/identitární milice, 5=výtržníci , 6 = Protestující 7 = civilisté, 8 = externí aktéři (př. mezinárodní jednotky). Toto číselné kódování budeme dále používat v grafických výstupech. Aktér bývá někdy doplněn o tzv. "associate actor", které bud' více specifikuje aktéra, nebo identifikuje jeho spoluúčastníky. Tento způsob

7 DUNFORD, E., D. CUNNINGHAM, K. DONNAY a E. MCGRATH. An Integrated Picture of Conflict [online]. 2019. Dostupné z: http://www.davidcunninghampolisci.com/uploads/4/2/9/7/42974855/dunford_et_ al._integration.pdf 
kódování umožňuje sledovat jak jednotlivé aktéry, tak jejich časté spojence a oponenty. Rozdělení aktérů do osmi základních kategorií usnadňuje analýzy kooperace a konfliktu různých ozbrojených skupin. Nevýhodou databáze je, že explicitně nerozlišuje mezi útočníkem a obráncem, protože zprávy, ze kterých vychází, mohou být politicky zabarvené.

Čas události je uveden s přesností na den. U každé události je uvedena i přesnost, s níž bylo o události referováno. Rozlišují se tři stupně přesnosti. 1) Událost je známa s přesností na den, 2) s přesností na týden či víkend, nebo 3) se odehrála v průběhu konkrétního měsíce. Události s nižší přesností nejsou do databáze zahrnuty. Není-li znám přesný den, je událost zaznamenána pro střed intervalu.

Místo události je uvedeno s přesností na konkrétní lokalitu, doplněnou o vyšší administrativní celky. Lokalitou je míněno konkrétní město, vesnice, čtvrt' či orientační bod v krajině. Vedle určení místa se uvádí i přesnost určení. Obdobně jako u času je trojstupňové. 1) Zpráva hovoří o konkrétní vesnici, městu či georeferencovatelném místu, 2) je znám jen nejbližší významný bod ("u vesnice", "pobliž křižovatky"), 3) událost se odehrála v širší oblasti (př. region Mopti). Lokalita je vždy doplněna o souřadnice lat/lon ve WGS84, které Ize využít pro vynesení na mapu, nelze je však vztáhnout k přesnému místu střetu. Maximální možná přesnost určení místa události ( $v$ českém kontextu) je totiž základní sídelní jednotka. Upozorníme, že $\mathrm{Eck}^{8}$ ve své analýze poukázal na problém s geografickou přesností. Pro datasety Alžír 1997 a Burundi 2000 vykazoval ACLED podezřele vysokou míru maximální geografické přesnosti u událostí v rurálních oblastech. Dále zjistil vysokou míru chybně georeferencovaných záznamů u měst stejných jmen.

Jak ukazuje graf 1 v našem prípadě velké množství bojů, explozí i násilí proti civilistům vykazuje přesnost 2 . stupně. To sice znamená, že výše zmíněný problém s nadsazováním přesnosti zřejmě nebude př́tomný, zároveň je tento fakt třeba zohledňovat při pokusech o detailní analýzy úzce vymezených území.

8 ECK, Kristine. In data we trust? A comparison of UCDP GED and ACLED conflict events datasets. Cooperation and Conflict [online]. 2012, 47(1), 124-141 [cit. 2020-08-01]. DOI: 10.1177/0010836711434463. ISSN 0010-8367. Dostupné z: http://journals.sagepub.com/doi/10.1177/0010836711434463 


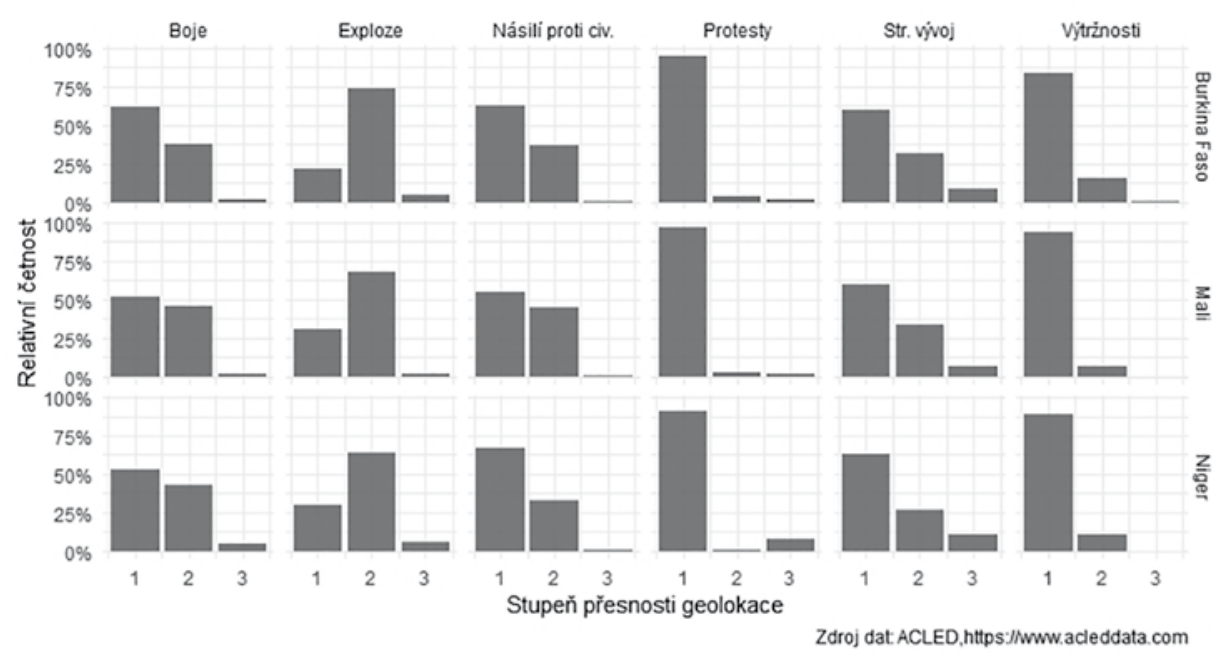

Graf č. 1: Přesnost geolokace typů incidentů v datasetu (Mali, Burkina Faso, Niger 2015-6/2020)

Významným, ale často nepřesným, ukazatelem je počet obětí. Informace o počtu obětí ve zdrojových zprávách můžou být nepřesné, ba i záměrně zmanipulované. Počty zraněných nejsou zahrnovány. Pro odhad jsou brány v úvahu zdroje, které jsou v dlouhodobém horizontu považovány za spolehlivé - z nich je převzata nejumírněnější hodnota. Ta však ve světle nových informací může být upravena kterýmkoliv směrem. $V$ prípadě vágní formulace počtu obětí (tj. desítky, stovky) je brána nejnižší hodnota (zde 10 a 100). Neobsahuje-li zdrojová zpráva počet, ale jen obecnou zmínku, pak je proveden odhad na základě charakteru události. Došlo-li k závažné události (např. letecká puma zasáhla budovu v rezidenční oblasti), pak se hodnota stanovuje na 10 . Pokud se jedná o minoritní událost, např. střet mezi fulbskou a dogonskou milicí, pak se hodnota stanovuje na 3. Uvádí-li zdroj počty obětí pro časový úsek delší jednoho dne, oběti se rozpočítají na jednotlivé dny. Počty obětí je tedy nutno nahlížet kriticky, to platí zejména u menších událostí, které mohou být jen těžko ověřeny.

\section{ANALÝZA KONFLIKTU}

Níže představená analýza konfliktu se zaměřuje na tři klíčové oblasti: (i) vývoj počtu a závažnosti násilných událostí (zde zejména s důrazem na boje ${ }^{9}$, exploze, a násilí proti civilistům), (ii) proměně jejich geografické distribuce a (iii) identifikaci interakcí hlavních

9 ACLED však definuje boje ("Battles") velmi široce. Často tak je tě̌̌ké rozlišit banditismus od vojenské činnosti. 
aktérů. V první části se zaměříme na makro-regionální úroveň (úroveň nejvyšších regionálních jednotek), a to pro období mezi 1. 1. 2015- 30. 6. 2020. Ve druhé části se zaměříme na vytipovaný malijský region Mopti (coby př́klad mimořádně konfliktního regionu), s časovým horizontem omezeným na období 1. 7. 2019 - 30. 6. 2020.

\subsection{Trendy konfliktu, makroregionální pohled}

Mali, jakož i řada dalších států v oblasti Sahelu, se dlouhodobě potýkalo s bezpečnostními problémy. ${ }^{10}$ Jejich vyvrcholením v poslední dekádě bylo povstání Tuaregů (2012), ti však byli záhy vytlačeni islamistickými skupinami a nebýt rychlého francouzského zásahu (leden 2013), pravděpodobně by došlo k pádu centrální vlády. ${ }^{11} \mathrm{~V}$ tuarežských oblastech se podařilo situaci stabilizovat, od roku 2017 se ale (jak dále ukážeme) rozhořel konflikt zejména v centrálních oblastech Mali, kde se prolíná etnická dimenze (Fulbové proti Dogonům) s dimenzí politicko-náboženskou (vláda proti islamistickým skupinám).

Jak ukazuje schematická mapa 1, od roku 2017 výrazně narostly počty násilných událostí. Toto platí zejména pro kategorie boje, exploze, a násilí proti civilistům. Distribuce těchto tří typů násilných aktivit se koncentruje do několika klíčových regionů. Právě $v$ těchto regionech dochází i $k$ nejvýraznějšímu nárůstu střetů v posledních letech. Je patrné, že v průběhu let se posouvá geografické těžiště konfliktu. Ten se nyní nachází ve středním Mali, v oblastech u hranic s Burkinou Faso a v oblasti Liptako-Gourma, kde se stýkají hranice Mali, Burkiny a Nigeru. Do těchto sousedních zemí se konflikt postupně šírí a momentálně již zasahuje velkou část Burkiny Faso. Boje, exploze i násilí proti civilistům se odehrávají v týchž oblastech (na rozdíl např. od protestů). Schematické mapy také jasně ukazují, že počet násilných událostí typu „boje“ a „násilí proti civilistům“ výrazně překračuje počty pro ostatní kategorie.

Podstatné je, že incidenty i jejich závažnost výrazně roste ve všech třech klíčových kategoriích - bojích, explozích i násilí vůči civilistům. Stručně řečeno, bezpečnostní situace se $v$ posledních letech dramaticky zhoršuje a to ve všech třech sousedících státech. Je však třeba zdůraznit, že v př́padě Nigeru existuji dvě konfliktní ohniska. První, na jihozápadě země, které má prímou spojitost s konfliktem v Mali (a Burkině Faso) a druhé, na

10 Pro širší kontext bezpečnostní situace v Sahelu viz např. EIZENGA, Daniel. Long term trends across security and development in the Sahel. West African Papers [online]. 2019, No. 25 [cit. 2020-08-01]. Dostupné z: https://doi.org/10.1787/630477ee-en.; Analýzu prístupu Mali k severním regionům poskytuje např. BALDARO, Edoardo. A Dangerous Method: How Mali Lost Control of the North, and Learned to Stop Worrying. Small Wars \& Insurgencies [online]. 2018, 29(3), 579-603 [cit. 2020-08-01]. DOI: 10.1080/09592318.2018.1455323. ISSN 0959-2318. Dostupné z: https://www.tandfonline.com/ doi/full/10.1080/09592318.2018.1455323

11 HEISBOURG, François. A Surprising Little War: First Lessons of Mali. Survival [online]. 2013, 55(2), 7-18 [cit. 2020-08-01]. DOI: 10.1080/00396338.2013.784458. ISSN 0039-6338; EICHLER, Jan, Operace Serval 2013: Nasazení francouzské armády v Mali. Vojenské rozhledy, 2013, roč. 22 (54), č. 2, s. 133-149, ISSN 1210-3292 (print), 2336-2995 (on-line) [cit. 2020-08-01]. Dostupné z: www.vojenskerozhledy.cz 
východě země u hranic Nigérií, které má spojitost s nigerijským konfliktem a skupinou Boko Haram. ${ }^{12}$
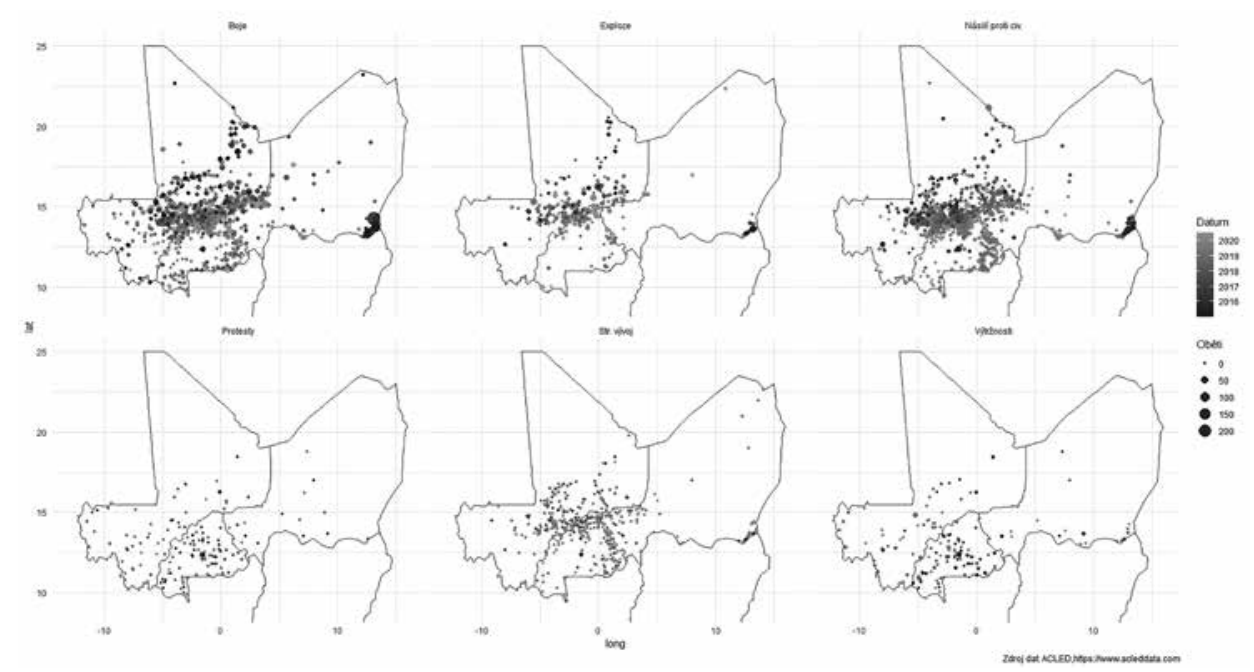

Mapa č. 1: Vývoj násilných událostí, Mali, Burkina Faso a Niger (2015-6/2020)

Celkové počty databází zachycených obětí násilných událostí zachycuje graf 2. Z pohledu dynamiky konfliktu vystupují tři klíčové aspekty. $V$ první řadě dramaticky roste počet obětí. Zopakujme, že údaje pro rok 2020 jsou pouze za jeho první polovinu a Ize tedy předpokládat, že do konce roku 2020 dojde k výraznému nárůstu počtu obětí ve sledovaných kategoriích a tedy výraznému překonání loňských čísel (prakticky ve všech sledovaných kategoriích). Ostatně již v polovině roku došlo v kategorii „boje“ k přibližnému vyrovnání počtu obětí z loňského roku. Druhým výrazným aspektem je masivní nárůst obětí v Burkině Faso v letech 2019 a 2020. To dokumentuje přelití konfliktu i do této, předtím relativně klidné, země. Třetím poměrně zajímavým aspektem je relativně malý počet obětí v důsledku explozí. Tento fakt ukazuje na to, že konflikt má překvapivě „kontaktní " povahu. To může být dáno několika faktory. Za prvé, geografické podmínky v oblasti sice umožňuji využití např. IED, motorová vozidla se však po většinu roku díky terénním podmínkám nutně nemusí držet cest, což snižuje efektivitu těchto prostředků. Zároveň slabost vládních sil umožňuje povstalcům mnohdy i poměrně sebevědomou formu boje. Roli hraje i malý počet osob v řadách teroristických skupin schopných sestrojit IED stejně jako nedostatek komponent pro jejich výrobu. Finálně, nemalá část bojů (jak ještě ukážeme dále) se odehrává mezi lokálními milicemi, pro jejichž cíle nemá využití

12 MACEACHERN, Scott. Boko Haram, bandits and slave-raiders: identities and violence in a Central African borderland. Canadian Journal of African Studies / Revue canadienne des études africaines [online]. , 1-17 [cit. 2020-08-01]. DOI: 10.1080/00083968.2019.1700142. ISSN 0008-3968. Dostupné z: https://www. tandfonline.com/doi/full/10.1080/00083968.2019.1700142 
IED obdobného významu jako pro povstalce bojující proti centrální vládě či mezinárodním jednotkám. V neposlední řadě graf dokumentuje, že jakkoliv protesty a nepokoje mohou mít významný politický dopad, v případě zkoumaných zemí jsou, co se týče počtu prímých obětí, marginální.

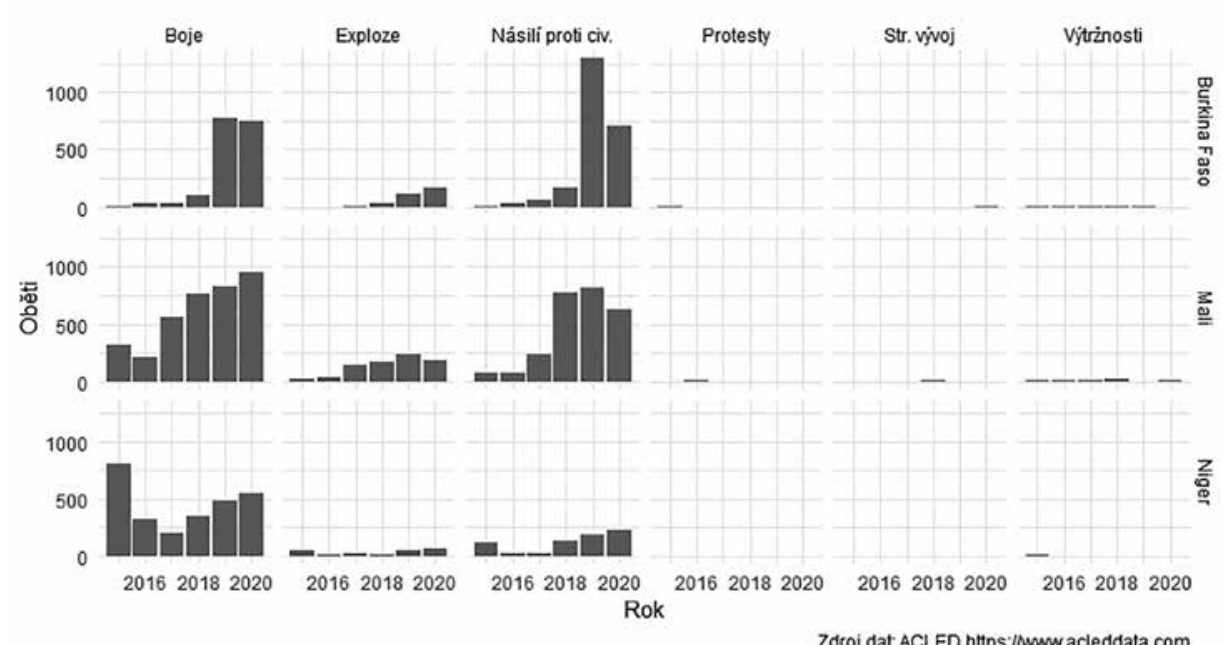

Graf č. 2: Oběti násilných událostí Mali, Burkina, Niger (2015-6/2020)

Jak jsme však již naznačili výše, uvnitř všech tří zemí existuje výrazná regionální diferenciace konfliktu. $Z$ celkového počtu třiceti nejvyšších administrativních regionů tří námi analyzovaných států je drtivá většina obětí koncentrována do dvanácti z nich (přičemž region Diffa leží na jihovýchodě Nigeru a tamní konflikt nemá přímou spojitost s malijským konfliktem). $V$ ostatních regionech se počet obětí pohyboval v posledních třech letech v řádu nízkých desítek. Jak ukazuje graf 3 jednoznačně nejnásilnějším regionem je v posledních třech letech Malijské Mopti a Burkinský Sahel. V obou regionech je výrazný počet obětí bitev, ještě větší počet obětí ale padá na vrub prímému násilí vưči civilistům. Uvážíme-li, že populačně je region Sahel zhruba poloviční oproti Mopti (cca 1,5 vs. 2,5-3 miliony obyvatel), Ize říci, že je zde intenzita násilí v posledním roce dokonce vyšší. 


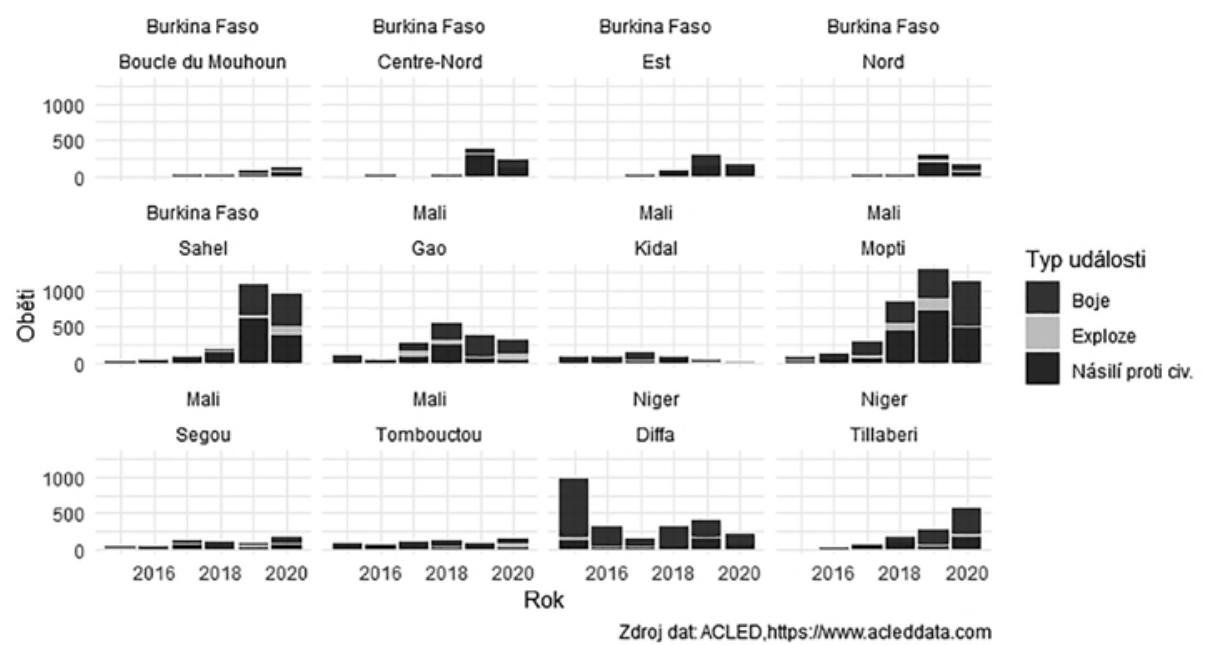

Graf č. 3: Regiony s největším počtem obětí

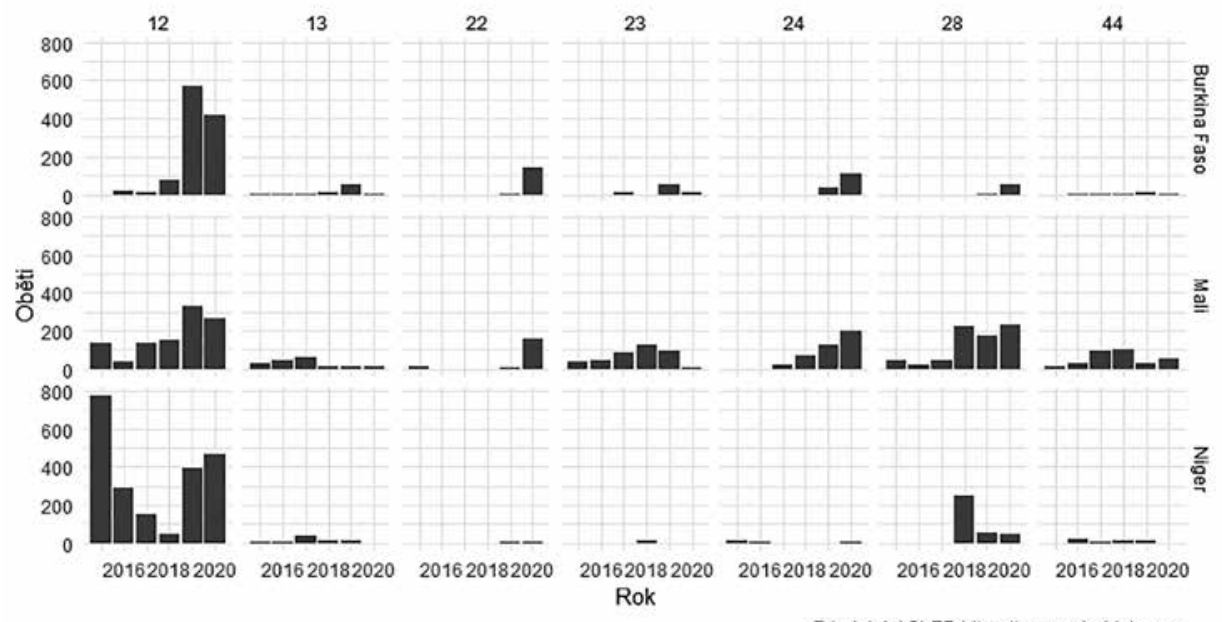

Zdroj dat:ACLED,https:I/Nww.acleddata.com

Graf č. 4: Typy aktérů bojů

Specifikem vnitrostátních konfliktů je jejich vyšší míra komplexnosti, kde nepřátelské interakce nejsou omezeny pouze na provládní síly a jejich odpůrce. Graf 4 proto sumarizujeme interakce hlavních typů aktérů a to pro dvě kličové kategorie (boje a násilí na civilistech), což jsou i kategorie s nejvyšším počtem obětí. $V$ případě bojů vyvstává několik zajímavých momentů. Dlouhodobě je vidět výrazná interakce vládních sil a islamistických povstalců (kód 12), stejně jako interakce mezinárodních sil a povstalců (kód 28). Ostatní 
typy interakcí jsou výrazně slabší, přičemž ale není nepodstatné, že zjevně dochází k neprátelským kontaktům i mezi povstaleckými silami a lokálními milicemi (které mnohde suplují roli vládních sil). Za nový, potenciálně významný, jev Ize považovat masivní narůst obětí nepřátelských interakcí mezi islamistickými skupinami (kód 22) v roce 2020. Tento vznikající rozkol v řadách islamistických skupin má přirozeně velký strategický potenciál (za předpokladu, že jej centrální vlády dokáží zužitkovat).

Druhá klíčová kategorie - násilí proti civilistům - však ukazuje na několik znepokojivých aspektů (viz graf 5). Nejen, že výrazně roste počet obětí díky útokům povstaleckých sil a lokálních milic, rostl i počet civilních obětí usmrcených státními silami (zejména v př́padě Burkiny Faso se situace v posledním roce vyhrotila). Specificky se jedná o násilí proti Fulbům, kteří tvoří velkou část příslušníků i sympatizantů islamistických skupin. ${ }^{13}$ Je tedy pochopitelné, že fulbské komunity budou v centru pozornosti vládních sil, stejně tak je ale pochopitelné, že tam, kde bude docházet $\mathrm{k}$ nepřiměřenému násilí ze strany vládních sil, dojde v lepším případě, $\mathrm{k}$ dalšímu podkopání ochoty ke spolupráci postižených komunit. $V$ horším případě budou tyto komunity ještě více náchylné k podpoře radikálních islamistických skupin. Zdůrazněme, že nepřiměřené násilí vládních jednotek vůči lokální populaci je považováno některými autory za hlavní faktor př́klonu postižených komunit ke skupinám jako Boko Haram v nigerijském konfliktu. ${ }^{14}$

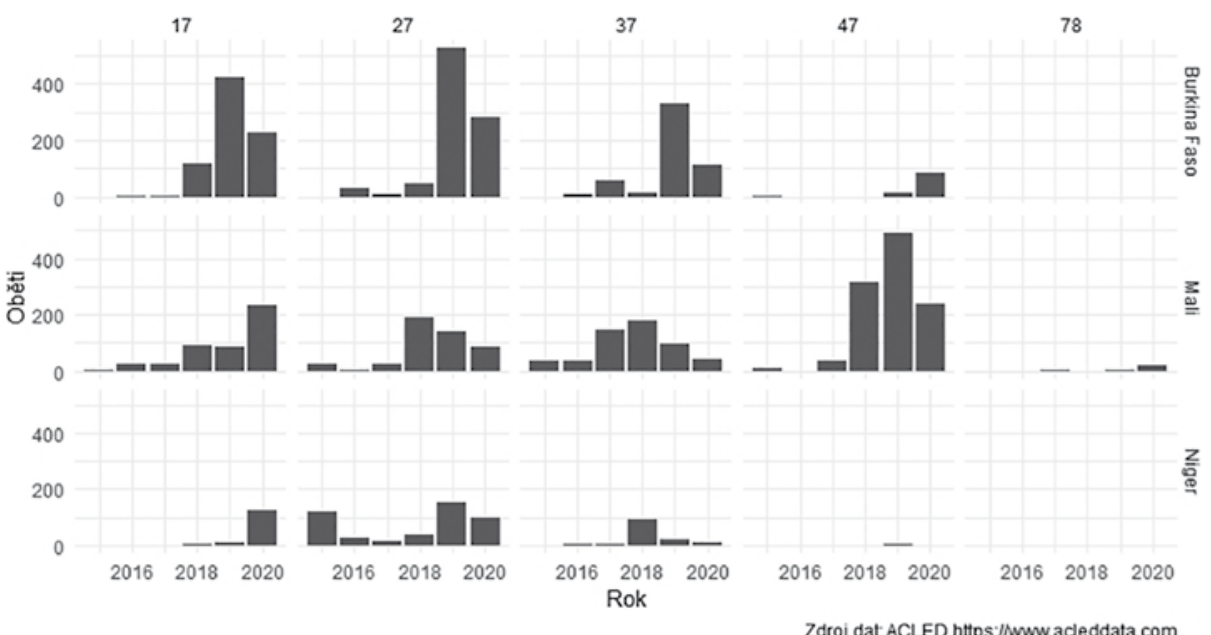

Graf č. 5: Typy aktérů v incidentech „násilí proti civilistům“

13 TOBIE, Aurélien (2017, s. 12)

14 HANSEN, William. The ugly face of the state: Nigerian security forces, human rights and the search for Boko Haram. Canadian Journal of African Studies / Revue canadienne des études africaines [online]. , 1-19 [cit. 2020-08-01]. DOI: 10.1080/00083968.2019.1700813. ISSN 0008-3968. Dostupné z: https://www. tandfonline.com/doi/full/10.1080/00083968.2019.1700813 
Výrazný je též trend útoků na civilisty ze strany lokálních milic - zde se jedná zejména o útoky mezi (pasteveckými) Fulby a (zemědělskými) Dogony ${ }^{15}$. Dramatický nárůst těchto masakrů ukazuje na neschopnost centrální vlády zajistit zákon a pořádek v rurálních oblastech. Zároveň jej Ize číst jako varování před přilišným spoléháním na lokální milice jako náhrady za vládní síly. Data potvrzují varování, že lokální milice sice mohou působit proti protivládním silám, ale velmi rychle se mohou přeorientovat na terorizování okolních komunit a tím paradoxně přispívat $\mathrm{k}$ zhoršování bezpečnostní situace. ${ }^{16}$ Zároveň nečinnost vlády (či přímo schovívavost) vưči např. Dogonským milicím může vést Fulby k př́klonu $\mathrm{k}$ islamistickým skupinám nabízejícím ohroženým skupinám ochranu a príležitost $k$ pomstě ${ }^{17} Z$ opačné strany ale musíme vidět, že tam, kde vláda nedokáže účinně působit proti islamistům a jejich místním spojencům, bude vznik lokálních milic naprosto logickou reakcí ohrožených (nejen dogonských) komunit. V souhrnu, dynamika násilí proti civilistům je jedním z aspektů konfliktu, jehož podcenění může výrazně ohrozit stabilizaci bezpečnostní situace.

\subsection{Krátkodobý vývoj vybraného regionu Mopti}

Z výše uvedeného přehledu vystupuje region Mopti jako region s mimořádným počtem obětí současného konfliktu. Níže se proto zaměříme na analýzu násilných událostí v tomto regionu za prvních šest měsíců roku 2020. Krom analýzy geografické distribuce násilných událostí se zaměříme i na to, kteří aktéři interagují jako hlavní protivníci. Region Mopti má rozlohu zhruba 79000 km², přičemž počet jeho obyvatel byl před deseti lety pouze 2 miliony osob (odhadujeme, že nyní půjde o 2,5 - 3 miliony). Byt́ se malijská armáda rozrůstá - na konci r. 2019 odhadována na 13000 osob s ekvivalentem 8 - 9 bojových praporů ${ }^{18}$, v současnosti (dle informací recenzenta) jde již o 15000 osob pozemních sil a 2-3 000 osob letectva a ekvivalent 18 bojových praporů - stále jde vzhledem k rozloze teritoria o poměrně malou sílu. V Mopti tak dlouhodobě působí jen 2 prapory a byt' je doplňuje národní garda a gendarmerie, nepřekvapí, že velká část území se pod přímou vládní kontrolou nachází v nejlepším nárazově.

\subsubsection{Geografická distribuce}

Pohled na schematickou mapu bojů, explozí, a násilí proti civilistům ukazuje výrazný překryv mezi boji a explozemi a násilím proti civilistům. Podobně jako na makro-úrovni

15 YAHAYA, Ibrahim a Mollie ZAPATA. Regions at Risk: Preventing Mass Atrocities in Mali. Washington: United States Holocaust Memorial Museum, April 2018. Dostupné z: https://www.ushmm.org/m/pdfs/ Mali_Report_English_FINAL_April_2018.pdf

16 Tamtéž

17 Tamtéž

18 Chapter Nine: Sub-Saharan Africa. The Military Balance [online]. 2020, 120(1), 444-514 [cit. 2020-08-01]. DOI: 10.1080/04597222.2020.1707971. ISSN 0459-7222. Dostupné z: https://www.tandfonline.com/ doi/full/10.1080/04597222.2020.1707971 
platí, že incidentů typu exploze a jejich obětí je výrazně méně, než v případě zbylých dvou typů incidentů. Je také zřejmé, že události se odehrávají zejména v „cercles“ (nižší administrativní jednotky) při hranicích s Burkinou Faso. Naopak dva nejzápadnější cercles (za řekou Niger) jsou konfliktem téměř nedotčeny. Jistou zvláštností je i patrný prázdný okruh kolem administrativního centra regionu - města Mopti (v mapě černý bod). Toto geografické rozdělení není překvapivé, uvážíme-li demografické i vojenské ohledy. Východní část regionu Mopti je oblastí, kde se střetávají pastevečtí Fulbové se zemědělskými Dogony. Jejich stále častější střety mají tendenci prolínat se s širší rovinou konfliktu mezi vládou a islamistickými povstalci.

Z vojenského hlediska Ize vyslovit předpoklad, že pro povstalce (ale i lokální milice) je mnohem snazší působit dále od hlavních regionálních center (město Mopti), která jsou pod kontrolou vládních sil. Vzhledem k výše zmíněným početním omezením malijské armády mohou povstalci počítat s tím, že pokud zaútočí na vládní síly dále jak 50 km od nejbližší větší vojenské základny, budou mít pravděpodobně několik hodin, než na místo dorazí armádní posily. Výjimku představuje využití leteckých prostředkủ. Těch má však Mali jen minimum ${ }^{19}$ a i u nich platí, že enormní vzdálenosti v Mali výrazně redukují pohotovost jejich zásahu. Hraniční oblasti také vytvářejí (přinejmenším z legálních důvodů) pro vládní síly řadu omezení pro manévr silami a palbou, což nabízí povstaleckým silám možnost uniknout na druhou stranu hranice a tím se zachránit. Zároveň koordinace sil ozbrojených sil různých států vytváří řadu problémů, které dále zvyšují relativní výhodu povstalců. Působení mezinárodních (takticky a technologicky výrazně vyspělejších) sil komplikuje působení povstaleckých skupin, výše řečené přesto zůstává na obecné rovině v platnosti.

Abychom ověřili výše zmíněný předpoklad, spočetli jsme (leteckou) vzdálenost v regionu proběhnuvších incidentů od města Mopti a zanesli do grafu 6, který filtruje pouze střety mezi vládními silami (vč. mezinárodních sil) a islamistickými skupinami, a to pro události typu boje a exploze. Ukazuje se, že JNIM napadá vládní síly jen výjimečně ve vzdálenosti menší jak 100 km. A i naopak platí, že vládní síly napadají povstalce jen výjimečně v blízkosti města Mopti. Tento základní rys je shodný pro obě sledované kategorie. Poněkud odlišnou situaci vidíme jednak u francouzské armády a pak u Katiby Maciny (islamistické skupiny, která je součástí JNIM). V případě Katiby se jedná o čtyři útoky bez obětí. Vysvětlení je zde poměrně jednoduché, Katiba je demograficky ukotvena v centrální části regionu Mopti (jakož i v regionu Segou a Koulikouro), pročež je větší šance, že její aktivity budou blíže regionálními centru. V př́padě francouzské armády (která však působí v regionu pouze nárazově) pak jeden z incidentů nese nejnižší stupeň geolokační přesnosti. Jde tedy o případ, který byl geolokován k městu pouze formálně.

Graf také ukazuje jeden pro jakékoliv hlubší analýzy významný fakt. Jen menší část bitev a explozí má nejvyšší stupeň geolokační přesnosti. Většina má stupeň střední.

19 Po dubnovém pádu A29 zůstali Mali jen tři lehké bitevní stroje. BINNIE, Jeremy. Two Pilots Killed in Malian Super Tucano Crash Landing. In: Janes Defense Weekly [online]. Apr 15, 2020. [cit. 2020-0801]. Dostupné z: https://emagazines.janes.com/webviewer/\#janesdefenceweekly15april2020/ two_pilots_killed_in_malian_super_tucano_crash_landing 
V těchto prípadech jsou události lokalizovány $\mathrm{k}$ nižším správním centrům. ${ }^{20}$ Pro analýzu na úrovni vyšších regionálních celků nejde o významný problém, zejména ne u analýz delších časových úseků. Kdybychom však chtěli analyzovat jen jeden či dva vybrané cercle(s), museli bychom již velmi důkladně zkoumat i geolokační přesnost jednotlivých záznamů a možné dopady na analýzu.

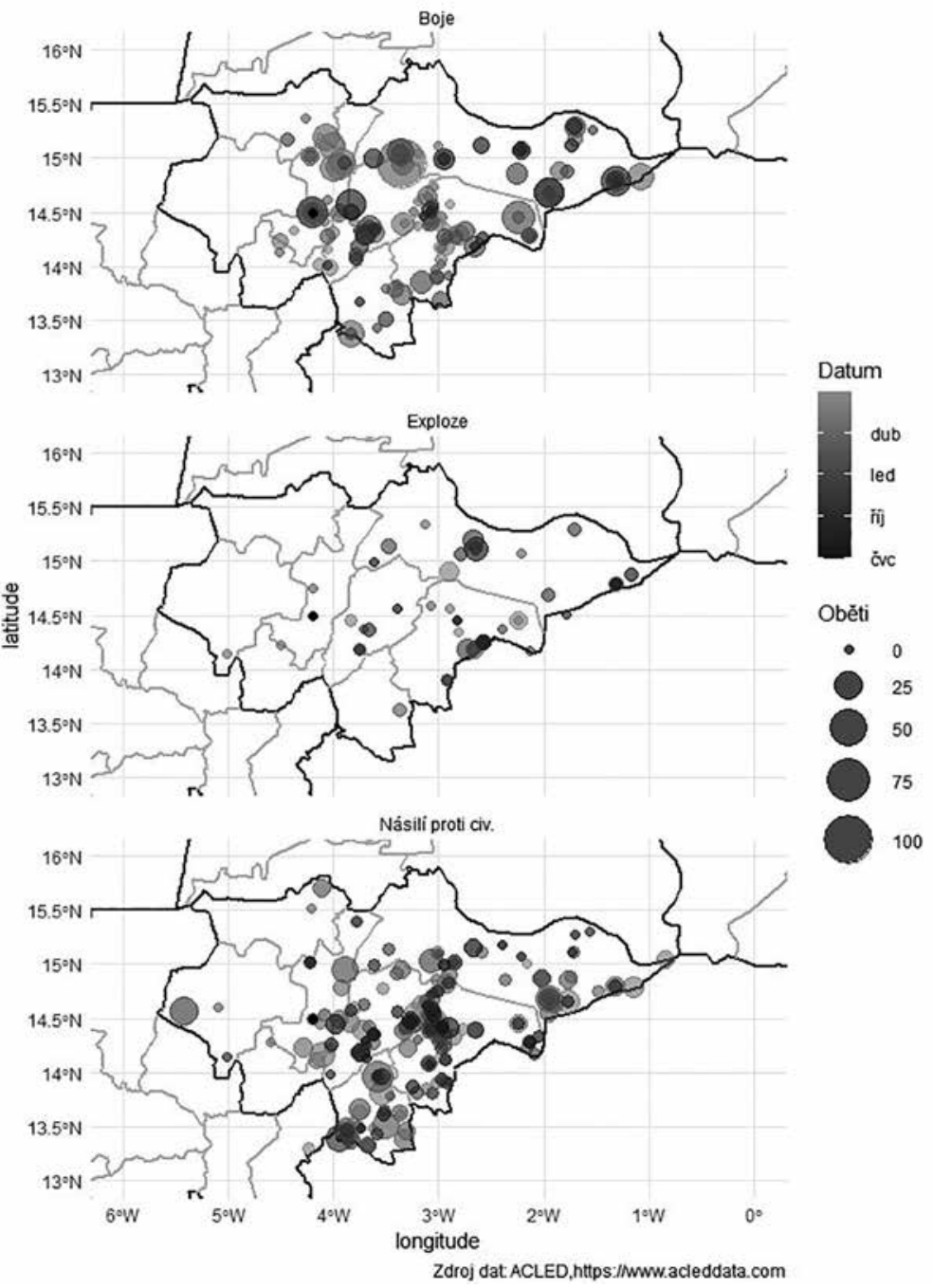

Mapa č.2: Geografická distribuce násilných událostí v regionu Mopti (1.7.2019-30.6.2020)

20 Pozorný čtenář si v mapě 2 také všiml události, která se odehrála v provincii Ségou (jižní soused Mopti), ač je mylně vedena pod regionem Mopti. 


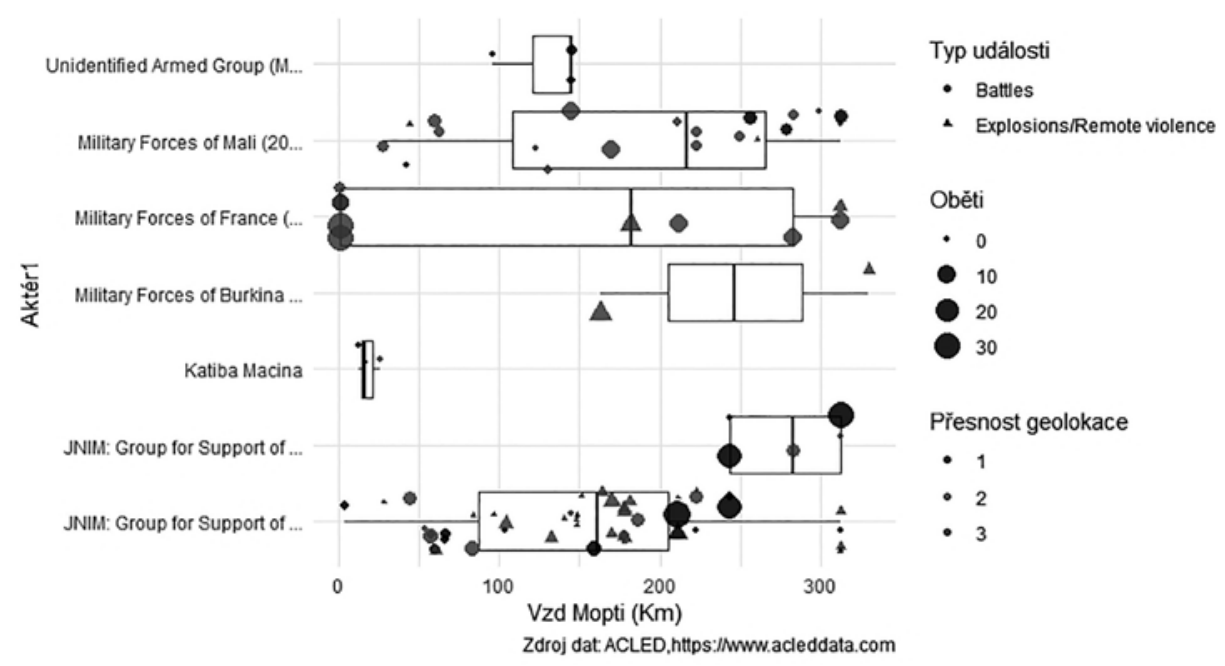

Graf č. 6: Vzdálenost bojů mezi vládou a islamisty od města Mopti

\subsubsection{Hlavní aktéři}

Zmínili jsme otázku komplexnosti konfliktu, kde se potkává větší množství aktérů. Někteří s širšími politickými zájmy (vláda, povstalci), jiní s regionálně i politicky omezenými zájmy (lokální milice). Pro pochopení konfliktu je dobré poznat základní osy nepřátelství či spolupráce mezi těmito aktéry.

Graf 7 porovnává počty střetů s alespoň jednou obětí mezi jednotlivými aktéry na území regionu Mopti v druhém půlroce 2019 a prvním půlroce 2020. Výrazný nárůst počtu nepřátelských interakcí se odehrál mezi na jedné straně fulbskými milicemi a na druhé straně dogonskými milicemi a převážně dogonskou skupinou Dan na Ambassagou - potvrzuje se tedy, že značná část konfliktu má lokální charakter. Jak jsme řekli výše, dogonské milice byly dlouho tolerovány a podporovány vládou, protože bojovaly proti islamistickým skupinám v oblasti. Naopak islamistické skupiny nacházely podporu zejména mezi Fulby. $V$ současné době dochází $k$ řadě drobných ale i velkých útoků fulbských milic na Dogony. $Z$ druhé strany pak došlo $k$ několika velkým útokům Dogonů na Fulby (menší útoky jsou zřídkavější).

$\checkmark$ posledních měsících však také došlo na střety mezi do té doby implicitně spolupracujícími islamistickými skupinami (JNIM a Islámský stát) což je aspekt, který jsme viděli i v agregátních datech pro celé zájmové území. A proto v graf 7 uvádí aktéry „JNIM“ a „JNIM/Islámský stát" a „Islámský stát". Tyto vnitro-islamistické boje po sobě zanechaly 
desítky mrtvých, což ukazuje na hloubku rozkolu. ${ }^{21}$ Zda bude tento rozkol mezi islamistickými skupinami pokračovat je otázkou, logicky však oslabuje povstalce a dává přiležitost malijské armádě.

Druhou hlavní skupinu střetů tvoří boje mezi vládními silami (počítaje v to i mezinárodní síly) a islamisty (tj. zejména Islámským státem a JNIM). Zde je také vidět, že ofenzivní akce proti islamistům jsou primárně věcí armády. Policie a gendermarie (četnictvo) se také stávají účastníky střetů, v jejich př́padě však častěji jde o situace, kdy islamistické skupiny napadnou jejich odloučené stanice.

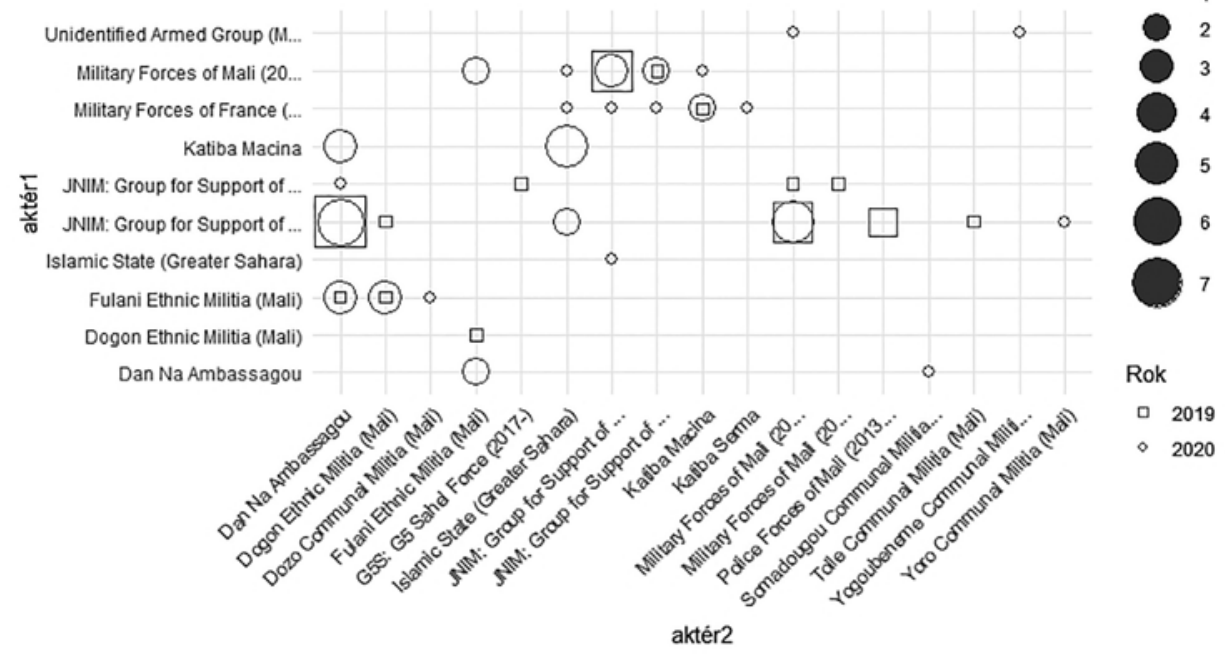

Graf č. 7: Porovnání počtu neprátelských interakcí v 2. pololetí 2019 a 1. pololetí 2020

Ač má konflikt svou lokální úroveň, boje mezi vládou a islamistickými skupinami (právě díky jejich širšímu záběru a schopnosti využívat lokálních třenic) zůstávají klíčovým bezpečnostním problémem Mali. Musíme se proto ptát, jak si vede Malijská armáda, střetne-li se s islamistickými skupinami.

\section{BOJOVÁ EFEKTIVITA MALIJSKÉ ARMÁDY}

Databázi ACLED Ize v omezené miře využít i pro analýzu průběhu významnějších střetnutí. Ke každé události totiž databáze nabízí stručné shrnutí průběhu střetnutí. Větší stř̌etnutí se navíc obvykle stanou předmětem širší pozornosti médií, pročež jsou

21 FOREIGN MILITARY STUDIES OFFICE. Al-Qaeda Loyalists Defect to ISIS in the Sahel. OE WATCH: Foreign News \& Perspectives of the Operational Environment [online]. 2020, roč. 10, č.3 [cit. 2020-08-01]. Dostupné z: https://community.apan.org/wg/tradoc-g2/fmso/. 
dostupné informace podrobnější a přesnější. Vyfiltrovali jsme tedy střety od počátku roku 2019 mezi malijskou armádou a povstalci (viz príloha C) s počtem obětí dvacet a vyšší.

Podle údajů ACLEDu si těchto jedenáct střetů vyžádalo 365 obětí. Ztráty malijské armády a gendermerie činily celkem 264 mrtvých (k tomu desítky raněných a pohřešovaných). Na straně militantů padlo minimálně 126 osob., pravděpodobně však více (útočníci většinou mohli své mrtvé a raněné $z$ bojiště odnést).

Přitom jen $v$ jednom prípadě šlo o útok na konvoj v terénu, v ostatních prípadech se jednalo o útok na základnu. Ve třech případech Ize na základě počtu zabitých, zraněných a pohřešovaných vojáků odhadnout, že na základnách se nacházela jednotka o síle roty, v ostatních přinejmenším posílené čety. Základny s posádkou kolem 100 osob by neměly být lehkým cílem, přesto se $v$ devíti případech podařilo povstalcům vojáky ze základen po krátkém boji vypudit a zničit či ukořistit techniku a zbraně. Ani v jednom z těchto př́padů nebyla malijská armáda sto přesunout posily do oblasti dříve, než se povstalci ze základen stáhli. Pouze ve dvou případech se podařilo využít letecké podpory, v jednom př́padě však až na stahující se povstalce s ukořistěnou technikou.

Na straně povstalců je $v$ některých prípadech vidět jistá sofistikovanost. $V$ prípadě útoku na konvoj u Dagabory (14.6.2020) zkombinovali bojovníci Katiby Maciny IED s následnou kulometnou palbou. V př́padě útoku na základnu v Tarkintu (19.3.2019) zahájili přepad minometnou palbou, během níž se přibližili k základně. Tyto akce představují spíše vzácný vrchol taktického umu povstaleckých skupin, přesto ukazují na to, že taktické schopnosti povstalců mohou překonávat taktické schopnosti řady jednotek malijské armády. Tento krátký exkurz nepřímo ukazuje, že byt́ v Mali pưsobí řadu let výcvikové mise, zlepšení taktických kompetencí je omezené (což potvrzuje závěry čerstvé studie D. Tulla22). Extrémní rozloha území Mali znamená, že posily na řadu míst nedorazí dřive než během několika hodin. Mimořádné vzdálenosti a omezený počet letecké techniky (jakož i minimum kvalifikovaných leteckých návodčí) omezuje využitelnost letecké podpory. Právě v těchto podmínkách je základní taktický a střelecký výcvik alfou a omegou pro zlepšení vyhlídek armády.

O lokální situaci dobře informovaný recenzent upozornil, že ve výše popisovaných př́padech se útočníkům vždy podařilo přečílit a překvapit obránce nacházející se $v$ jen omezeně zodolněných shlucích budov. Domníváme se, že tento cenný postřeh spíše podtrhává některé specifické problémy malijské armády, než že by zneplatňoval náš hlavní argument. V každém př́padě zde již narážíme na limity databáze ACLED, která pro potřeby analýzy např. bojové efektivity nabízí spíše jen doplňkový nástroj.

22 TULL, Denis M. Rebuilding Mali's army: the dissonant relationship between Mali and its international partners. International Affairs [online]. 2019, 95(2), 405-422 [cit. 2020-08-01]. DOI: 10.1093/ia/iiz003. ISSN 0020-5850. 


\section{ZÁVĚR}

Naše analýza se snažila ukázat na možnosti využití databází konfliktů. Tyto databáze nabízejí dvojí využití. Jednak slouží k (zejména akademické) analýze příčin, průběhu a výsledků konfliktů. Jsou-li dostatečně často aktualizovány, umožňují navíc i praktičtější analýzu aktuálních trendů konfliktu, změn interakcí hlavních aktérů apod. Tyto informace (samožrejmě v kombinaci s dalšími zdroji) mohou být velmi cenné v situacích, kdy AČR (at' již v jakékoliv roli) působí v konfliktních oblastech.

Klíčovou výhodou ACLEDu oproti podobným databázím je její průběžná aktualizace. Je-li v čistě akademické praxi např. roční periodicita aktualizace přijatelná, pro praktickou situační analýzu to neplatí. Uvážíme-li, že standardní rotace útvarů AČR v zahraničních misích činí půl roku, smysluplný reporting o vývoji bezpečnostního prostředí by se měl opírat o data aktualizovaná čtvrtletně, či měsíčně.

Ani ACLED, stejně jako ostatní databáze, není zcela kompletní a přesný. Porovnání dat různých databází, případně ověření v dalších relevantních zdrojích, nabízí cestu k alespoň částečnému zpřesnění informací. Speciálně je třeba zvažovat dva systémové zdroje nepřesností. Za prvé, v případě Mali je cca 20 \% incidentů v druhé a třetí kategorii přesnosti geolokace. Tyto události jsou geolokovány $\mathrm{k}$ regionálnímu, či subregionálními centru. Přesnost geolokace, aniž by to uživatel mohl zaregistrovat, však může ovlivnit i mylný přepis názvu místa/obce při prvotním reportingu, nebo při přepisu do databáze. Druhou systematickou chybou je udávaný počet obětí. Ten je často nadnesený a u menších incidentů jen obtížně ověřitelný. Do hry však může vstoupit i zaujatý reporting médií, či jiných organizací, na kterém stojí databáze ACLED. Tyto nepřesnosti mají spíše omezený dopad na makroregionální analýzy hlavních trendů. Mohou však zásadně ovlivnit výsledky podrobnějších analýz úzce vydefinovaných geografických oblastí. Zdůrazněme, že databáze ACLED (aj.) sama o sobě nabízí pouze jednu (nutně omezenou) vrstvu informací o konfliktu, pročež by její vytěžení mělo být vždy integrováno s lokální/regionální expertízou. Obecně Ize tvrdit, že čím tematicky specifičtější a geograficky podrobnější analytický záměr, tím slabší bude samostatný přínos konfliktních databází.

Hlavní věcná zjištění analýzy Ize shrnout do dvou bodů: (i) růst násilných událostí je masivní a má zjevně přeshraniční charakter. Bez vnější podpory reálně hrozí, že se Mali jako stát rozpadne a jeho části ovládnou bud' lokální milice či islamističtí povstalci, (ii) výrazný díl násilností se odehrává na lokální úrovni mezi různými etniky, přičemž tyto střety často cílí přímo na civilisty. Slabost malijské armády vytváří příznivé prostředí pro tento typ násilí, které však logicky jen dále umenšuje (již tak omezenou) důvěru v centrální vládu.

Na vojenské rovině Ize zdůraznit dva související aspekty - extrémní rozlohu území a omezené schopnosti malijské armády. Extrémní rozloha především ředí hustotu nepočetných sil armády. Velké kusy území tak jsou po většinu času mimo kontrolu, což povstaleckým skupinám (ale i lokálním milicím) výrazně zjednodušuje působení. Omezený počet letadel, vrtulníků a dronů dále snižuje schopnost kontrolovat větší prostory a př́padně vypomoci napadeným jednotkám.

Bohužel malijská armáda vykazuje řadu základních nedostatků. Střelecké schopnosti jsou hodnoceny jako minimální, výcvik dělostřelců několik let vůbec neprobíhal, 
v důsledku omezeného vzdělání a gramotnosti je využití sofistikovanější techniky problematické. $V$ těchto podmínkách těžko může např. malijské letectvo (i kdyby bylo početnější), nebo dělostřelectvo (i kdyby bylo vybaveno houfnicemi s větším dostrelem) ovlivnit průběh většiny střetnutí. Nepřekvapí tak, že jsou islamistické skupiny schopny úspěšně napadat konvoje a menší vojenské základny o síle i menších rot.

Autoři: $\quad$ RNDr. Jan Kofroň, Ph.D., narozen v roce 1984. Je absolventem Př́rodovědecké fakulty Univerzity Karlovy v Praze (2008), kde získal i doktorský titul (2012) v oboru politická a regionální geografie. $V$ současné době pracuje jako odborný asistent a zástupce vedoucího katedry politologie na fakultě sociálních věd UK. Jeho výzkum a výuka se zaměruje na geopolitiku, metodologii a oblast vojenství.

Ing. Michal Opletal, Ph.D., narozen 1986. Absolvent VŠCHT, kde získal v roce 2018 doktorát $v$ oboru Chemické a Procesní inženýrství. $V$ prüběhu postgraduálního studia se aktivně zajímal o problematiku analýzy dat, strojového učení a dálkový satelitní průzkum. Tento zájem ho roku 2018 přivedl do firmy Gisat, kde v současné době pracuje na pozici vedoucího softwarového vývoje.

Mgr. Matyáš Zrno, narozen 1979. Je absolventem Fakulty sociálních věd Univerzity Karlovy v Praze (2005) v oboru německá a rakouská studia. Pưsobil jako vedoucí civilní části Provinčního rekonstrukčního týmu v afghánské provincii Logar v letech 2010-2011. Dlouhodobě komentuje dění v zemích bývalé Jugoslávie a zabývá se protipovstaleckým bojem. Je programovým ředitelem Občanského institutu, šéfredaktorem Psychologie dnes a Konzervativních novin. Přednáší na Masarykově univerzitě a na CEVRO Institutu.

Jak citovat: KOFROŇ, Jan, Michal OPLETAL a Matyáš ZRNO. Analýza dynamiky konfliktu v Mali - využití databáze ACLED. Vojenské rozhledy. 2020, 29 (4), 046-064. ISSN 1210-3292 (print), 2336-2995 (on-line). Available at: www.vojenskerozhledy.cz. 


\section{Stanovování a hodnocení kompetencí důstojníka ozbrojených sil České republiky}

\section{Defining and Evaluation of Competencies of an Officer of the Czech Armed Forces}

\section{Jaroslav Kuba, Richard Saibert}

Abstrakt: Článek se zabývá problematikou stanovování a hodnocení kompetencí vyšších důstojníků ozbrojených sil České republiky. Př́spěvek zkoumá roli služebních orgánů odpovědných za správu vojenských oborů a odborností v systému definování kompetencí důstojníků a možnosti uplatnění kompetenčního modelu vojáka z povolání definovaného v Národní soustavě povolání v rámci řízení kariér vojáků. Jako komplexní a optimální řešení je navržena plná aplikace tohoto modelu využívající všechny složky kompetencí. Částečná, tedy parciální aplikace modelu kompetencí je založena pouze na využití složky měkkých kompetencí. Oba tyto návrhy jsou formulovány především pro potřeby popisu služebního místa a služebního hodnocení vojáka. Příspěvek přináší rovněž radu návrhů v koncepční a normotvorné oblasti.

Abstract: The article deals with the issue of identification and evaluation of the competencies of senior officers of the Czech Armed Forces. Paper investigates the role of the authorities responsible for military branches and military occupation specialties in the system of defining officer's competencies. It was also examined the scope of possible application of the competency model of a professional soldier defined by the National System of Occupations in the process of career management. As a comprehensive and optimal solution, a full application of competency model is proposed. The partial application of the competency model is based only on the use of the soft competencies component. Both of these proposals are formulated primarily for the purpose of describing the job position and official evaluation. The paper also brings a number of proposals in the conceptual and normative area.

Klíčová slova: Kompetence; kompetenční model; kvalifikační požadavky; měkké kompetence; služební hodnocení; vojenská odbornost.

Keywords: Competency; Competency Model; Qualification Requirements; Soft Competency; Official Evaluation; Military Occupation Specialty. 


\section{ÚVOD}

Ozbrojené síly (OS) představují jeden ze základních nástrojů státní moci České republiky (ČR) a jsou hlavním výkonným prvkem systému obrany státu. Rozhodující složku OS představuje Armáda České republiky (AČR). OS ČR se stále vyvíjejí a je nezbytné, aby reagovaly na aktuální dění v oblasti obrany a bezpečnosti, a to nejen s ohledem na ČR jako takovou, ale i s ohledem na její zapojení do mezinárodních organizací. OS musí být prioritně tvořeny personálem, který je na vysoké profesionální úrovni, má požadované znalosti, osvojeny stanovené dovednosti a návyky, přičemž musí být zároveň ztotožněn $s$ tradičními vojenskými hodnotami, jako je odpovědnost, smysl pro povinnost, obětavost, odvaha, věrnost, čest a hrdost k tradicím OS ČR, obrana demokratických hodnot, ochrana lidských práv a zajištování bezpečnosti státu. Aby bylo tohoto stavu dosaženo, je nezbytné přesně stanovit požadavky a kritéria na personál a zabezpečit jeho kvalitní výchovu, vzdělávání a výcvik ${ }^{\mathbf{1}}$.

Příspěvek, který navazuje a dále rozvíji článek publikovaný ve Vojenských rozhledech č. 1/2019, se zabývá současnou situací v oblasti definování požadavků na schopnosti a dovednosti (kompetence) vyšších důstojníků OS ČR, zejména z perspektivy služebních orgánů odpovědných za správu vojenských oborů a odborností a jejich rolí v systému definování požadavků na tyto kompetence. Zkoumána byla také možnost, v jaké míre lze aplikovat kompetenční model zakotvený v Národní soustavě povolání (NSP) do systému rízení kariér vojáků z povolání.

Hlavní ambicí příspěvku je představit soubor návrhů a doporučení k zavedení systémového přístupu ke stanovování a hodnocení kompetencí vyšších důstojníků OS ČR, včetně možného způsobu implementace souborů kompetenčních požadavků do podmínek rezortu MO. Výsledná doporučení jsou založena na modelu, jehož jádrem je popis služebního místa vojáka z povolání.

Výzkum je založen především na výsledcích šetření formou strukturovaných rozhovorů u služebních orgánů odpovědných za správu vojenských oborů a odborností, a dále obsahových analýzách jak strategických a koncepčních dokumentů, tak dalších vnitřních předpisů a normativních aktů vztahujících se k problematice definování požadavků na kompetence vojenského personálu.

\section{TERMINOLOGIE}

Kompetence pro potřeby toto článku bude chápána jako schopnost, dovednost či způsobilost úspěšně vykonávat a řešit určité úkoly v pracovních, popřípadě jiných životních situacích ${ }^{2}$.

1 Koncepce prípravy personálu pro potreby rezortu Ministerstva obrany, MO: Praha, 2019.

2 PRŮCHA, Jan, WALTEROVÁ, Eliš̌ka, MAREŠ, Jiří. Pedagogický slovník. 7., aktualiz. a rozš. vyd. Praha: Portál, 2013. 395 s. ISBN 9788026204039. 
Stejně jako se vyskytuje mnoho definic pojmu kompetence, tak je různorodé i samotné členění kompetencí. Základním je rozdělení na klíčové kompetence, které slouží $k$ popisu projevu chování a jsou pro všechny zaměstnance důležité, přispívají k firemním hodnotám, firemní kultuře a k očekávanému výkonu³ ${ }^{3}$ Generické kompetence jsou univerzální, nezávislé na konkrétní pozici zastávané jedincem nebo na konkrétní organizaci a Ize je tedy uplatnit kdekoliv.

Strukturu kompetence lze vyjádřit různými modely. Na vrcholu hierarchického modelu kompetence (obrázek 1 ) je vědomé chování, které jde nejsnáze ovlivnit či naučit. $\mathrm{Na}$ další úrovni jsou osobnostní složky jedince, které jsou nutné $k$ dosažení požadovaného výkonu na pracovní pozici, a které Ize do určitého stupně rozvíjet především výcvikem a koučováním. Stabilní charakteristiky osobnosti, které Ize ovlivňovat a rozvíjet komplikovaně za pomoci silné vůle a odhodlání náleží do nejnižšího stupně modelu struktury kompetence ${ }^{4}$.

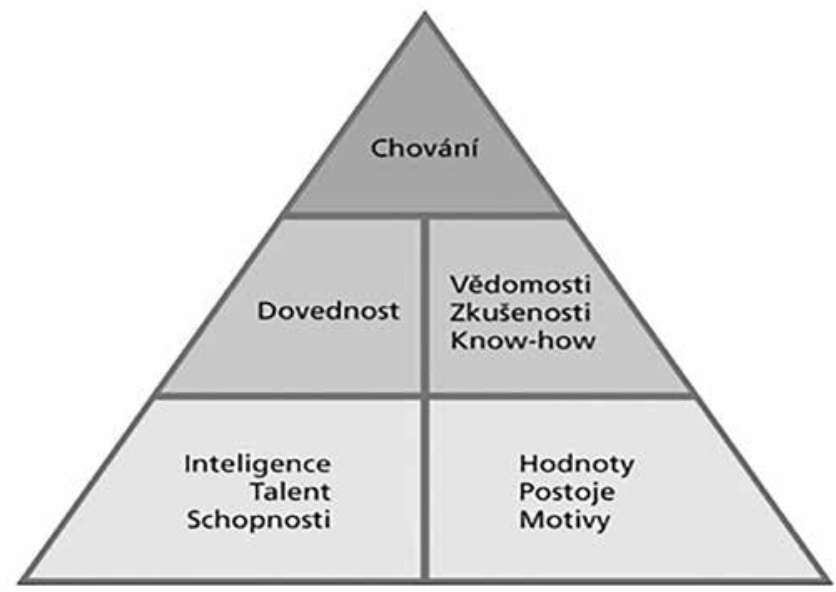

Obrázek č. 1: Hierarchický model struktury kompetence

Zdroj: KUBEŠ, Marián, Roman KURNICKÝ a Dagmar SPILLEROVÁ, 2004. Manažerské kompetence: způsobilosti výjimečných manažerů. Praha: Grada. Manažer. ISBN 80-247-0698-9.

Řízení lidských zdrojů podle kompetencí je systém řízení lidských zdrojů (obrázek 2), který slučuje jednotlivé personální procesy do komplexního systému, ve kterém jsou jednotlivé funkce řízení lidských zdrojů integrovány soustavou požadovaných způsobilostí, resp. modelem profesní kompetence. Řízení podle kompetencí je progresivní přístup $\mathrm{k}$ řízení firem, který je založený na vzájemné synergii „tvrdých“ faktorů řízení (struktura a

3 KUBEŠ, Marián, Roman KURNICKÝ a Dagmar SPILLEROVÁ, 2004. Manažerské kompetence: způsobilosti výjimečných manažerů. Praha: Grada. Manažer. ISBN 80-247-0698-9.

4 Ref 3. 
strategie) a aspektů „měkkých“ (kompetence pracovníků). Cílem řízení lidských zdrojů dle Armstronga ${ }^{5}$ je zajistit, aby byla organizace schopna prostřednictvím lidí úspěšně plnit své cíle. $V$ prípadě, že je tento přístup vhodně implementován v rámci systému řizení lidských zdrojů, může být pro danou organizaci a její lidské zdroje velmi prínosný.

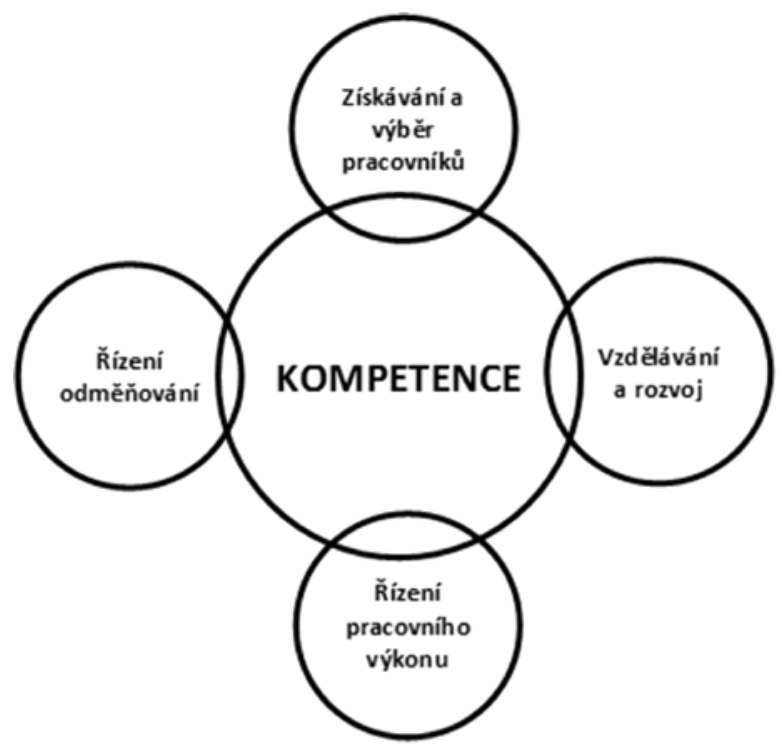

Obrázek č. 2: Základní prvky systému řízení podle kompetencí

Zdroj: ARMSTRONG, Michael. Armstong's Handbook of Human Resource Management Practice: 12th ed. Philadelphia: Kogan Page, 2012. 792 s. ISBN 9780749465506

Vojenská odbornost je souhrn znalostí, praktických dovedností a způsobilostí požadovaných pro výkon určité vojenské činnosti stejného typu a charakteru. Číslo vojenského oboru nebo odbornosti se určuje dvoumístným číslem podle číselníku vojenských oborů a odborností spolu s přehledem služebních orgánů odpovědných za správu jednotlivých vojenských oborů a odborností.

Vojenský obor je souhrn vojenských odborností, které vykazují společné nebo obdobné znaky anebo charakteristiky.

5 ARMSTRONG, Michael. Řízení lidských zdrojů: nejnovější trendy a postupy: 10. vydání. 1. vyd. Praha: Grada, 2007. 789 s. ISBN 9788024714073.

6 RMO č. 2/2019 Zásady tvorby systemizovaných míst. Praha: Věstník MO, 2019. 


\section{TEORETICKÁ VÝCHODISKA}

Základní koncepční východisko z pohledu zkoumaného př́stupu rezortu MO k problematice kompetencí vojenského personálu představuje systém a způsoby stanovování požadavků na schopnosti a dovednosti vojáků orgány odpovědnými za rozvoj vojenských schopností. Ve zkoumaném případě se jedná o služební orgány odpovědné za správu vojenských oborů a odborností (dále jen odpovědný orgán)7, které mají zásadní roli v metodickém řízení prípravy vojáků a stanovení zásad jejich odborné přípravy. Cílem je poskytnout vojenskému personálu nezbytné znalosti a dovednosti k výkonu odborných činností. Odpovědný orgán má svou nezastupitelnou roli při výběru vojáků z povolání do vzdělávacích a výcvikových aktivit ke splnění kvalifikačních předpokladů a kvalifikačních požadavků.

Důležitým prvkem vstupujícím do tohoto systému je řízení kariér vojáků z povolání, které je nastaveno s cílem trvale stabilizovat, udržovat, rozvíjet a motivovat vojáky v př́pravě a kariérovém růstu prostřednictvím jednotného postupu. Nezbytným předpokladem funkčnosti tohoto systému je splnění vymezených kritérii ${ }^{8}$, mezi která patří dosažená kvalifikace, služební hodnocení a služební praxe. Výsledkem je stanovené pořadí na postup do vyšší hodnosti. Hodnotí se tedy vojákovi kariérní předpoklady a hodnocení vojáků jedné vojenské hodnosti se provádí stejným způsobem např́č OS ČR.

$\checkmark$ rámci Agentury personalistiky (AP) AČR působí skupina podpory správy vojenských oborů a odborností za účelem využití informací v Informačním systému o službě a personálu (ISSP) pro ř́zení kariér vojáků. Tento prvek má za úkol mimo jiné poskytovat informace o stanovených odborných požadavcích na služebních místech a o jejich splnění, vydávat pokyny pro aktualizaci dat týkajících se návrhů nominací do příslušných vzdělávacích aktivit ke splnění stanovených odborných požadavkủ či podílet se na rozvoji ISSP $k$ zabezpečení podpory správy vojenských oborů a odborností.

$\checkmark$ rámci výše identifikovaného východiska, kterým je role odpovědného orgánu v systému definování požadavků na kompetence vyššího důstojníka, bude ověřována možnost aplikace stávajícího kompetenčního modelu v NSP pro účely jeho ukotvení v systému hodnocení vojáka. Jedním ze základních kritérí je relevance zvolených kompetencí vyšších důstojníků OS ČR, jejichž hodnocení poskytuje určité měřítko při posuzování možnosti jejich kariérního postupu.

S ohledem na hlavní poslání OS ČR, kterým je zabezpečení obrany a bezpečnosti státu, musí být konkrétní požadavky na schopnosti a dovednosti vyšších důstojníků definovány především na základě požadavků možných budoucích vojenských konfliktů či operací plynoucích z rychle se měnícího bezpečnostního prostředí, které je ovlivněno současnými válkami a konflikty, nejistotou a vzájemnou provázaností charakterizující bezpečnostní

7 Ref. 6.

8 Přiloha 1 k RMO č. 9/2017 Stanovení pořadí vojáků z povolání pro realizaci personálních opatření systému řizení kariér. Praha: Věstník MO, 2017. 
hrozby9 . Na neustále měnící se vývoj bezpečnostního prostředí reaguji i koncepční dokumenty OS ČR, z nichž Ize konkrétně zmínit např. Koncepci výstavby Armády České republiky 2030. V souladu s touto koncepcí by měl být v oblasti lidských zdrojů hlavní snahou pečlivý výběr konkurenceschopného personálu s adekvátními kompetencemi. Ekonomická motivace je rozhodně důležitá, ale důvody pro vstup do OS ČR jako jsou prestiž, hrdost, jistoty a perspektiva, by měly být prioritou.

Požadavky na vyšší důstojníky transformované do konkrétních kompetencí budou mít zásadní dopady na přípravu vojenského personálu zahrnující individuální a kolektivní formy přípravy, které je nutno vnímat jako systém, jehož princip byl popsán již v předchozí Koncepci prípravy personálu rezortu $\mathrm{MO}^{10}$. Tento systém představuje tzv. $\mathrm{P}=3 \mathrm{~V}$ (Př́prava = Výchova + Vzdělávání + Výcvik). U každé kategorie personálu jsou stanoveny předpoklady a požadavky, které vycházejí z potřeb rezortu $\mathrm{MO}$, jsou provázány se systémem řizení kariér a jejichž splnění je vyžadováno nebo doporučeno ${ }^{11}$. $S$ problematikou prípravy je úzce spojena otázka její obsahové náplně či uplatňovaných forem a způsobů výcviku a vzdělávání. Současná bezpečnostní situace a její možný vývoj vyžadují, aby se vojenská vzdělávací a výcviková zařízení v co nejširším rozsahu zabývala otázkami bezpečnosti státu a sehrávala $v$ této oblasti aktivní roli ${ }^{12}$.

$Z$ hlediska dalšího kariérního postupu vyšších důstojníků hraje jednu z určujících rolí rozvoj jejich klíčových (měkkých) kompetencí, které jsou zásadní pro splnění očekáváného výkonu, a které směřují do oblasti rízení (management) a vedení (leadership) lidí.

Horán (1999) v publikaci „Leadership“ vychází při určování kompetencí z výzkumu vlastního hodnocení manažerů. Jako kompetence důležité pro výkon manažerské funkce byly označeny: výkonnost; odpovědnost; cílevědomost; znalosti; rozhodnost; kreativita; schopnost kompromisu; vytrvalost; kooperace a komunikace ${ }^{13}$.

Ačkoliv se manažerské a leaderské kompetence mnohdy částečně překrývají, doplňují či na sebe vzájemně navazují, Ize přesto nalézt často zásadní rozdíly. Ty vychází jak z podstaty jejich uplatňování, tedy konkrétního pracovního zařazení (služební pozice), tak jsou zejména založeny na osobnosti každého jednotlivce, zejm. na jeho talentu, schopnostech, postojích apod.

Za zásadní kompetence leadera Ize považovat dle Arrudy (2016): vytváření vizí; schopnost inovace; podstupování rizika; dlouhodobé uvažování (myšlení); dlouhodobý a cílevědomý osobnostní rozvoj; budování vztahů; koučování lidí; budování následovnictví ${ }^{\mathbf{1 4}}$. Jedná se o schopnost a dovednost vést a ovlivňovat pracovníky tak, aby následovali vedení v zájmu stanovené vize $\mathrm{k}$ dosažení cílů. Oblast leadershipu figuruje mimo jiné $\mathrm{i}$

9 Bezpečnostní strategie České republiky. Ministerstvo zahraničních věcí České republiky, 2015. ISBN 978-80-7441-005-5.

10 Koncepce prípravy personálu rezortu MO pro období 2012 - 2018. MO: Praha, 2011

11 Ref. 10.

12 Ref. 10.

13 HORAN, J., Leadership, Orana; Jul99, Vol. 35 Issue 2, p19, 7p, ISSN 00456705.

14 ARRUDA, William. 9 Differences Between Being A Leader And A Manager. Forbes [online]. 2016 [cit. 2020-08-31]. Dostupné z:https://www.forbes.com/sites/ williamarruda/2016/11/15/9-differences-between-being-a-leader-and-a-manager/\#49c6a8474609 
v celoživotní príipravě vyšších důstojníků, především v rámci kariérové přípravy vyšších důstojníků a důstojníků generálního štábu. Pro všechny úrovně leadershipu je stanoven jako společný základ hodnotový rámec formující charakter velitele, resp. řídícího pracovníka. Zásadní rozdíly jsou v typu a úrovni požadovaných znalostí, dovedností a s nimi spojených vykonávaných činností. Naopak $\mathrm{k}$ ryze manažerským kompetencím Ize řadit: stanovování cílů; rrizení rizik; zdokonalování stávajících dovedností; budování systémů, procesů a organizačních struktur; řízení lidí15.

Obdobnou typologií se stanovenými indikátory, která je vhodná jako výchozí model pro další výzkum kompetencí vyšších důstojníků OS ČR, disponuje kompetenční model NSP, který uvádí následujících 15 měkkých kompetencí: efektivní komunikace; kooperace (spolupráce); kreativita; flexibilita; uspokojování zákaznických potřeb; výkonnost; samostatnost; řešení problému; plánování a organizace práce; celoživotní učení; aktivní přistup; zvládání zátěže; objevování a orientace v informacích; vedení lidí (leadership); ovlivňování ostatních ${ }^{16}$.

Výše uvedené kompetence definované kompetenčním modelem NSP, které v sobě zahrnují obě dimenze, tedy jak management, tak leadership, budou dále podrobeny dílčí analýze s cílem hledat jejich možnou aplikaci pro konkrétní služební místa v rámci OS ČR.

\section{METODOLOGIE}

Cílem výzkumu bylo na základě zhodnocení současné situace $v$ oblasti definování požadavků na kompetence vojenského personálu OS ČR a role odpovědných orgánů $v$ tomto procesu představit soubor návrhů a doporučení $k$ zavedení systémového přístupu založeného na implementaci kompetenčních požadavků do řízení kariér.

Výzkum se omezil na požadavky na kompetence vyšších důstojníků OS ČR, přičemž systémový přistup $k$ definování kompetencí byl zkoumán na aplikaci složky měkkých kompetencí definovaných $v$ kompetenčním modelu NSP. Byla zkoumána identifikace, aplikace, hodnocení a využití souborů kompetenčních požadavků na konkrétním služebním místě a jejich systémové propojení v rámci OS ČR. Při výběru výchozího kompetenčního modelu byla brána na zřetel zejména dostatečná relevance zvolených kompetencí pro vyšší důstojníky OS ČR, jejichž míra uplatňování v jejich profesním životě je měřítkem při posuzování možnosti kariérního postupu těchto vojáků.

$\mathrm{K}$ naplnění cíle výzkumu byla formulována výzkumná otázka: „Jakou roli mají služební orgány odpovědné za správu vojenských oborů a odborností v systému definování požadavků na kompetence vyšších důstojníků OS ČR?"

$\checkmark$ rámci komparativní a obsahové analýzy byla zkoumáno, zda se analyzované dokumenty věnují oblasti personálu, a zda zmiňují kompetence $v$ konkrétní, nebo alespoň $v$ obecné rovině. Rovněž byla hledána odpověd' na otázku, v jaké míře jsou v popisech

15 Ref. 14.

16 Národní soustava povolání [online]. Praha: Ministerstvo práce a sociálních věcí, 2017. Dostupné z: https:// nsp.cz/ 
služební činnosti vyšších důstojníků stanoveny měkké kompetence a zda jsou současně i součástí služebního hodnocení vojáka. Byla zároveň zkoumána i relevance měkkých kompetencí uvedených v NSP ve vztahu ke stanovování služebních schopností, dovedností a vlastností v rámci služebního hodnocení vojáka. Role odpovědných orgánů byla ověřována prostřednictvím strukturovaných rozhovorů s respondenty z řad služebních orgánů.

\section{ANALÝZA SOUČASNÉHO STAVU}

V rámci analýzy byl proveden rozbor současného stavu v oblasti definování požadavků na kompetence vyšších důstojníků OS ČR. Na základě výsledků komparativní a obsahové analýzy vybraných koncepčních dokumentů, včetně vnitřních předpisů rezortu MO Ize prohlásit, že rezort MO se zaměřuje získání a udržení připraveného, kvalifikovaného a motivovaného personálu. Dokumenty vymezují v hodnocených kritériích povinnosti služebním orgánům odpovědných za správu vojenských oborů a odborností, především v oblasti prípravy personálu. Dále Ize shledat, že zkoumané dokumenty se zabývají kompetencemi personálu velmi omezeně a $v$ obecnější rovině. Výsledky analýzy jsou uvedeny $v$ tabulce č. 1.

Tabulka č. 1: Komparativní analýza koncepčních dokumentů, včetně vnitřních předpisů

\begin{tabular}{|c|c|c|c|c|c|}
\hline \multirow[b]{2}{*}{ P. č. } & \multirow[b]{2}{*}{ Název dokumentu (předpisu) } & \multicolumn{4}{|c|}{ Hodnocená kritéria } \\
\hline & & $\begin{array}{l}\text { Vymezení pro- } \\
\text { storu otázce } \\
\text { vojenského } \\
\text { personálu }\end{array}$ & $\begin{array}{l}\text { Zmínění } \\
\text { kompetencí, } \\
\text { alespoň } \\
\text { v obecné } \\
\text { rovině }\end{array}$ & $\begin{array}{l}\text { Zmínění } \\
\text { konkrétních } \\
\text { kompetencí }\end{array}$ & $\begin{array}{l}\text { Vymezení } \\
\text { role služeb- } \\
\text { ních orgánů }\end{array}$ \\
\hline 1. & Obranná strategie České republiky & Ano & Ano & $\mathrm{Ne}$ & nehodnoceno \\
\hline 2. & Dlouhodobý výhled pro obranu 2035 & Ano & $\mathrm{Ne}$ & $\mathrm{Ne}$ & nehodnoceno \\
\hline 3. & $\begin{array}{l}\text { Koncepce výstavby Armá- } \\
\text { dy České republiky } 2030\end{array}$ & Ano & Ano & Ano & nehodnoceno \\
\hline 4. & $\begin{array}{l}\text { Koncepce př́ipravy personálu pro } \\
\text { potřeby rezortu MO } 2019\end{array}$ & nehodnoceno & Ano & Ano & nehodnoceno \\
\hline 5. & $\begin{array}{l}\text { RMO č. } 63 / 2015 \text { Některá ustanovení } \\
\text { o průběhu služby vojáků z povolání }\end{array}$ & nehodnoceno & $\mathrm{Ne}$ & $\mathrm{Ne}$ & Ano \\
\hline 6. & $\begin{array}{l}\text { RMO č. } 64 / 2015 \text { Působnost služeb- } \\
\text { ních orgánů v personální práci }\end{array}$ & nehodnoceno & $\mathrm{Ne}$ & $\mathrm{Ne}$ & Ano \\
\hline 7. & $\begin{array}{l}\text { RMO č. 9/2017 Stanoveni pořadí vojáků } \\
\text { z povoláni pro realizaci personálních } \\
\text { opatření systému ř́zení kariér }\end{array}$ & nehodnoceno & Ano & $\mathrm{Ne}$ & Ano \\
\hline 8. & $\begin{array}{l}\text { RMO č. } 2 / 2019 \text { Zásady tvor- } \\
\text { by systemizovaných mist }\end{array}$ & nehodnoceno & $\mathrm{Ne}$ & $\mathrm{Ne}$ & Ano \\
\hline 9. & $\begin{array}{l}\text { RMO č. } 57 / 2019 \text { Výběr vojáků z povolá- } \\
\text { ní do vzdělávacích a výcvikových aktivit }\end{array}$ & nehodnoceno & Ano & $\mathrm{Ne}$ & Ano \\
\hline
\end{tabular}


Výsledky zkoumání předpisů s vazbou na popis služební činnosti vojáka a vybraného vzorku reálných popisů služební činnosti vyšších důstojníků (konkrétně 86 popisů) ukázaly, že v rámci kritérií výběru personálu jsou zpravidla uváděny zkušenosti s velením a rízením osob, předchozí praxe, absolvování odborných kurzů a znalost práce v informačních systémech. $V$ rezortu MO jsou definovány pro dané služební místo kvalifikační předpoklady, tedy dosažení stanoveného stupně vzdělání a kvalifikační požadavky obsahující odborné znalosti a dovednosti. Tyto stanovené předpoklady a požadavky, které vycházejí z potřeb OS ČR, jsou provázány se systémem řízení kariér a jejich splnění je vyžadováno nebo doporučeno. V prímém srovnání se strukturou kompetenčního modelu NSP se jedná o kompetenční požadavky ve formě odborných znalostí a dovedností, která představuje jednu ze tří základních složek modelu kompetencí (obrázek 3).

Ze strukturovaných rozhovorů s respondenty z řad odpovědných orgánů Ize identifikovat několik následujících zjištění. Za výchozí zdroje pro stanovení kompetencí vyšších důstojníků Ize považovat dle respondentů následující:

- výstupy ze studia (manažerské vzdělání);

- aplikaci zkušeností z NSP;

- praxi konkrétních osob na dané pozici a jejich doporučení ve vztahu k požadovaným kompetencím na daném služebním místě;

- národní strategické a alianční dokumenty;

- zkušenosti ze zahraničních armád;

- popis služební činnosti vojáka;

- služební hodnocení vojáka;

- poznatky získané od personálních orgánů, psychologů, nadřizených a služebních orgánů odpovědných za správu vojenských oborů a odborností.

Jako konkrétní měkké kompetence, na které je potřeba se zaměřit, byly dotazovanými identifikovány: rozhodnost, odpovědnost, empatie, kreativita, mezilidské vztahy, řešení krizových situací, komunikace či sebevzdělávání. $K$ dalším kompetencím Ize dle nich radit zejména kompetence v oblasti rétoriky, respektování a ochrany národních tradic, kulturního a historického dědictví, odvahy reprezentovat svůj názor aj. V oblasti prípravy vojenského personálu by měl být položen důraz na oblasti vojensko-civilní spolupráce, znalosti státní správy či projektové řízení, ve kterých by měly být rozvíjeny kompetence vyšších důstojníků. Ze strany dotazovaných byl identifikován také nedostatek přiležitostí pro rozvoj kompetencí v oblasti pedagogiky či psychologie. Nezbytnou podmínkou pro výše uvedené je dle účastníků rozhovorů možnost kompetence hodnotit a požadovat jejich uplatňování tak, aby stanovené požadavky byly naplňovány personálem disponujícím reálnými schopnostmi.

Co se týče samotné role a postavení respondentů jako služebních orgánů v systému definování požadavků na kompetence vyšších důstojníků je možné ze získaných odpovědí indukovat následující závěry. Kompetence jako takové nejsou přesně definovány, je velmi obtižné definovat co je to kompetence. Tento pojem je velmi často spojován či zaměňován s kvalifikačními požadavky. Ve stávajících dokumentech neexistuje prostor pro vydefinování požadovaných kompetencí. Určitá skupina respondentů uvádí, že má možnost vyjadřovat se pouze ke kvalifikačním požadavkům a požadavkům na obecné kompetence (úroveň odborných znalostí a práce v informačních systémech). Zásadním limitem je omezený časový prostor, zejména u odborností, které spravují velký počet 
vojenského personálu. Kompetence jsou okrajově zmíněny ve služebním hodnocení vojáka spíše pro jeho karierový postup, ale nejsou stanoveny jako požadavek na zastávané služební místo $v$ popisu služební činnosti. Na vzdělávání vojenského personálu v rámci rezortu MO participuje pouze část respondentů, a to v podobě kariérových kurzů či formulaci témat absolventských prací a závěrečných prací kurzů vyšších důstojníků a kurzu generálního štábu (KVD a KGŠ). Na formulování učební dokumentace pro akreditované studijní programy nebo kariérové kurzy se nepodíli žádný z respondentů.

Závěrem je nezbytné zdůraznit, že získané odpovědi respondentů mohou být částečně zkreslené rozdílnou znalostí problematiky kompetencí.

\section{UPLATNĚNÍ KOMPETENČNÍHO MODELU V PODMÍNKÁCH OS ČR}

Z dosavadního šetření vyplývá, že za jediný doposud zpracovaný kompetenční model pro OS ČR Ize považovat soubor kompetenčních požadavků $k$ výkonu povolání vojáka OS ČR v NSP. Jedná se o otevřenou databázi povolání spravovanou Ministerstvem práce a sociálních věcí ČR, která umožňuje náhled a export dat z databáze více než 27 tisíc kompetencí. NSP obsahuje Centrální databázi kompetencí (CDK) popisující požadavky na pracovníka formou požadovaných kompetencí pro účely definování kvalifikačních požadavkử ${ }^{17}$.

NSP dělí kompetence na tzv. měkké kompetence („soft competence“), které jsou souborem požadavků potřebných pro kvalitní výkon jednotky práce, nezávislých na konkrétní odbornosti, ale na komplexních schopnostech člověka. Dále NSP obsahuje obecné dovednosti ("generic hard competence"), které jsou souborem obecných požadavků potřebných pro výkon práce, které zcela výhradně nesouvisí s určitou profesí. Obě kompetence mají prưřezový charakter a jsou napříc obory přenositelné a uplatnitelné. Další dělení podle NSP je na odborné znalosti („specific hard competence“), které označují teoretické vědomosti požadované pro výkon určité pracovní činnosti nebo souboru pracovních činností a odborné dovednosti („technical hard competence and knowledge“), které označují praktické dovednosti požadované pro výkon určité pracovní činnosti nebo souboru pracovních činností. Jedná se o schopnost aplikovat teoretické vědomosti v praxi.

Kompetenční model NSP na obrázku 3 Ize popsat jako strukturovanou množinu kompetencí, zahrnující oblast měkkých i odborných kompetencí, kde jsou jednotlivé kompetence, prípadně oblasti kompetencí, klasifikovány a jsou pro ně definovány úrovně, kterých mohou kompetence dosahovat. Klasifikace má hierarchickou strukturu, umožňuje komunikaci s dalšími systémy, které využívají kompetence ${ }^{18}$.

17 Národní soustava povolání [online]. Praha: Ministerstvo práce a sociálních věcí, 2017. Dostupné z: https:// nsp.cz/

18 Ref. 17. 


\section{Struktura kompetenčního modelu NSP}

\section{Měkké kompetence}

\section{Obecné dovednosti}

Odborné znalosti a dovednosti

Obrázek č. 3: Struktura kompetenčního modelu NSP

Zdroj: Národní soustava povolání [online].

Pro konkrétní podmínky OS ČR, resp. AČR, disponuje NSP katalogem povolání v rámci odborného směru ozbrojené síly a bezpečnostní sbory. Pro oblast AČR jsou hodnostní sbory rozděleny do 4 kvalifikačních úrovní $(3,4,6$ a 7) odrážejících náročnost požadavků kladených na jejich vykonavatele. Pro kategorii měkkých kompetencí je v současnosti uváděno 5 konkrétních kompetencí, přestože katalog jich obsahuje 15. Dále pro kategorii obecných dovedností je uváděno 5 konkrétních kompetencí, přestože katalog jich obsahuje 8 , a pro kategorii odborných znalostí a dovedností je uváděno 23 konkrétních kompetencí, přestože katalog umožňuje výběr až ze 113 kompetencí.

V rámci zkoumání možnosti konkrétní aplikace modelu kompetencí v NSP do podmínek AČR bylo provedeno srovnání všech 15 měkkých kompetencí uvedených v katalogu NSP a 10 služebních schopností, dovedností a vlastností uvedených v části 3. prílohy $\mathrm{k}$ vyhlášce č. 189/2015 Sb., o postupu při služebním hodnocení vojáků a jeho hlediscích. Měkké kompetence jsou v NSP řazeny do úrovní 0 až 5, přičemž nominální hodnota bodového ohodnocení vyjadřuje míru složitosti a komplexnosti ve zvládání kompetence.

Jako kritérium pro porovnání byly zvoleny relevantní dovednosti v rámci hodnocené oblasti, které Ize přiřadit k odpovídající měkké kompetenci. Výsledky komparativní analýzy jsou uvedeny $v$ tabulce 2 .

Tabulka č. 2: Komparativní analýza služebního hodnocení vojáka a NSP

\begin{tabular}{|c|c|c|c|c|}
\hline \multicolumn{2}{|c|}{$\begin{array}{l}\text { Relevantní schopnosti, dovednosti a vlastnosti v rámci hod- } \\
\text { nocené oblasti dle služebního hodnocení vojáka }\end{array}$} & \multicolumn{2}{|c|}{ Model kompetencí v NSP } & \multirow[b]{2}{*}{$\begin{array}{l}\text { Počet } \\
\text { shod }\end{array}$} \\
\hline $\begin{array}{l}\text { P.č. dle části } 3 \\
\text { přílohy vyhlášky } \\
\text { č. 189/2015 Sb. }\end{array}$ & $\begin{array}{l}\text { Název hodnocené schopnos- } \\
\text { ti, dovednosti a vlastnosti }\end{array}$ & $\begin{array}{l}\text { Kód dle } \\
\text { NSP }\end{array}$ & $\begin{array}{l}\text { Název měkké } \\
\text { kompetence }\end{array}$ & \\
\hline 5. & Komunikační schopnosti, akceptace jiných názorů & \multirow{2}{*}{$\mathrm{a} 01$} & \multirow{2}{*}{$\begin{array}{l}\text { Efektivní } \\
\text { komunikace }\end{array}$} & \multirow{2}{*}{2} \\
\hline 10. & Navazování a udržování kontaktů & & & \\
\hline 5. & Schopnost týmové práce & \multirow{2}{*}{$\mathrm{a} 02$} & \multirow{2}{*}{$\begin{array}{l}\text { Kooperace } \\
\text { (spolupráce) }\end{array}$} & \multirow{2}{*}{2} \\
\hline 10. & Kooperace & & & \\
\hline 8. & Tvořivost & $\mathrm{a} 03$ & Kreativita & 1 \\
\hline
\end{tabular}




\begin{tabular}{|c|c|c|c|c|}
\hline \multicolumn{2}{|c|}{$\begin{array}{l}\text { Relevantní schopnosti, dovednosti a vlastnosti v rámci hod- } \\
\text { nocené oblasti dle služebního hodnocení vojáka }\end{array}$} & \multicolumn{2}{|c|}{ Model kompetencí v NSP } & \multirow{2}{*}{$\begin{array}{l}\text { Počet } \\
\text { shod }\end{array}$} \\
\hline $\begin{array}{l}\text { P.č. dle části } 3 \\
\text { prílohy vyhlášky } \\
\text { č. 189/2015 Sb. }\end{array}$ & $\begin{array}{l}\text { Název hodnocené schopnos- } \\
\text { ti, dovednosti a vlastnosti }\end{array}$ & $\begin{array}{l}\text { Kód dle } \\
\text { NSP }\end{array}$ & $\begin{array}{l}\text { Název měkké } \\
\text { kompetence }\end{array}$ & \\
\hline 7. & Schopnost řešit složité úkoly & \multirow[b]{2}{*}{$\mathrm{a} 04$} & \multirow[b]{2}{*}{ Flexibilita } & \multirow[b]{2}{*}{2} \\
\hline 9. & $\begin{array}{l}\text { Schopnost vyrovnat se s neo- } \\
\text { čekávanými okolnostmi }\end{array}$ & & & \\
\hline 5. & Komunikační schopnosti, akceptace jiných názorů & \multirow[b]{2}{*}{$\mathrm{a} 05$} & \multirow{2}{*}{$\begin{array}{l}\text { Uspokojování } \\
\text { zákaznických } \\
\text { potřeb }\end{array}$} & \multirow[b]{2}{*}{2} \\
\hline 10. & $\begin{array}{l}\text { Navazování a udržování kontak- } \\
\text { tů, vnímavost vůči ostatním }\end{array}$ & & & \\
\hline 1. & Plnění povinností & $\mathrm{a} 06$ & Výkonnost & 5 \\
\hline 2. & $\begin{array}{l}\text { Úroveň uplatňování odborných vědo- } \\
\text { mostí a praktických zkušeností }\end{array}$ & \multirow{4}{*}{$\mathrm{a} 06$} & \multirow{4}{*}{ Výkonnost } & \multirow{4}{*}{5} \\
\hline 3. & $\begin{array}{l}\text { Zvyšování vlastní výkonnosti a podí- } \\
\text { lu na odstraňování nedostatků }\end{array}$ & & & \\
\hline 4. & $\begin{array}{l}\text { Schopnost účelně a hospodárně využí- } \\
\text { vat svěřené prostředky a dobu služby }\end{array}$ & & & \\
\hline 9. & $\begin{array}{l}\text { Schopnost vyrovnat se při plnění úkolů s neoče- } \\
\text { kávanými okolnostmi a se zátěžovými situacemi }\end{array}$ & & & \\
\hline 6. & Spolehlivost při plnění úkolů & \multirow{2}{*}{$\mathrm{a} 07$} & \multirow{2}{*}{ Samostatnost } & \multirow{2}{*}{2} \\
\hline 7. & Samostatnost a iniciativa při plnění úkolů & & & \\
\hline 7. & Schopnost řešit složité úkoly & \multirow{3}{*}{$\mathrm{a} 08$} & \multirow{3}{*}{$\begin{array}{l}\text { Řešení } \\
\text { problémů }\end{array}$} & \multirow{3}{*}{3} \\
\hline 8. & Předvídatelnost problémových situací & & & \\
\hline 9. & $\begin{array}{l}\text { Vyrovnat se při plnění úkolů s ne- } \\
\text { očekávanými okolnostmi }\end{array}$ & & & \\
\hline 4. & $\begin{array}{l}\text { Schopnost účelně a hospodárně využí- } \\
\text { vat svěřené prostředky a dobu služby }\end{array}$ & $\mathrm{a} 09$ & $\begin{array}{l}\text { Plánování a or- } \\
\text { ganizování práce }\end{array}$ & 1 \\
\hline 1. & Plnění povinností & \multirow{3}{*}{ a10 } & \multirow{3}{*}{$\begin{array}{l}\text { Celoživotní } \\
\text { učení }\end{array}$} & \multirow{3}{*}{3} \\
\hline 2. & $\begin{array}{l}\text { Úroveň uplatňování odborných vědo- } \\
\text { mostí a praktických zkušeností }\end{array}$ & & & \\
\hline 3. & Iniciativa a aktivita při zvyšování vlastní výkonnosti & & & \\
\hline 3. & Iniciativa a aktivita při zvyšování vlastní výkonnosti & \multirow{3}{*}{ a11 } & \multirow{3}{*}{ Aktivní prístup } & \multirow{3}{*}{3} \\
\hline 5. & Spolupráce v týmu & & & \\
\hline 7. & Samostatnost a iniciativa při plnění úkolů & & & \\
\hline 9. & Schopnost vyrovnat se se zátěžovými situacemi & a12 & Zvládání zátěže & 1 \\
\hline
\end{tabular}




\begin{tabular}{|c|c|c|c|c|}
\hline \multicolumn{2}{|c|}{$\begin{array}{l}\text { Relevantní schopnosti, dovednosti a vlastnosti v rámci hod- } \\
\text { nocené oblasti dle služebního hodnocení vojáka }\end{array}$} & \multicolumn{2}{|c|}{ Model kompetencí v NSP } & \multirow{2}{*}{$\begin{array}{l}\text { Počet } \\
\text { shod }\end{array}$} \\
\hline $\begin{array}{l}\text { P.č. dle části } 3 \\
\text { prílohy vyhlášky } \\
\text { č. } 189 / 2015 \text { Sb. }\end{array}$ & $\begin{array}{l}\text { Název hodnocené schopnos- } \\
\text { ti, dovednosti a vlastnosti }\end{array}$ & $\begin{array}{l}\text { Kód dle } \\
\text { NSP }\end{array}$ & $\begin{array}{l}\text { Název měkké } \\
\text { kompetence }\end{array}$ & \\
\hline 8. & Analytické schopnosti a úsudek & \multirow{2}{*}{ a13 } & \multirow{2}{*}{$\begin{array}{l}\text { Objevování } \\
\text { a orientace } \\
\text { v informacích }\end{array}$} & \multirow{2}{*}{2} \\
\hline 2. & $\begin{array}{l}\text { Úroveň uplatňování odborných vědo- } \\
\text { mostí a praktických zkušeností. }\end{array}$ & & & \\
\hline 5. & $\begin{array}{l}\text { Schopnost týmové práce, komunikační } \\
\text { schopnosti, akceptace jiných názorů }\end{array}$ & \multirow{2}{*}{ a14 } & \multirow{2}{*}{$\begin{array}{l}\text { Vedení lidí } \\
\text { (leadership) }\end{array}$} & \multirow{2}{*}{2} \\
\hline 10. & Vliv na mezilidské vztahy na pracovišti & & & \\
\hline 10. & $\begin{array}{l}\text { Navazování a udržování kontak- } \\
\text { tů, vnímavost vůči ostatním }\end{array}$ & a15 & $\begin{array}{l}\text { Ovlivňování } \\
\text { ostatních }\end{array}$ & 1 \\
\hline
\end{tabular}

Na základě podrobného studia služebního hodnocení vojáka Ize vyvozovat, že se v tomto případě se jedná o hodnocení prokazování kompetencí. V rámci porovnání relevantních dovedností v rámci hodnocené oblasti dle služebního hodnocení vojáka a seznamu měkkých kompetencí v NSP se potvrdilo, že tyto oblasti Ize vzájemně provázat. Byla nalezena shoda u všech hodnocených dovedností ve služebním hodnocení a měkkých kompetencí uvedených v NSP.

\section{DISKUSE}

Při zkoumání možnosti aplikace měkkých kompetencí definovaných v NSP do podmínek řízení kariér vojáků Ize shledat, že stávající situace v této oblasti je nesystémová. Měkké kompetence nejsou v rezortu MO ukotveny, veškerá personální práce se děje pouze na základě kvalifikačních předpokladů a odborných požadavků, jejich taxativní vlastnictví na konkrétní pozici není v popisu služebního místa vojáka uvedeno. Pouze ve 4 případech analyzovaného vzorku popisů služební činnosti vojáka byly stanoveny konkrétní kompetence jako: schopnost flexibilního a tvưrčího přistupu k plnění úkolů a komunikační dovednosti. Měkké kompetence jsou částečně zmíněny ve služebním hodnocení vojáka, ale jaké úrovně na dané stupnici hodnocení (škály) má konkrétní voják dosáhnout, není stanoveno ${ }^{19}$. Navíc je na tomto místě potřebné zdůraznit stávající disproporci mezi rejstříkem kompetencí uvedeným v CDK a skutečně uváděnými kompetencemi $v$ NSP. Tato skutečnost koresponduje $s$ výsledky předchozího výzkumu ${ }^{\mathbf{2 0}}$, který se mimo

19 Vyhláška č. 189/2015 Sb., o postupu při služebním hodnoceni vojáků a jeho hlediscích.

20 SAIBERT Richard. Strategické prístupy k prípravě vojenských profesionálů pro budoucí operace. Brno, 2019. Disertační práce. Univerzita obrany v Brně. 
jiné zabýval i otázkou tvorby kompetenčního modelu NSP a metodologií stanovování kompetencí.

Definice ideálního kandidáta na služební místo vojáka ve vztahu k měkkým kompetencím neexistuje, pro jejich stanovení není aplikován žádný relevantní nástroj a současný systém není schopen reflektovat specifika jednotlivých vojenských odborností. Ve výsledku dochází ke stavu, kdy není využíván plný rozsah efektivních nástrojů pro řízení lidských zdrojů podle kompetencí (obrázek 2), který slučuje jednotlivé personální procesy do komplexního systému, ve kterém jsou jednotlivé funkce rrízení lidských zdrojů integrovány modelem profesní kompetence. Ačkoliv potenciál možného využití vzájemné provázanosti měkkých kompetencí uvedených v NSP a služebních schopností, dovedností a vlastností uvedených ve služebním hodnocení vojáka byl v rámci výzkumu identifikován.

Vnitřní předpisy rezortu MO vymezují roli služebních orgánů odpovědných za správu vojenských oborů a odborností v systému definování požadavků na kompetence víceméně pouze z pohledu výběru vojáků z povolání do vzdělávacích a výcvikových aktivit ke splnění kvalifikačních předpokladů a kvalifikačních požadavků. Žádná role vztahující se k definování či přiřazování složek kompetencí dle kompetenčního modelu NSP v těchto vnitřních předpisech neexistuje. Pozice odpovědných orgánů při stanovování kompetencí je v porovnání s velitelskými orgány jednotlivých stupňů v systému řizení kariér nedostatečná. Poměrně výstižná je odpověd' respondenta, který shrnuje stav v této oblasti následovně: „Tak, jako se pořizuje vojenská technika s určitými parametry, stejným způsobem se pořizuje voják (kvalifikační a odborné požadavky, kompetence). Jako gestoři navrhujeme kvalifikační požadavky, které zasíláme velitelům k vyjádření. Kompetence není kam zapsat, jaksi na to není nikde žádná kolonka."

Zjištění ve vztahu k právním a vnitřním přepisům naznačují, že problém je v koncepčním vymezení postavení těchto služebních orgánů. Předpisy jsou složitě strukturované, postrádají systém, problematika je roztřištěná a není ujednoceno názvosloví. Za zásadní Ize považovat absenci předpisu, který by byl ucelenou metodickou pomůckou pro služební orgány odpovědné za správu vojenských odborností.

Na základě uvedených zjištění Ize konstatovat, že v rámci rezortu MO není aplikován systém uplatňování měkkých kompetencí vyššího důstojníka OS ČR.

\section{SYSTÉMOVÝ PŘíSTUP}

Soubor návrhů a doporučení k zavedení systémového přístupu ke stanovování a hodnocení kompetencí vyšších důstojníků OS ČR je založen na implementaci kompetenčního modelu, resp. uvedených kompetenčních požadavků. Pro objasnění a zarámování kontextu návrhů a doporučení je navržen model systémového přístupu k definování a hodnocení kompetencí vyšších důstojníků OS ČR, jehož jádrem je popis služebního místa vojáka, na nějž navazují související personální procesy (obrázek č. 4).

Základní funkce vzájemných relací modelu:

- identifikace a průběžná aktualizace souborů kompetenčních požadavků podle kompetenčního modelu NSP (gestor Sekce státního tajemníka MO, AP AČR); 
- vytvoření databáze kompetencí a její propojení (implementace) s popisem služebního místa vojáka v ISSP;

- propojení popisu služebního místa se služebním hodnocením vojáka, generování a zpracování obou dokumentů v ISSP;

- propojení výsledků služebního hodnocení vojáka s plánem vzdělávání v ISSP za účelem př́pravy vojáka pro jeho kariérní růst podle kompetencí a výběr ideálních kandidátů na konkrétní služební místa;

- aktualizace náplní jednotlivých studijních programů podle potřeb OS ČR z hlediska systematického rozvoje žádoucích klíčových kompetencí.

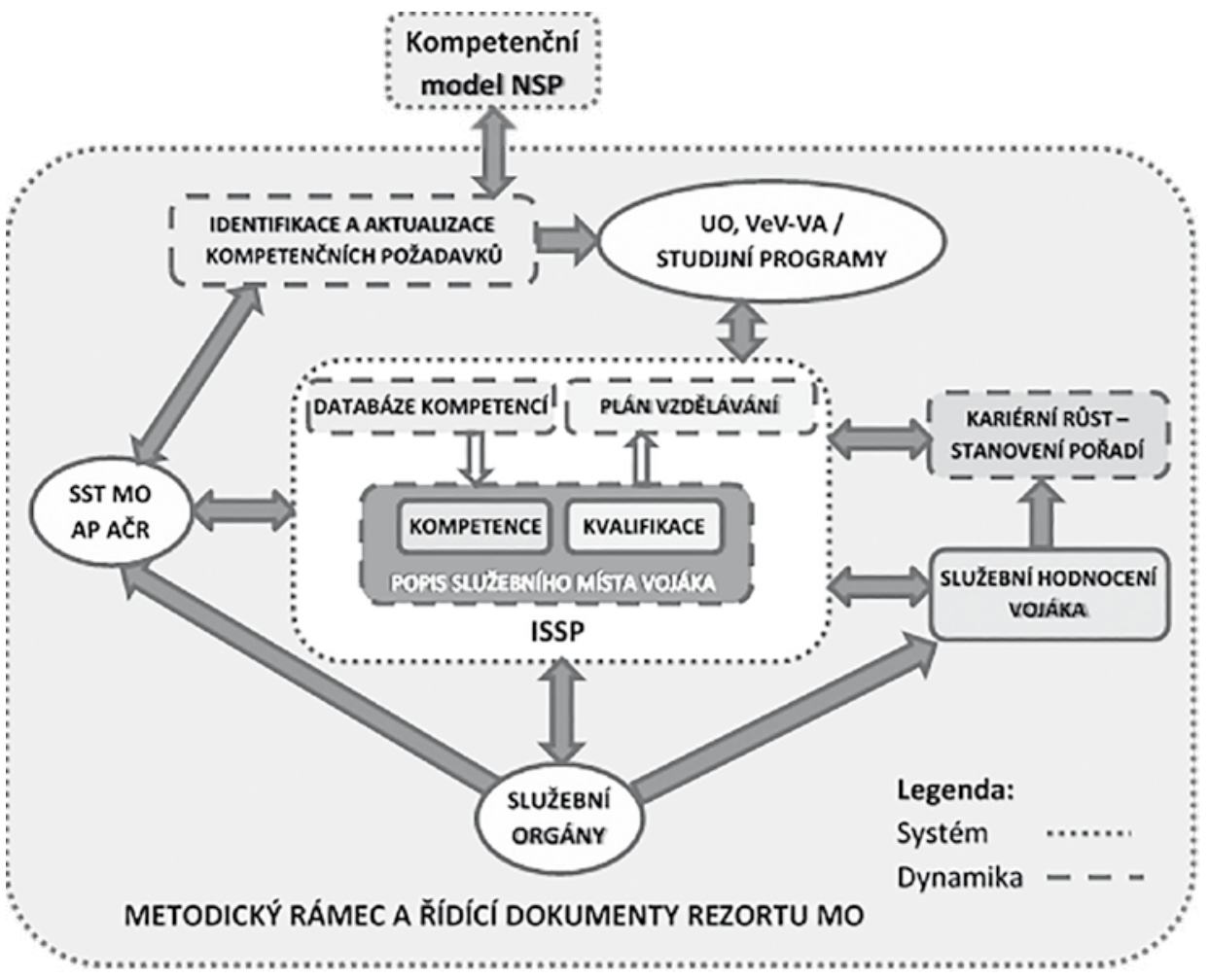

Obrázek č. 4: Model systémového přístupu k definování kompetencí Zdroj: vlastní zpracování

Navržený model systémového přístupu k definování kompetencí integruje oblasti, pro které jsou definovány níže uvedené návrhy a doporučení. 


\subsection{Uplatnění kompetenčního modelu NSP v podmínkách rezortu MO}

Uvedené návrhy směřují především ke snaze popsat služební místo vojáka z povolání, tedy vyššího důstojníka OS ČR. Na základě dosavadních zjištění Ize považovat za komplexní, a tedy i optimální řešení z pohledu kompetenčního přístupu k řízení personálu v podmínkách rezortu MO, variantu úplné aplikace kompetenčního modelu NSP. Toto rešení by vyžadovalo průběžnou aktualizaci všech souborů kompetenčních požadavků podle kompetenčního modelu NSP, který umožní popsat konkrétní kombinaci vědomostí, dovedností a dalších charakteristik, až na podrobnost popisu služebního místa vojáka.

$\mathrm{Na}$ základě identifikované disproporce, kdy není využíváno plného rozsahu nabídky CDK v NSP, bude nutné u hodnostních sborů doplnit obsah kompetencí v jednotlivých kategoriích, například párováním, príbuzností, klastrováním jednotlivých kompetencí, hledáním dle synonym či klasifikováním nových kompetencí podle potřeb OS ČR. Následně budou stanoveny kvalifikační úrovně a jejich deskriptory, jež vymezí očekávané výsledky práce a schopnosti spojované s danou kvalifikační úrovní.

Uvedené řešení má tu zásadní výhodu, že staví na již existujícím kompetenčním modelu NSP, který se vyznačuje svou komplexností, snadnou aplikovatelností, integritou a flexibilitou. Jeho prínos Ize spatřovat zejména při tvorbě popisů služebních míst vojáků, služebního hodnocení jejich výkonu, tvorbě plánu vzdělávání, aktualizaci náplní jednotlivých studijních programů, výběru vojáků pro jejich další kariérní růst a výběr ideálních kandidátů na konkrétní služební místa, a to především z hlediska systematického rozvoje žádoucích klíčových kompetencí.

Jako rizikové lze u této varianty identifikovat značnou časovou, personální či technickou náročnost, zejména pak v souvislosti se skutečným využíváním kompetencí poskytovaných rejstříkem CDK pro potřeby popisu kompetenčního modelu v rámci uvedených kategoriích kompetencí.

Další možností uplatnění kompetenčního modelu NSP přestavuje jeho částečná (parciální) aplikace. Tato varianta reaguje na úplnou absenci jedné ze složek kompetenčních požadavků na personál v rezortu $\mathrm{MO}$, což jsou měkké kompetence. $\mathrm{V}$ tomto prípadě se do popisu služebního místa vojáka doplní pouze měkké kompetence. Zásadním krokem tohoto návrhu je identifikace souboru měkkých kompetencí, případně více variant těchto souborů, které musí být sledovatelné, měřitelné, hodnotitelné, přistupné změně a rozvoji pro požadovaný výkon vojáka. Následně bude možno přistoupit $\mathrm{k}$ jejich zapracování do popisu služebního místa důstojníka. Identifikace a stanovení konkrétních kompetencí na konkrétním služebním místě vojáka vyžaduje jeho dokonalou znalost, aby bylo možno definovat úrovně jednotlivých kompetencí na základě využití škál. Navrhované nástroje $k$ identifikaci kompetencí jsou uvedeny v následujícím pořadí:

1. Rozhovor nebo metoda kritických situací s využitím zkušeností nadřizených služebních orgánů.

2. Panel expertů, který vychází z doporučení konkrétních vojáků, kteří již na daném služebním místě působí nebo $v$ minulosti působili.

3. Dotazníkový průzkum.

4. Analýza pracovních úkolů nebo využití generických databází kompetencí pro obdobné pracovní pozice. 


\section{Zkušenosti ze zahraničních armád.}

Vzhledem k současné zažité praxi, kdy popis služebního místa vojáka je zpracováván formou vyplnění textového dokumentu, zpravidla nadřizeným vojáka a až následně je na AP AČR zadán do ISSP, je tato implementace proveditelná. Bude nezbytné stanovit, do které části popisu služebního místa vojáka měkké kompetence vložit a zabezpečit dostupnost katalogu měkkých kompetencí pro zpracovatele. $V$ prípadě technického rozvoje ISSP, který by umožnil zpracovateli popisu služebního místa vojáka pracovat př́mo v ISSP, by bylo zadání měkkých kompetencí z př́slušného souboru povinné.

\subsection{Návrh konkrétního uplatnění souboru měkkých kompetencí ve služebním hodnocení vojáka}

Výše uvedený návrh v oblasti popisu služebního místa vojáka se musí promítnout i ve služebním hodnocení vojáka. $V$ prípadě, že jsou na konkrétním služebním místě vojáka stanoveny konkrétní kompetence, musí být jejich dosahování nebo plnění následně vyhodnoceno za účelem jejich rozvoje. Potenciál využití vzájemné provázanosti měkkých kompetencí uvedených v NSP a služebních schopností, dovedností a vlastností uvedených ve služebním hodnocení vojáka byl identifikován a rozpracován v kapitole č. 3, Uplatnění kompetenčního modelu v podmínkách OS ČR (viz tabulka 2).

Propojení zdrojů kompetencí s popisem služebního místa vojáka Ize realizovat doplněním ISSP o databázi měkkých kompetencí a následně propojením popisu služebního místa se služebním hodnocením vojáka. Zvolené kompetence a jejich požadované úrovně by se pak automaticky generovaly do služebního hodnocení vojáka, které by vedoucí zaměstnanec zpracoval v ISSP, bez nutnosti dalšího přenosu dat k personálním orgánům. Toto řešení umožní přejít od jednotného $k$ diferencovanému způsobu hodnocení.

\subsection{Doporučení v oblasti koncepční a normotvorné}

Implementace systémového přístupu ke stanovování a hodnocení kompetencí vyšších důstojníků OS ČR bude vyžadovat řadu koncepčních kroků. Jedná se především o posílení působnosti služebních orgánů odpovědných za správu vojenských oborů a odborností v oblasti stanovování požadavků na konkrétní kompetence vyšších důstojníků a jejich role při výběru těchto vojáků do vzdělávacích a výcvikových aktivit. Uvedená doporučení Ize realizovat lepším využíváním všech možností ISSP, zejména v oblasti prípravy personálu, přípravy studijních programů a stanovení konkrétních odborných požadavků, ale i ovlivněním procesu jejich následné realizace.

Důležitým subjektem systému řízení kariér jsou kariéroví manažeři AP AČR. Tito manažeři jsou spojovacím prvkem mezi služebními orgány, potřebami AČR a vojáky. Odpovědné orgány musí $k$ úspěšné realizaci navržených doporučení lépe využívat podporu z úrovně kariérových manažerů. 
Realizace těchto doporučení je podmíněna vytvořením metodického rámce a řídících dokumentů pro činnost služebních orgánů odpovědných za správu vojenských oborů a odborností. Tyto činnosti musí být v systému rrízení lidských zdrojů jednotně chápány a realizovány. Konkrétním návrhem reflektujícím zjištění ze strukturovaných rozhovorů je vytvoření metodické pomůcky formou normativního výnosu MO pro činnost služebních orgánů odpovědných za správu vojenských oborů a odborností za účelem jednotného chápání, detailního popisu a realizace jednotlivých činností.

$\checkmark$ dalším kroku je nezbytné revidovat některé vnitřní předpisy. Jedná se konkrétně o ujednocení názvosloví v RMO č. 64/2015 Věstníku Působnost služebních orgánů v personální práci a RMO č. 2/2019 Věstníku Zásady tvorby systemizovaných míst, a dále o aktualizaci NVMO č. 72/2010 Věstníku Zásady pro zpracování tabulky počtů organizačního celku rezortu Ministerstva obrany či přilohy 2 k RMO č. 2/2019 Věstníku Zásady tvorby systemizovaných míst, tak aby odpovídaly nové organizační struktuře rezortu $\mathrm{MO}$ (AČR).

$\checkmark$ navazujících etapách bude potřebné vytvořit relevantní předpisy, které by stanovily způsob a postupy implementace kompetenčního modelu NSP.

\section{ZÁVĚR}

Prezentované návrhy a doporučení poskytuji dílčí přínos v oblasti využití efektivních nástrojů pro řízení lidských zdrojů podle kompetencí, které se vyznačují svou komplexností, snadnou aplikovatelností, integritou a flexibilitou. Orgány odpovědné za řízení lidských zdrojů a vzdělávání tak dostávají do rukou vymezení, jakým směrem systémově rozvíjet kompetence vyšších důstojníků OS ČR, zejména při tvorbě popisů služebních míst vojáků, služebního hodnocení jejich výkonu, tvorbě plánu vzdělávání, aktualizaci náplní jednotlivých studijních programů a výběru vojáků pro jejich kariérní růst. Návrhy současně naznačují možný směr technického rozvoje ISSP jako moderního nástroje řízení lidských zdrojů podle kompetencí. Požadavky na soubory kompetencí musí vycházet z potřeb OS ČR a být provázány se systémem řízení lidských zdrojů, který slučuje jednotlivé personální procesy do komplexního systému, ve kterém jsou jednotlivé funkce řízení lidských zdrojů integrovány modelem profesní kompetence.

Autoři: $\quad$ Plk. gšt. Ing. Jaroslav Kuba, narozen v roce 1971. Absolvent Vojenské akademie v Brně, obor výzbrojně technický, zbraně a munice (1995) a kurzu generálního štábu na Centru bezpečnostních a vojenskostrategických studií, Univerzity obrany v Brně (2020). Po dobu svého působení v Armádě České republiky zastával různé štábní funkce $v$ oblasti logistiky a kontroly hospodaření s majetkem státu. Má také zkušenostmi ze zahraničních operací a aktuálního působení ve stálé pracovní skupině při ÚKŠ ČR. V současné době pracuje jako náčelník odboru logistiky štábu Velitelství pro operace.

Ing. Richard Saibert, Ph.D., narozen v roce 1969. Absolvent Vysoké vojenské školy ve Vyškově (1991) a Univerzity obrany v Brně (2019). Po dobu svého 
působenív Armádě České republiky zastával různé velitelské a štábní funkce. $\checkmark$ rámci rezortu MO se podílel na řešení otázek souvisejících se zabezpečením obrany státu. Má také zkušenostmi ze zahraničních pracovišt' a z civilního sektoru, a to $v$ oblasti projektového řizení a veřejných zakázek. $V$ současné době pracuje jako akademický pracovník na Centru bezpečnostních a vojenskostrategických studií Univerzity obrany v Brně. V oblasti prípravy vojenského personálu publikuje souvisejici odborné články.

Jak citovat: KUBA, Jaroslav a Richard SAIBERT. Stanovování a hodnocení kompetencí důstojníka ozbrojených sil České republiky. Vojenské rozhledy. 2020, 29 (4), 065-083. ISSN 1210-3292 (print), 2336-2995 (on-line). Available at: www. vojenskerozhledy.cz 


\section{Střelba s jednotným dopadem střel a možnosti využití v Armádě České republiky}

\section{Multiple round simultaneous impact fires and possibilities of its application in Czech Army}

\section{Michal Šustr, Ladislav Potužák, Martin Blaha, Jan Ivan}

Abstrakt: CClánek se zabývá možností využití dělostřelecké palby se současným dopadem střel, a to pro palebné komplety dělostřelectva aktuálně zavedené v Armádě České republiky. Klade si za cíl analyzovat stávající dělostřelecké postupy a v návaznosti na to popsat možnosti, přínosy a případná negativa palby se současným dopadem střel. $V$ závěru jsou stanoveny konkrétní požadavky, které je nutné naplnit pro efektivní využití palby se současným dopadem střel s aktuálně zavedenými dělostřeleckými zbraňovými komplety.

Abstrakt: The article deals with the possibility of using artillery fire with the multiple round simultaneous impact, for artillery weapon systems currently used in the Army of the Czech Republic. It aims to analyze the existing artillery procedures and then describe the possibilities, benefits and possible negatives of multiple rounds simultaneus impact fires. In the end, specific requirements are set that must be met for the effective use of fire with the simultaneous impact of missiles with currently used artillery weapon systems.

Klíčová slova: Dělostřelectvo; efektivnost; taktika; MRSI.

Keywords: Artillery; efficiency; tactics; MRSI. 


\section{ÚVOD}

Včasná, účinná a takticky výhodná dělostřelecká palba může $v$ probíhající operaci představovat klíčový prvek $\mathrm{k}$ dosažení stanovených cílů. Plánování a koordinace dělostřeleckých paleb $v$ rámci společné palebné podpory představuje jednu z hlavních částí plánovacího procesu štábu úkolových uskupení. Cílem těchto procesů je dosáhnout schopnosti poskytovat efektivní dělostřeleckou palebnou podporu v rámci uceleného konceptu společných paleb (JFS - Joint Fires Support).

Tyto činnosti a procesy vedou $\mathrm{k}$ naplnění smyslu bojové činnosti dělostřelectva, kterou je vyřazení neprátelských cílů z boje efektivní dělostřeleckou palbou. Palba je tím efektivnější, čím větší ztráty nepř́teli způsobí a čím spolehlivěji a na delší dobu ho vyřadí z boje. Efektivnosti palby se dosahuje včasností, účinností a taktickou výhodností1 ${ }^{1}$.

Včasnost, účinnost a taktická výhodnost, jsou tedy klíčové faktory celkové efektivnosti provedených dělostřeleckých paleb. Abychom mohli uvažovat o postřelování cílů se současným dopadem střel (MRSI - Multiple Rounds Simultaneous Impact) při využití stávajících zavedených dělostřeleckých zbraňových kompletů (děl a minometů), je nutné posoudit, jakých výhod bude při využití tohoto způsobu dosaženo. $Z$ tohoto důvodu je nejprve nutné odpovědět na otázku, zda se využitím palby se současným dopadem střel zlepší včasnost, účinnost a taktická výhodnost dělostřelecké palby, respektive jaké nevýhody snižuje nebo eliminuje palba se současným dopadem střel oproti stávajícím postupům.

Z historického pohledu není palba se současným dopadem střel žádnou novinkou. MRSI pouze rozvijí rozšířený postup TOT (Time On Target). Metodika TOT umožňuje zasáhnout cíl několika střelami současně, př̀i použití několika děl nebo prostředků společné palebné podpory.

Tuto techniku vyvinula britská armáda během druhé světové války. Důstojníci dělostřelectva si synchronizovali hodinky podle rádia BBC. Následně každá dělostřelecká jednotka zahájila palbu v takový okamžik, aby $v$ daný čas dopadly střely do cíle 2 .

Dvouranná TOT byla prováděna již v 60 . letech 20 . století, kdy dobře vycvičené obsluhy předváděly své dovednosti. V červnu 1988 americká Human Engineering Laboratory, dnes známá jako Army Research Laboratory, demonstrovala tř́rannou TOT schopnost se $155 \mathrm{~mm}$ samohybnou houfnicí a v červnu 1991 dokonce čtyřranou TOT ${ }^{3}$.

Rovněž využití tzv. sekvenční střelby hlavňových děl není novinkou. Dělostřelecké obsluhy prezentovaly svou vycvičenost tím, že byly schopny vystřelit 2 rány $z$ jednoho děla a obě dopadly do cíle ve stejný okamžik. Toho dosahovaly tím, že první ránu vystřelily horní skupinou úhlů (strmou drahou) a druhou spodní skupinou úhlů (oblou drahou). Okamžik druhého výstřelu se vypočítal jako rozdíl doby letu první a druhé střely ${ }^{4}$.

1 DĚL-2-1. Pravidla střelby a ř́zení palby. Praha: MO, 2019.

2 The Develompment of Artillery Tactics and Equipment, Brigadier Al Pemberton, 1950, The War Office, $129 \mathrm{~s}$.

3 KOEGLER, T. M. Single Gun, Multiple Round, Time-on-target capability for advanced towed cannon artillery. Final rept., Army research lab aberdeen proving ground MD, 1995. ADA293479. $39 \mathrm{s.}$

4 The Develompment of Artillery Tactics and Equipment, Brigadier Al Pemberton, 1950, The War Office, $129 \mathrm{~s}$. 
MRSI vznikla na základě techniky TOT, jako studie MRTOT (Multiple Round Time On Target). Postupem času a vývojem nových technologií, zejména přechodem z ručního na motorický pohon udělování náměru hlavni, došlo k rozvoji TOT do podoby, jak ji známe dnes. MRTOT čtyř ran se současným dopadem střel jednoho děla do prostoru cíle dosáhlo stejného efektu jako TOT čety při vystřelení jedné rány každým jejím dělem ${ }^{5}$. Př́klad využití TOT je znázorněn na obrázku 1. Obrázek znázorňuje tři palebné baterie s rozdílnou dálkou cíle, municí, prvky střelby a dobou letu střely.
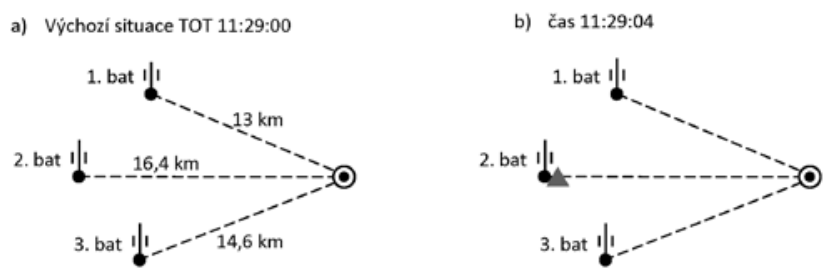

c) čas $11: 29: 10$

a) čas 11:29:15
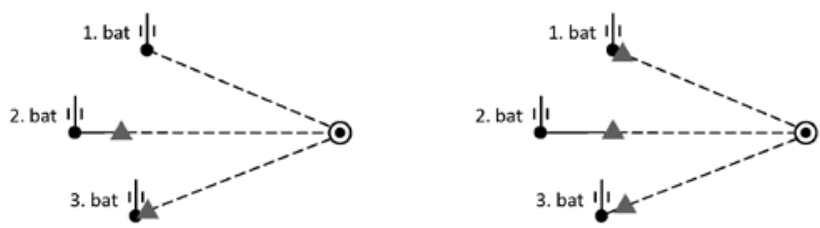

e) čas 11:29:40

f) Čas 11:30:00
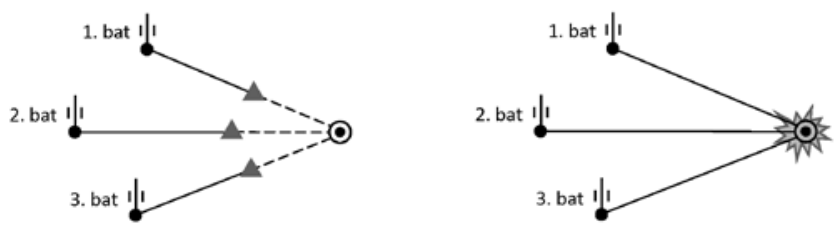

Obrázek č. 1: Příklad TOT

Zdroj: ${ }^{6}$

Co tedy vlastně je MRSI? MRSI je takový způsob vedení palby, při kterém jsou jednotlivé střely vystřeleny pod různými úhly náměru, při použití různých prachových náplní a tím i s různou dobou letu střely. Právě doba, po kterou se střela pohybuje v atmosféře,

5 KOEGLER, T. M. Single Gun, Multiple Round, Time-on-target capability for advanced towed cannon artillery. Final rept., Army research lab aberdeen proving ground MD, 1995. ADA293479. $39 \mathrm{~s}$.

6 Střelba se současným dopadem střel (MRSI). Brno, 2017. Diplomová práce. Univerzita obrany v Brně. Vedoucí práce pplk. Ing. Mgr. Martin Blaha, Ph.D. 
hraje klíčovou roli při stanovení počtu střel, které je zbraňový komplet schopen vystřelit tak, aby střely dopadly do cíle ve stejném okamžiku. Stručně řečeno jde tedy o to, dostat do prostoru cíle $z$ jednoho dělostřeleckého zbraňového kompletu co nejvíce střel, v co nejkratším čase, tak aby bylo dosaženo jejich současného dopadu do cíle.

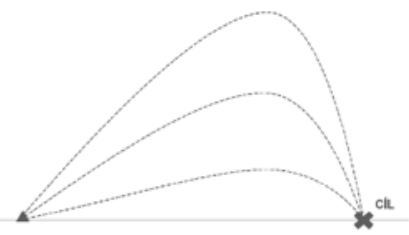

a) První výstřel

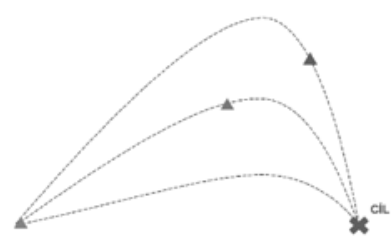

e) Třetí výstřel

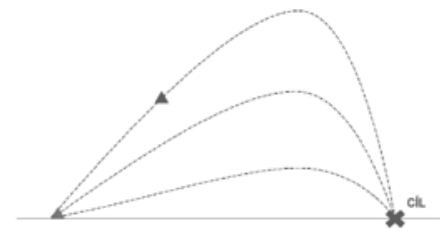

c) Druhý výstřel

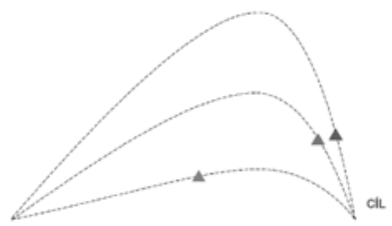

g) Průběh letu střel

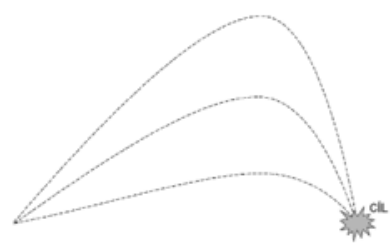

i) Současný dopad střel

Obrázek č. 2: Příklad MRSI

Zdroj: ${ }^{7}$

Současné dělostřelecké zbraňové komplety zavedené v AČR nedisponují schopností střelby se současným dopadem střel $v$ automatickém režimu vedení palby, přesto jsou schopny MRSI dosáhnout. Je však nezbytné stanovit podmínky, za jakých toho Ize dosáhnout, stanovit omezení a upravit bezpečnostní opatření pro obsluhu daného dělostřeleckého zbraňového kompletu, upravit metodiky pro činnost obsluhy a pro řizení palby.

7 Střelba se současným dopadem střel (MRSI). Brno, 2017. Diplomová práce. Univerzita obrany v Brně. Vedoucí práce pplk. Ing. Mgr. Martin Blaha, Ph.D. 
$\checkmark$ neposlední řadě je nutné posoudit, je-li vůbec takticky výhodné tento způsob vedení palby v manuálním režimu využívat.

\section{PREZENTACE ZJIŠTĚNÍ}

Současné postupy v dělostřelectvu AČR neznají MRSI. Dělostřelecké jednotky využívají pouze metodiku TOT, a to zejména při soustředěných a hromadných palbách na cíle větších rozměrů, respektive při rozdělení úseků cíle mezi více střílejících jednotek, případně v rámci společné palebné podpory mezi dělostřelectvo a letectvo. Zahájení palby jednotlivými palebnými jednotkami pak musí nastat $v$ takovém čase, aby střely dopadly do cíle současně. Tento způsob je velmi náročný na přípravu, koordinaci a řízení. Každá palebná jednotka má jiné palebné postavení a tím i jinou topografickou dálku, respektive počítanou dálku střelby na cíl. Rovněž složení munice nemusí být v daném okamžiku stejné u všech střílejících jednotek. Uvedené rozdíly způsobují rozdílnou dobu letu střely na cíl. Palba tak nemůže začít $v$ jednom okamžiku, ale vyžaduje naplánování časové posloupnosti. Praktické využití tohoto způsobu vedení palby v AČR však není v předpisech a publikacích zmiňováno.

Splnění požadavků na včasnost, přesnost a taktickou výhodnost se $v$ současné době mimo jiné dosahuje tím, že palbu vede potřebný počet jednotek po určitou dobu, během které vystřelí stanovený počet střel. Je nutné počítat $s$ tím, že jakákoli delší přítomnost palebných jednotek v palebném postavení (děl na palebných stanovištích) může vyvolat protiopatření protivníka a provedení odvetné palby (protibaterijní činnost). $Z$ uvedeného důvodu je vedení palby po delší dobu takticky nevýhodné. Prodlužováním činnosti v prostoru palebných stanovišt́ dělostřeleckých zbraňových kompletů, se zvyšuje šance na úspěšnou protibaterijní palbu protivníkem. Stejně tak ale může být takticky nevýhodné vedení palby velkým počtem děl. Při tomto způsobu použití dělostřeleckých jednotek dojde ke kumulaci dělostřeleckých zbraňových kompletů v prostoru palebných postavení a tím ke zvýšení demaskujicích příznaků činnosti dělostřelectva. Mǔže tak dojít k rozkrytí prostorů palebných postavení dělostřeleckých jednotek způsobené demaskujícími příznaky střelby a manévrem jednotek.

Neméně důležitým požadavkem na efektivnost palby je její účinnost. Jedním ze způsobů jak účinnost palby zvýšit je zvyšování její překvapivosti. Překvapivosti palby se $v$ současnosti dosahuje vhodným rozmístěním jednotek v prostoru palebných postavení, skrytým taktickým manévrem, správnou časovou koordinací paleb s podporovanými jednotkami, volbou počtu střílejících jednotek a způsobu postřelování cílů8.

Překvapivosti palby se dosáhne tehdy, jsme-li schopni připravit palebnou jednotku pro daný úkol skrytě a nepozorovaně a ve správný okamžik dopravit do prostoru cíle potřebné množství střel. Překvapivost palby se značně snižuje při potřebě provedení zastřilení a vedení účinné střelby palbou menším počtem děl.

8 DĚL-2-1. Pravidla střelby a řizení palby. Praha: MO, 2019. 
V současnosti využívané postupy a metodiky jsou zcela jistě správné a poskytují v daném okamžiku a za dané taktické situace, při dodržení všech pravidel pro vedení dělostřelecké palebné podpory, efektivní palbu. Mají však svá slabá místa:

- dlouhá doba činnosti palebných jednotek v prostoru palebných postavení;

- využívání velkého počtu dělostřeleckých zbraňových kompletů pro postřelování cílů;

- manévr v prostoru palebných postavení velkým počtem dělostřeleckých zbraňových kompletů;

- omezení překvapivosti palby.

Všechny výše zmíněné nedostatky řeší moderní dělostřelecké zbraňové komplety využitím palby se současným dopadem střel MRSI.

Jako první nedostatek standardního provedení dělostřelecké palby, byla uvedena dlouhá doba setrvání střílející jednotky v palebném postavení. Důvod pro její zkrácení můžeme najít již v období l. světové války. Pozemní nebo vzdušní pozorovatelé naváděli protibaterijní palby v rámci probíhajícího útoku nebo obranné činnosti. Jejich cílem bylo najít a následně rušit strílející dělostřelectvo protivníka tak, aby poskytovaná palebná podpora ztratila svou efektivitu, kontinuitu, přesnost a včasnost. Nutnost postřelování cílů větším počtem dělostřeleckých zbraňových kompletů představuje ideální okamžik, kdy může protivník na základě demaskujících příznaků střílejících děl a jejich manévru v prostoru palebných postavení rozkrýt sestavu dělostřeleckých jednotek.

Systém MRSI do značné míry zmiňované nedostatky eliminuje. $\mathrm{K}$ vedení palby na cíle s využitím MRSI jsou potřebné tři základní předpoklady:

- dělostřelecký zbraňový komplet schopný vést palbu dostatečnou rychlostí (tempo vedení palby);

- dělostřelecká munice disponující širokou škálou prachových náplní s různým dostřelem;

- systém řízení palby dělostřelectva, který je schopen potřebných výpočtů (byl naprogramován na zpracování dat pro výpočet prvků pro střelbu pro tento způsob postřelování cílů a je schopen tato data sdílet s jednotlivými palebnými komplety a zobrazovat je ve správném pořadí) ${ }^{9}$.

Dělostřelecké zbraňové komplety splňující tato kritéria a disponující schopností vedení palby MRSI, získávají výhodu v efektivnosti palby. Moderní dělostřelecké zbraňové komplety jsou schopné vystřelit 4 až 6 ran způsobem MRSI do 60 sekund. Při běžném palebném přepadu na pozorované cíle se využívá zpravidla sérií účinné střelby po $2-4$ ranách ráz na ráz na jeden cíl. Je-li cíl postřelovaný současnou palebnou baterií (8 děl), dopraví se do prostoru cíle na konci první minuty celkem 32 kusů munice $(8 \times 4)$. Po vypálení prvních 8 kusů má však nepřítel dalších přibližně 15 sekund na provedení opatření ke snížení účinku dělostřelecké palby (zaujetí skrytů). V případě technologicky vyspělého moderního dělostřeleckého zbraňového kompletu dokáže 5 děl dopravit do cíle stejné množství munice $(5 \times 6)$ ve stejném čase nebo 8 děl 48 kusů munice $(8 \times 6)$, avšak za poloviční až třetinovou dobu strávenou v palebném postavení. Palebné prostředky tak

9 Hu, Xin Jun, Hang Yu, Effectiveness Calculation of Multiple Rounds Simultaneous Impact Shooting Method Based on Monte Carlo Method, Applied Mechanics and Materials, 2013. 
mohou již po první minutě opouštět palebné postavení a minimalizovat tak například hrozbu realizace protibaterijní palby. V prípadě využití MRSI pak dopadne všech 48 střel do cíle současně a protivník tak nemá příležitost na provedený palebný přepad adekvátně reagovat. Efektivita palby je větší, protože její překvapivost narůstá.

Tyto teoretické úvahy vedly k návrhu realizace experimentu MRSI u zavedených zbraňových kompletů dělostřelectva manuálním způsobem. Cílem je především zvýšit překvapivost a tím i efektivnost palby.

Pro potřeby provedení palby MRSI jsou u AČR uvažovány $152 \mathrm{~mm}$ ShKH (samohybná kanonová houfnice), $120 \mathrm{~mm}$ minomet, $81 \mathrm{~mm}$ minomet. Pro realizaci projektu bylo nutné stanovit požadavky na činnosti jednotlivých členů obsluhy za dodržení bezpečnostních opatření při střelbě, upravit povelovou techniku, analyzovat dostřely a doby letu střel při využití jednotlivých náplní a stanovit optimální dostřely pro realizaci střelby MRSI s různým počtem střel. V neposlední řadě také analyzovat možnosti jednotlivých dělostřeleckých střelnic k provedení střelby MRSI, kdy musí například palebná postavení splňovat požadavky na vedení palby všemi náplněmi.

\section{DISKUSE}

\subsection{Jsou stávající palebné prostředky schopné vést palbu MRSI?}

Odpověd' na tuto otázku má dvě roviny, technickou a praktickou. Po technické stránce jsou zavedené dělostřelecké zbraňové komplety schopny vést palbu MRSI. Umožňují nastavovat náměr v potřebném rozsahu. Disponují municí, se kterou jsou schopné vést palbu na různé dálky s rozdílnou dobou letu střely. Z praktického hlediska je však nutné odpovědět na otázku, zda je obsluha schopná činnosti potřebné k provedení MRSI zvládnout a to v potřebném čase, při zachování přesnosti a dodržení bezpečnostních opatření. Fyzické možnosti a dispozice členů obsluhy a jejich secvičenost je faktor, který se významně promítá do výsledných časů při vedení palby. Na tyto otázky mají odpovědět naplánované a některé již provedené experimenty. Po vyhodnocení již provedených počátečních měření v rámci experimentů můžeme být bezpochyby optimističtí.

\subsection{Je takticky výhodné využívat palby MRSI?}

Při použití MRSI Ize nepochybně zvýšit překvapivost palby. Lze však pouze učinit kvalifikovaný odhad, že takto provedené palby způsobí větší ztráty a budou více pưsobit na psychiku a morálku protivníka. U manuální palby MRSI nelze počítat s časovým ziskem. Vedením palby MRSI bude jednotka kratší dobu v palebném postavení. Nutnost přenastavení dálky střelby může naopak způsobit několika sekundovou časovou ztrátu. 
Zde se proti sobě staví nárůst efektivity palby prostřednictvím její překvapivosti a čas potřebný na provedení palebného přepadu způsobený úpravou metodiky pro obsluhu dělostřeleckého zbraňového kompletu. Překvapivost palby a zvýšení efektivity zde predstavuje větší zisk. Palba MRSI nebude využívána vždy. Není vhodné ji zařazovat po provedeném zastřílení, kdy je překvapivost palby již promarněna. Palebné přepady prováděné s prvky pro střelbu získanými úplnou prípravou či přenosem palby na cíle, které nejsou v kontaktu při palebné prípravě, jsou vhodné pro palby MRSI a mohou tedy zabezpečit taktickou výhodu i prì manuálním režimu.

\section{ZÁVĚR}

Efektivita střelby je klíčovým požadavkem pro úspěšné splnění palebného úkolu a tím i pro celkovou úspěšnost podporovaných bojových operací. Manuální střelba MRSI predstavuje možnost jak získat taktické výhody v určitých fázích bojové činnosti a při plnění specifických palebných úkolů. Způsob vedení palby s jednotným dopadem střel není žádnou novinkou. Již v I. světové válce lze nalézt prvky využití tohoto způsobu vedení palby. Se zaváděním nových moderních dělostřeleckých zbraňových kompletů, a jejich schopností vést samostatně palbu MRSI i několika ranami, dává využití tohoto zpưsobu vedení palby zcela nový rozměr. Díky tomu je možné perspektivně využívat její přednosti v maximální možné mîre. Nová možnost jak využít pro tento způsob vedení palby i dělostřelecké jednotky bez moderních zbraňových kompletů může být při vedení palby na specifické cíle $v$ určitých fázích bojových operací velkou výhodou. Rovněž lze pozitivně hodnotit psychologický vliv na protivníka, při zjištění, že naše dělostřelecké jednotky jsou schopny vést takovou palbu manuálně. Ukazuje to totiž na nejvyšší stupeň sladěnosti a vysokou profesionalitu obsluh dělostřeleckých zbraňových kompletů a jejich schopnost poskytovat efektivní palebnou podporu manévrovým jednotkám.

Realizovatelnost tohoto způsobu palby musí být nejprve ověřena v praxi. $Z$ tohoto důvodu probíhají u Katedry palebné podpory ve spolupráci s příslušníky VeV-VA Vyškov a přislušníky dělostřeleckých útvarů experimenty, s cílem zjistit realizovatelnost manuálních paleb MRSI u dělostřelectva AČR.

Využití MRSI má pozitivní vliv na dílčí aspekty uvedených kličových faktorů, které ovlivňují konečnou efektivnost paleb. Jedná se zejména o:

- plánování paleb;

- flexibilitu systému řízení palby;

- analýzu cílů a výběr vhodných prostředků k jejich vyřazení;

- vysokou překvapivost palby;

- použití optimálního počtu palebných jednotek (dělostřeleckých zbraňových kompletů);

- volbu optimálního druhu a množství munice;

- stanovení nejvhodnějšího způsobu plnění palebného úkolu;

- využití fyzického a psychického účinku palby. 
Naopak jako negativní vlivy Ize hodnotit:

- nutnost zaškolení obsluh;

- náročnost na sladění obsluhy v průběhu manuální střelby MRSI;

- náročnost na př́pravu prvků pro střelbu bez systémů řízení palby.

Jakou výhodu tedy má zavedením manuální způsobu vedení MRSI? Předně to bude zvýšení efektivnosti palby. Zvýšení překvapivosti využitím palby MRSI je nesporné. Dopravíme-li do cíle celou (nebo většinu) kalkulovanou spotřebu střel současně bude okamžitý fyzický a psychologický efekt větší než v případě vedení palby ráz na ráz.

Článek vznikl na základě řešení projektů specifického výzkumu: „Palba se současným dopadem střel u dělostřelectva AČR." Poskytovatel: Ministerstvo školství, mládeže a tělovýchovy. Kód projektu: SV20_FVL-K107-ŠUS. PRJ: 907010030271.

\section{SEZNAM ZKRATEK}

$\begin{array}{ll}\text { AČR } & \begin{array}{l}\text { Armáda České republiky } \\ \text { JFS }\end{array} \\ \text { Moint Fires Support (Společná palebná podpora) } & \begin{array}{l}\text { Multiple Round Simultaneous Impact (Pal- } \\ \text { ba se současným dopadem střel) } \\ \text { MRTOT }\end{array} \\ \text { TOT } & \text { Multiple Round Time On Target (Více střel „,čas na cíl“) } \\ \text { VeV-VA } & \text { Time On Target („„čas na cíl“) }\end{array}$

Autoři: $\quad$ Mjr. Ing. Michal ŠUSTR, nar. 1979, absolvent Fakulty ekonomiky a managementu Univerzity obrany v Brně. V letech $2001-2019$ působil na velitelských pozicích u dělostreleckých jednotek v rámci dělostřeleckého pluku v Jincích a na Úseky prípravy dělostřelectva v rámci Velitelství výcviku - Vojenské akademii ve Vyškově. $V$ současné době je odborným asistentem katedry palebné podpory Univerzity obrany. Zabývá se problematikou bojového použití dělostřelectva.

Prof. Ing. Ladislav Potužák, CSc. (plk. v zál.), nar. 1949, v roce 1971 absolvoval Vyšší dělostřelecké učiliště v Martině, v roce 1975 VA v Brně, obor velitelsko-štábni raketového vojska a dělostřelectva. Püsobil ve funkcích náčelník průzkumu oddilu, ZNŠ výcvikového a zabezpečovacího pluku a na cvičeních u vojsk zástupce velitele dělostreleckého pluku. Od r. 1977 působil jako pedagog a vykonával funkce náčelníka skupiny, zástupce vedoucího katedry a proděkana. V roce 1985 obhájil kandidátskou dizertačni práci, v roce 1992 habilitační práci a v roce 1999 byl jmenován profesorem. $V$ současné době 
působí na Katedře palebné podpory Fakulty vojenského leadershipu Univerzity obrany. $V$ pedagogické a vědecké činnosti se zaměřuje na problematiku sil bojové podpory se zaměrením na dělostřelectvo.

Pplk. Ing. Mgr. Martin BLAHA, Ph.D., nar. 1983, absolvent Univerzity obrany v Brně, Fakulty ekonomiky a managementu, obor Vojenský management. Pưsobil ve velitelských a štábních funkcích u dělostřeleckého oddilu. Od roku 2008 se podilí na pedagogické a vědecké činnosti Katedry palebné podpory na Univerzitě obrany v Brně. $V$ roce 2012 absolvoval doktorandské studium na Univerzitě obrany, ve studijním programu Ekonomika a management. $V$ současné době je pověřeným vedoucím Katedry palebné podpory Univerzity obrany. Zabývá se problematikou použití dělostrelectva, zejména oblastí rízeni palby a automatizaci procesů rízení palby.

Kpt. Ing. Jan IVAN, Ph.D., nar. 1988, absolvent Fakulty ekonomiky a managementu Univerzity obrany Brno (obor vojenský management). $V$ letech 2012 - 2016 působil na velitelských pozicích u průzkumných dělostřeleckých jednotek $v$ rámci dělostřeleckého pluku v Jincích. $v$ současné době odborným asistentem katedry palebné podpory Univerzity obrany. Zabývá se problematikou bojového použití dělostřelectva, zejména oblastí vyžadování a koordinace palebné podpory.

Jak citovat: ŠUSTR, Michal, Ladislav POTUŽÁK, Martin BLAHA a Jan IVAN. Střelba s jednotným dopadem střel a možnosti využití v Armádě České republiky. Vojenské rozhledy. 2020, 29 (4), 084-093. ISSN 1210-3292 (print), 2336-2995 (on-line). Available at: www.vojenskerozhledy.cz. 


\title{
Informační systém tělesné přípravy Armády České republiky
}

\section{Physical Training Information System of the Armed Forces of the Czech Republic}

\author{
Petr Hanák, Jiří Sekanina, Tomáš Ráčil
}

Abstrakt: Článek řeší současný stav evidence a vyhodnocování tělesné prípravy vojáků Armády České republiky. Nese v sobě analytickou i návrhovou část. $V$ analytické části jsou diskutovány klady a zápory současné evidence dat tělesné prípravy a identifikovány hlavní nedostatky a problémy. $\checkmark$ článku je navržena optimalizace současného stavu prostřednictvím pokročilého informačního systému, který by pokrýval současné potřeby tělovýchovných pracovníků $a$ je za tímto účelem v současné době tvořen $\checkmark$ prostředí Univerzity obrany $v$ Brně. $v$ článku je nastíněno možné praktické využití informačního systému v armádní praxi.

Abstract: The article addresses the current state of registration and evaluation of physical training of soldiers of the Army of the Czech Republic. It includes analytical and design part. The analytical part discusses the pros and cons of current evidence of physical training data and identifies the main shortcomings and problems. The article proposes the optimization of the current state through an advanced information system that would cover the current needs of physical education workers and for this purpose is currently created in the environment of the University of Defense in Brno. The article outlines the possible practical use of the information system in military practice.

Klíčová slova: Informační systém; tělesná zdatnost; tělesná výkonnost; tělesná príprava; voják.

Key words: Information systém; Physical Fitness; Physical Performance; Physical Training; Soldier. 


\section{ÚVOD}

Uplatnění moderních informačních systémů (IS) je vzhledem k jejich vyspělosti využitelné takřka ve všech armádních oblastech. Významnou armádní oblastí je tělovýchova, se kterou se v průběhu své kariéry setkává každý voják. Vojáci jsou povinni prokazovat svoji tělesnou výkonnost v rámci výročního a profesního přezkoušení. Testování, následná evidence jednotlivých výkonů společně s vyhodnocováním klade na tělovýchovné (TV) pracovníky zvýšenou administrativní zátěž. Zároveň v oblasti tělovýchovy vyvstávají nové problémy, na které je nutné reagovat a připravit optimální způsoby řešení. Příkladem současného problému je fakt, že každoročně přibývá množství vojáků, kteří nemohou fyzické testy ze zdravotních důvodů vykonávat a vyžadují specifický přístup k udržení jejich tělesné zdatnosti. Armádní tělovýchova potřebuje na vývojové tendence a změny pružně reagovat. IS by mnohých ohledech představoval ideální nástroj, který by trendy v tělovýchově identifikoval a práci tělovýchovných pracovníků zefektivnil.

V armádě však nebyl doposud žádný IS zaveden. V AČR je využíván zastaralý způsob evidence dat, který neodpovídá současným požadavkům a nezohledňuje žádané potřeby. AČR přichází o možnost komplexního a systematického monitoringu tělesné výkonnosti svých vojáků a jednotek.

Moderní pojetí správy dat s výkony vojáků ve vojenské tělovýchově je v porovnání s aktuálním stavem rozdílné především v tom, že soudobé IS dokáží po celou dobu služebního poměru vojáka uchovávat a vyhodnocovat široké portfolio dat. Na základě výsledků je možné vyvodit negativní vývojové trendy a za pomoci vhodně implementovaných opatření efektivně reagovat na dosažení žádoucího stavu, a to jak u jednotlivce, tak i u jednotek, potažmo celé AČR. Z tohoto pohledu je zřejmé, že si vojenská tělovýchova žádá zavedení výkonného IS, který by tělovýchovným pracovníkům práci s daty uživatelsky zjednodušil a přitom dokázal generovat výsledky využitelné pro potřeby organizace i samotných vojáků. Článek předkládá a navrhuje optimalizaci současného stavu monitoringu tělesné výkonnosti vojáků za pomoci moderního IS.

\section{EVIDENCE DAT Z TĚLESNÉ PŘíPRAVY V PROSTŘEDí AČR}

Problém evidence dat $z$ tělesné výkonnosti je v menším nebo větším rozsahu patrný $u$ všech vojenských zařízení a útvarů AČR. Významnost tohoto problému je tím palčivější, čím více vojáků jednotka má. Univerzita obrany (UO) v Brně v tomto článku slouží jako modelové pracoviště, na kterém bude prakticky demonstrována implementace nových navrhovaných opatření v systému evidence fyzických výkonů studentů i vojáků z povolání. Důvody, proč se zabývat evidencí dat:

1. Centrum tělesné výchovy a sportu (CTVS) UO řeší komplexně tělesnou přípravu vojáků z povolání (VZP) UO, tzv. stálého stavu a studentů UO, kteří jsou rovněž 
zařazení do kategorie VZP, ale tělesná př́prava je u nich prováděna s jistými specifiky ${ }^{1}$. Obě skupiny představují co do počtu stovky vojáků, kteří v průběhu výcvikového roku vygenerují tisíce dat.

2. $V$ tak velkém souboru je i poměrně vysoký počet vojáků, kteří mají s plněním zadaných požadavků z tělesné přípravy problémy. Tělovýchovní pracovníci se aktivně podílejí na řízení zaměstnání $v$ tělesné př́ípravě, nicméně bez detailnějších podkladů o výkonnosti jedince nebo jednotky je působení plošné a nemusí vždy plně zohledňovat skutečné individuální potřeby výkonnostně slabších vojáků.

3. Dalším faktorem, který ztěžuje průběh tělesné přípravy u jednotek, je poměrně početně hojně zastoupená skupina vojáků se zdravotním oslabením, tedy těch, kteří podle NVMO č. 12/2011 nemohou být z objektivních zdravotních důvodů podrobeni kontrolním testům z výročního a profesního přezkoušení. To však neznamená, že by tito vojáci neměli dbát o udržení nebo rozvoj své tělesné výkonnosti. Právě u této skupiny je stěžejní, aby vhodně vybranými cviky (na základě konzultace lékaře a TV pracovníka) rozvijeli žádané pohybové schopnosti v rámci svých pohybových a zdravotních možností.

4. Benefitem evidence testování tělesné zdatnosti je vytvoření uceleného přehledu o tělesné výkonnosti vojáků, a to např́íc celou armádou. Na základě dosažených výsledků testů identifikovat slabiny a na jejich odstranění v dalších období intenzivně pracovat. Pokud bude analyzováno, že např. při plnění disciplíny hodu granátem má konkrétní jednotka problém s plněním limitů, a v jiných disciplínách nezaostává, je možné více času dedikovat nácviku techniky hodu.

5. IS by přispěl i cílenějšímu směřování tělovýchovných programů TV pracovníky $\checkmark$ rámci preventivních rehabilitací vojáků $z$ povolání. $V$ př́padě existence IS by měl ř́ící TV pracovník možnost nahlédnout do záznamu vojáků, kteří mají zájem zlepšit svou výkonnost. Následná tvorba tréninkových programů by byla utvářena na aktuální potřeby a trénink by byl pravděpodobně efektivnější.

V současné době se v podmínkách AČR (včetně UO) k shromažd'ování a vyhodnocování dat tělesné výkonnosti vojáků z povolání využívá elektronická databáze vytvořená v programu Excel. Vzhledem $k$ době jejího vzniku (na přelomu milénia) ji již nelze objektivně považovat za adekvátní a současným potřebám AČR dostatečně vyhovující nástroj pro dlouhodobé a detailnější sledování tělesné výkonnosti vojáků z povolání. Doba pokročila natolik, že je možné databázi nahradit IS, který umožní zpracování dat na nesrovnatelně vyšší úrovni. Přidanou hodnotou dnešní doby je i finanční dostupnost IS. Výkonné IS se dají aktuálně pořídit v jednotkách tisíců, nebo jsou na internetu ke stažení zcela zdarma.

1 Dle NVMO č. 12/2011, Čl. 104. 


\section{ANALÝZA SOUČASNÉHO SOFTWARE VÝROČNÍHO PŘEZKOUŠENÍ VOJÁKŮ Z POVOLÁNÍ}

Na obrázku 1 je zobrazen v AČR aktuálně využívaný program Excel, který je uzpůsoben na vyhodnocování pouze jedné funkcionality, a tou je přezkoušení z fyzické zdatnosti vojáků z povolání (VZP). Práce s ním je poměrně jednoduchá a v době svého vzniku byl program považován za průlomový produkt výrazně usnadňující práci TV pracovníkům v oblasti evidence dat a vyhodnocování.

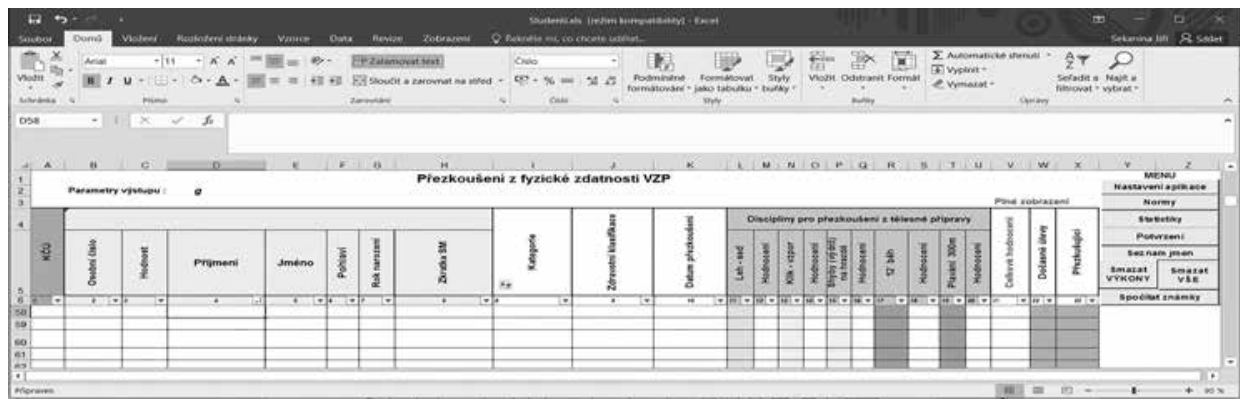

Obrázek č. 1: Vyhodnocovací program výročního přezkoušení AČR

Zdroj: Program pro vyhodnocování výročního přezkoušení

Pozitiva programu:

- Jednoduchá obsluha;

- umožňuje transport jmenného souboru VZP pro hodnocený rok z personální databáze;

- součástí programu jsou normy výročního přezkoušení, které po nastavení aplikace automaticky aktualizují věkové kategorie přezkoušených VZP $\mathrm{k}$ danému roku přezkoušení;

- umožňuje statistické vyhodnocení uživatelem v zadaném rozsahu;

- umožňuje tisknout potvrzení pro služební hodnocení.

Negativa programu:

- Program je určen výhradně pro Výroční přezkoušení VZP, není možné zaznamenávat výkony z Profesního přezkoušení;

- v průběhu vkládání dat do programu Ize snadno omylem soubor poškodit a způsobit nesprávnou funkčnost programu;

- v případě obsáhlejších souborů si zpracování žádá čas a vyhodnocování je časově náročnější;

- statistická vyhodnocení Ize provádět pouze za jeden kalendářní rok;

- tisk potvrzení o absolvování výročního přezkoušení lze provádět pouze po jednotlivých vojácích. $V$ prípadě, že je potřeba tisknout např. 100 a více potvrzení, je potřeba počítat s velkou časovou náročností. 
Slabinou současného monitoringu tělesné výkonnosti vojáků je to, že není možné sledovat výkonnost vojáků v delším časovém horizontu. Pokud TV pracovník potřebuje získat dosažené hodnoty konkrétního vojáka v delším časovém rozpětí, musí pracovat se staršími soubory. V případě většího celku, čítajícího např. stovky vojáků, je pak pro TV pracovníka poměrně komplikované získávat detailní přehled o výkonnosti vojáků.

\section{ANALÝZA SOUČASNÉHO STAVU EVIDENCE TĚLESNÉ VÝKONNOSTI U STUDENTU゚ UO}

Tělesná príprava studentů vojenských škol a posluchačů kariérových kurzů se uskutečňuje ve vyučovacím predmětu „Tělesná výchova", popř. "Tělesná príprava" podle učební dokumentace vojenské školy, popř. kurzu, s respektováním požadavků vyplývajících z profilu absolventů podle čl. 9 odst. 3. To s sebou nese řadu požadavků na dosažení poměrně vysoké úrovně PS a PD, ke které se studenti musí propracovat. ${ }^{2}$

Výkonnost studentů je pečlivě zaznamenávána od okamžiku přijímacího řízení, kdy jsou od studentů prostřednictvím silového a vytrvalostního testu získána první data. $\checkmark$ průběhu studia studenti následně plní zadané požadavky vyplývající z tématiky bloku předmětu TV v daném semestru, včetně stanovených zápočtových požadavků. Při tvorbě Studijních programů SP 19 bylo zohledněno, aby studenti po celou dobu studia v každém letním semestru absolvovali identické standardizované testy ze silových a vytrvalostních schopností, které po následném vyhodnocení umožní identifikovat a kategorizovat studenty podle jejich výkonnosti. CTVS pracuje pouze se souborem zpracovaným v programu Excel (obr. 2) pracovníky CTVS, který trpí stejnými slabinami jako jeho propracovanější „starší bratr“ využívaný pro vyhodnocování výročního přezkoušení.

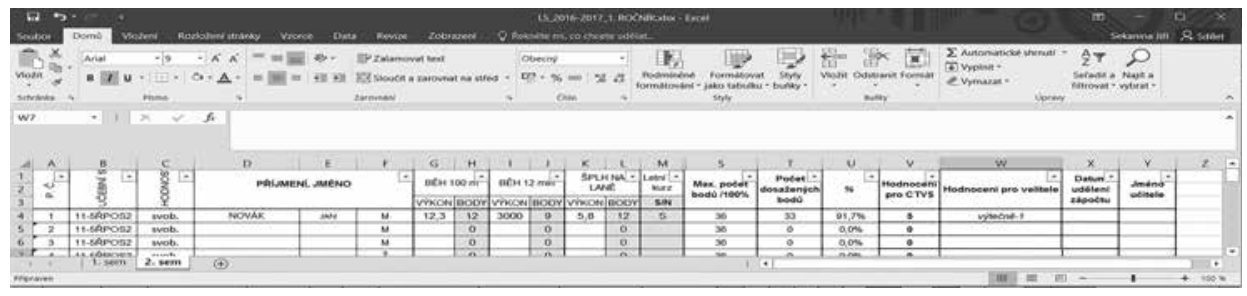

Obrázek č. 2: Vyhodnocovací program CTVS UO.

Dalším signifikantním šetřením, které podstupují všichni studenti UO je antropometricko-fyziologické vyšetření, které obvykle probíhá v letním období na UO za přispění

2 Normativní výnos Ministerstva obrany číslo 12, ze dne 15. března 2011. Služební tělesná výchova v rezortu Ministerstva obrany. MO, Tychonova 1. Praha. 2011. 
odborné pomoci Vědeckého a servisního pracoviště - CASRI Praha. Toto vyšetření detailně „dokresluje“ tělesnou výkonnost studentů a vytvárí poměrně podrobný přehled o každém studentovi. Ten pak $v$ prrípadě potřeby slouží jako stěžejní materiál pro individuální práci, především s méně zdatnými studenty.

Vzhledem k vysokému počtu studentů a širokému spektru požadavků není možné organizačně zabezpečit, aby jedna učební skupina měla po celou dobu studia jednoho učitele. $V$ takovém případě je žádoucí, aby učitel TV měl přehled o historii svých studentů a věděl o problémech, které jednotlivce nebo i skupinu provází.

Dalším faktorem, který se nevyhýbá ani studentům UO, je dočasné zdravotní oslabení. Důslednou evidencí o opatřeních, které byly studentu zadány, by byl získán podklad pro implementaci vhodných cvičení a to i z dlouhodobého hlediska.

Mezi studenty UO jsou i výkonnostní sportovci, kteří reprezentují armádu v rámci soutěží AČR, ale i mimo ní. Záznamy o studentech - výkonnostních sportovcích a jejich výkonech jsou pracovníky CTVS vedeny ve zvláštní databázi. Přínosné by bylo, aby záznamy byly $v$ jednom IS a komplexní výsledky všech typů měření byly využitelné jak pro další vědecká zpracovávání, tak především pro studenty - klienty.

Aktuálně není k dispozici žádný elektronický nástroj, který by statisticky vyhodnotil, jaká je výkonnostní úroveň studentů (učebních skupin) ve vztahu ke konkrétnímu učiteli, který skupinu vyučoval. Tahle možnost by se jevila jako poměrně zajímavý nástroj pro hodnocení kvality výuky, jak ze strany učitel - žák, tak žák - učitel.

\section{NAVRHOVANÝ INFORMAČNÍ SYSTÉM TĚLESNÉ PŘíPRAVY AČR}

Každý IS se skládá ze tři hlavních částí, které jsou hardware, software a lidé. Je nutné zajistit správnou funkci jednotlivých prvků, ale také jejich interoperabilitu. Pokud má být dosaženo kvalitních výsledků je nezbytné pracovat v souladu s těmito principy a s ohledem na jedinečnou povahu armádního prostředí, konkrétněji pak vojenské tělovýchovy. $V$ následujících odstavcích bude pojednáno o úskalích spojených s implementací nového IS.

V oblasti hardwaru je značnou výhodou existence stávající infrastruktury, a to především bezpečných datových sítí, využitelných v prípadě lokální, nebo globální implementace. $V$ rámci armády také existují servery schopné zajišt́ovat provoz IS, a to včetně prostoru pro ukládání dat, ale to platí spíše v případě globálního nasazení. V príipadě lokálního řešení tato možnost nemusí existovat v závislosti na situaci jednotlivých lokalit. Řešením by byl nákup lokálního serveru, který by splňoval typické standardy. Těmito standardy je myšlena redundance klíčových komponentů (úložiště, napájení, výpočetní jednotka) a zajištění stabilního napájení (přepětová ochrana a záložní napájení). Pokud by byl v konkrétní lokaci zvýšený požadavek na analýzu dat, je možné do serveru přidat i grafickou výpočetní jednotku, která je schopná tento proces značně urychlit. Konkrétní specifika těchto systémů a případná potřeba doplnění (například sítovými a fyzickými bezpečnostními prvky) je závislá na konkrétním místě a rozsahu implementace.

Systém by byl vyvíjen od prvního okamžiku s ohledem na aktuální lidské zdroje, které jsou k dispozici v rámci pracovišt' zajištujících vojenskou tělovýchovu. Tím bude 
zajištěna minimální potřeba přeškolování současných zaměstnanců, nebo vytváření nových pracovních pozic. Konkrétní uživatel v systému by měl přidělenou funkci podle role, kterou by zastával. Takto by byly eliminovány př́padné škody způsobené špatným použitím softwaru. Omezení funkcí pro konkrétního uživatele by mělo za následek větší přímočarost systému jako takového a s tím související zjednodušení zaškolování uživatelů. Každá role by pak měla vlastní dokumentaci, která by byla dostupná prímo v aplikaci a popisovala by dostupné funkce a jejich správné použití. Pokud jde o zabezpečení chodu hardwaru, bylo by možné využít existující lidské zdroje, které se starají o jinou výpočetní techniku lokalizovanou na pracovištích, nebo využít smluvní stranu zabezpečující konkrétní hardware. Softwarová podpora by vzhledem k plánu na vytvoření tohoto systému $\checkmark$ rámci $\cup O$ musela být řešena $v$ závislosti na rozsahu implementace systému do armády. Pokud by bylo v použití jen lokální řešení v rámci univerzity, je možné řešit vzniklé problémy a požadavky ve spolupráci s odborníky a studenty na UO. Ovšem implementace na více lokalitách by nejspíše vyžadovala vytvoření specializované skupiny.

Na českém nebo i zahraničním trhu v současné době neexistuje softwarové řešení, pokrývající potřeby vyplívající z jedinečné povahy vojenské tělovýchovy. Řešením by bylo nechat systém vybudovat od základu, ale jak již bylo zmíněno dříve, aktuálním zámyslem je vytvořit experimentální sytém v rámci univerzity. Tento způsob sebou přináší značné výhody, ale i určité nevýhody.

Jednou z výhod systému vytvořeného v rámci univerzity je přirozeně blízká spolupráce mezi klientem a dodavatelem systému. Znalost prostředí a do určité míry i potřeb spojených s danou problematikou může do značné míry zmírnit počet iterací, kterými by projekt musel projít. Další výhodou by byla cena. Většina nástrojů a softwaru potřebných pro vývoj je volně dostupná, nebo je již ve vlastnictví AČR. Zapojení studentů UO do vývoje by mělo dvojí efekt. Snížení ceny vývoje systému a vytvoření př́ležitostí pro studenty v oblasti praktické vědecké činnosti, nebo závěrečných prací. Tímto způsobem by mohla být řešena i dlouhodobá podpora systému, kdy by studenti mohli vyvíjet nové moduly, nebo řešit problémy systému. Nevýhodou tohoto př́stupu je samozřejmě nezkušenost v oblasti vývoje informačních systémů a potenciální problematika podpory při celoarmádním zavedení systému.

Konkrétní softwarové řešení by se skládalo z několika prvků: databázového systému, API a webového rozhraní.

1. Databázového systému, který slouží pro skladování a třídění dat. Dále by bylo možné šifrovat nezbytná osobní data. Jednodušší analýzy by mohly být také prováděny přímo na úrovni databáze. Ve spolupráci s API by bylo zajištěno permanentní zaznamenávání všech změn a ochrana před neoprávněnou manipulací. Zaznamenávání všech změn by mělo také za následek možnost obnovení konkrétních změn. Oproti aktuálnímu řešení by bylo docíleno značného zvýšení bezpečnosti a vzhledem k mnohem lepší schopnosti databáze skladovat a třídit data i rychlejšího fungování. Pro lepší představu o struktuře databáze byl vytvořen diagram zachycující jednotlivé entity systému a jejich vzájemné interakce (obr. 3). 


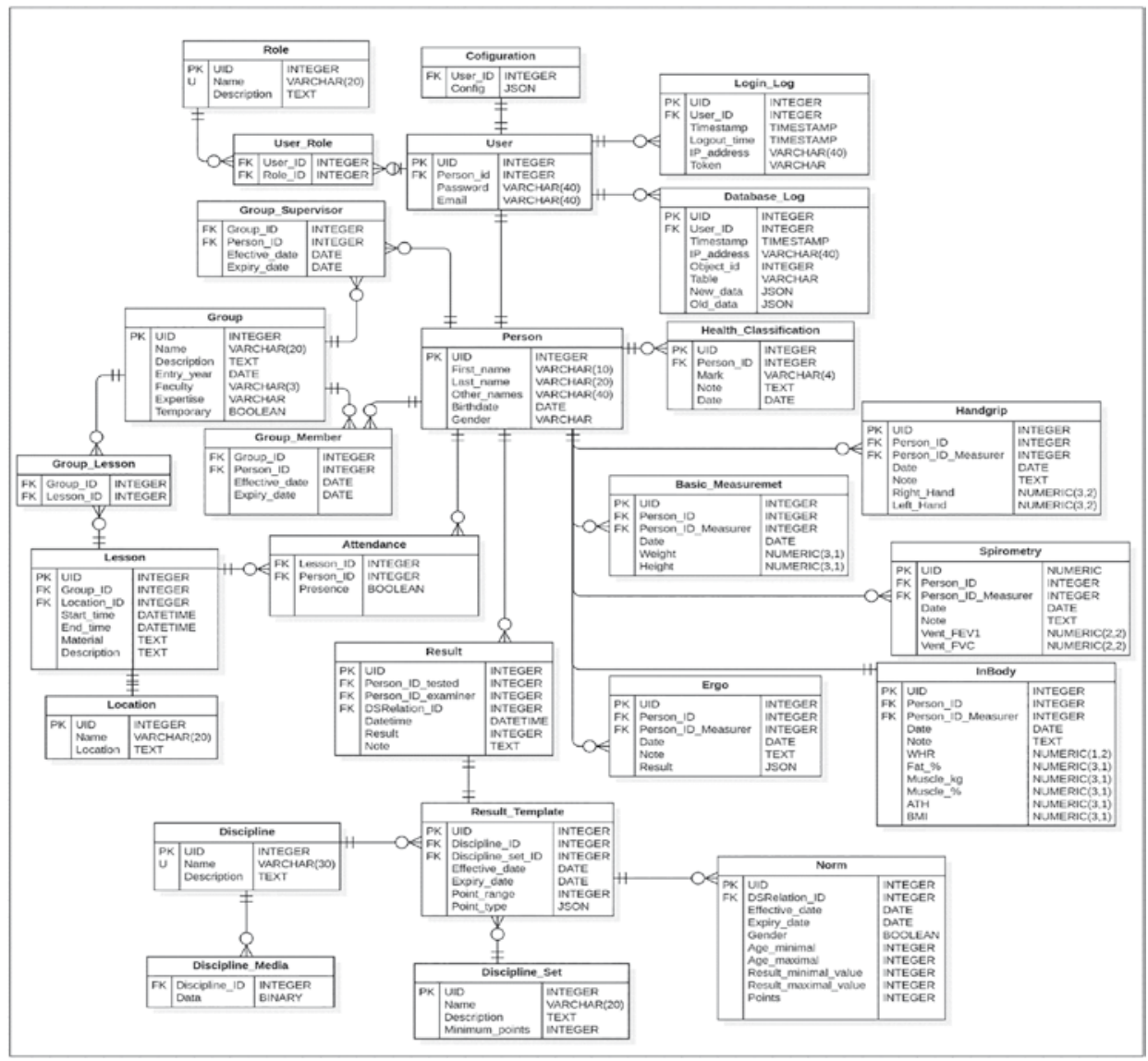

Obrázek č. 3: Databázová struktura

2. API (Application Programming Interface), které je řídícím prvkem a funguje jako prostředník mezi databází a webovým rozhraním. Staralo by se o identifikaci a přirazení práv uživateli. Dále by poskytovalo analytické funkce a obsluhovalo výpočty, které by nemohly být řešeny na úrovni databáze. Také by zde byla řešena konverze dat, která je nezbytná u některých prvků systému (například InBody, nebo W170). Vzhledem k univerzálnímu způsobu, jakým API komunikují, by bylo možné systém jednoduše rozšírit o další moduly.

3. Webové rozhraní, poskytující informace z API uživateli ve srozumitelné v podobě. Jedná se vlastně o normální webovou stránku, ke které je uživatel schopný přistupovat z jakéhokoliv systému, který má webový prohlížeč. Podobně jako API i webové rozhraní by poskytovalo jen služby, které uživatel může používat. To by mělo za následek zjednodušení systému, ale ne na úkor funkcí. Konkrétní vzhled a funkčnost této části však záleží hlavně na budoucích uživatelích. 
Webové rozhraní, ale nemusí být jediným rozhraním pomocí, kterého by uživatel mohl komunikovat $s$ informačním systémem. Vzhledem ke způsobu, jakým API komunikují, je možné vytvořit doplňující mobilní aplikaci pro všechny platformy s částečnou, nebo i úplnou funkčností webového rozhraní. Pro lepší pochopení struktury systému byl vytvořen diagram nasazení (obr. 4), který zachycuje možné hardwarové a softwarové prvky nového IS.

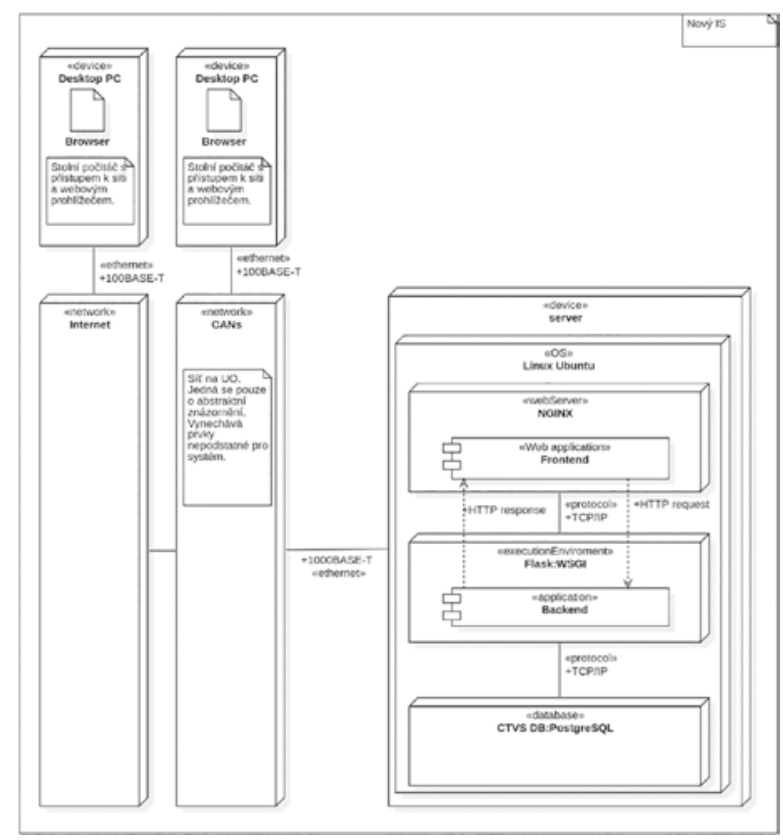

Obrázek č. 4: Diagram nasazení 
Pokud by byl systém správně implementován, jednalo by se o jedinečnou platformu, která by sjednotila všechny způsoby měření tělesné výkonosti pod jednu platformu. Systém by byl vytvořen s ohledem na jeho uživatele a jejich potřeby, tedy měl by být uživatelsky přivětivý a přitom komplexní. $V$ rámci této platformy by bylo integrováno veškeré sledování zdravotního stavu, výsledky výročních i profesních přezkoušení, fyziologicko-antropometrická data, výkonnostní data. $V$ neposlední řadě pak disciplíny specifické pro konkrétní vojenské útvary a zařízení, jakými jsou např́klad zápočtové disciplíny na Univerzitě obrany. Takový soubor dat by umožnil úplně nový rozsah analýzy, nebot' by sledovala celou kariéru vojáka ve všech aspektech ovlivňující tělesnou výkonost, ale také trendy v rámci větších celků, nebo změny ve způsobu jakým je k vojenské tělovýchově přistupováno a mnoho dalšího. Také by bylo možné skrze tuto platformu zjednodušit předávání informací mezi tělovýchovnými pracovníky a jejich svěřenci, at' už se jedná o sledování osobního růstu, nebo plánování tréninků. Vhledem k množství dat, která by byla takto sbíraná a vytvářená, se také nabízí implementace strojového učení pro další analýzu dat a zvýšení efektivity celého systému.

\section{ZÁVĚR}

Tělesná příprava je nezastupitelným atributem v systému profesionální prípravy každého vojáka a z tohoto úhlu pohledu je přirozené, že si žádá patřičnou pozornost. Významnost tělesné př́pravy podtrhuje i fakt, že se tělesná zdatnost mladé populace stále zhoršuje a tento problém aktuálně prostupuje do všech oblastí naší společnosti, včetně vojenství. Armáda se dílčími opatřeními snaží na tento fenomén reagovat a v rámci současných možností nedostatky $v$ tělesné výkonnosti vojáků eliminovat. Pro zásadní systémová rozhodnutí je však nezbytné disponovat širokou škálou různých dat. Na základě jejich detailních analýz je pak možné poměrně přesně predikovat budoucí trendy a včas implementovat taková účinná opatření, která negativní tendence budou potlačovat. Článek na základě analýz předkládá reálný obraz aktuální situace a odhaluje podceňování v evidenci a vyhodnocování získaných dat.

V článku je navrženo, jakým směrem je možné se ubírat v oblasti sběru dat a jak současný stav optimalizovat. Navrhovaný IS by podstatným způsobem rozšíril portfolio sledovaných parametrů tělesné výkonnosti vojáků a umožnil by poměrně detailní predikci trendů tělesné výkonnosti vojáků. UO se jeví jako ideální prostředí pro experimentální ověření funkčnosti a opodstatněnosti IS. Studenti UO jsou pravidelně, dlouhodobě a komplexně prověřováni z mnoha disciplín a navíc jsou sledovány jejich antropologicko-fyziologické parametry. IS má v sobě zakomponované i části, které zohledňují zdravotní indispozice vojáků a opatření pro zlepšení, která jim byla zadána. Díky své modularitě není jeho funkčnost omezena, ale může se vyvíjet a reagovat tak nové potřeby armády. Svým pojetím se jedná o mimořádný a jedinečný projekt, který zatím nebyl zaveden v žádné armádě. Pozitivní dopad IS Ize spatřovat jak v praktické, tak i teoretické rovině. Samozřejmým předpokladem pro práci s IS je fakt, že ctí GDPR. 
Autoři: $\quad$ Plk. Mgr. Petr Hanák, narozen v roce 1964. Je absolventem Vojenského oboru Fakulty tělesné výchovy a sportu Univerzity Karlovy (1988). Působil na různých funkcích $v$ oblasti vojenské tělovýchovy $v$ rámci AČR. $V$ současné době působí ve funkci ředitele Centra tělesné výchovy a sportu Univerzity obrany v Brně. Dlouhodobě se zabývá problematikou fyzické zdatnosti $v$ rámci doplňování personálu pro potřeby ozbrojených sil, problematikou tělesné výchovy $v$ systému vzdělávání a problematikou pohybových aktivit jako součásti životního stylu.

Pplk. gšt. PhDr. Jiří Sekanina, Ph.D., narozen v roce 1973. V roce 1997 ukončil studium na VO FTVS UK v Praze. V roce 2002 získal titul PhDr., v roce 2016 titul Ph.D. na Univerzitě obrany v Brně ve studijním programu ekonomika a management. Od roku 1999 pracuje jako akademický pracovník. V současné době zastává funkci zástupce ředitele CTVS UO. V průběhu vojenské kariéry působil jako vojenský pozorovatel v rámci několika misí OSN. Dlouhodobě se věnuje problematice tělesné prípravy studentů UO a optimalizačním procesům v tělesné výchově na vojenské vysoké škole.

Por. Ing. Tomás Ráčil, narozen v roce 1996. Je absolventem Univerzity obrany $v$ Brně v oboru komunikační a informační systémy. $V$ současné době pracuje jako pedagogický pracovník Univerzity obrany. Jeho oblastí zájmu jsou informačni systémy a jejich implementace do vojenského prostředí.

Jak citovat: HANÁK, Petr, Jiří SEKANINA a Tomáš RÁČIL. Informační systém tělesné př́pravy Armády České republiky. Vojenské rozhledy. 2020, 29 (4), 094-104. ISSN 1210-3292 (print), 2336-2995 (on-line). Available at: www.vojenskerozhledy.cz. 


\section{Společná bezpečnostní a obranná politika EU v kostce - část druhá}

\section{EU's Common Security and Defence Policy in a Nutshell - Part Two}

\section{Vilém Kolín}

Abstrakt: Společná bezpečnostní a obranná politika (CSDP), na jejímž základě EU buduje svoji obrannou identitu, je širokospektrální. Zaměřuje se nejen na obrannou složku CSDP, ale i na související oblasti jako obranný průmysl a trh, obranný výzkum a vývoj, a s tím korespondující legislativu a různé politické a finanční nástroje na jejich podporu. To na straně jedné brání snadnému ohraničení problematiky evropské obrany. Na straně druhé to odráží robustnost př́stupu EU k evropské obraně a ochotu mobilizovat všechny dostupné zdroje. Článek přibližuje genezi evropské obrany, jejich hlavních milníků, aktérů, souvisejících procesů, pravidel, a klíčových nástrojů, které jsou dnes z podstatné části soustředěny pod hlavičkou CSDP. Aktuální otázky evropské obrany včetně scénářů jejího možného budoucího vývoje mají v textu také své místo, stejně jako přispěvek České republiky.

Abstract: The Common Security and Defence Policy (CSDP), on the basis of which the EU builds its defence identity, has a broad spectrum. It focuses not only on the defence component of the CSDP, but also on associated areas such as defence industry and market, defence research and development, and supports them with related legislation and various policy and financial instruments. On the one hand, this prevents the issue of European defence from being easily confined. On the other hand, this reflects the robustness of the EU's approach to European defence and its willingness to mobilize all available resources. The article describes the evolution of European defence, its major milestones and actors, related processes and rules, and the key tools that are now largely concentrated under the umbrella of the CSDP. Current issues of European defence, including scenarios of its possible future development, are also addressed, as well as the contribution of the Czech Republic.

Klíčová slova: EU; SBOP; PESCO; EDA; Lisabonská smlouva; obranná politika; obranný průmysl.

Key words: $\quad$ EU; CSDP; PESCO; EDA; Lisbon Treaty; Defence Policy; Defence Industry. 


\section{JAKÉ JSOU HLAVNÍ SOUČASNÉ AGENDY EVROPSKÉ OBRANY? 1}

\subsection{Stálá strukturovaná spolupráce}

Vznik PESCO v roce 2017 je vedle Koordinovaného ročního přezkumu v oblasti obrany (Coordinated Annual Review on Defence - CARD) a EDF, které jsou bliže popsány níže, jednou ze tři nejdůležitějších evropských iniciativ v oblasti obrany posledních let. PESCO vychází z Lisabonské smlouvy a účastní se ho s výjimkou Velké Británie, Dánska a Malty všechny členské státy EU, které se tím zavázaly mít vyšší ambice a naplňovat přísnější závazky s cílem společně vyvinout nové obranné schopnosti a dát je $k$ dispozici pro operace a mise EU. ${ }^{2}$ Snaha o vybudování efektivní evropské kapacity k ochraně před vnějšími hrozbami je akcentovaná již v EUGS a vychází z poznání, že měkká síla (Soft Power) EU nemá důvěryhodnost, pokud není v př́padě nutnosti podpořena tvrdou silou (Hard Power). ${ }^{3}$ Tehdejší předseda Evropské komise Juncker, který se výrazně zasloužil o znovuoživení myšlenky vytvoření $\mathrm{PESCO}, \mathrm{k}$ tomu ve svém projevu o stavu Unie v roce 2016 poznamenal, že je třeba vytvořit Evropu, která přijímá odpovědnost, ochraňuje, a brání doma i v zahraničí. ${ }^{4}$

Rozdíl mezi PESCO a ostatními evropskými formami spolupráce v oblasti obrany je v tom, že závazky v rámci PESCO jsou právně závazné. V současnosti existuje 20 závazků, které vedle specifických požadavků na zvyšování obranných schopností a účasti v operacích zahrnují i požadavky rozpočtové, investiční, obranně-plánovací, akviziční a průmyslové. ${ }^{5}$ Jejich plnění spolu s plněním specifických cílů, které byly stanoveny pro každou fázi implementace PESCO (prozatím ve dvou fázích: 2018-2020 a 2021-2025), je každoročně monitorováno ve formě Národních implementačních plánů (National Implementation Plans - NIPS). Členské státy své NIPs každoročně aktualizují a jejich konečnou podobu zasílají k posouzení (assessment) sekretariátu PESCO, který tvoří EDA, EUMS a EEAS. ${ }^{6}$ Po obdržení všech NIPs pak sekretariát PESCO vypracuje hodnotící zprávy za každý členský stát i celkovou hodnotící zprávu za PESCO jako celek. Ta pak slouží za základ výroční

1 Názory a doporučení obsažené v tomto článku jsou výlučně autora.

2 Obranná spolupráce: 23 členských států podepsalo společné oznámení o stálé strukturované spolupráci (PESCO), Rada EU, Tisková zpráva, 13. listopadu 2017 [online]. [cit. 31. 8. 2019]. Dostupné z https://www.consilium.europa.eu/cs/press/press-releases/2017/11/13/ defence-cooperation-23-member-states-sign-joint-notification-on-pesco/.

3 KOLÍN, Vilém, Stálá strukturovaná spolupráce (PESCO): nový piliř v budování evropské obrany. Vojenské rozhledy. 2018; 27(4), S. 21-22. ISSN 1210-3292.

4 JUNCKER, Jean-Claude. Projev o stavu Unie 2016. Lucemburk: Úřad pro publikace Evropské unie, 2016. S 9. ISBN 978-92-79-61959-5. Dostupné z https://op.europa.eu/en/publication-detail/-/ publication/c9ff4ff6-9a81-11e6-9bca-01aa75ed71a1/language-cs.

Ref. 3. S. 24-27.

Ibid. S. 29. 
zprávy Vysokého představitele o implementaci PESCO.7 Pokud se prokáže, že některý členský stát již nesplňuje stanovené závazky, může Rada přijmout rozhodnutí o pozastavení členství tohoto státu v PESCO. ${ }^{8}$

Součástí závazků PESCO je i účast v jednom z projektů PESCO, kterých je v současnosti dohromady 47 , rozdělených do sedmi skupin podle zaměření: pozemní, vzdušné, námořní, vesmír, kybernetický prostor, společné a podpůrné schopnosti, a výcvik a cvičení. ${ }^{9}$ Tyto projekty byly vybrány ve třech ročních vinách mezi roky 2018-2019 podle kritérii sestavených sekretariátem PESCO, jakými jsou příspěvek ke koherenci rozvoje schopností napříc EU, vyspělost projektu, koherence výstupů projektu s NATO, finanční a průmyslové zázemí projektu s možností spolufinancování z EDF, a příspěvek projektu k operačním potřebám EU, tzn. posílení disponibility, interoperability a schopnosti nasazení sil pro operace a mise CSDP. ${ }^{10}$ Schválené projekty jsou pak realizovány a financovány členskými státy, které jsou účastníky projektu v čele s koordinátorem, jenž má odpovědnost za projekt jako celek a každoročně informuje sekretariát PESCO o dosaženém pokroku. ${ }^{11}$ Ten je následně zahrnut podobně jako výše zmíněné hodnocení členských států v návaznosti na posouzení NIPs do výroční zprávy Vysokého představitele o implementaci PESCO. ${ }^{12}$ Koordinátor projektu má možnost požádat EDA o pomoc při realizaci projektu, což múže posléze vést $\mathrm{k}$ transformaci celého nebo části projektu v projekt EDA (jeden takový projekt už existuje a další jsou v prípravě). ${ }^{13}$

7 Ibid. S. 29-30.

8 Ibid. S. 30-31.

9 Aktuální seznam projektů PESCO včetně jejich popisu a zaměření je dostupný z https://pesco. europa.eu/.

10 Ref. 3. S. 31.

11 Rozhodnutí Rady (SZBP) 2018/909 ze dne 25. června 2018 o sestavení společného souboru pravidel řízení pro projekty stálé strukturované spolupráce, Úřední věstník Evropské unie, 26. června 2018 [online]. [cit. 31. 8. 2019]. Dostupné z https://eur-lex.europa.eu/eli/dec/2018/909/ oj.

12 Veřejná část zprávy z roku 2019: Council Recommendation assessing the progress made by the participating Member States to fulfil commitments undertaken in the framework of permanent structured cooperation (PESCO) (8795/19), Council of the European Union, Brusel, 6. května 2019 [online]. [cit. 31. 8. 2019]. Dostupné z https://data.consilium.europa.eu/doc/document/ ST-8795-2019-INIT/en/pdf.

13 Latest News: EDA to take forward PESCO project on CBRN surveillance, Brusel, 12. listopadu 2019 [online]. [cit. 16. 11. 2019]. Dostupné z https://www.eda.europa.eu/info-hub/press-centre/ latest-news/2019/11/12/eda-to-take-forward-pesco-project-on-cbrn-surveillance. 


\subsection{Koordinovaný roční přezkum v oblasti obrany}

Závazky PESCO obsahují mimo jiné i řadu referencí na CARD, který se má stát hlavním vodítkem pro identifikaci budoucích projektů včetně projektů PESCO. ${ }^{14}$ CARD, jež se po pilotní fázi rozběhl na konci roku 2019, bude každé dva roky mapovat národní situaci členských států a identifikovat možné oblasti spolupráce a projekty, jejichž výstupy by se ve formě nových technologií a zbraňových systémů měly stát základem pro přiští společné akvizice. V rámci pilotní fáze, která se uskutečnila v letech 2017-2018, se CARD soustředil na informace o národních výdajích na obranu a rozvoji schopností, které dále analyzoval ve třech oblastech: (i) obranné plánování, (ii) implementace dohodnutých evropských priorit pro rozvoj schopností, a (iii) rozvoj evropské spolupráce. ${ }^{15} \mathrm{~V}$ dalších letech se očekává, že CARD půjde více do hloubky a bude vedle výdajů na obranu mapovat i výdaje na investice a společné projekty, podrobněji analyzovat implementaci dohodnutých evropských priorit v rámci národního obranného plánování, a národní příspěvek do operací a misí CSDP i mimo ní, a to včetně NATO.

Tyto informace budou sbírány ve spolupráci s členskými státy (mimo jiné formou strukturovaných bilaterálních rozhovorů), následně analyzovány a přetvořeny ve zprávu CARD (CARD Report) vypracovanou pro každý členský stát zvlášt́ a současně v agregované podobě za členské státy jako celek. Celý proces bude řídit, podobně jako PESCO, sekretariát CARD pod hlavičkou EDA a ve spolupráci s EUMC a EEAS. ${ }^{16}$ Sekretariátu CARD se tak dostane pravidelného globálního přehledu o obranných aktivitách členských států a dosaženém pokroku při jejich implementaci. ${ }^{17}$ Konečným cílem je nahradit současný model obranné spolupráce v EU, pro který je charakteristická nahodilost a nesoulad, strukturovanou a synchronizovanou evropskou obrannou spoluprací založenou na společném obranném plánování a jeho systematické implementaci.

14 Ref. 3. S. 27; a Latest News: Outcome of EDA Ministerial Steering Board, Brusel, 20. listopadu 2018 [online]. [cit. 7. 9. 2019]. Dostupné z https://www.eda.europa.eu/info-hub/press-centre/ latest-news/2018/11/20/outcome-of-eda-ministerial-steering-board.

15 Factsheet: Coordinated Annual Review on Defence (CARD), European Defence Agency, 26. listopadu 2018 [online]. [cit. 7. 9. 2019]. Dostupné z https://eda.europa.eu/docs/ default-source/eda-factsheets/2018-11-26-factsheet_card.

16 Obecné informace ke CARD včetně jeho institucionálního ukotvení a procesu sběru informací od členských států jsou dostupné z https://www.eda.europa.eu/what-we-do/ourcurrent-priorities/coordinated-annual-review-on-defence-(card) a https://eeas.europa.eu/ headquarters/headquarters-homepage_en/36453/Coordinated\%20Annual\%20Review\%20 on\%20Defence\%20(CARD).

17 Informace získané v rámci CARD jsou až na výjimky neveřejného charakteru. 


\subsection{Evropský obranný fond}

Vedle PESCO a CARD je EDF další důležitou iniciativou a podstatným mezníkem v budování evropské obrany. ${ }^{18}$ Poprvé v historii EU je obranný výzkum a vývoj financován nebo spolufinancován ze společného rozpočtu EU, navíc na základě volné soutěže (nikoliv na základě garance návratnosti národního příspěvku do rozpočtu jako celku). Jeho spuštěním získala Evropská komise pevné místo mezi evropskými institucemi řešící evropskou obranu, Radou a EDA, které tak do určité míry ztratily dosavadní exkluzivitu $\checkmark$ realizaci obranné spolupráce. Navíc zaměřením EDF na obranný výzkum a vývoj, který je počáteční fází vzniku nového zbraňového systému, získala Evropská komise důležité slovo i v diskuzi o budoucích obranných schopnostech EU včetně jejich technického řešení a použitých mechanismů obranné spolupráce.

EDF je rozdělený do dvou tzv. oken (windows), okna výzkumu (Research Window) a okna schopností (Capability Window). ${ }^{19}$ Každé okno má svůj specifický způsob implementace i financování. U Research Window Evropská komise na základě podnětů od členských států sestavuje roční plán práce, na jehož základě se každoročně vypisují výzvy (calls), do kterých se následně hlásí řešitelé (z řad průmyslu, výzkumných center, univerzit) s možnými návrhy. Z nich je pak vybrán jeden vítězný, který se následně na základě př́slušné smluvní dokumentace realizuje a financuje $100 \%$ z rozpočtu EU. ${ }^{20}$ Evropská komise řídí celý proces, nicméně vlastní realizace byla na základě delegační dohody svěřena EDA. ${ }^{21}$ Celkem je na Research Window vyčleněno 90 mil. euro ročně do roku 2020 a 500 mil. ročně po roce $2020 .{ }^{22}$ Úvodní fáze do roku 2020 nese název Př́pravná akce obranného výzkumu (Preparatory Action on Defence Research), přičemž se očekává, že v rámci nového rozpočtové rámce EU na roky 2021-2027 (Multiannual financial framework for 2021-2027) již bude figurovat samostatná rozpočtová kapitola na obranný výzkum. ${ }^{23}$ Evropská komise samostatně nebo v rámci svých implementačních agentur, např́klad skrze svoji Výkonnou agenturu pro výzkum Research Executive Agency - REA), pak bude patrně odpovědná za implementaci tohoto okna namísto dosavadní EDA.

18 Sdělení Komise Evropskému parlamentu, Radě, Evropskému Hospodářskému a sociálnímu výboru a Výboru regionů: Vznik Evropského obranného fondu, $\operatorname{COM(2017)~295,~Brusel,~} 7$. června 2017 [online]. [cit. 20. 7. 2019]. Dostupné z https://eur-lex.europa.eu/legal-content/ EN/TXT/?uri=CELEX\%3A52017DC0295.

Ibid. S. 4.

20 Ibid. S. 7; a Factsheet: The European Defence Fund: Stepping up the EU's role as a security and defence provider, European Commission, březen 2019 [online]. [cit. 14. 9. 2019]. Dostupné z https://ec.europa.eu/commission/news/european-defence-fund-2019-mar-19_en.

21 Latest News: Commission and EDA sign Delegation Agreement for Preparatory Action on Defence Research, Brusel, 31. května 2017 [online]. [cit. 14. 9. 2019]. Dostupné z https://www.eda.europa.eu/info-hub/press-centre/latest-news/2017/05/31/ commission-and-eda-sign-delegation-agreement-for-preparatory-action-on-defence-research.

22 Ref. 18. S. 4.

23 Obecné informace $k$ PADR včetně jednotlivých výzev jsou dostupné z https://www.eda.europa.eu/what-we-do/activities/activities-search/ pilot-project-and-preparatory-action-for-defence-research. 
U Capability Window se jedná o dvě fáze: fázi vývoje a fázi pořizení. V rámci vývojové fáze je vyčleněno 500 mil. euro do roku 2020 a 1 mld. euro po roce $2020 .{ }^{24}$ Podobně jako u Research Window Evropská komise připravuje spolu s členskými státy plán práce a následně vypisuje jednotlivé výzvy (9 v roce 2019 a 12 v roce 2020) určené průmyslovým subjektům včetně malých a středních podniků, pro jejichž zapojení je $\mathrm{k}$ dispozici řada finančních bonusů. ${ }^{25}$ Evropská komise pak za asistence nezávislých odborníků vybere nejlepší návrh, který se následně začne realizovat za finančního přispění EU, u vývoje prototypů například ve výši $20 \%$ (v případě, že se jedná o prototyp, který je součástí projektu PESCO, se tento bonus navyšuje o dalších $10 \%$ ), ale $v$ některých případech i ve výši $100 \%$ (například u studií proveditelnosti). ${ }^{26}$ Ve výjimečných př́padech může Evropská komise přidělit finanční prostředky průmyslu na přímo, mimo veřejnou soutěž, jako např́klad u projektu Eurodrone - MALE RPAS (Medium Altitude Long Endurance Remotely Piloted Aircraft System). ${ }^{27} \mathrm{Na}$ implementaci projektů dohliží Programový výbor (Programme Committee) Evropské komise, přičemž realizace projektu může být na základě dohody mezi účastnickými státy svěřena EDA nebo Organizaci pro spolupráci ve vyzbrojování (Organisation Conjointe de Coopération en matière d'Armement-OCCAR), která je samostatnou mezinárodní organizací (mimo EU) sídlící v německém Bonnu a řídící velké vyzbrojovací programy. ${ }^{28}$ úvodní fáze do roku 2020 se jmenuje Evropský program rozvoje obranného průmyslu (European Defence Industrial Development Programme EDIDP) a je upravena v Nařízení (EU) 2018/1092 z roku 2018. ${ }^{29}$ U fáze pořízení, jenž je součástí okna schopností, se pak Evropská komise snaží formulovat nová schémata (návody) spolupráce a (vzorce) financování, které mohou členské státy využít v rámci svých akvizic, jež jsou plně realizovany a hrazeny z jejich zdrojů. ${ }^{30}$ Celková částka, která má být $v$ rámci EDF $\mathrm{k}$ dispozici dle návrhu nového rozpočtového rámce $\mathrm{EU}$, dosahuje pro obě

24 Ref. 18. S. 4.

25 Factsheet: The European Defence Fund: Stepping up the EU's role as a security and defence provider, European Commission; a News: European Defence Fund, European Commission, Brusel, 19. března 2019 [online]. [cit. 14. 9. 2019]. Dostupné z https://ec.europa.eu/ commission/news/european-defence-fund-2019-mar-19_en.

26 Ibid.; a Nařízení Evropského parlamentu a Rady (EU) 2018/1092 ze dne 18. července 2018, kterým se zřizuje Evropský program rozvoje obranného průmyslu s cílem podpořit konkurenceschopnost a inovační kapacitu obranného průmyslu Unie, Úřední věstník Evropské unie, 7. srpna 2018, Článek 11, Odstavec 2 [online]. [cit. 14. 9. 2019]. Dostupné z https://eurlex.europa.eu/legal-content/cs/TXT/?uri=CELEX:32018R1092.

27 Factsheet: Stepping up the EU's role as a security and defence provider: Supporting European defence in the current EU budget, European Commission, březen 2019 [online]. [cit. 14. 9. 2019]. Dostupné z https://ec.europa.eu/commission/news/european-defence-fund-2019-mar-19_en. Obecné informace $k$ OCCAR včetně jednotlivých programů, které OCCAR řídí, jsou dostupné $z$ http://www.occar.int/. Ref. 26. Nařízení Evropského parlamentu a Rady (EU) 2018/1092 ze dne 18. července 2018. 
okna částky 13 mld. euro, což z hlediska celkového objemu investic na obranný výzkum a vývoj řadí Evropskou komisi na přední prríčky v rámci EU (cca $23,5 \%$ ročně). ${ }^{31}$

\subsection{Mise a operace}

Kromě PESCO, CARD a EDF, které jsou a bezesporu budou hlavními agendami evropské obrany v príštích letech, mají v tomto ohledu své nezastupitelné místo také operace a mise CSDP. Jak je zřejmé z EUGS, a jejího implementačního plánu, EU má jasnou ambici stát se globálním aktérem a vytvořit „silnější Unii v obraně a bezpečnosti“, aby byla schopná efektivněji čelit současným hrozbám. ${ }^{32} \mathrm{~V}$ operační rovině to znamená být připraven reagovat na vnější konflikty a krize, budovat kapacity u partnerů, a chránit EU a její občany. ${ }^{33}$ Není proto překvapením, že EU je aktivní v prevenci konfliktů a jejich rešení, a je schopná mobilizovat nejen vojenskou, ale díky šíri svého záběru, $v$ rámci již zmíněného komplexního přístupu, i civilní složku. $V$ roce 2018 EU vedla šest vojenských misí a operací, a deset civilních misí, čítajících zhruba 5000 osob rozmístěných v Evropě, Asii a Africe. ${ }^{34}$ Mezi nejznámější patří EULEX Kosovo, zahájená v roce 2008 jako největší civilní mise EU mající za cíl pomoci při vytváření demokratických institucí a právního státu; EUNAVFOR MED operation Sophia, spuštěná v roce $2015 \mathrm{~s}$ cílem identifikovat a zneškodnit plavidla pašeráků nebo obchodníků s lidmi v jižním Středomoří; a EUTM Mali probíhající od roku 2013 jako vojenská výcviková mise pro Malijské ozbrojené síly, které by s její pomocí měly být lépe připravené bránit teritoriální integritu Mali a jeho obyvatele v návaznosti na útoky radikálních islámských skupin a změnu vlády v roce $2012 .{ }^{35}$ Jako všechny i tyto operace a mise mají za cíl dosáhnout tří priorit stanovených pro operace a mise $v$ rámci CSDP: stabilizovat daný region, posílit schopnost partnerské země odolávat

31 Ibid. Procentuální podíl vypočitán s přihlédnutím k celkovým výdajům na obranný výzkum a vývoj členských států EDA v roce 2017. Ty byly odhadovány na 7,9 mld. euro. Defence Data 2016-2017, Key Findings and Analysis. Brusel: European Defence Agency, 2018. S. 10. ISBN 978-92-95075-42-9.

32 Implementation Plan on Security and Defence, 14392/16, Council of the European Union, Brusel, 14. listopadu 2016. S. 2 [online]. [cit. 20. 7. 2019]. Dostupné z https://eeas.europa.eu/regions/ western-europe/17304/global-strategy-european-unions-foreign-and-security-policy_en. Ibid. S. 3.

34 EUROPEAN EXTERNAL ACTION SERVICE. European Union Common Security and Defence Policy, Missions and Operations: Annual Report 2018. Luxembourg: Publications Office of the European Union, 2019. S. 11. ISBN 978-92-9238-620-7. Dostupné z https://eeas.europa.eu/ headquarters/headquarters-homepage/22818/missions-and-operations-annual-report_en.

35 Obecné informace $k$ misím a operacím CSDP včetně aktuální stiuace jsou dostupné z https://eeas.europa.eu/headquarters/headquarters-homepage/430/ military-and-civilian-missions-and-operations_en. 
možným hrozbám, a zvýšit schopnost EU reagovat na všechny fáze konfliktu. ${ }^{36}$ Rozhodnutí o zahájení mise nebo operace je přijímáno Radou v rámci FAC, přičemž valnou většinu vybavení a personálu poskytují členské státy. Dohled na implementací má PSC. ${ }^{37}$ Velení vojenských operací pak připadá státu, který operací říí/jedná jako rámcový stát (Framework Nation). Alternativně může EU na základě ujednání Berlín plus využít velitelské sktruktury NATO. ${ }^{38}$ Vojenské a civilní mise jsou pak rízeny MPCC, respektive CPCC. ${ }^{39}$ K financování vojenských operací byl v roce 2004 zřízen tzv. Athena mechanismus, do kterého dle dohodnutého klíče přispívají všechny členské státy EU s výjimkou Dánska. ${ }^{40}$ Tento mechanismus by měl v budoucnu být nahrazen Evropským mírovým nástrojem (European Peace Facility - EPF), mimorozpočtovým fondem permanentního charakteru zřízeným v rámci nového rozpočtového rámce EU v navrhované hodnotě $8 \mathrm{mld}$. euro, do kterého by přispívaly všechny členské státy. ${ }^{41}$ Současně by se podstatně rozšíril rozsah společně financovaných nákladů operace, z 5-15\% v rámci Athena mechanismu až na 35-45\%, mající za cíl zvýšit účinnost operací a usnadnit rychlé nasazení vojsk pod vlajkou EU. ${ }^{42}$ Civilní mise jsou pak financovány z rozpočtu CFSP. ${ }^{43}$

36 EUROPEAN EXTERNAL ACTION SERVICE. European Union Common Security and Defence Policy, Missions and Operations: Annual Report 2016. S. 3. [online]. [cit. 21. 9. 2019]. Dostupné z https://eeas.europa.eu/headquarters/headquarters-homepage/22818/ missions-and-operations-annual-report_en

37 REHRL, Jochen, ed. Handbook on CSDP. Sv. 1. 3. vyd. Vídeň: Armed Forces Printing Centre, 2017. S. 81. ISBN 978-92-95201-05-7.

38 Factsheet: EU Missions and Operations, As part of the EU's Common Security and Defence Policy (CSDP), European External Action Service, 13. listopadu 2017 [online]. [cit. 21. 9. 2019]. Dostupné z https://www.consilium.europa.eu/en/policies/ defence-security/. Obecné informace $k$ ujednání Berlín plus jsou $k$ dostupné $z$ https://eeas.europa.eu/topics/common-security-and-defence-policy-csdp/5388/ shaping-of-a-common-security-and-defence-policy-_en.

39 Ibid. Factsheet: EU Missions and Operations, As part of the EU's Common Security and Defence Policy (CSDP).

40 Ibid. Obecné informace $\mathrm{k}$ mechanismu Athena jsou $\mathrm{k}$ dostupné $\mathrm{z}$ https://www.consilium. europa.eu/en/policies/athena/. K opt-out Dánska viz ref. 37. S. 165. Obecné informace k optouts Dánska v rámci EU jsou dostupné na https://english.eu.dk/en/denmark_eu/danishoptouts.

41 Obecné informace $\mathrm{k}$ Evropskému mírovému nástroji a souvisejícím otázkám jsou dostupné $z$ https://eeas.europa.eu/headquarters/headquarters-homepage/46285/node/46285_en.

42 DENECKERE, Matthias, The uncharted path towards a European Peace Facility. The European Centre for Development Policy Management (ECDPM). Discussion Paper no. 248, S. 4. ISSN1571-7577 [online]. [cit. 15. 6. 2020]. Dostupné z https://ecdpm.org/wp-content/uploads/ DP-248-The-uncharted-path-towards-a-European-Peace-Facility-ECDPM-March-2019.pdf.

43 Ref. 38. Factsheet: EU Missions and Operations, As part of the EU's Common Security and Defence Policy (CSDP). 


\section{JAK JE ČESKÁ REPUBLIKA ZAPOJENA DO BUDOVÁNÍ EVROPSKÉ OBRANY?}

Od vstupu do EU v roce 2004 je Česká republika zapojena do řady aktivit v rámci ESDP a později CSDP. Za ty podstatné je třeba zmínit EDA, kterou navíc od května 2020 na tři roky řídí z pozice Výkonného ředitele český diplomat Jiří Šedivý. ${ }^{44}$ Kromě tohoto mimořádného úspěchu se Česká republika v EDA účastní řady činností od výzkumných projektů zaměřených na ochranu před účinky zbraní hromadného ničení, přes společný nákup protitankové munice, účasti v projektu společného nákupu tankovací transportní flotily (Multi-Role Tanker Transport Fleet - MMF), až po aktivity zaměřené na vzdělávání akvizičních expertů a výcvik vrtulníkových posádek a specialistů na boj proti improvizovaným a výbušným prostředkům. ${ }^{45} \mathrm{~V}$ současnosti je Česká republika zapojena do 17 projektů, což s ohledem na velikost jejího obranného rozpočtu odpovídá relativně vyšší míre zapojení ve srovnání s ostatními členskými státy. ${ }^{46}$ Podobně aktivní je i v rámci PESCO, kde spolu s Belgií, Nizozemskem a Finskem podpořila společný dopis Francie, Německa, Itálie a Španělska z 21. července 2017 adresovaný Vysokému představiteli.47 Tento dopis obsahoval návrh přísnějších závazků a stal se klíčovým mezníkem pro vznik PESCO. Česká republika se v současnosti účastní devíti PESCO projektů, z nichž jeden koordinuje, a v dalších devíti je pozorovatelem. ${ }^{48}$ Každoročně připravuje svůj NIP, který se těší relativně dobrému hodnocení ze strany sekretariátu PESCO. ${ }^{49}$ Česká republika je také aktivní v CARD a EDF, kde v rámci prvních výzev pro Research and Capability Window, spadajících pod EDIDP, již uspěly dva české subjekty. ${ }^{50}$ Co se misí a operací CSDP týče, ze současných šesti vojenských misí a operací se Česká republika účastní Operation Althea, EUNAVFOR MED IRINI a EUTM Mali, kde je po Španělsku druhým největším přispěvatelem jednotek do mise, a od června 2020 do ledna 2021 této misi v osobě

44 Latest News: Jiří Šedivý takes office as new EDA Chief Executive, Brusel, 5. května 2020 [online]. [cit. 16. 6. 2020]. Dostupné z https://www.eda.europa.eu/info-hub/press-centre/latest-news/2020/05/05/ jiř\%C3\%AD-šedivý-takes-office-as-new-eda-chief-executive.

45 Interview s Ing. Danielou Baluchovou, Ministerstvo obrany, Sekce obranné politiky a strategie, Odbor obranné politiky, Brusel, 14. listopadu 2019.

46 Ibid.

47 Ref. 3. S. 33.

48 Press release: Defence cooperation: Council launches 13 new PESCO projects, Permanent Structured Cooperation (PESCO)'s projects - Overview, Council of the EU, 12. listopadu 2019 [online]. [cit. 16. 11. 2019]. Dostupné z https:eda de//www.consilium.europa.eu/en/press/ press-releases/2019/11/12/defence-cooperation-council-launches-13-new-pesco-projects/.

49 Interview s Mgr. Ondřejem Šamonilem, Ministerstvo obrany, Sekce obranné politiky a strategie, Odbor strategického rozvoje, Praha, 3. ř́jna 2019.

50 Firma TOVEK uspěla v projektu PEONEER a sdružení CESNET v projektu PRIVILEGE. Obecné informace k výsledku prvních výzev jsou dostupné z https://ec.europa.eu/info/publications/ european-defence-industry-results-calls_en. 
brigádního generála Františka Ridzáka i velí. ${ }^{51}$ Česká republika je zastoupena i v civilních misích. Ze současných jedenácti civilních misí se účastní EULEX Kosovo, EUMM Georgia, EUAM Ukraine, EUCAP Sahel Niger a EUCAP Somalia. ${ }^{52}$

Navzdory relativně aktivní roli v CSDP, především v EDA, PESCO, ale i v misích a operacích, je zapojení České republiky do budování evropské obrany stále pod jejím potenciálem. Důvodů je mnoho. Na straně jedné chybí potřebné politické zázemí a ospravedlnění pro širší a intenzivnější účast. Na straně druhé nejsou vytvořeny příhodné podmínky, které by širší a intenzivnější účast umožňovaly. K prvnímu aspektu je třeba připomenout, že pro Českou republiku byla obrana státu po desetiletí z hlediska priorit spíše „nechtěným dítětem" a členství v NATO vítaným řešením, jak ji relativně snadno a levně zajistit. CSDP byla v tomto kontextu považována za zbytečnou, duplicitní agendu, přinášejíć České republice více problémů než řešení. $S$ nástupem Trumpovy administrativy však transatlantická vazba oslabuje a nad budoucností NATO, které je jejím hlavním ztělesněním, visí řada otazníků. ${ }^{33}$ Posilování evropské obrany se tak nabízí jako vhodný doplněk nebo $v$ budoucnu dokonce jako vhodná alternativa vůči NATO. Třebaže obrana není mezi ostatními domácími politickými tématy stále prioritou, Česká republika vnímá horšící se geopolitickou situaci a oslabování NATO a snaží se navyšovat obranný rozpočet. Ten však stále velikostí i objemem investic zaostává za ostatními členskými státy EU, ${ }^{54}$ což ve svém důsledku brání vytvoření příhodných podmínek pro širší a intenzivnější účast v mezinárodních projektech v rámci CSDP - druhý aspekt. To v kombinaci s malým zastoupením Čechů v evropských institucích řešících evropskou obranu (zejména v Radě a Evropské komisi) a z toho pramenící omezený prístup $\mathrm{k}$ informacím a rozhodovacím procesům, nedává České republice př́lilš šancí na změnu přístupu a posílení její účasti. Vliv České republiky na realizaci evropské obrany včetně prosazování národních zájmů (napríklad podporou zapojení českých průmyslových subjektů a vědeckých center do evropských projektů) tak v konečném důsledku zůstává úměrný malé politické ambici a omezeným výchozím podmínkám.

Ke zvy̌šení účasti České republiky a posílení jejího vlivu na budování evropské obrany je nutné, aby čeští politici ukázali jasný směr a česká státní správa vytvořila sít podpưrných politik, nástrojů, a procesů, kterými by politické zadání přetavila v konkrétní mechanismy, jež budou fungovat ve prospěch státu a jeho součástí nutných $k$ zajištění obrany státu včetně vědeckých center zkoumajících vojenské technologie budoucnosti, průmyslu, který je bude vyrábět, a pracovníků státní správy, kteří je v rámci národních nebo mezinárodních projektů budou v rádech miliard nakupovat. Stabilita domácího vedení, řízení a plánování, spolu se širokým expertním zázemím, a zvyšování českého zastoupení

51 Interview s Petrou Hojni, Stálé zastoupení ČR při EU, Oddělení společné zahraniční a bezpečností politiky, Brusel, 16. června 2020; a Ing. Jiřím Juříkem, Ministerstvo obrany, Sekce obranné politiky a strategie, Odbor obranné politiky, 15. června 2020.

52 Ibid.

53 Nato alliance experiencing brain death, says Macron, BBC News, 7. listopadu 2017 [online]. [cit. 16. 11. 2019]. Dostupné z https://www.bbc.com/news/world-europe-50335257.

54 Evropa zvyšuje výdaje na obranu, Česko spadlo na páté místo od konce, iDnes.cz, 28. června 2019 [online]. [cit. 16. 11. 2019]. Dostupné z https://www.idnes.cz/zpravy/nato/vydaje-natoobrana-cesko-aliance-armada-rozpocet-trump-stoltenberg.A190628_162040_zpr_nato_inc. 
ve strukturách EU, jsou nezbytnými výchozími podmínkami, bez nichž nelze v dohledné době očekávat výraznější posílení účasti ČR v procesu budování evropské obrany. To $v$ kontextu změny prístupu EU $\mathrm{k}$ evropské obraně a celkové snahy o akceleraci tohoto procesu s pomocí nových finančních nástrojů na podporu obranného průmyslu, realizovaných ze společného rozpočtu EU, přestává být jen akademická debata, ale politická i ekonomická nutnost. Např́klad v kontextu EDF/EDIDP se jedná o otázku budoucí podoby EDTIB a přežití jednotlivých evropských firem včetně těch českých: ten, kdo uspěje v čerpání finančních prostředků z EDF/EDIDP a zapojí se do společných projektů, bude mít do budoucna více zdrojů a šancí posílit svoji konkurenceschopnost a udržet se na trhu než ten, kdo zůstane stranou a finanční prostředky z EU nezíská.

\section{ZÁVĚR: JAKÁ JE BUDOUCNOST EVROPSKÉ OBRANY?}

Diskusní dokument o budoucnosti evropské obrany, který Evropská komise vydala v roce 2017, a který byl zmíněn výše v souvislosti s rostoucí angažovaností Evropské komise $v$ této oblasti, nastiňuje tři obecné scénáře: Spolupráce v oblasti bezpečnosti a obrany (Security and Defence Cooperation), Sdílená bezpečnost a obrana (Shared Security and Defence), a Společná obrana a bezpečnost (Common Defence and Security). ${ }^{55}$ Jak je již z názvư patrné, jednotlivé scénáře se liší především výší závislosti a soudržnosti mezi jednotlivými členskými státy EU. První scénář, který je de facto popisem současné situace klade hlavní důraz na dobrovolnost z hlediska zapojení do budování evropské obrany, která je většinou ad hoc na základě principu výhodnosti, a to včetně zapojení do misí a operací EU, obranného plánování, a vývoje a výroby nových zbraňových systémů. ${ }^{56}$ Druhý scénář hovoří o vyšší finanční a operační solidaritě umožňující EU provádět operace s vysokou intenzitou k obraně Unie a jejich obyvatel. Na jejich podporu by byly zřízeny společné plánovací a velitelské struktury. Obranná spolupráce mezi členskými státy EU by se stala pravidlem, spíše než výjimkou, včetně společného obranného plánování a pořízení. ${ }^{57}$ Třetí scénář, který jde z hlediska koheze nejdále, mluví o společné obranné politice Unie vedoucí ke společné obraně. ${ }^{58}$ Závazek solidarity a vzájemné pomoci by se podle tohoto scénáře stal neměnitelným, což by ve faktické rovině bylo podpořeno vysokou mírou integrace ozbrojených sil členských států EU, synchronizací obranného

55 Diskusní dokument o budoucnosti evropské obrany, Evropská komise, $\operatorname{COM(2017)~315,~}$ Brusel, 7. června 2017. S. 12-15 [online]. [cit. 17. 8. 2019]. Dostupné z https://ec.europa.eu/ commission/publications/reflection-paper-future-european-defence_en.

Ibid. S. 12-13.

57

58 Ibid. S. 13-14.

Ve smyslu Článku 42, Odstavce 2, Smlouvy o Evropské unii. Hlava III, Ustanovení o orgánech, Společná bezpečnostní a obranná politika, Kapitola 2, Zvláštní ustanovení o společné zahraniční a bezpečnostní politice, Oddíl 2, Ustanovení o Společné bezpečnostní a obranné politice. Lisabonská smlouva pozměňující Smlouvu o Evropské unii a Smlouvu o založení Evropského společenství (2007/C 306/01), Úřední věstník Evropské unie, 17. prosince 2007 [online]. [cit. 13. 7. 2019]. Dostupné z https://eur-lex.europa.eu/legal-content/HR/TXT/?uri=CELEX:12007L/TXT. 
plánování dle na evropské úrovni definovaných priorit, a společného nákupu většiny klíčového vybavení včetně hlavních zbraňových systémů od evropského průmyslu v rámci plně funkčního EDEM. EU by tak byla fakticky schopná s využitím vlastních zdrojů a prostředků razantně zasáhnout kdykoliv a kdekoliv k odražení agrese proti Unii a jejím obyvatelům. ${ }^{59}$

Třebaže se zatím jedná jen o teoretické scénáře, je již dnes ve světle výše uvedeného zřejmé, že dříve nebo později projde CSDP další proměnou. Zásadní změna institucionální rámce a souvisejících procesů nastane patrně až s další revizí zakládajících smluv (Lisabonská smlouva je v platnosti již více něž deset let), nicméně dílčí změny lze očekávat již dríve. V roce 2020 se očekává strategická revize PESCO, první ostrý cyklus CARD, vypsání dalších výzev $v$ rámci EDIDP a konečně i schvalování nového rozpočtové rámce EU na roky 2021-2027, ve kterém by měla mít obrana zejména prostřednictvím EDF podstatné zastoupení. Současně se hovoři o zřizení plnohodnotného operačního velitelství, reformě EDA a dalších orgánů Rady s cílem jednak zefektivnit velení operací a misí CSDP, jednak harmonizovat a konsolidovat definici priorit pro oblast schopností včetně dohledu nad jejich implementací a současně posílit exekuční část ve smyslu efektivnější realizace společných projektů výzkumu a vývoje a programů vyzbrojování.

EU se tak pomalu ale jistě propracovává od scénáře jedna ke scénáři dvě, pro který bude mimo jiné charakteristická všeobecná akceptace obrany jako jedné z plnohodnotných politik EU doprovázená vyšší konvergencí obranných politik členských států. Ta se bude projevovat četnější a intenzivnější obrannou spoluprací jdoucí od obranného plánovaní až po společné pořízení, pro které bude navíc $k$ dispozici více a více finančních pobídek $v$ duchu EDF/EDIDP. Zda díky tomu bude EU schopná lépe čelit výzvám podobným válkám na Balkáně, které na počátku devadesátých let odstartovaly tvorbu evropské obrany a CSDP do podoby, v jaké ji známe dnes, však zůstává otázkou. EU má bezesporu blíže $k$ efektivnější reakci na podobné krize, než měla v devadesátých letech, ale je stále velmi daleko od schopnosti efektivně a rychle generovat ozbrojené síly členských států, rozmístit je a z jednoho centra velet jejich bojovým operacím, nemluvě o ochotě a připravenosti členských států takové síly poskytnout a financovat jejich nasazení. Přesto, anebo právě proto, EU v posilování obranné dimenze nepoleví. S ohledem na zhoršující se geopolitickou situaci Ize naopak očekávat, že své snažení ještě uspíší. Jak poznamenal první americký prezident George Washington v době americké války za nezávislost: „Být připraven na válku je jedním z nejúčinnějších způsobů zachování míru.“60 Současné tempo budování evropské obrany svědčí o tom, že EU si z něho vzala jasné ponaučení.

\section{První část článku byla uveřejněna ve VR 3/2020.}

59 Ref. 55. S. 14-15.

60 WASHINGTON, George. First Annual Address to Both Houses of Congress. 8. ledna 1790 [online]. [cit. 12. 10. 2019]. Dostupné z https://www.mountvernon.org/library/digitalhistory/quotes/ article/to-be-prepared-for-war-is-one-of-the-most-effectual-means-of-preserving-peace/. 
Autor: $\quad$ PhDr. Vilém Kolín, Ph.D., MGS, narozen 1974. Titul Ph.D. získal v oboru Mezinárodní vztahy na Fakultě sociálních věd Univerzity Karlovy v Praze. Dále studoval na Joseph Korbel School of International Studies Univerzity $v$ Denveru v USA. V letech 2005-2006 pracoval jako vědecký pracovník v Ústavu strategických studií Univerzity obrany v Brně, v letech 2006-2010 na Sekci vyzbrojování Ministerstva obrany. Od roku 2010 pracuje v Evropské obranné agentuře (EDA) v Bruselu. Zaměruje se na problematiku Společné obranné a bezpečnostní politiky EU, obranného výzkumu, průmyslu a trhu a realizace mezinárodních projektů a programů.

Jak citovat: KOLÍN Vilém. Společná bezpečnostní a obranná politika EU v kostce - část druhá. Vojenské rozhledy. 2020, 29 (4), 105-117. ISSN 1210-3292 (print), 2336-2995 (on-line). Available at: www.vojenskerozhledy.cz. 


\section{Otiskli jsme před 100 lety}

Předkládáme vám text z rubriky „Vojenství doma i v cizině“ publikovaný v našem časopise č. 4/1920.

Tento i další historické články si můžete prohlédnout, přečíst nebo stáhnout na webových stránkách našeho časopisu www.vojenskerozhledy.cz v nabídce archivu.

\section{VOJENSTVİ DOMA A V CIZINĔ. Vojenská smlouva Francie s Belgii. ${ }^{*}$ )}

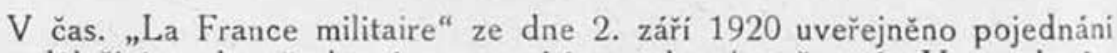
o této dủležité smlouvě, která se mezitím stala skutečností. V uvedeném pojednáni pravi se $\mathrm{v}$ podstatě toto:

Jestliže $v$ této smlouvě vidi Belgie podle výpovědi belgického ministra války $M$. Jansona záruku proti budoucim válkám a jakési předpoklady $k$ jiným dohodám s Francii, tato opět jest šfastna, že mohla tuto smlouvu uzavriti a podepsati. Smlouva tato navždy odstraňuje nepřetržité nebezpeči, jemuž byly neutralitou Belgie oba státy vystaveny.

Smlouva obsahujé společný plán pro ochranu mobilisaceaprosoustředěni vojsk v prípadě útoku naBelgii nebo Franciis východu.

V prvém námětu smlouvy navrhoval belgický generálni štáb soustředěni belgických vojsk $v$ trojúhelniku Bruxelles-Malines-Louvain. Pečlivé studium mapy však ukázalo, že toto pásmo jest přiliš vzdálené od hranice. Rovněz i pevnost Antverpy, která méla sloužiti jako jảdro belgické obrany, byla po zkušenostech z roku 1914 zamitnuta; jádro obrany bylo preneseno na jiné misto, které ovšem neni jmenováno, které však neni těžko uhodnouti.

*) Autor žádà o laskavé zasiláni studii a prispěvkủ, které souvisi s materielni službou a $s$ uvedeným konečným dủsledkem.

") Viz „Vojenské Rozhledy", roč. I., čis. 3.-4., strana 235 
Ministr války M. Janson vyslovil se o této smlouvě takto: „Tato smlouva jest jasná a jednoduchá. Ustanovuje, že $v$ prípadě neoprávněného napadnuti přislibuji si vzájemně obě země plnou vojenskou oporu a utvoři jedinou a společnou frontu. Nyni jsme sice na Rýně, pozitři múžeme však býti napadeni; proto jest zapotřebi, abychom se společně hájili. Máme čekati teprve na posledni okamžik, abychom si pak společnou obranu improvisovali, nebo máme ji již nyni organisovati?“"

Nejlepši odpovědi jest uskutečněni zamyšlené vojenské smlouvy. - -akk

\section{Reorganisace dělostřleckých velitelstêv ve francouzské armádè.}

V čas. „La France militaire“ ze dne 9. záři t. r. zabývá se plukovník O. B. reorganisaci velitelstev u francouzského dělostřelectva, která byla nařizena dekretem ze dne 18 . srpna 1920.

Před válkou a po demobilisaci byly dělostřelecké pluky ve svazu dělostřeleckých brigád za veleni generála, velitele sborového dělostřelectva, který přimo podléhal veliteli sboru. Divisionári takto nedisponovali svým dělostřelectvem, leda při velkých manévrech.

Vydánim dekretú ze dne 25. února 1910 a 8. listopadu 1911 nebylo tomuto organisačnimu nedostatku odpomoženo. Těmito dekrety bylo totiž pouze nařizero, že divisionár̆i jsou $\mathrm{i} v$ miru zmocněni $\mathrm{k}$ přehlidkám divisniho dělostřelectva, a tato že má sloužiti $k$ dohledu nad válečnou připravou a výcvikêm dủstojnikủ a dělostřeleckých oddilů se zřetelem na spolupráci rủznych zbrani.

Pouhả přehlidka a veleni jsou však dvě rủzné věci. Oba dekrety byly skutečně bojácné a netroufaly si zlomiti starý předsudek o „s pecielni ch" zbranich.

Dekret, který byl vydán dne 18 . srpna 1920 jest radikálnějši. Od nynějška budou divisionári jak $\mathrm{v}$ míru tak i ve válce veleti svému divisnimu dělostřelectvu, to znamená, že divisni dělostřelectvo jest jim přimo podřizeno.

Novým dekretem se zároveň ustanovuje stálý velitel divisniho dělostřelectva. Tim, že divisnimu dělostřelectvu bude veleti stálý generál neb plukovnik, obdrži divisionár dva spolupracovniky stejné hodnosti (velitele divisni pěchoty a velitele divisniho dělostřelectva). Divisionár̆ má nyní možnost zabývati se pouze všeobecnými, společnými otázkami, a specielni otázky přenecháva veliteli divisni pěchoty a veliteli divisniho dělostřelectva.

Dekret též ustanovuje zařaděni nosných $7.5 \mathrm{~cm}$ dělostřeleckých plukũ (régiments d'artillerie portée) do svazku divisniho dělostřelectva. Tyto pluky, které vlastně tvoři všeobecnou dělostřeleckou zálohu, maji takto možnost již v miru zvykati si na spolupráci s divisnim dělostřelectvem a na pěchotu, k čemuž jsou vlastně ve válce povoláni.

$\mathrm{S}$ vývody plukovnika $\mathrm{O}$. B. možno jen souhlasiti. Též v rakouské armádě neměl v míru divisionář práva veleni, což se zvláště na začảtku války zle vymstilo. Divisionár̆ často neznal ani velitele divisniho dělostřelectva, což teprve plukovniky a ostatni vyšši düstojniky.

Tito byli opět úplně cizi plukủm pěšim. Za takových okolnosti nebylo pak možno požadovati účinnou spolupráci dělostřelectva s pěchotou.

Doufáme, že $v$ naši přšsti organisaci bude na tyto dúležité zásadni otázky vzat náležitý zřetel. $H K$. 


\section{Rumunská armáda a jeji organisace. \\ (Zprảva ukončena 15. rijna 1920.) \\ 1. Organisace veleni.}

Nejvyššim velitelem rumunské armády jest král.

Výkonnými orgány jsou :

a) v miru: ministerstvo války a generálni štáb;

b) ve válce: hlavni stan, do něhož pak přejde větši část gen. štábu.

Zbytek gen. štábu zûstane $v$ zápoli pro řizeni běžných záležitosti ve vnitrozemi a dostává instrukce od hlavniho stanu prostřednictvim ministerstva války.

\section{A. Hlavnistan.}

Náčelnikem jest generál divise neb vyšši generál. Má dva podnáčelniky. Jeho činnost pozústává v rozhodováni a dozoru nad všemi pracemi, které se týkaji války. Rozdēluje se na dvě hlavni odděleni s rủznými sekcemi.

\section{B. Generálni štáb.}

Š́fem generálniho štábu jest generál. Rozděleni gen. štảbu odpovidá $\mathrm{v}$ celku rozděleni hlavního stanu.

\section{Organisace vyssšich jednotek.}

Rumunsko reorganisuje a zesiluje svoji armádu.

Před válkou existovalo pět armádnich sborù; tento počet hodlá rumunská vojenská správa rozmnožiti na osm. Doposud je sestaveno sedm armádnich sborủ (6. armádni sbor jest $\mathrm{v}$ Kluži, 7. armádni sbor $\mathrm{v}$ Sibini). 8. armádni sbor se projektuje $\mathrm{v}$ Besarabii. Každý armảdni sbor pozūstává: ze dvou aktivnich a jedné záložni divise.

Celkem má nyni rumunská armáda 14 aktivnich pěšich divisi, 7 reserv. ních divisi a 2 střelecké divise. Aktivni divise maji čisla $1-14$, záložni divise čisla $15-21$, střelecké divise zvláštni čislo 1 a 2 . Divise čislo 22 a 23 maji se utvoŕiti v Besarabii, čislo $24 \vee$ Bukovině; tam jest postavena prozatim jedna brigáda (t. zv. bukovinská).

\section{Složeni pěši (aktivni) divise.}

A. $\breve{\mathrm{S}} \mathrm{tả} b$ divise. Kancelăr : séf štábu, operačni, zpravodajská, osobni a administrativni.

Referảt: délostrelecký, technický, zdravotnický a intendančni.

Kanceláŕ služeb : zásobovaci, oděvnická, policejni, poštovni a telegrafická. Umisfovaci služba.

B. Vojsko: a) pěchota: 1 střelecký pluk, 2 brigády po 2 pěšich plucich (tyto pluky jsou podřizeny streleckým divisim). b) jizda: 2 eskadrony; c) dělostrelectvo: 1 brigáda; d) technické vojsko: 1 prapor pionýrú.

C. Služby: Munični kolona pro dělostřelectvo a pěchotu. Zdravotnická kolona skládá se ze dvou sekci s polnimi nemocnicemi. Proviantni kolona skládá se ze tř́ oddéleni (272 vozú). Polni policie. Etapni formace a polni doplñovaci jednotky.

Zảložni divise maji bud dvé brigády po ètyrech plucich nebo čtyri brigády po dvou plucich.

Tyto sily jsou rozděleny mezi tři armádni inspekce:

I. v Bukurešti pro 1., 2., 5. armádni sbor a 1 divisi jizdy;

II. v Sibini pro 6., 7. armádni sbor a 1 divisi jizdy;

III. $v$ Jassech pro $3,4 ., 8$, armádni sbor a 1 divisi jizdy. 
Všechny armádni sbory a inspekce jsou opatřeny všemi prostředky modernich armád (těžké dělostřelectvo, letectvo, moderni prostředky dopravni atd.

\section{Délostřelectvo, jizda, technické sbory.}

O těchto formacich a jejich organisaci neni doposud podrobných zpráv. Přes značné množstvi materiảlu ukořistěného v Uhrách a jiných oblastech nedosáhlo divisijni dělostřelectvo předepsaného stavu. Pokud jest známo, má Rumunsko 3 jizdni divise, jejichž organisace a sila jest dosud neznáma.

\section{Letectvi.}

Reditelem vzduchoplavby jest generál v ministerstvu války.

Letecký sbor děli se na pět skupin, jeden záložni park a jeden balonový sbor.

Prvni letecká skupina jest v B ukur eš ti. Pozůstává ze 2 eskadril, 1 parku, 1 roty balonú, 1 fotografické sekce a 1 sekce hydroplánů.

Druhá letecká skupina v Bacou má 3 eskadrily, 1 park, 1 fotografickou sekci.

Třeti letecká skupina $\mathrm{v} \backslash \mathrm{R}$ em a u se 2 eskadrilami, 1 parkem, 1 fotografickou sekci. neznáma.

Letecká skupina pro Transylvanii. Misto, organisace a sila dosud

Pátá letecká skupina pro Besarabii v Kišiněvu má 3 eskadrily, 1 park a 1 rotu balonù.

Efektivni stav ćini 6.000 důstojniků a mužù. Počet strojú jest dosti obmezený a neni znám. Rumunská vojenská aviatika má býti reorganisována a pro každý armádni sbor bude vybudována jedna letecká skupina se vším potřebným materiálem.

\section{Doplñováni, mobilisace a demobilisace.}

Rumunsko provedlo odvody všech mužủ z přivtělených oblasti Bukoviny, Banátu a Sedmihrad. Jak se postupuje v Besarabii, neni známo. Ročniky 1917, 1918, 1919 a 1920 jsou úplně pod prapory. Ročniky starši jsou na dočasné dovolené. Neni zaručeno, zda ročnik 1916 jest úplně propuštěn.

Demobilisace rumunské armády jest zamýšlena na stanovenou výši 160.000 mužủ se dvěma ročniky ve zbrani. Tato možnost jest však závislá od události v Rusku a proto se Rumunsko snaži všemožně vystřici se všeho, co by porušilo jeho neutralitu $k$ Rusku.

Otázku doplňováni dủstojnického sboru rozřešila vojenská správa zpũsobem velmi př́iznivým býv. rak.-uherským dủstojnikủm. Bývali rakoušti dủstojnici rumunské a německé národnosti, kteři jsou př́slušni domovským právem do nynějšiho rumunského územi, byli převzati do královské rumunské armády $v$ hodnosti o jeden stupeň vyšši. Byli přijati v audienci králem, který vyslovil očekáváni, že věnuji všechny své sily k vybudováni nové vlasti, Velkého Rumunska.

Za žádných podminek nejsou prijiimáni dũstojnici madarské národnosti.

U technických zbrani (pionýri, železnični, telegrafni, letečtí a automobilni dủstojnici) přijimaji se též dústojnici cizich státủ (Madary opět vyjímaje) až do pořadi včetně mladšich podplukovnikû.

Unifikace rumunských dủstojnikủ $s$ bývalými důstojniky rakouskými děje se bez potiži a třenic, prriznivě a rychle.

\section{Válečný materiäl.}

Výzbroj rumunské armády, aspoň pěši jeji části, jest dobrá. Vojsko je vyzbrojeno $6.5 \mathrm{~mm}$ manlicherovou opakovačkou M 93. Jest ovšem otázkou, 
dostači-li pěši vỷzbroj pro soustavné zvyšováni armády. Přes to, že po shrouceni střednich velmoci zabralo Rumunsko veliké zásoby zbrani všelikého druhu a za okupace $v$ Uhrách ukořistili všechna skladiště, prece utrpělo Rumunsko ve světové válce veliké ztráty válečného materiảlu.

Stávajici zásoby rozhodně nevystači k vyzbrojeni nové velké armády. Velký nedostaték materiálu pocituje se zejména u délostrelectva a technických zbrani.

\section{Vystroj.}

Stejnokrojú jest dosti. Pěši výstroj jest dobrá a jest ji dostatek. Mezery jevi se však u dělostřelectva a technických vojsk.

Válečný prùmysl domácí neni mnoho vyvinut a stěži by výkonnost jeho uspokojila nynějši velikou potřebu pro velkou armádu. Proto jest Rumunsko odkázáno na objednávky, hlavně ze zbrojovek čskoslovenských, rakouských, německých a částečně $i$ italských.

\section{Válečná chirurgie u Homera.}

Úspěchy lékařské vědy za války světové povzbudily zdrav. radu Dra. Kruschwitze z Altenburgu v Německu $k$ tomu, że se opět vrátil ke svému Homerovi a pátral, zdali slavná Ilias a Odysseia nepodává nẻjakých zpráv o činnosti starovẻkých lékarù ve válce. *)

Vidíme, že již tehdejsi hrdinové pred 3000 lety nebyli bez lékařského ošetrováni. Počátky lékařského umĕni starých Rekủ vycházeji z Egypta. Když Telemachos, hledaje otce svého Odyssea, prišel do Sparty ke králi Menelaovi, nalila mu Helena, chof krále Menelaa, do vina kouzelný prostředek, aby zapomnél na svủj bol. Praotcem lékaŕstvi byl Asklépios (lat. Aeseulapius), jehož synové Podaleirios a Machaon byli lékaři a vủdei Achaiủ ") ve výpravě proti Troji. (llias, zpèv IV., verš 193 n.).

Stařičký Nestor, který se též účastnil války trojské, nemohl se již pro své vysoké stári bojủ zúčastniti. Zasloužil se však tim, že shromaždoval raněné a dal je donésti do svého stanu nebo na svou lod. Ranèným bylo podáno nejdřive občerstveni (vždyt i dnešni zdravotni oddily nosi pŭi sobé polni láhev s osvěżujicim nápojem) a byli vykoupáni v teplé vodé, která pravděpodobně byla takto zcela nevědomky sterilisována. Již tenkrate zabrauovali studenou vodou mdlobě raněných. Rány, na něž byly nejdríve prikládány hojici masti, byly jemným. plátnem obvázány.

Kdyż raněn byl král Menelaos, přivolán $k$ němu lékar̆ Machaon, který

„když prohlédl mu rảnu, kde šip vnikl Tandara trpký.

vyssàv krev pŕiložil hojivé na ni léky znalecky,

jež daroval jednou $\mathrm{z}$ prútelstvi otcovi Cheiron." *wo

(Ilias, zpèv IV., verš 217 n.)

Homer pëje též chvalozpéy na lékare, v němż se prosi stařičký Nestor, aby na své lodi peçlivě ošetroval raněného Machaa a ućinil jej brzo opét boje schopným:
„Nestore Neleovče, ty velká pýcho Achaiü,
vzhủru na vŭz rychlý svủj vystup a vedle Machaon vstoupniž a žeñ na kvap ku lodím koné jednokopytné. ježto cenou lékar̆ mnoho mužstva jiného preváżi. z ran vyřezávả šipy a vkládá léky hojici."
(llias, zpèv XI., verš $511 \mathrm{n}$.)
"Nuž zachrañ mne nyni a doved $k$ černému korábu, šip ze stehna vyrizni a smyj pak krev s nẻho černou čistě vodou vlažnou a nasyp svrchu léky hojici, výborné, jimž prý naučil tebe vládce Achilleus, jejž Cheiron vyučil, z Kentaurủ nejzbožnější.
Neb naši lékařové Podaleiros a vládce Machaon -

*) Výtěžek jeho studia neni rozsảhlý. Jest uveřejněn v časopise „Korrespondenzblatt für Thüringer Ärzte" (roč. 1920, ěis. 8, -9.).

**) Homer nazývi recké vojsko pred Trojou bojujici Achajské, Argejské, Danajské: pozdēji nazývali se jménem společným Hellenové.

**) Cheiron byl věhlasný lékar̆ Hellenủ, jenž sidlil na hoře Peliu a vychoval Jasona, Achillea $\mathrm{i}$ jiné znamenité bohatýry $v$ dobé herojské. - Ukázky z Homerovy lliady citovány jsou z prekladu Ant. Śkody, vydaného nákladem Ćeské Akademie v "Bibliotéce klassikú řeckých a rimských." 
ve stanu tento leži, myslim, maje ránu bolestnou.

potrebný jsa nyni sảm lékaře bezvadného,

kdežto druhỷ trojské na pláni krutou vede pútku.

(Ilias, zpěv XI., verక̌ $828 \mathrm{n}$.)

Tak dèl a pod paži ho chopiv vedl vévodu mužstva

do stanu; spatríiv jej soudruh, z tura kúži mu prostřel.

Tam položiv tedy vládce, nožem ze stehna vyr̈izl

ostrý šip trpký a vymýval krev jemu ćernou

čistê vodou vlažnou a vsypal mu na ránu kor̆inek

trpký, roztrolený, bolokojný, jenž mu bolesti

všecky ztišil; krev přestala téci a rána mu zaschla."

(llias, zpěv XI., veršs 842 n.)

Ilias vypravuje nám o tom, kterak trojský hrdina Agenor príložil jednomu raněnému zatimni obvaz, který nosil pri sobě jako dnešni vojini v poli. (Ilias, zpěv XIIl., verš 597 n.) Priklady tyto, jichż by ké ješté mnoho našlo, ukazuji, že homeršti hrdinové nebyli v boji bez lékar̉ského ošetreni.

Také ošetrovatelky najdeme ve válce trojské. Byly to otrokyně, které tuto službu ošetřovatelskou vykonávaly. Staři Rekové znali téż uspávaci a omamujici prostředky. Podle učinkủ bylo to asi opium nebo hašiš. U Homera najdeme též znatelné stopy po hygiené: desinfekce mrtvých, spalováni mrtvých, desinfekce mistnosti morem zamoŕených sirným výparem atd.

Ovšem o nějaké organisované zdravotni službé neize v těch dobách ještě mluviti. Služby lékařské provadẻli též králové a vủdcové, kteři zastávali i úrad kněžský. Tito zbavovali se však znenảhla této troji služby.

Uvážime-li, že homerské zpěvy zaznamenány byly asi roku 800 př. $\mathrm{Kr}$. a pủvodem svým jsou ješté o několik stoleti starši, ale že otec lékařské vě dy Hippokrates narodil se teprve asi v roce 456 , musime se obdivovati účelnosti zdravotnich zar̆izeni a znalostem lékařským ze šerých dob starovèku.

\section{Organisace pěchoty ve světové válce.}

Zákopová válka měla pronikavý vliv na organisaci pěchoty u vš̉ech bojujicich armád Revue ..Kungl. Krigsvetenskap-Akademiens Handlingar och Tidskrift" podává ve svém 22. -23. čisle zajjimavé tabulky o organisaci pěchoty, které niže podáváme, (Sron. téż „Schweizerische Vierteljahrschrift für Kriegswissenschaft, roč. 1920, čis. 3.).

A. Organisace pěchoty na počátku války r. 1914.

\begin{tabular}{|c|c|c|c|c|c|}
\hline Jednotka & Anglie & Belgie & Francie & Německo & Rakousko \\
\hline Divise, & 3 brigaidy & 3 brigády & 2 brigády & 2 brigädy & 2 brigảdy \\
\hline Brigáda & 4 prapory & 2 pluky ") & 2 pluky & 2 pluky & 2 pluky \\
\hline Pluk & - & $\begin{array}{l}3 \text { prapory, } \\
1 \text { kulometná } \\
\text { rota }\end{array}$ & $\begin{array}{l}3 \text { prapory, } \\
1 \text { stabni rota } \\
\text { (tak zv. "com- } \\
\text { pagnie hors } \\
\text { rang") }\end{array}$ & $\begin{array}{l}3 \text { prapory. } \\
1 \text { kulometna } \\
\text { rota }\end{array}$ & $\begin{array}{l}\left.4 \text { prapory, }{ }^{* *}\right) \\
1 \text { techn. oddil } \\
\text { a telefonni četa }\end{array}$ \\
\hline Prapor & $\begin{array}{l}4 \text { roty, } \\
2 \text { kulomety }\end{array}$ & 4 roty & $\begin{array}{l}4 \text { roty, } \\
2 \text { kulomety }\end{array}$ & 4 roty & $\begin{array}{l}4 \text { roty. } \\
2 \text { kulomety }\end{array}$ \\
\hline Rota & 4 cety & 3 čety & 4 čety & 3 čety & 4 čety \\
\hline
\end{tabular}

*) Druhý pluk byl zřizen teprve pr̆i mobilisaci.

", Do tak zv. „compagnie hors rang" zařadẻni byli všichni, kter̆i nekonali službu v rotảch, jako telefonisté, pisaři, cyklisté, úč́etni atd.

**) Nëkteré pluky mély pouze tr̉i prapory. 
B. Organisace pẻchoty na konci vajlky r. 1918.

\begin{tabular}{|c|c|c|c|c|c|}
\hline Jednotka & Anglie & Belgie & Francie & Némecko & Rakousko \\
\hline Divise & $\begin{array}{l}3 \text { brigảdy. } \\
1 \text { kulometna } \\
\text { rota }\end{array}$ & 3 pluky & 3 pluky & 1 brigada & $\begin{array}{c}2 \text { brigády, } \\
1 \text { útočny oddil, } \\
1 \text { kulometný } \\
\text { ostrostrelecký } \\
\text { prapor }\end{array}$ \\
\hline Brigáda & $\begin{array}{l}4 \text { prapory, } \\
1 \text { kulomet. rota, } \\
1 \text { baterie vrhaču } \\
\text { granátú }\end{array}$ & - & - & 3 pluky & 2 pluky \\
\hline Pluk & , & 3 prapory & $\begin{array}{l}3 \text { prapory, } \\
1 \text { štábni rota } \\
\text { (t. zv. "com- } \\
\text { pagnie hors } \\
\text { rang") }\end{array}$ & $\begin{array}{c}3 \text { prapory, } \\
1 \text { vy̌zedny } \\
\text { oddil. } \\
1 \text { rota minometú }\end{array}$ & $\begin{array}{l}3 \text { prapory, } \\
1 \text { technická rota, } \\
1 \text { telefonni ćeta, } \\
1 \text { četa péchot- } \\
\text { nich dél }\end{array}$ \\
\hline Prapor & $\begin{array}{l}4 \text { roty, } \\
8 \text { lehkých stroj- } \\
\text { nich pušek }\end{array}$ & $\begin{array}{l}3 \text { rotv, } \\
1 \text { kulomet. rota }\end{array}$ & $\begin{array}{l}3 \text { roty. } \\
1 \text { kulomet. rota } \\
(137 \mathrm{~mm})\end{array}$ & $\begin{array}{l}4 \text { roty, } \\
1 \text { kulomet. rota }\end{array}$ & $\begin{array}{l}4 \text { roty. } \\
1 \text { kulomet. rota }\end{array}$ \\
\hline Rota & 4 čety & $\begin{array}{c}3 \text { čety, } \\
3 \text { lehké kulo- } \\
\text { mety pro každou } \\
\text { četu }\end{array}$ & $\begin{array}{c}4 \text { čety, } \\
4 \text { lehké kulo- } \\
\text { mety pro każdou } \\
\text { ćetu }\end{array}$ & $\begin{array}{c}3 \text { ćety, } \\
2(3, \text { lehké kulo- } \\
\text { mety pro każdou } \\
\text { cetu }\end{array}$ & $\begin{array}{l}3 \text { čety. } \\
1 \text { lehkỳ kulo- } \\
\text { metny oddil } \\
(4 \text { kulomety })\end{array}$ \\
\hline
\end{tabular}

Švédská armáda pořảala ve dnech 26. zár̈i až 3, ñjna t, r. velké krâlovské manevry. Manevrú účastnil se čturtý armádni sbor (Stokholm) a čisti prvniho, druhého a pátého armádniho sboru. Manevry konaly se v okoli švédského pristavniho mésta Söderhamnu. Veleni převzal osobné švédský král. Jemu přiděleni byli: šéf gen, stábu gen. Tingsten. Za velitele armaid byli ustanoveni: gen. insp. pěchoty Bergström a inspektor vojenských škol gen. Hodengren.

\section{Ztráty německé armády ve světovè válce.}

"Militär-Wochenblatt" ze dne 28, srpna t. $r$. sdēluje, že podle nejnovéjšich úrednich ztrát jevi se ztráty něrneckẻ armády ve svétové vảlce takto:

Pozemni vojsko ............. 1.718.608 mužĭ

Námornictvo .................. 24.726

$\mathrm{K}$ tomuto pristupuji nejpravdè̀podobnèji nezvěstni 5,007

Činil by tedy ủhrnnỷ poéet ztrát. .

\section{Sila armády Spojených států severoamerických.}

Podle úřednich zpráv bylo dne 15. července 1920 u pravidelné americké armády zařaděno 15.594 dủstojnikú a 192.475 mužủ, tedy celkem 208.069 hlav. Z toho nacházcio se ye Spojených státech severoamerických 158.449 mužủ, na ostrovech Filipinských 19.842 mužũ, v Némecku 16.128 mužủ, na Panamské šiji 4.663 mužủ, na Havajských ostrovech 4.641 mužủ. na ostrově Porto Rico 1.496 mužủ, v Ćiné 1.343 mužủ, na Aljašce 875 mužu, ve Francii 142 mužú, v Anglii 13 mužủ, ostatni na cesté do vlasti. Stav národni gardy činil dne 30. června 50.710 hlav. (Srovn. .Army and Navy Journal" ze dne 24. a 31. cervence 1920.) 


\section{Sila bojujicich armád ve svétové válce.}

Ve své knize „Die oberste Heeresleitung 1914-1916" *) podává némecký generál v. Falkenhayn prehled o sile bojujicich armád ve světové válce až do roku 1916 . Jsou to dosud prvni známé údaje o bojujicich armádách. Upozorñujeme, že $v$ tomto přehledu započitány jsou pouze ty vojenské jednotky, které se skutečné bojủ účastnily. Na oddily konajici službu $v$ etapách a ve vnitrozemi nebylo vzato žretele.

\section{A. Záp a dni bojiště.}

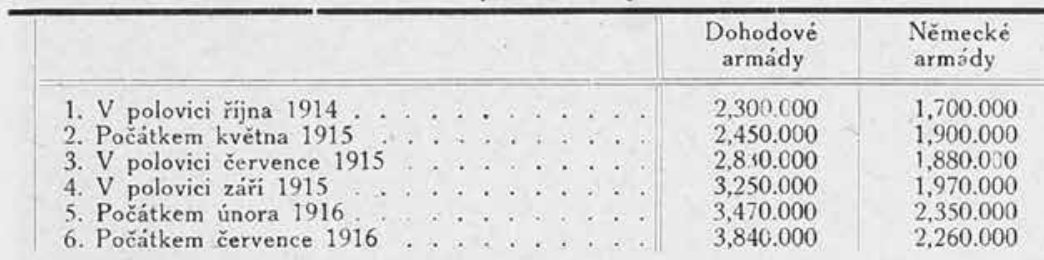

B. Východni bojiště.

\begin{tabular}{|c|c|c|c|c|c|}
\hline 2 & & $\begin{array}{l}\text { Ruská } \\
\text { vojska }\end{array}$ & $\begin{array}{c}\text { Německá } \\
\text { vojska }\end{array}$ & $\begin{array}{l}\text { Kakousko- } \\
\text { uherska } \\
\text { vojska }\end{array}$ & $\begin{array}{l}\text { Celkem nèm. } \\
\text { a raki-uh. } \\
\text { vojska }\end{array}$ \\
\hline$\stackrel{1}{\text { V pol. }}$ & $\begin{array}{l}\text { a) na hranicich vých. Pruska... } \\
\text { b) na polsko-nemeckých hranicich } \\
\text { a v Polsku . . . . . . . . . } \\
\text { c) v Haliči . . . }\end{array}$ & $\begin{array}{l}160.600 \\
133000 \\
652.000\end{array}$ & $\begin{array}{l}140.000 \\
40.000 \\
16.000\end{array}$ & $\begin{array}{c}- \\
- \\
367.000\end{array}$ & $\begin{array}{r}140.000 \\
40.000 \\
383.000\end{array}$ \\
\hline $\begin{array}{c}2 . \\
\text { Koncem } \\
\text { prosince } \\
1914\end{array}$ & $\begin{array}{l}\text { a) na nèmecké hranici (na pravèm } \\
\text { brehu Visly) } \\
\text { b) volsku a nu levém brehu } \\
\text { Visly . . . . . . } \\
\text { c) v Haliči a Bukovinè ..... }\end{array}$ & $\begin{array}{l}321.000 \\
847.000 \\
521.000\end{array}$ & $\begin{array}{r}105.000 \\
385000 \\
12.000\end{array}$ & $\begin{array}{c}- \\
140.000 \\
513.000\end{array}$ & $\begin{array}{l}105.000 \\
525.000 \\
525.000\end{array}$ \\
\hline $\begin{array}{l}3 . \\
\text { Koncem } \\
\text { ledna } \\
1915\end{array}$ & $\begin{array}{l}\text { a) na německé hranici (na pravém } \\
\text { břehu Visly). } \\
\text { b) v Polsku a na levém brehu } \\
\text { Visly } \\
\text { c) v Hałič a Bukovinè }\end{array}$ & $\begin{array}{l}317.000 \\
916.000 \\
610.000\end{array}$ & $\begin{array}{r}125.000 \\
273.000 \\
48000\end{array}$ & $\begin{array}{l}146.000 \\
525.000\end{array}$ & $\begin{array}{l}125.000 \\
419.000 \\
573.000\end{array}$ \\
\hline $\begin{array}{c}4 . \\
\text { Koncem } \\
\text { dubna } \\
1915\end{array}$ & $\begin{array}{l}\text { a) na némecké hranici (na pravém } \\
\text { brehu Visly) } \\
\text { b) v Polsku a na levém brehu } \\
\text { Visly } \\
\text { c) v Haliči a Bukoviné }\end{array}$ & $\begin{array}{l}640.000 \\
407.000 \\
720.000\end{array}$ & $\begin{array}{r}366.000 \\
184.000 \\
89.000\end{array}$ & $\begin{array}{r}54.000 \\
610.000\end{array}$ & $\begin{array}{l}360.000 \\
238.000 \\
699.000\end{array}$ \\
\hline $\begin{array}{l}\text { 5. Poc̀at- } \\
\text { kem cervna } \\
1916\end{array}$ & $\begin{array}{l}\text { a) severné reky Pripet } \ldots . \\
\text { b) jižně reky Pripef . . . . }\end{array}$ & $\begin{array}{r}1,593.000 \\
650.000\end{array}$ & $\begin{array}{r}560.000 \\
30.000\end{array}$ & $\begin{array}{r}30.000 \\
456.000\end{array}$ & $\begin{array}{l}590.000 \\
486.000\end{array}$ \\
\hline
\end{tabular}

\section{Poučeni o pohlavnich chorobách.}

Ministerstva ver̉ejného zdravotnictvi a tělesné vỷchovy s ministerstvem školstvi a národni osvěty vydalo leták takto nazvaný, aby mladi lidé, škole odrostli, byli poučeni o pohlavnich chorobách a aby poučeni to stalo se ve smyslu myšlenek uvedených v tomto letáku. Po statistickém úvodu jsou stručně probrány následky pohlavnich chorob a za nejlepši ochranu proti nim doporučuje se pohlavni zdrželivost, kterou lze nejlépe prováděti pri abstinenci lihových nápojủ a pěstováni sportu.

Doporučujeme vřele tento leták jednotlivým voj. oddilủm a zvláště voj. osvětovým referentủm, jichž úkolem bude, aby $\mathrm{i} v$ tomto směru byli nováčkové ruádně a včas poučeni. Leták jest na skladé ve státnim školnim knihoskladẽ v Praze.

*) v. F alkenhayn: „Die oberste Heeresleitung 1914-16“, Berlin 1920, E. S. Mittler \& Sohn. 


\section{OBSAH}

Přistěhovalectví ve Francii a jeho bezpečnostní dopady

Jan Eichler

Obranné strategie malých států NATO - komparativní studie

Lukáš Dyčka, Taivo Rõkk, Zdzisław Śliwa

Analýza dynamiky konfliktu v Mali - využití databáze ACLED

Jan Kofroň, Michal Opletal, Matyáš Zrno

Stanovování a hodnocení kompetencí důstojníka ozbrojených

sil České republiky.

Jaroslav Kuba, Richard Saibert

\section{PŘíLOHY}

Střelba s jednotným dopadem střel a možnosti využití

v Armádě České republiky

Michal Šustr, Ladislav Potužák, Martin Blaha, Jan Ivan

Informační systém tělesné přípravy Armády České republiky

Petr Hanák, Jiři Sekanina, Tomáš Ráčil

Společná bezpečnostní a obranná politika EU v kostce - část druhá

Vilém Kolín

Otiskli jsme před 100 lety

Redakce 


\section{CONTENTS}

Immigration in France and its security consequences

Jan Eichler

Defence strategies of the smaller NATO states - a comparative study

Lukáš Dyčka, Taivo Rõkk, Zdzisław Śliwa

Analysis of the Malian conflict dynamics - exploiting ACLED database

Jan Kofroň, Michal Opletal, Matyáš Zrno

Defining and Evaluation of Competencies of an Officer

of the Czech Armed Forces

Jaroslav Kuba, Richard Saibert

\section{ENCLOSURE}

Multiple round simultaneous impact fires and possibilities of its application in Czech Army

Michal Šustr, Ladislav Potužák, Martin Blaha, Jan Ivan

Physical Training Information System of the Armed Forces of the Czech Republic

Petr Hanák, Jiři Sekanina, Tomáš Ráčil

EU's Common Security and Defence Policy in a Nutshell - Part Two

Vilém Kolín

Printed 100 years ago

Editorial Staff 
Časopis VOJENSKÉ ROZHLEDY

čtvrtletník

Vydává:

Ministerstvo obrany České republiky, Tychonova 1, 16001 Praha 6 - Dejvice

Vydávající instituce:

Univerzita obrany v Brně, Kounicova 156/65, 66210 Brno

IČO: 60162694

Vojenské rozhledy č. 4/2020

Ročník: XXIX. (LXI.)

Datum předání do tisku: 24. listopadu 2020

Rozšiřuje:

OKP MO, distribuce, Rooseveltova 23, 16105 Praha 6

Olga Endlová, tel. 973215 563, endlovao@army.cz

Redakce: Ing. Petr Koziel, telefon: 973443499

E-mail: vojenskerozhledy@unob.cz

Redakční rada: Ing. Ján Spišák, Ph.D. (předseda), PhDr. Miloš Balabán, Ph.D., pplk. Marco Biagini, Ph.D., prof. Mgr. Oldřich Bureš, Ph.D., M. A., doc. PhDr. Felix Černoch, CSc., plk. Florian Cîrciumaru, Ph.D., Mgr. Lukáš Dyčka, Ph.D., doc. PhDr. Jan Eichler, CSc., Mgr. et. Mgr. Jakub Fučík, Ph.D., prof. Dr. hab. Artur Gruszczak, plk. gšt. doc. Ing. Vladan Holcner, Ph.D., Ing. Vladimír Karaffa, CSc., prof. Ing. Aleš Komár, CSc., PhDr. Tomáš Kopečný, Mgr. Josef Kraus, Ph.D., brig. gen. Ing. Miloslav Lafek, prof. Juha-Matti Lehtonen, Ph.D., plk. gšt. Ing. Tomáš Novotný, Ph.D. MSc., Mgr. Martin Riegl, Ph.D., plk. Chris Rogers, MA, MMAS., doc. Hofrat Univ. Dr. Erwin Schmidl, Ph.D., Dr. hab. Zdzislaw Sliwa, RNDr. Pavel Štalmach, MBA, Ing. Miroslav Šuhaj, Ph.D., Mgr. et Mgr. Lukáš Tichý, Ph.D.

Tajemník redakční rady: Ing. Petr Koziel

Sídlo redakce: Kounicova 65, 66210 Brno

Adresa pro zasílání pošty: Vojenské rozhledy - redakce, Kounicova 156/65, 66210 Brno

Časopis Vojenské rozhledy v elektronické podobě naleznete na:

http://www.vojenskerozhledy.cz/

Časopis je evidován:

- v evropské databázi ERIH PLUS,

- $v$ seznamu recenzovaných neimpaktovaných periodik vydávaných v České republice

- v mezinárodní databázi Index Copernicus Journals Master List 2015

- v katalogu Národní knihovny České republiky

- $v$ databázi Central and Eastern European Online Library GmbH (CEEOL)

- v databázi Directory of Open Access Journals (DOAJ)

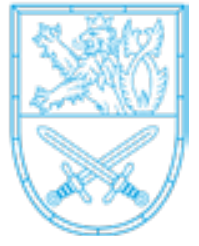

Grafická úprava: Adéla Zemanová

Tiskne: VGHMÚř Dobruška

Evidenční číslo: MK ČR E 6059

Identifikační číslo: ISSN 1210-3292 (print), ISSN 2336-2995 (on-line)

doi: 10.3849/2336-2995 